\title{
Bechtel Nevada
}

\section{Composite Analysis for the Area 5 Radioactive Waste Management Site at the Nevada Test Site, Nye County, Nevada}

September 2001

\author{
Prepared by
}

Bechtel Nevada

Prepared for

U.S. Department of Energy

National Nuclear Security Administration

Nevada Operations Office under Contract Number

DE-AC08-96NV11718 
Reference herein to any specific commercial product, process, or service by trade name, trademark, manufacturer, or otherwise does not necessarily constitute or imply its endorsement, recommendation, or favoring by the United States Government or any agency thereof or its contractors or subcontractors.

Available for sale to the public from:

U.S. Department of Commerce

National Technical Information Service

5285 Port Royal Road

Springfield, VA 22161

Phone: 800.553 .6847

Fax: 703.605.6900

Email: orders@ntis.fedworld.gov

Online ordering: http://www.ntis.gov/ordering.htm

Available electronically at http://www.doe.gov.bridge

Available for a processing fee to U.S. Department of Energy and its contractors, in paper, from:

U.S. Department of Energy

Office of Scientific and Technical Information

P.O. Box 62

Oak Ridge, TN 37831-0062

Phone: 865.576 .8401

Fax: 865.576 .5728

E-mail: reports@adonis.osti.gov 


\section{Bechtel Nevada}

\section{Composite Analysis for the Area 5 Radioactive Waste Management Site at the Nevada Test Site, Nye County, Nevada}

September 2001

Prepared by

Bechtel Nevada

Prepared for

U.S. Department of Energy

National Nuclear Security Administration

Nevada Operations Office under Contract Number

DE-AC08-96NV11718 
This Page Intentionally Left Blank 


\section{CONTENTS}

ACRONYMS and ABBREVIATIONS $\ldots \ldots \ldots \ldots \ldots \ldots \ldots \ldots \ldots \ldots \ldots \ldots \ldots \ldots$

EXECUTIVE SUMMARY $\ldots \ldots \ldots \ldots \ldots \ldots \ldots \ldots \ldots \ldots \ldots \ldots \ldots \ldots \ldots$

1.0 INTRODUCTION $\ldots \ldots \ldots \ldots \ldots \ldots \ldots \ldots \ldots \ldots \ldots \ldots \ldots \ldots \ldots \ldots$

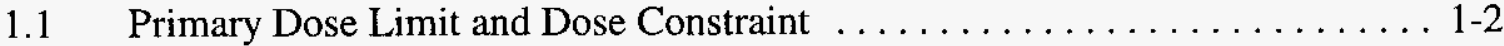

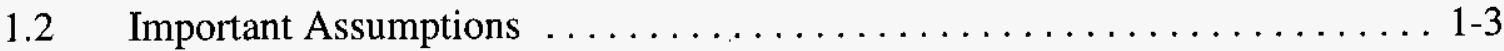

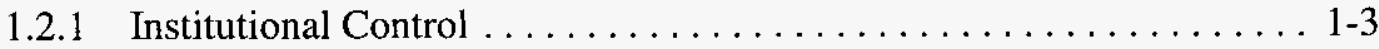

1.2.2 Compliance Period . . . . . . . . . . . . . . . . . . . 1-4

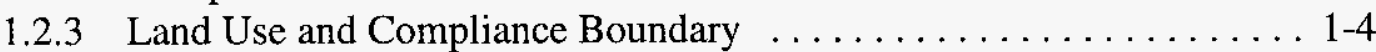

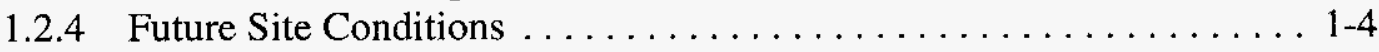

1.2.5 Performance of the Engineered Closure Cap $\ldots \ldots \ldots \ldots \ldots \ldots$ 1-5

2.0 OVERVIEW OF THE AREA 5 RWMS AND ENVIRONS $\ldots \ldots \ldots \ldots \ldots \ldots \ldots$ 2-1

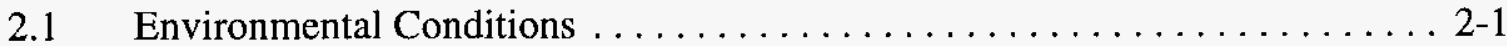

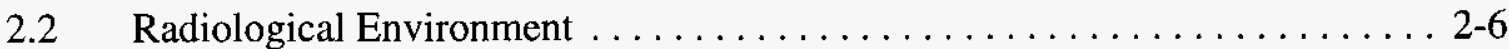

2.3 Area 5 Radioactive Waste Management Site Description . . . . . . . . . . 2-13

2.3.1 Land Burial Operations in Pits and Trenches $\ldots \ldots \ldots \ldots \ldots \ldots$ 2-16

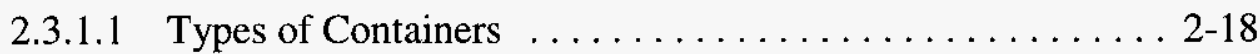

2.3.1.2 Placement of Containers . . . . . . . . . . . . . 2-19

2.3.2 Temporary Closure Cap for Pits and Trenches . . . . . . . . . . . 2-19

2.3.3 Mixed Waste Disposal . . . . . . . . . . . . . . . . . 2-20

2.3.4 Greater Confinement Disposal . . . . . . . . . . . . . . . . 2-20

3.0 DATA QUALITY OBJECTIVES $\ldots \ldots \ldots \ldots \ldots \ldots \ldots \ldots \ldots \ldots \ldots \ldots \ldots$

3.1 Results of Data Quality Objectives Process ................. 3-2

3.1.1 Step 1: Statement of the Problem .................. 3-2

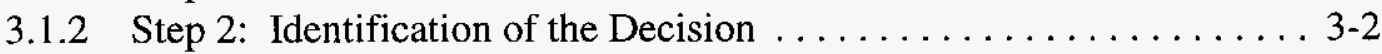

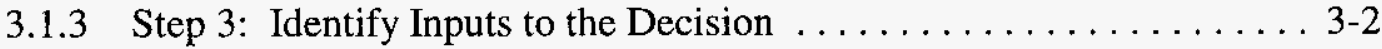

3.1.3.1 Regulatory Drivers $\ldots \ldots \ldots \ldots \ldots \ldots \ldots \ldots \ldots \ldots \ldots \ldots$

3.1.3.2 Waste Management Projects . . . . . . . . . . . . . 3-4

3.1.3.3 Environmental Restoration Program ... . . . . . . 3-6

3.1.3.4 Environmental Monitoring $\ldots \ldots \ldots \ldots \ldots \ldots \ldots \ldots \ldots \ldots$

3.1.3.5 Resource Management . . . . . . . . . . . . . . . 3-9 


\section{CONTENTS}

3.1.4 Step 4: Definition of the Study Boundaries . . . . . . . . . . . 3-9

3.1.5 Step 5: Develop a Decision Rule ................. 3-10

4.0 RADIONUCLIDE INVENTORIES $\ldots \ldots \ldots \ldots \ldots \ldots \ldots \ldots \ldots \ldots \ldots \ldots$

4.1 Estimated Inventory of the Area 5 RWMS at Closure ........... 4-1

4.1.1 Screening Analysis for the Release of Nonvolatile

Radionuclides from the Area 5 RWMS Shallow

Pits and Trenches ..........................44-3

4.2 Estimated Inventory of Contaminated Soil Corrective Action Units . . . . . 4-3

4.2.1 Screening Analyses of Radionuclide Emissions From

Contaminated Soil Corrective Action Units $\ldots \ldots \ldots \ldots \ldots . . .4-5$

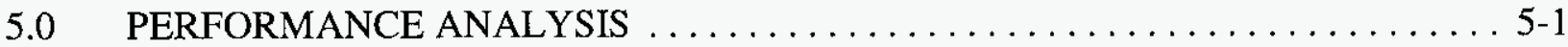

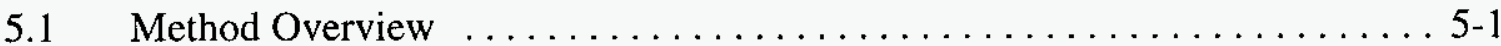

5.2 Source Term Conceptual Models . . . . . . . . . . . . . . . . . 5-2

5.2.1 Contaminated Soil Corrective Action Unit Source Term

Conceptual Model . . . . . . . . . . . . . . . . . . 5-2

5.2.2 The Area 5 Radioactive Waste Management Site Source

Conceptual Model . . . . . . . . . . . . . . . . . . 5-2

5.2.2.1 Shallow Pits and Trenches Source $\ldots \ldots \ldots \ldots \ldots \ldots$. . 2

5.2.2.2 Lower Cell of Pit 6 (P06U) . . . . . . . . . . . . . . 5-3

5.2.2.3 Greater Confinement Disposal and Greater Confinement

Disposal Test ..................... 5-5

5.3 Conceptual Models of Transport $\ldots \ldots \ldots \ldots \ldots \ldots \ldots \ldots \ldots \ldots \ldots \ldots$

5.3.1 Transport Models for the Shallow Pits and Trenches at the

Area 5 RWMS ....................... 5-5

5.3.1.1 Nonvolatile Radionuclides . . . . . . . . . . . . . 5-5

5.3.1.2 Volatile Radionuclides . . . . . . . . . . . . . . . . . . 5-7

5.3.2 Off-Site Dispersion of Volatile and Nonvolatile Radionuclides . . . . 5-8

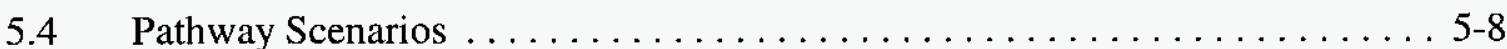




\section{CONTENTS}

$6.0 \quad$ RESULTS OF ANALYSES $\ldots \ldots \ldots \ldots \ldots \ldots \ldots \ldots \ldots \ldots \ldots \ldots \ldots \ldots \ldots \ldots \ldots$

6.1 Results for the Area 5 Radioactive Waste Management Site $\ldots \ldots \ldots \ldots \ldots$. . . .

6.1 .1 Nonvolatile Radionuclides . . . . . . . . . . . . . . . . 6-1

6.1 .2 Volatile Radionuclides . . . . . . . . . . . . . . . . . . . 6-4

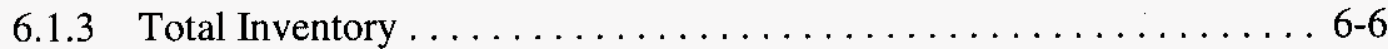

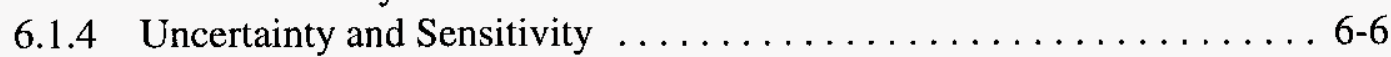

6.2 Results for Contaminated Soil Corrective Action Units $\ldots \ldots \ldots \ldots \ldots \ldots$. 6-8

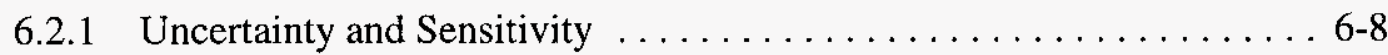

6.3 Results for Areas Not Within Contaminated Soil Sites . . . . . . . . . 6-12

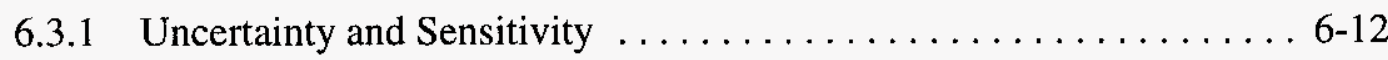

7.0 INTERPRETATION OF RESULTS $\ldots \ldots \ldots \ldots \ldots \ldots \ldots \ldots \ldots \ldots \ldots$

7.1 Total Effective Dose Equivalent From Interacting Sources $\ldots \ldots \ldots \ldots \ldots$. $\ldots$

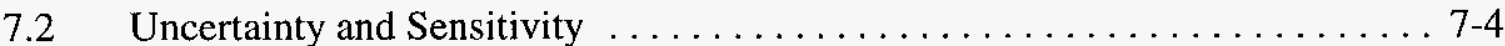

7.2.1 Land-Use Boundaries . . . . . . . . . . . . . . . . . . . . 7-4

7.2.2 Final Closure of the Area 5 Radioactive Waste Management Site . . . 7-4

7.2.3 Remediation and Closure of the Gadgets, Mechanics, and Explosives Soil Site . . . . . . . . . . . . . . . . . . . . 7-5

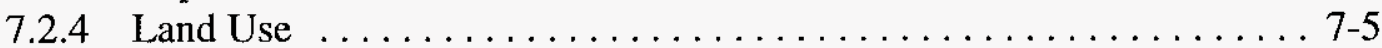

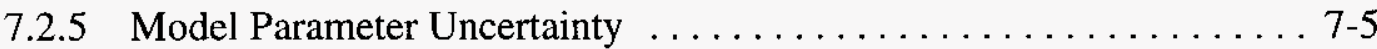

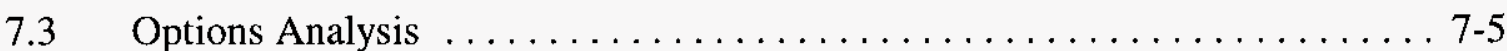

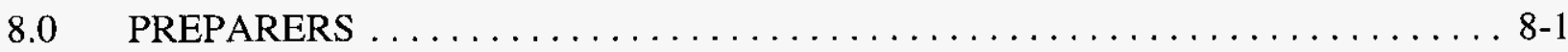

$8.1 \quad$ Principal Investigators $\ldots \ldots \ldots \ldots \ldots \ldots \ldots \ldots \ldots \ldots \ldots \ldots \ldots \ldots$

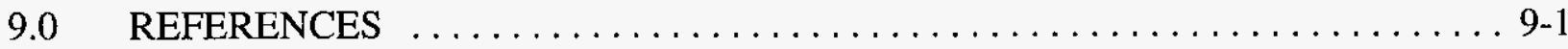

Appendix 1 Composite Analysis Inventory

Appendix 2 Release and Transport Models

Appendix 3 Radiological Assessment Method 


\section{List of Figures}

2.1 Location of the Nevada Test Site Within the State of Nevada . . . . . . . . . 2-2

2.2 Location of the Area 5 Radioactive Waste Management Site on the Nevada

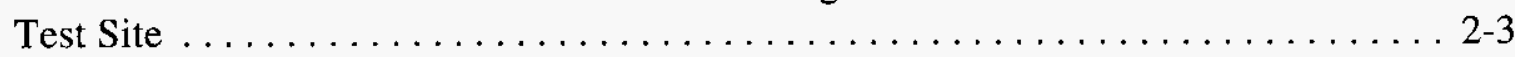

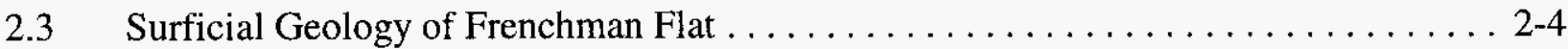

2.4 Hydrogeological Cross-Section of Frenchman Flat $\ldots \ldots \ldots \ldots \ldots \ldots \ldots \ldots \ldots$

2.5 Principal Groundwater Subbasins and Groundwater Flow Directions Near the

Nevada Test Site . . . . . . . . . . . . . . . . . . . 2.7

2.6 Weapons Tests Conducted at the Nevada Test Site (1951 to 1962) . . . . . . . . . 2-9

2.7 Location of Underground Testing Area Corrective Action Units on the Nevada

Test Site . . . . . . . . . . . .

2.8 Location of Contaminated Sites in Frenchman Flat Included in the Composite

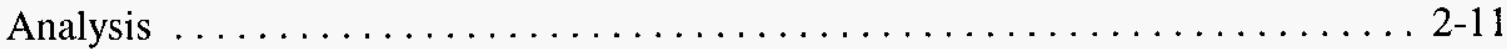

2.9 Layout of the Area 5 Radioactive Waste Management Site . . . . . . . . . . . 2-14

2.10 Locations of Disposal Units and Support Structures at the Area 5 Radioactive

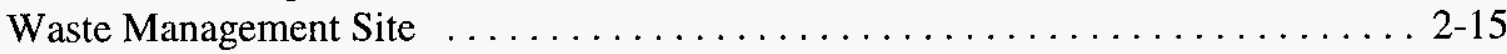

6.1 Mean Surface Soil Concentration as a Function of Time Since Closure for the Area 5 RWMS . . . . . . . . . . . . . .

6.2 Estimated Mean TEDE to a Resident Living at the Area 5 RWMS from the

Disposed Waste Inventory . . . . . . . . . . . . . . . . . $\ldots \ldots \ldots$

6.3 Cumulative Probability of 1,000 Monte Carlo Realizations of TEDE from

Nonvolatile Radionuclides for a Resident at the Area 5 RWMS, 1,000 Years

After Closure . . . . . . . . . . . . . . . . . . . . . . . . . .

6.4 Cumulative Probability of 1,000 Monte Carlo Realizations of TEDE from

Volatile Radionuclides for a Resident at the Area 5 RWMS, 100 and 250

Years After Closure . . . . . . . . . . . . . . . . . . . . . . . 6 6-9

6.5 Cumulative Probability of 10,000 Monte Carlo Realizations of TEDE at 1,000

Years for a Resident at the Frenchman Flat Playa and GMX Contaminated Soil

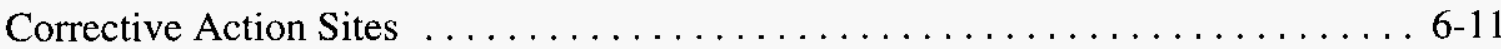

7.1 Mean Integrated Total Effective Dose Equivalent Estimated for Frenchman Flat

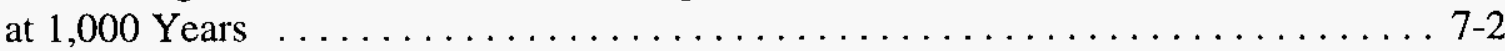

7.2 The 95th Percentile Integrated Total Effective Dose Equivalent Estimated for

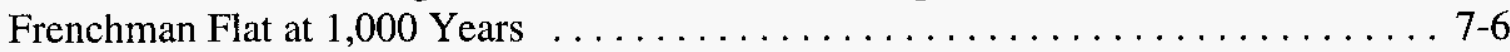

\section{List of Tables}

2.1 Underground Nuclear Tests in the Frenchman Flat $\ldots \ldots \ldots \ldots \ldots \ldots \ldots \ldots \ldots 2$

2.2 Operational Status and Dimensions of Shallow Pits and Trenches at the Area 5

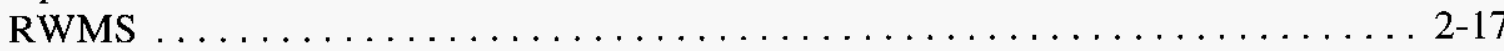

2.3 Operational Status of GCD Boreholes at the Area 5 RWMS $\ldots \ldots \ldots \ldots \ldots \ldots 2-18$

3.1 Regulatory Drivers for DOE Operations at the NTS . . . . . . . . . . . . 3-4

4.1 Estimated Inventory for the Area 5 RWMS GCD and GCDT Boreholes . . . . . . 4-3

4.2 Estimated Inventory of Shallow Pits and Trenches at the Area 5 RWMS at Closure in 2028 for Radionuclides Meeting the Screening Criteria . . . . . . . . . . . . 4-4 


\section{List of Tables}

4.3 Inventories in Curies and Area in Square Meters Estimated by the RIDP and NAEG for Important Contaminated Soil Corrective Action Units in Areas 5

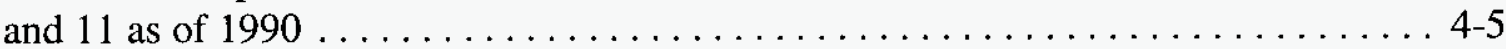

5.1 Estimated Upward Advection Flux and 1,000-Year Travel Length at the Area 5 Radioactive Waste Management Site Under Current Conditions. . . . . . . . . . . . 5-4

6.1 Mean and 95th Percentile TEDE for a Resident at the Area 5 RWMS . . . . . . . . . 6-4

6.2 Mean and 95th Percentile Nonvolatile Radionuclide Emissions Rates from the Area 5 RWMS at 1,000 Years After Closure . . . . . . . . . . . . . . . 6-5

6.3 Mean and 95th Percentile Volatile Radionuclide Emissions Rates from the Area 5 RWMS at 1,000 Years After Closure . . . . . . . . . . . . . . . . 6-5

6.4 Mean and 95th Percentile Total Effective Dose Equivalent to a Resident Living in the Frenchman Flat Playa Soil Site and the GMX Soil Site at 250 and 1,000 Years After Closure . . . . . . . . . . . . . . . . . . . . . 6-10

6.5 Radionuclide Emission Rates for the Frenchman Flat Playa Soil Site and the GMX Soil Site at 1,000 Years After Closure . . . . . . . . . . . . . . 6-10 


\section{ACRONYMS and ABBREVIATIONS}

$\begin{array}{ll}\text { ac } & \text { acre } \\ \text { ALARA } & \text { as low as reasonably achievable } \\ \text { ANSI } & \begin{array}{l}\text { American National Standards Institute } \\ \text { atm }\end{array} \\ & \text { Bechospheres } \\ \text { BN } & \text { Becquerel } \\ \text { Bq } & \\ \text { CA } & \text { composite analysis } \\ \text { CADD } & \text { Corrective Action Decision Document } \\ \text { CAI } & \text { corrective action investigation } \\ \text { CAS } & \text { corrective action site } \\ \text { CAU } & \text { corrective action unit } \\ \text { CEDE } & \text { committed effective dose equivalent } \\ \text { CFR } & \text { Code of Federal Regulations } \\ \text { Ci } & \text { Curie } \\ \text { cm } & \text { centimeter } \\ \text { d } & \text { day } \\ \text { DF } & \text { dose factor } \\ \text { DNFSB } & \text { Defense Nuclear Facility Safety Board } \\ \text { DOC } & \text { U.S. Department of Commerce } \\ \text { DoD } & \text { U.S. Department of Defense } \\ \text { DOE } & \text { U.S. Department of Energy } \\ \text { DOE/HQ } & \text { U.S. Department of Energy/Headquarters } \\ \text { DOE/NV } & \text { U.S. Department of Energy/Nevada Operations } \\ \text { DOT } & \text { U.S. Department of Transportation } \\ \text { DRI } & \text { Desert Research Institute } \\ \text { DU } & \text { depleted uranium } \\ \text { EM } & \text { Environmental Management } \\ \text { EPA } & \text { U.S. Environmental Protection Agency } \\ \text { ER } & \text { Environmental Restoration } \\ \text { FEMP } & \text { Fernald Environmental Management Project } \\ \text { FFACO } & \text { field instrument for the determination of low-energy radiation } \\ & \end{array}$




\section{Acronyms and Abbreviations}

\begin{tabular}{|c|c|}
\hline & gram \\
\hline GCD & Greater Confinement Disposal \\
\hline GCDT & Greater Confinement Disposal Test \\
\hline GMX & gadgets, mechanics, and explosives \\
\hline GZ & ground zero \\
\hline ISCLT & Industrial Source Code, Long-Term \\
\hline IT & International Technology Corporation \\
\hline HWSU & Hazardous Waste Storage Unit \\
\hline $\mathrm{K}$ & Kelvin \\
\hline $\mathrm{kg}$ & kilogram \\
\hline $\mathrm{km}$ & kilometer \\
\hline 1 & liter \\
\hline LLW & low-level radioactive waste \\
\hline LLWMU & Low-Level Radioactive Waste Management Unit \\
\hline LWIS & Low-Level Waste Information System \\
\hline $\mathrm{m}$ & meters \\
\hline $\mathrm{mCi}$ & millicurie \\
\hline MFP & mixed fission products \\
\hline $\mathrm{mi}$ & miles \\
\hline $\mathrm{ml}$ & millimeter \\
\hline mrem & millirem \\
\hline $\mathrm{mSv}$ & millisievert \\
\hline MW & mixed waste \\
\hline NAEG & Nevada Applied Ecology Group \\
\hline NDEP & Nevada Division of Environmental Protection \\
\hline NNSA & National Nuclear Security Administration \\
\hline $\mathrm{NRC}$ & U.S. Nuclear Regulatory Commission \\
\hline NRDS & Nuclear Rocket Development Station \\
\hline NTS & Nevada Test Site \\
\hline PA & performance assessment \\
\hline $\mathrm{pCi}$ & picocurie \\
\hline PDCF & pathway dose conversion factor \\
\hline RCRA & Resource Conservation and Recovery Act \\
\hline RIDP & Radionuclide Inventory and Distribution Program \\
\hline
\end{tabular}




\section{Acronyms and Abbreviations}

$\begin{array}{ll}\text { RWMS } & \begin{array}{l}\text { Radioactive Waste Management Site } \\ \text { RSL }\end{array} \\ \text { S } & \begin{array}{l}\text { Remote Sensing Laboratory } \\ \text { second }\end{array} \\ \text { SDCF } & \begin{array}{l}\text { scenario dose conversion factor } \\ \text { subject matter expert }\end{array} \\ \text { SME } & \text { Sievert } \\ \text { Sv } & \text { total effective dose equivalent } \\ \text { TEDE } & \text { transuranic waste } \\ \text { TRU } & \text { underground testing area } \\ \text { UGTA } & \text { Waste Examination Facility } \\ \text { WEF } & \text { Waste Management Data Base } \\ \text { WMDB } & \text { waste storage pad } \\ \text { WSP } & \\ \text { yr } & \text { year } \\ \mu C i & \text { microcurie }\end{array}$




\section{EXECUTIVE SUMMARY}

\section{Background}

This report summarizes the results of a Composite Analysis (CA) for the Area 5 Radioactive Waste Management Site (RWMS). The Area 5 RWMS is a U.S. Department of Energy (DOE)operated low-level radioactive waste (LLW) management site located in northern Frenchman Flat on the Nevada Test Site (NTS). The Area 5 RWMS has disposed of low-level radioactive waste in shallow unlined pits and trenches since 1960. Transuranic waste (TRU) and high-specific activity waste was disposed in Greater Confinement Disposal (GCD) boreholes from 1983 to 1989.

In the future, members of the public residing near DOE LLW disposal sites may receive a radiological dose from all sources of radioactive materials remaining in the environment. In 1995, the DOE requested that all LLW disposal site operators prepare an integrated radiological assessment, known as a CA, that would assess the combined radiological hazards posed by LLW disposal sites and all radioactive sources interacting with LLW disposal sites (DOE, 1995a,b). DOE committed to preparing CAs in response to Defense Nuclear Facilities Safety Board (DNFSB) Recommendation 94-2 (DOE, 1995b). Completion and approval of a CA is one of several requirements that must be met to receive a Disposal Authorization Statement (DAS) from the DOE for operation of a LLW disposal site. Other requirements are completion and approval of a Performance Assessment (PA), and submission of a PA/CA maintenance plan, a closure plan, and a monitoring plan.

The purpose of this CA is to determine if continuing operation of the Area 5 RWMS poses an acceptable or unacceptable risk to the public considering the total waste inventory and all other interacting sources of radioactive material in the vicinity. Continuing operation of the Area 5 RWMS will be considered acceptable if the total effective dose equivalent (TEDE) is less than 100 mrem in a year. If the TEDE exceeds 30 mrem in a year, a cost-benefit options analysis must be performed to determine if cost-effective management options exist to reduce the dose further. If the TEDE is found to be less than $30 \mathrm{mrem}$ in a year, an analysis may be performed if warranted to determine if doses are as low as reasonably achievable (ALARA).

The CA is complementary to the Performance Assessment for the Area 5 Radioactive Waste Management Site at the Nevada Test Site, Nye County Nevada, Revision 2.1 (Shott et al., 1997a). The Area 5 Performance Assessment (PA) assesses the risks posed to the public and the environment from the radioactive constituents in LLW and mixed waste regulated under DOE Order 5820.2A, "Radioactive Waste Management" (DOE, 1988). Waste regulated under DOE Order 5820.2A (DOE, 1988) includes radioactive waste disposed from the Order's implementation date on September 26, 1988, to the projected date of site closure. 


\section{Site Description}

The Area 5 RWMS is sited in Frenchman Flat, an arid alluvium-filled intermontane basin typical of the Basin and Range Physiographic Province. The average annual precipitation is only 12 centimeters (cm) (4.7 inches [in]) per year. The annual potential evapotranspiration is estimated to be approximately 14 times greater than precipitation. Chloride and stable isotope profiles indicate that infiltrating precipitation is returned to the atmosphere by evapotranspiration before reaching a depth of 10 meters $(\mathrm{m})$ (33 feet [ft]). Chloride age dating indicates that infiltration below $10 \mathrm{~m}(33 \mathrm{ft})$ ceased 20,000 to 30,000 years ago. The uppermost aquifer occurs $240 \mathrm{~m}$ (790 ft) beneath the site within the alluvium. Under current climatic conditions, transport of radioactive materials from near-surface soils to the uppermost aquifer is not expected to occur.

The Area 5 RWMS began disposing LLW generated on the NTS in 1960. In 1978, operations were expanded to include disposal of LLW generated by off-site DOE generators. To date, LLW has been disposed in 22 shallow pits and trenches and mixed waste in a single pit (P03U). TRU was inadvertently disposed in a single trench (T04C). Full disposal units are covered with a $2.4 \mathrm{~m}(8 \mathrm{ft})$ operational cover pending final closure of the entire site. From 1983 to 1989, TRU and high-specific-activity waste was disposed in nine 36-meter (120 ft) deep GCD boreholes.

The Area 5 RWMS PA demonstrated that the doses expected from operation of the Area 5 RWMS are low for hypothetical future residents of Frenchman Flat and negligible for residents at more distant locations. Therefore, radioactive sources considered in the CA are limited to those which could contribute to the dose of a future resident living in Frenchman Flat.

DOE operations that have left residual radioactive material in Frenchman Flat and its environs are atmospheric nuclear testing, underground nuclear testing, nonnuclear destruction of nuclear weapons for safety or design studies, and waste disposal. Historically contaminated sites on the NTS have been categorized into corrective action units (CAUs) that may contain several smaller corrective action sites (CASs). Nine sources of radioactive material, categorized as either underground testing areas (UGTAs) or contaminated soil sites, have a potential to interact with the Area 5 RWMS because of their proximity. Ten underground tests conducted within Frenchman Flat are combined into the Frenchman Flat UGTA (CAU 98). The contaminated soil sites include the Frenchman Flat playa soil site (CAU 106); the Gadgets, Mechanics, and Explosives (GMX) soil site (CAU 365); the Plutonium Valley soil site (CAU 366); the 306 soil site (CAU 999, CAS 05-45-07), the 307 soil site (CAU 999, CAS 05-45-05); the Kay Block House (CAU 204, CAS 05-33-01); the Gravel Gertie (CAU 140, CAS 05-23-01); and the PIN STRIPE soil site (CAU 98; 11-57-001). Four sites, the 306 and 307 soil sites, the Kay Block House, and the Gravel Gertie, were excluded because of their small inventories, small size, and distance from the Area 5 RWMS. The PIN STRIPE soil site was excluded because its small fission product and activation product inventory will decay to negligible levels during institutional control of the NTS. The Plutonium Valley soil site was excluded because a comparison of modeling and environmental monitoring results suggests that the intervening $1,400-$ to $1,600-\mathrm{m}$ (4,500- to 5,200-ft) mountain ridges are an effective barrier to atmospheric transport.

The sources retained for the CA were the Area 5 RWMS, the Frenchman Flat UGTA, the Frenchman Flat playa soil site, and the GMX soil site. The Frenchman Flat playa soil site is a 
contaminated soil site created by atmospheric nuclear weapons tests. The GMX soil site is a plutonium-contaminated soil site created by nonnuclear detonations of nuclear weapon components.

\section{Future Land Use}

The primary national security mission of the NTS is to preserve the capability to resume underground nuclear testing, perform subcritical and other weapons physics experiments, and perform national security related experiments for other defense organizations. Public access to the NTS is currently restricted and will continue to be restricted as long as the NTS has an active national security mission. If the NTS national security mission ends, the release of NTS land for public access will be constrained by historical contamination from atmospheric nuclear testing, underground nuclear testing, nuclear rocket testing, and radioactive waste disposal. Remediation and closure of historically contaminated sites on the NTS is regulated by the Federal Facilities Agreement and Consent Order (FFACO) between the NNSA/NV, state of Nevada, and the U.S. Department of Defense. The FFACO defines a Resource Conservation and Recovery (RCRA)like process for remediation and closure of CAUs and requires state of Nevada review and approval of all corrective actions. Release of land for public access is also subject to the requirements of DOE Order 5400.5 (DOE, 1990).

A panel of independent subject matter experts (SMEs) has evaluated the effectiveness and probable duration of long-term institutional controls in Frenchman Flat through formal elicitation (Black et al., 1998). Elicitation was used to assess quantile values from the SMEs using standard methods of expert judgement. The SME consensus opinion supports the conclusion that there is a 50 percent probability that active institutional controls will continue for up to 250 years in Frenchman Flat. The basis of the SME opinion lay primarily in the integrity of the oral record and physical evidence of long-term, widespread underground nuclear testing (i.e., radiological contamination, surface subsidence craters, and structural remnants). Therefore, the CA assumes that active institutional controls will be effective for 250 years after closure.

The /NV has implemented the UGTA Program and the Soils Program to close the UGTAs and contaminated soil sites under the FFACO. Remediation of the UGTAs is unlikely to be costeffective because of the volume of contaminated soil and great depth of the contamination. Therefore, the present objective of the UGTA Program is to develop CAU groundwater models that will be used to identify and establish a land-use boundary where access or groundwater use and subsurface intrusion will be restricted. The UGTA contaminant boundaries will correspond with a median dose of 4-mrem in a year dose from groundwater use over a 1,000-year period. The UGTA Program has completed a preliminary CAU model for Frenchman Flat using existing data and submitted the model and its results to external peer review. The peer reviewers concluded that the model results were unreliable because of large uncertainty in the UGTA source inventory, radionuclide release rates from the rock matrix, site hydrostratigraphy, groundwater flow direction and flow rates, and transport parameters (IT, 1999). The UGTA Program is currently developing new site characterization data for Frenchman Flat, which will be used to develop a new CAU model. Because of the current lack of site-specific data, the dose from the Frenchman Flat UGTA cannot be estimated and the location of future land-use boundaries cannot 
be determined. In addition, the Soils Program has not developed final plans for the remediation and closure of the contaminated soil sites in Frenchman Flat. Therefore, the CA assumes that these sites are not remediated.

\section{Conceptual Models}

The CA assumes that waste disposal operations at the Area 5 RWMS will cease in 2028 when final closure will occur. The site is assumed to be closed with a thick, 2- to 6-m (6- to 20-ft) mono-layer alluvium cap. Closure is assumed to be followed by a 250 -year period of active institutional control. The closure cap is assumed to be actively maintained for the first 100 years after closure. Maintenance is assumed to repair subsidence and remove vegetation from the cap. Subsidence of steel containers is assumed to continue beyond the 100 -year maintenance period. Subsidence of the cap is assumed to cause the formation of depressions and cracks in the cap. The cap is assumed to remain above-grade when subsidence is complete.

The Area 5 RWMS conceptual model of radionuclide release assumes that contaminants are released from waste to the overlying soil cover by gaseous diffusion, upward liquid advection, plant uptake, and animal burrowing. The Area 5 RWMS includes two types of deep disposal units that are below the depth of biointrusion, a 15-m- (48-ft)-deep trench (P06U) and 36-m$(118-\mathrm{ft})$-deep GCD boreholes. The only credible upward release processes for these units are gaseous diffusion, gaseous advection, and liquid advection. Screening analyses indicate that the mean distance the most mobile dissolved solute could be advected upward in 1,000 years under the current dry conditions is $0.01 \mathrm{~m}(0.03 \mathrm{ft})$. This distance is not sufficient to transport radionuclides from P06U and GCD boreholes to a depth where biointrusion is likely. Therefore, the nonvolatile inventory of P06U and the GCD boreholes was excluded from the analysis. The volatile radionuclide inventory in the deep disposal units is limited to ${ }^{3} \mathrm{H}$ in GCD boreholes. The GCD ${ }^{3} \mathrm{H}$ inventory was combined with the inventory in the shallow pits and trenches to give a conservative estimate of the potential ${ }^{3} \mathrm{H}$ releases.

Based on DOE CA guidance (DOE, 1996a), it is assumed that the CAUs will not be remediated, because definite plans for their closure do not exist at this time. The underground nuclear tests included in the Frenchman Flat UGTA were all conducted near, or in a single case in, the uppermost aquifer. Contaminants are assumed to be leached from the test debris and transported away from the detonation site in the groundwater. Radionuclide concentrations at the Frenchman Flat playa soil site and GMX soil site are assumed to change little over the 1,000-year compliance period. The long-term risks of both sites are dominated by isotopes of plutonium and ${ }^{241} \mathrm{Am}$. The inventory of these long-lived radionuclides will change little over the next 1,000 years. Contamination at the soil CAUs is assumed to be resuspended into the atmosphere and dispersed throughout Frenchman Flat.

The TEDE to a future resident of Frenchman Flat was calculated for a member of a small rural community. The residents are assumed to work at an off-site location. While at home, residents are exposed to residual contamination by external irradiation from nonvolatile radionuclides in soil and gaseous radionuclides in air; immersion in gaseous radionuclides in air; inhalation of 
soil particulates in air; inadvertent ingestion of soil; and ingestion of vegetables, beef, poultry, milk, and eggs. Agriculture is assumed to be noncommercial and limited by the infertile soil and arid conditions at the site.

\section{Results}

The highest TEDEs are expected for future residents of Frenchman Flat living in one of the contaminated soil sites at the Area 5 RWMS, the Frenchman Flat playa soil site, or the GMX soil site. The dose at the Area 5 RWMS is expected to increase over the compliance period, while the dose at the Frenchman Flat playa soil site and GMX soil site is expected to decrease slightly. Overall, there is relatively little change in the dose over 250 to 1,000 years after closure. The highest TEDE for an individual source, 6 mrem in a year, is expected for a resident living in the GMX soil site at 250 years after closure. An annual TEDE of 1 mrem was estimated for the Area 5 RWMS at 1,000 years. The highest TEDE estimated for a resident living outside a contaminated site was 0.2 mrem in a year. This dose was estimated for a resident living near the GMX soil site.

The dose for the interacting sources can be estimated by considering the spatial distribution of the dose for each individual source. The combined TEDE at each contaminated soil site is the sum of the dose from the underlying contaminated soil and the dose received through the atmospheric pathway from the other soil sites. The highest mean TEDE was at the GMX soil site and was less than 7 mrem in a year. The TEDE from interacting sources at the Area 5 RWMS is estimated to be less than 2 mrem in a year. The combined TEDE for the sources considered was less than the 100 mrem dose limit and 30 mrem dose constraint throughout the compliance period.

The contaminated soil sites interact through the atmospheric pathway only. The TEDE at each contaminated soil site is dominated by the underlying soil contamination. There is relatively little interaction between the three sites considered. Therefore, the Area 5 RWMS can be operated without consideration of the other contaminated soil sites in Frenchman Flat. And conversely, the Frenchman Flat playa soil site and the GMX soil site can be remediated and closed without consideration of the Area 5 RWMS.

The most important source of uncertainty in the CA results is the location of future land-use boundaries, particularly the location of the Frenchman Flat UGTA restricted area. The groundwater contaminant boundary for the Frenchman Flat UGTA has not been determined because of the large uncertainty in the source inventory, source term release rates, site hydrostratigraphy, groundwater flow paths and velocities, and aquifer transport parameters. The TEDE within the restricted areas has not been estimated and may exceed the CA dose limit or dose constraint. The design and performance of the Area 5 RWMS final closure cap is a source of uncertainty. Subsidence of the closure cap below grade and failure of the flood control berms combined with extreme flooding events has the potential to initiate a groundwater pathway at the Area 5 RWMS. Although higher doses would occur under these circumstances, this is an extremely low-probability event that can be mitigated by proper design and installation of a thick alluvium cap. The final state of the GMX soil site after remediation and closure is a source of uncertainty. The TEDE for this site is a conservative estimate that assumes no remediation. Lower doses are 
expected because the Soils Program is expected to remediate and close this site. Land use is a source of uncertainty. The residential land use assumed is conservative for Frenchman Flat. More probable land uses should reduce the possible doses. Model parameter uncertainty is a relatively small source of uncertainty in the results. Combining the 95 th percentile results for the sources considered in the CA, increases the maximum TEDE to less than $11 \mathrm{mrem}$ in a year.

\section{Conclusions}

The purpose of this initial CA is to determine if continuing operation of the Area 5 RWMS poses an acceptable or unacceptable risk to the public considering the total waste inventory and all other interacting sources of radioactive material in the vicinity. The TEDE estimated for the Area 5 RWMS and the three contaminated soil sites is less than $30 \mathrm{mrem}$ in a year throughout the 1,000- year compliance period. The Area 5 RWMS and the contaminated soil sites appear to have relatively little potential to interact and can be managed independently. The Area 5 RWMS is not expected to have any impact on groundwater under current climatic conditions.

This initial CA has not estimated the TEDE from the Frenchman Flat UGTA, because of the large uncertainty in the source term and transport parameters. There still exists a potential for interaction between the Frenchman Flat UGTA and any of the contaminated soil sites. As there are not likely to be cost-effective remediation options for the UGTA CAUs, the current objective of the UGTA Program is to control groundwater use and subsurface intrusion or restrict access to areas where groundwater has been impacted by the Frenchman Flat UGTA. The boundary of these restricted areas will correspond with a 4 mrem in a year dose at the 50 percent confidence level over a period of 1,000 years. Therefore, the TEDE for soil sites outside the restricted area may increase by up to 4 mrem in a year. Because the TEDE estimated for the Area 5 RWMS and each soil site is less than 26 mrem in a year, it is likely that soil sites outside the UGTA restricted area will comply with the CA dose limit and dose constraint. If a soil site is determined to be within the UGTA restricted area, reasonable assurance cannot be provided at this time that the dose is less than the CA limit. However, if land-use controls are assumed to be effective at eliminating the groundwater dose, the CA results show that the TEDE will remain below the 30mrem dose constraint. These observations support the conclusion that continuing operation of the Area 5 RWMS does not pose an unacceptable risk and will not have a significant impact on the remediation and closure of UGTAs and contaminated soil sites within Frenchman Flat.

The primary source of uncertainty in the CA result is the dose contribution from the Frenchman Flat UGTA. The only effective options that will reduce uncertainty in the CA results are those that address the Frenchman Flat UGTA. The management option for the Frenchman Flat UGTA has been selected by the DOE UGTA Program through the FFACO process. The current plan is to obtain additional site characterization for Frenchman Flat and to develop a new CAU model. The model will be used to establish a restricted area based on a 4 mrem in a year dose from use of groundwater. The results of the investigation will be documented in a Corrective Action Decision Document (CADD) expected in 2003. The CA will be revised and updated when the CADD is published. 


\subsection{INTRODUCTION}

This report describes the methods and results of a Composite Analysis (CA) prepared for the Area 5 Radioactive Waste Management Site (RWMS). The Area 5 RWMS, located in northern Frenchman Flat on the Nevada Test Site (NTS), is a low-level radioactive waste (LLW) disposal site operated by the U.S. Department of Energy's National Nuclear Security Administration Nevada Operations Office (NNSA/NV) (formerly DOE/NV).

In the future, members of the public residing near DOE LLW disposal sites may be exposed to radioactive materials released from all sources remaining at the site. In 1995, the DOE requested that all LLW disposal site operators prepare an integrated radiological assessment, known as a CA, that would assess the combined radiological hazards posed by LLW disposal sites and all radioactive sources interacting with LLW disposal sites (DOE, 1995a,b). DOE committed to preparing CAs in response to Defense Nuclear Facilities Safety Board (DNFSB) Recommendation 94-2 (DOE, 1995b). Completion and approval of a CA is one of several requirements that must be met to receive a Disposal Authorization Statement (DAS) from the DOE for operation of a LLW disposal site. Other requirements are: completion and approval of a Performance Assessment (PA), and submission of a PA/CA maintenance plan, preliminary closure plan, and a preliminary monitoring plan.

This CA is a complementary analysis to the Area 5 RWMS PA (Shott et al., 1997a). Performance assessment is a systematic analysis of the potential risks posed by waste management systems to the public and environment, and a comparison of those risks to established performance objectives (DOE, 1988). A PA, however, is limited to an analysis of the risks posed by LLW disposed after September 26, 1988, the implementation date of DOE Order 5820.2A, "Radioactive Waste Management" (DOE, 1988). The Area 5 RWMS PA was found to be acceptable with conditions in August 1996, and was revised to incorporate review comments.

This report is prepared using the Guidance for a Composite Analysis of the Impact of Interacting Source Terms of the Radiological Protection of the Public from Department of Energy LowLevel Waste Disposal Facilities (DOE, 1996b). The report is organized into nine chapters and three appendices, as briefly described:

- Chapter 1, Introduction, presents the CA performance objectives and summarizes important CA assumptions.

- Chapter 2, Overview of the NTS and the Area 5 RWMS, provides a brief summary of the environmental setting, and describes the past, present, and future operations at the Area 5 RWMS. A more comprehensive account of the regional and site-specific geology, hydrology, seismicity, and volcanism can be found in the Area 5 RWMS PA (Shott et al., 1997a).

- Chapter 3, Data Quality Objectives (DQOs), describes how the DQO process was used to prepare the CA. The environmental management decision to be supported by the CA is identified. The existing site knowledge, data sources, and data needs are described. 
Existing programs and field investigations that will provide data for future iterations of the CA are identified. Important assumptions made in Chapter 1 are supported.

- Chapter 4, Radionuclide Inventories, summarizes the radionuclide inventory estimates and the results of preliminary screening analyses. A more complete technical discussion of the inventory estimates is contained in Appendix 1.

- Chapter 5, Performance Analysis, describes and justifies the conceptual models of the radionuclide source terms, the release of radionuclides to the accessible environment, and the exposure of future residents to released radioactive materials. A complete discussion of the mathematical implementation of the conceptual models is contained in Appendices 2 and 3.

- Chapter 6, Results of Analyses, describes the total effective dose equivalents (TEDEs) estimated for a future receptor residing in Frenchman Flat. Uncertainty and sensitivity are discussed.

- Chapter 7, Interpretation of Results, integrates the results for all radionuclide source areas and compares the integrated results with the dose limit and dose constraint. The uncertainty and sensitivity of the results are described and discussed. The management option chosen to ensure compliance with the CA requirements is discussed.

- Chapter 8, Preparers, lists the preparers and describes their experience and qualifications.

- Chapter 9, References, lists references cited in the report.

\subsection{Primary Dose Limit and Dose Constraint}

The results of the CA are interpreted by comparing the best estimate of the TEDE for an average future resident at the compliance boundary with the primary dose limit of 100 mrem in a year and the dose constraint of $30 \mathrm{mrem}$ in a year. A TEDE greater than $100 \mathrm{mrem}$ in a year indicates that there is a potential for the DOE primary dose limit to be exceeded in the future if no action is taken. This indicates that LLW disposal sites and sources of residual radioactive material may have to be remediated or controlled in the future. If the TEDE falls between 30 and $100 \mathrm{mrem}$ in a year, then an options analysis is required. An options analysis is a cost-benefit optimization process performed to select the most cost-effective management option. Options that may be considered include taking no action, refining the CA to reduce uncertainty, improving the LLW facility design, limiting the future disposal of LLW, altering waste acceptance criteria, and remediation of radioactive contamination. If the estimated TEDE is less than 30 mrem in a year, then a determination that doses are as low as reasonably achievable (ALARA) may still be performed if warranted. 


\subsection{Important Assumptions}

Important CA assumptions are summarized in the following sections that address institutional control, the compliance period, the land-use and compliance boundary, future site conditions, and the performance of the engineered closure cap. The justifications for these assumptions are discussed more completely in Chapter 3, Data Quality Objectives.

\subsubsection{Institutional Control}

Institutional controls are active and passive measures taken to limit the radiation exposure to the public. Active institutional controls include physical security which restricts public access to the site, and other measures including administrative programs that ensure compliance with DOE Orders and external agreements. These programs ensure that radioactive materials and radiologically contaminated areas are properly identified, posted, and controlled. The NNSA/NV currently has programs to ensure compliance with DOE Order 5400.5 that limits annual exposure of the public to $100 \mathrm{mrem}$ in a year (DOE, 1990). U.S. Department of Energy Order 5400.5 also contains conditions and requirements for unrestricted release of land. The NNSA/NV has entered into the Federal Facility Agreement and Consent Order (FFACO) with the U.S. Department of Defense (DoD) and the state of Nevada (DOE, 1996e). This agreement specifies a process for the identification, remediation, and closure of corrective action sites (CASs) on the NTS. Passive institutional controls include records and knowledge of the site, signs and markers, and physical barriers.

Active institutional controls are assumed to be effective at controlling the radiological exposures of the public. There are currently no plans to remove institutional controls placed on lands within the current NTS boundary. Because of past activities, including both atmospheric and underground nuclear weapon tests, some land within the NTS boundary currently cannot be released for unrestricted use without remediation. In some cases, it may not be cost-effective to remediate residual contamination from underground nuclear testing and long term land-use restrictions may be required. The NTS Environmental Impact Statement (EIS) (DOE, 1996c) and Resource Management Plan (DOE, 1998a) state that one of the primary mission goals of the NTS is to "preserve the capability to resume underground nuclear testing ... and accomplish stockpile stewardship and national security missions" (DOE, 1998a). Therefore, the current expectation is that public access to the NTS will be restricted as long as the NTS is an operational Defense Program facility (DOE, 1999a, 1996c).

A panel of independent SMEs has evaluated the effectiveness and probable duration of long-term institutional controls in Frenchman Flat (Black et al., 1998). The SME consensus opinion supports the conclusion that there is a 50 percent probability that active institutional controls will continue for 250 years in Frenchman Flat. Therefore, the CA assumes that some portion of the land currently within the NTS boundary will be available for public use in the future. The public may gain access to the NTS by deliberate release of clean or remediated land or by an unintentional loss of control of the site. The CA assumes that active institutional control of Frenchman Flat will end 250 years after closure of the Area 5 RWMS. 


\subsubsection{Compliance Period}

The compliance period for the CA, set by guidance as 1,000 years, is assumed to begin at the closure date assumed in the Area 5 RWMS PA (2028). Members of the public are assumed to have access to Frenchman Flat at 250 years after closure of the RWMS. Exposures during the 250-year period of active institutional control are expected to be negligible based on current environmental monitoring data and the effectiveness of active institutional controls.

\subsubsection{Land Use and Compliance Boundary}

The future land use of the NTS will be determined by land-use constraints and opportunities. Land-use constraints are natural or man-made features that preclude or limit future activities (DOE, 1996c). Land-use opportunities are the best uses of the land that can be made within the limitations of the existing constraints (DOE, 1996c). Historical uses of the NTS, including nuclear weapon testing, nuclear rocket testing, and nuclear waste disposal, have placed constraints on the future uses of NTS lands (DOE, 1996c). Radioactive contamination and land instability caused by these activities will continue to constrain the use of some lands on the NTS indefinitely (DOE, 1999a, 1996c). The NTS EIS and Resource Management Plan identify the primary mission of the NTS to be preservation of underground testing capabilities and accomplishment of the stockpile stewardship and national security missions (DOE 1998a, 1996c). Portions of Frenchman Flat currently have three land-use designations: (1) defense industrial; (2) research, test, and experiment; and (3) radioactive waste management (DOE, 1998a).

To remove the land-use constraints resulting from radiological contamination, DOE would have to remediate and/or close historically contaminated areas. The release criteria would have to be agreed upon in the FFACO process and meet the requirements contained in DOE Order 5400.5 (DOE, 1990). Lands not meeting these release criteria will remain under DOE control indefinitely.

The CA recognizes DOE's requirement to control public access to contaminated sites and that there is a potential for unplanned loss of control in the distant future. The CA makes the assumption that the public has access to Frenchman Flat at 250 years after closure, based on the opinions of a panel of SMEs. The CA results provide a conservative estimate of the potential doses to future residents anywhere within Frenchman Flat, assuming that no remediation occurs and that loss of institutional control occurs at 250 years. The results are expected to be conservative because the DOE Environmental Restoration program will remediate and/or close historically contaminated sites under the FFACO. The CA results provide a preliminary indication of areas within Frenchman Flat that may require additional evaluation, remediation, or long-term land-use controls, and indicates the impact of continuing operation of the Area 5 RWMS on these decisions.

\subsubsection{Future Site Conditions}

The CA assumes that current site environmental conditions will persist for 1,000 years after closure of the Area 5 RWMS. Precipitation falling on the Area 5 RWMS is assumed to be 
returned to the atmosphere through evapotranspiration before reaching the uppermost aquifer based on site characterization data described in the Area 5 RWMS PA. Cleanup and closure of corrective action units (CAUs) is assumed not to occur because remediation plans have not been finalized between DOE and the state of Nevada. The public is assumed to have free access to the Frenchman Flat basin 250 years after closure of the Area 5 RWMS. A small community of commuters is assumed to reside in the basin based on the results of the site-specific community scenarios developed by the SMEs through elicitation (Black et al., 1998).

\subsubsection{Performance of the Engineered Closure Cap}

The closure concept of the Area 5 RWMS has evolved since preparation of the Area 5 RWMS PA (Shott et al., 1995). DOE Headquarters' review of this PA had identified subsidence as a major concern because it was unknown if subsidence would lead to creation of a groundwater pathway with adverse impacts on the groundwater. While the next iteration of the PA (Shott et al., 1997a) was in preparation, DOE/NV convened a working group to consider the consequences of subsidence at both the Area 3 RWMS and the Area 5 RWMS, and to make recommendations concerning final closure. The group's findings and recommendations appear in the Consequences of Subsidence Report (DOE, 1998b). The report finds that the waste already in place in the disposal units contains significant amounts of void space resulting from incomplete filling of waste containers, limited internal compaction of contents, and void space between containers. These void spaces will produce significant subsidence as the waste containers deteriorate and collapse over time. Rates of decay for different containers will vary. However, significant subsidence (i.e., due to decay of steel containers) will occur well beyond the assumed institutional control period of 250 years. The study also showed that cover designs including soil-cement and soil-bentonite layers would not function as intended considering the estimated subsidence rates for the disposal units. The report concluded that an alternative closure cover design consisting of a thick layer of native alluvium should be developed for application at the RWMSs. The cover design should rely upon thickness and evapotranspiration to provide containment. This design would provide long-term stability and performance, and would be inexpensive to build because of availability of materials at the NTS.

To address the DOE Headquarters concern with a specific consequence of subsidence - that of the potential for groundwater contamination - a bounding analysis was performed in the Area 5 RWMS PA (Shott et al., 1997a) by assuming the simultaneous occurrence of low-probability events. A closure cover failure scenario was considered, where the entire Area 5 RWMS closure cover instantaneously subsided $2 \mathrm{~m}(6.6 \mathrm{ft})$ below the surrounding grade, creating a large depression. The depression was completely filled with water from a 200 -year flood in three successive years (it was assumed that no berms protect the site against run-on from the tributary drainages). The joint occurrence of these two events (instantaneous 2-m [6.6-ft] uniform subsidence and three 200-year floods in succession) is extremely small. The vadose zone modeling of this bounding scenario showed that infiltrated water would reach the uppermost aquifer in approximately 140 years. The retarded transport of sorbing contaminants through the unsaturated and saturated zones to a water supply well at the site boundary was estimated to take more than 
1,000 years. Water at the water supply well was found to comply with Title 40 Code of Federal Regulations (CFR) 141, "National Primary Drinking Water Regulations" (U.S. Environmental Protection Agency [EPA], 1998) throughout the 10,000-year compliance period.

Therefore, it is assumed in this CA that the Area 5 RWMS closure cap, which is the one recommended by the Consequences of Subsidence Report (DOE, 1998b), will remain above grade when subsidence is complete and ponding of run-on on the site will not occur. The CA also assumes that there is a 100-year period of maintenance and monitoring during which subsidence is repaired and deep-rooted vegetation is removed from the cap. 


\subsection{OVERVIEW OF THE AREA 5 RWMS AND ENVIRONS}

The NTS is an approximately 3,560-square-kilometer $\left(\mathrm{km}^{2}\right)\left(1,375\right.$-square-mile [mi $\left.\left.{ }^{2}\right]\right)$ DOE facility in southern Nye County, Nevada, approximately $105 \mathrm{~km}(65 \mathrm{mi})$ northwest of Las Vegas (Figure 2.1). The NTS was used as the continental nuclear weapons testing site from 1951 to 1992. The Area 5 RWMS is located in northern Frenchman Flat (Figure 2.2). The closest permanent settlement to the Area 5 RWMS is Indian Springs, $42 \mathrm{~km} \mathrm{(26} \mathrm{mi)} \mathrm{to} \mathrm{the} \mathrm{southeast.}$

The following sections summarize environmental conditions at the Area 5 RWMS. A more complete description of site conditions can be found in the Area 5 RWMS PA.

\subsection{Environmental Conditions}

The Area 5 RWMS lies within a biogeographical region transitional between the Mojave Desert and the Great Basin Desert. The site is surrounded by desert shrub communities characterized by low, but variable, productivity and low-standing biomass. The climate is extremely arid. Frenchman Flat receives an average of only 12 centimeters $(\mathrm{cm})(4.7$ inches [in]) of precipitation per year. Annual potential evapotranspiration is estimated to be about $168 \mathrm{~cm}(66$ in) or about 14 times mean annual precipitation.

Frenchman Flat is an alluvium-filled intermontane basin typical of the Basin and Range Physiographic Province, bounded by the Halfpint range to the north, the Ranger Mountains and Buried Hills to the east-southeast, Mount Salyer to the west, and Mercury Ridge and Red Mountain to the south (Figure 2.3). The basin elevations range from 1,600 meters (m) $(5,250$ feet [ft] $)$ above mean sea level in the surrounding mountain ranges to $940 \mathrm{~m}(3,080 \mathrm{ft})$ at Frenchman Flat playa, a dry lake bed at the lowest point of the basin. The basin drains a $1,200-\mathrm{km}^{2}\left(460-\mathrm{mi}^{2}\right)$ watershed.

The uppermost stratigraphic unit beneath the Area 5 RWMS consists of 360 to $460 \mathrm{~m}(1,200$ to $1,500 \mathrm{ft}$ ) of alluvium derived predominantly from Tertiary volcanic rocks and Paleozoic sedimentary rocks exposed in the nearby mountain ranges to the north (Figure 2.4). Beneath the alluvium lies a layer of interbedded ash-fall and ash-flow tuff, estimated to be more than $550 \mathrm{~m}$ $(1,800 \mathrm{ft})$ thick. The ash-flow tuff is underlain by an undetermined thickness of Paleozoic carbonate rocks which extend down to the Precambrian basement rocks.

The uppermost aquifers under the Frenchman Flat basin are the Alluvial Aquifer and the Timber Mountain Tuff Aquifer. The water table below the RWMS lies about $240 \mathrm{~m}(790 \mathrm{ft})$ below the ground surface. The water table is nearly flat, indicating that there is no significant horizontal flow beneath the RWMS in the saturated zone. The Tuff Aquitard, which is estimated to be in excess of $1,370 \mathrm{~m}(4,495 \mathrm{ft})$ thick, lies below the alluvium. Because of its relatively large areal extent and thickness, it is a major barrier for groundwater to move from the uppermost aquifers into the Lower Carbonate Aquifer below. The Lower Carbonate Aquifer is the regional aquifer 


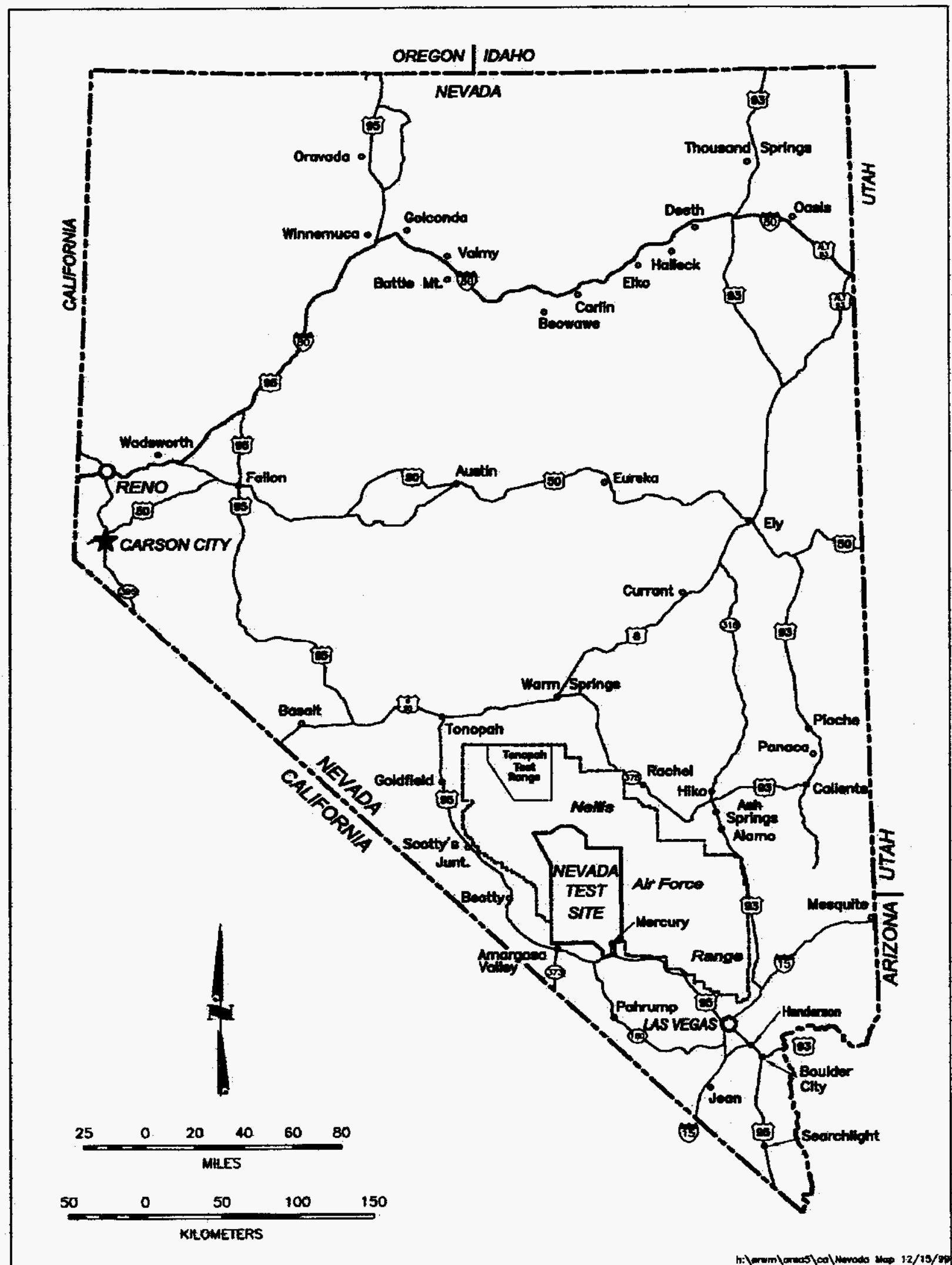

Figure 2.1 Location of the Nevada Test Site Within the State of Nevada. 


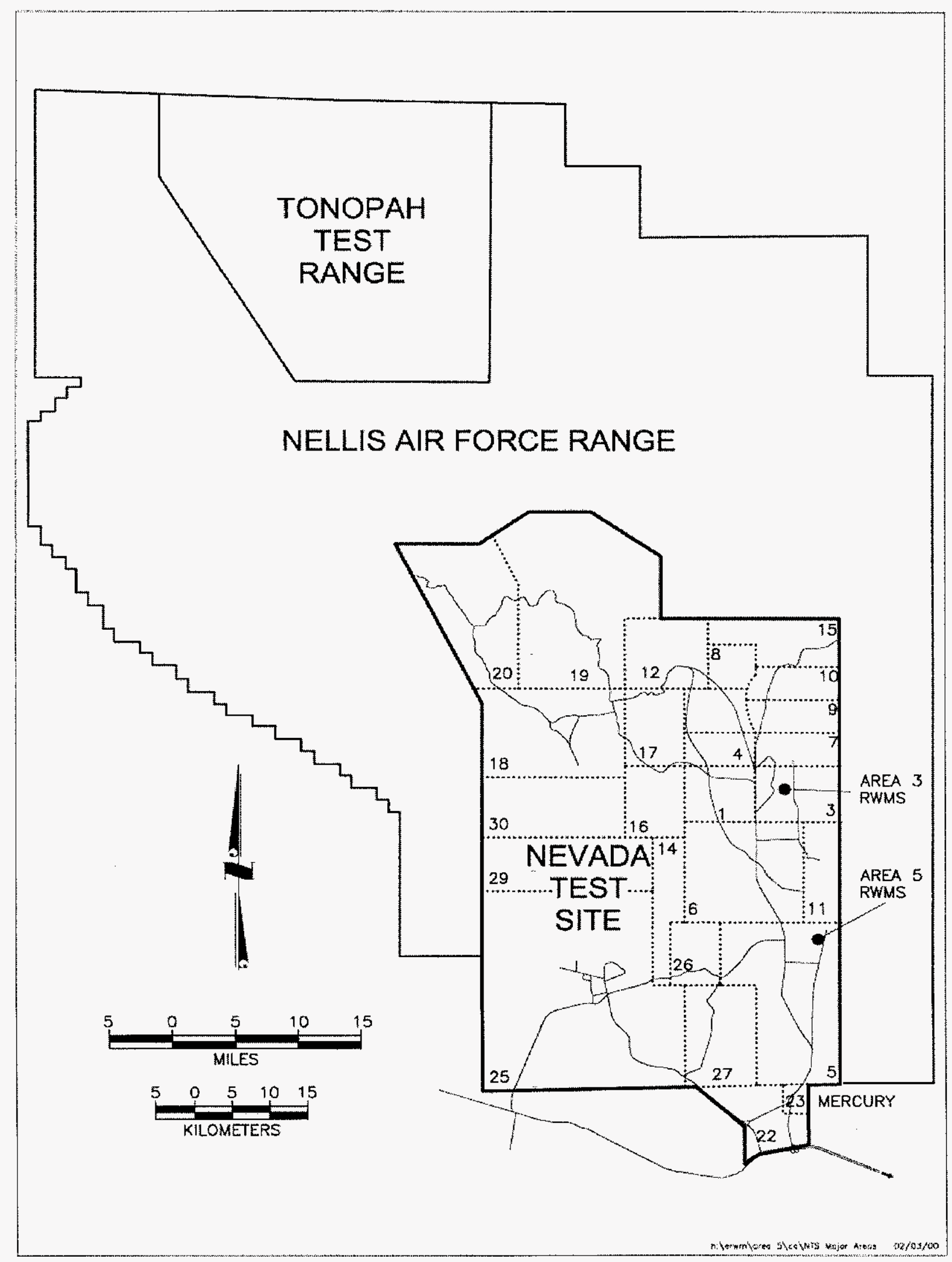

Figure 2.2 Location of the Area 5 Radioactive Waste Management Site on the Nevada Test Site. 


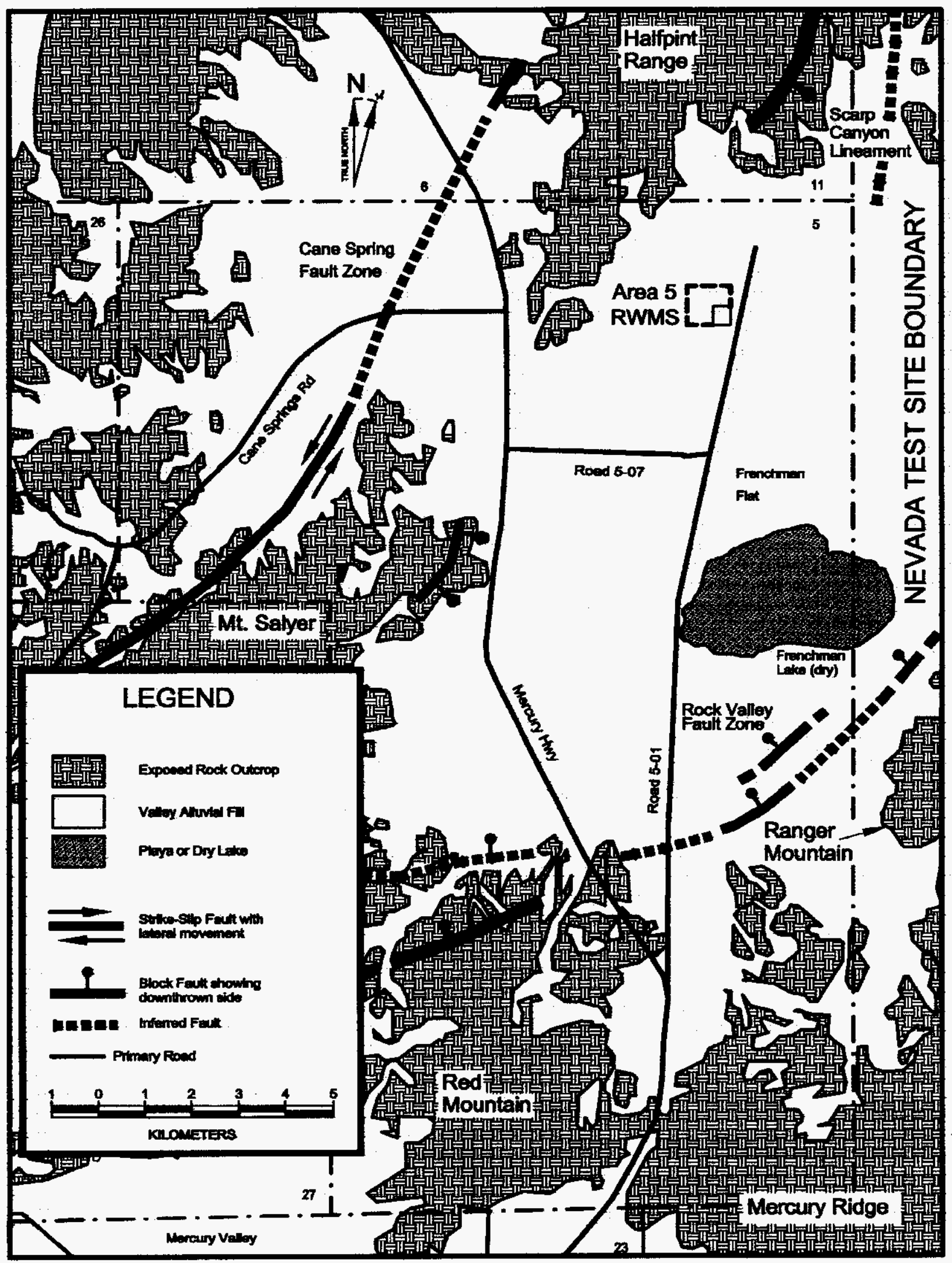

Figure 2.3 Surficial Geology of Frenchman Flat. 


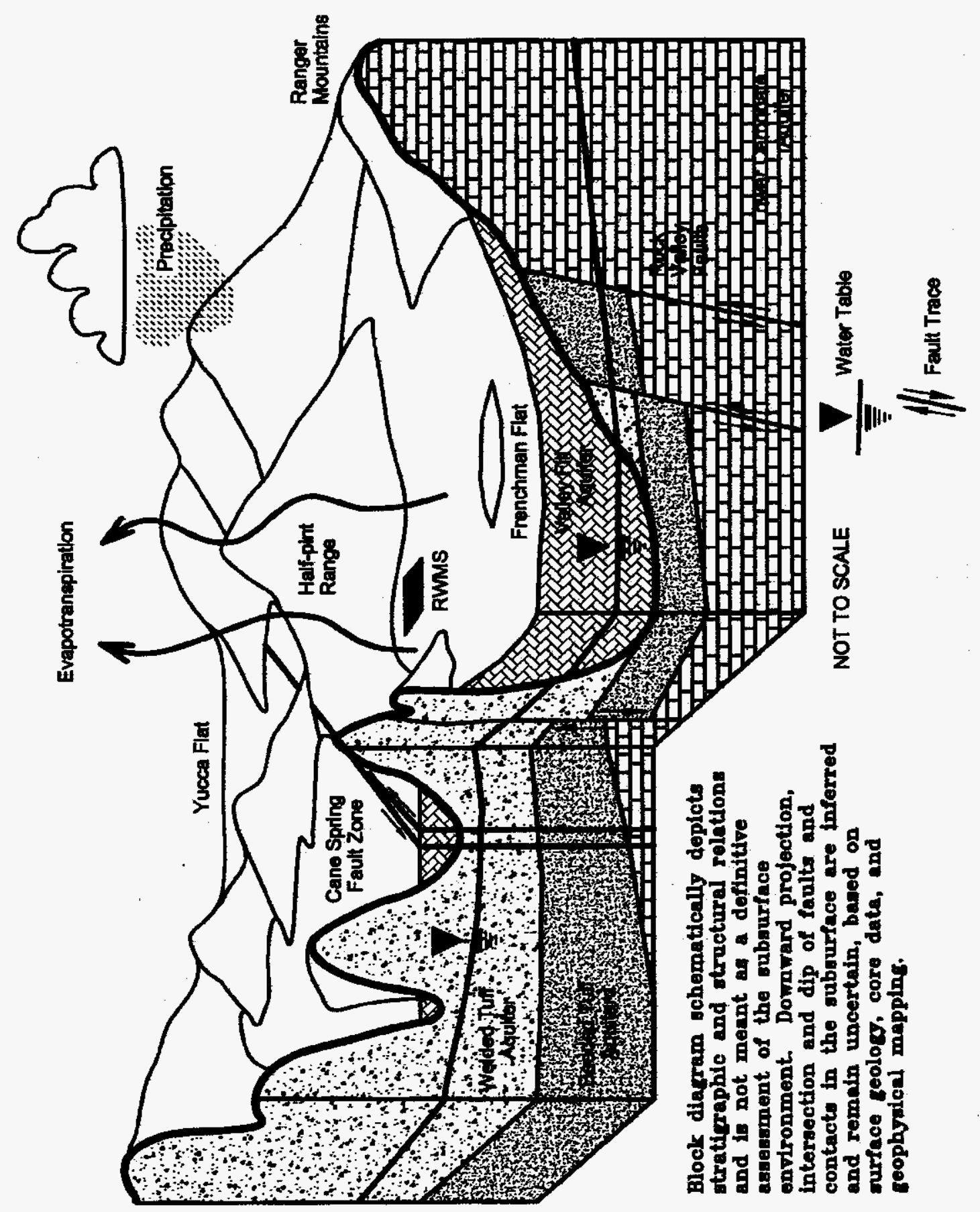

Figure 2.4 Hydrogeological Cross-Section of Frenchman Flat. 
underlying most of the eastern part of the NTS and is part of the Ash Meadows Groundwater Basin which discharges at Ash Meadows in the Amargosa Desert, $30 \mathrm{~km}$ (18.6 mi) south of the NTS (Figure 2.5).

Infiltration of precipitation through the alluvium to the uppermost aquifer is believed to be negligible under current climatic conditions. Chloride and stable isotope profiles indicate that infiltrating precipitation is removed in the near-surface alluvium by evapotranspiration. The accumulation of chloride beneath the rooting zone indicates that recharge below this depth is negligible. Chloride age dating indicates that infiltration below $10 \mathrm{~m}(33 \mathrm{ft})$ ceased 20,000 to 30,000 years ago.

The near-surface alluvium is very dry. The dry conditions are the result of evapotranspiration greatly exceeding precipitation. The evaporative demand is so high at the surface that the tendency for liquid flow in the top $35 \mathrm{~m}(115 \mathrm{ft})$ of alluvium is toward the surface, rather than downward to the aquifer. Below $35 \mathrm{~m}(115 \mathrm{ft})$ in the vadose zone, liquid will tend to move downward at extremely slow rates. In the unlikely event that leachate was to move below $35 \mathrm{~m}$ $(115 \mathrm{ft})$, the median travel time to the uppermost aquifer was estimated to be approximately 51,000 years (Shott et al., 1997a). Under current climatic and hydrologic conditions, there is a greater than 99 percent probability that travel time exceeds 10,000 years. Retardation due to sorption reactions would greatly increase this transport time for most radionuclides.

The near-surface alluvium is normally near its residual volumetric water content of approximately 8 percent. Radionuclide transport by upward advection or upward diffusion is believed to be insignificant at these low ambient water contents because of the extremely small unsaturated hydraulic conductivities expected.

The arid nature of the site also affects potential land use. The land surrounding the NTS remains mostly uninhabited because of limited water resources and government ownership. The population density of the surrounding counties is low $\left(0.5\right.$ persons $\left./ \mathrm{km}^{2}\right)$ compared with 28 persons/ $\mathrm{km}^{2}$ reported for the continental United States. Agriculture in Nevada is limited by the arid climate, infertile soils, and mountainous topography. Only 2.1 percent of the total land area in southern Nevada is used for agriculture. Production of livestock is the most common agricultural activity, accounting for approximately 90 percent of the land in farms. No economically significant mineral resources are known to exist within the vicinity of the Area 5 RWMS (Gustafson et al., 1993). Future development of Frenchman Flat appears unlikely assuming current land-use patterns continue.

\subsection{Radiological Environment}

U.S. Department of Energy operations creating significant radioactive source terms on the NTS include atmospheric and underground nuclear weapon testing, safety tests, nuclear rocket testing, and radioactive waste disposal. Associated with these operations are various industrial sites, such as equipment shops and decontamination facilities, where residual contamination may also be present. 


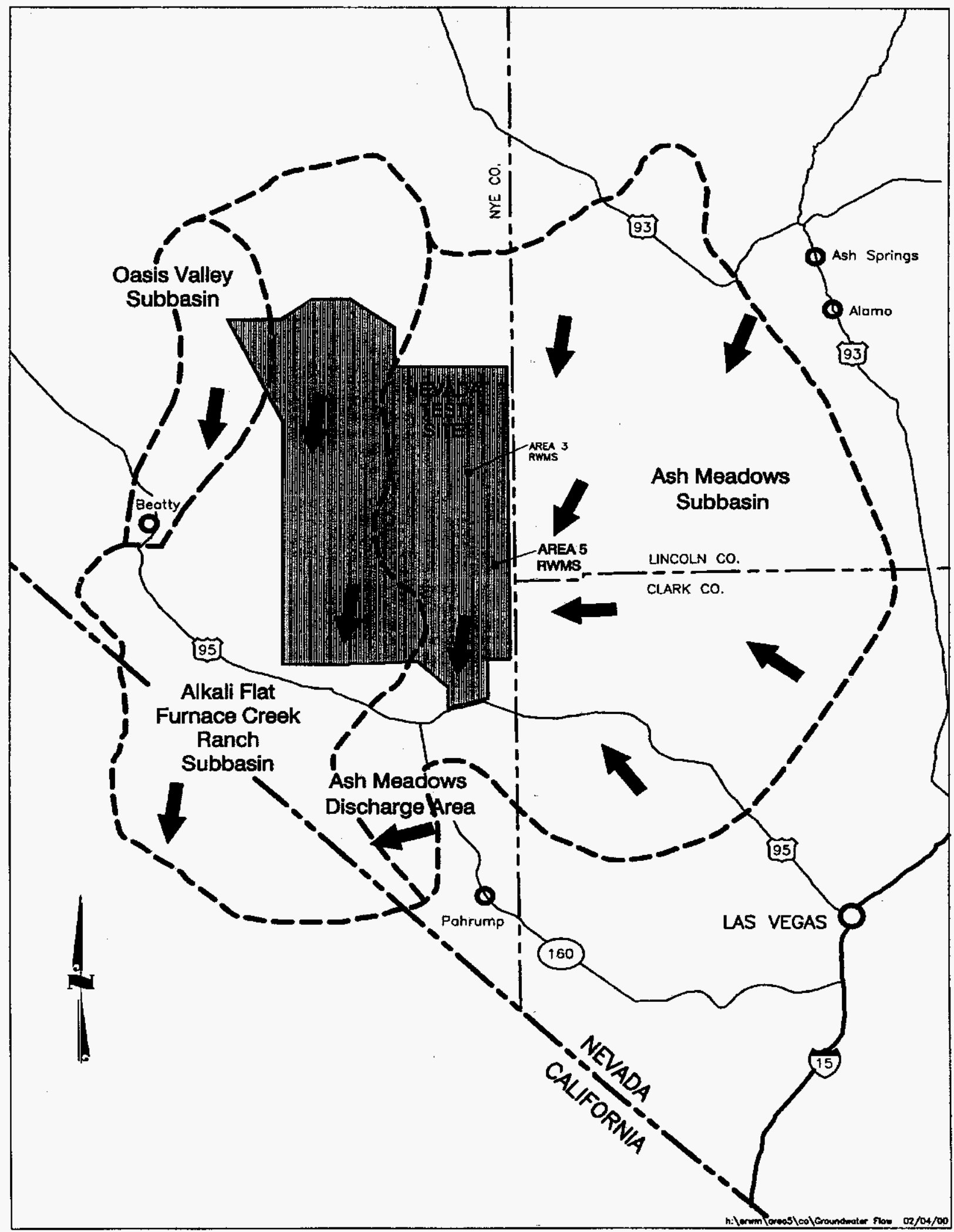

Figure 2.5

Principal Groundwater Subbasins and Groundwater Flow Directions Near the Nevada Test Site (from Laczniak et $a l$., 1996). 
Atmospheric nuclear testing is the detonation of a nuclear weapon at any elevation above the ground surface. Fallout from atmospheric testing can contaminate surface soils with activation products, fission products, and unfissioned weapon components. Tests conducted close to the ground surface may cause activation of soils and test equipment close to the ground zero (GZ). The GZ is the weapon's detonation position projected onto the ground surface. Atmospheric testing has occurred in Yucca Flat and Frenchman Flat (Figure 2.6). Between 1951 and 1962, 14 nuclear devices were detonated in the atmosphere over the Frenchman Flat playa, Area 5. Contamination from these tests remains in the Frenchman Flat playa soil site (CAU 106). During the same period, 80 atmospheric nuclear tests were conducted in Yucca Flat.

Underground nuclear testing is the detonation of a nuclear weapon at any depth below the ground surface. Underground nuclear tests release activation products, fission products, and unfissioned weapons components at the zero point and inject test debris into the surrounding soil and rock. The zero point is the position where the weapon is detonated. Underground nuclear tests are usually performed in boreholes or tunnels designed to contain the test debris. Early in the underground testing program, test containment failed occasionally and contamination was promptly released to the atmosphere. A few underground nuclear tests were conducted at shallow depths or in unstemmed boreholes where formation of a crater or prompt release of test debris to the atmosphere was expected. Some underground tests were conducted below or near the water table. Underground testing has occurred in Yucca Flat, Frenchman Flat, Pahute Mesa, Rainier Mesa, Shoshone Mountain, and Buckboard Mesa (Figure 2.7). In 1965, three underground nuclear tests were conducted northwest of Frenchman Flat playa, approximately 3.8 to $4.2 \mathrm{~km}$ (2.4 to $2.6 \mathrm{mi}$ ) south of the Area 5 RWMS (Figure 2.8). Seven more underground tests were conducted from 1966 to 1971 , approximately 1.5 to $3.0 \mathrm{~km}(0.9$ to $1.9 \mathrm{mi})$ northeast of the RWMS. These tests are within the Frenchman Flat Underground Testing Area (UGTA) (CAU 98). Nine of ten underground tests within the Frenchman Flat UGTA were conducted above the water table, but all tests were within $100 \mathrm{~m}(330 \mathrm{ft})$ of the water table (Table 2.1). From 1957 to 1992, 659 underground nuclear tests were conducted in Yucca Flat. The Yucca Flat underground nuclear tests closest to the Area 5 RWMS are $14 \mathrm{~km}(8.7 \mathrm{mi})$ to the northnorthwest.

Safety tests, equation-of-state experiments, and hydrodynamic experiments involve the nonnuclear destruction of a nuclear weapon or nuclear weapon components that may cause the dispersion of unfissioned weapon components into the atmosphere and surrounding soils. Some safety tests had low nuclear yields. On the NTS, these types of tests and experiments have occurred in Yucca Flat, Plutonium Valley, and Frenchman Flat. From 1954 to 1956, 24 equation-of-state experiments were conducted at the Gadgets, Mechanics, and Explosives (GMX) site, $2.1 \mathrm{~km}(1.3 \mathrm{mi})$ southeast of the Area 5 RWMS. Contamination from these tests remains in the GMX soil site (CAU 365) (Figure 2.8). Four safety tests were conducted during Project 56 in Plutonium Valley, a north-south trending valley draining into Yucca Flat. Plutonium Valley lies $13 \mathrm{~km}(8 \mathrm{mi})$ north of the RWMS and is separated from Frenchman Flat by French Peak and the Halfpint Range. Surface soil contamination from the Project 56 safety experiments remains in the Plutonium Valley soil site (CAU 366). 


\section{Atmospheric Tests at the NTS, 1951-1962}

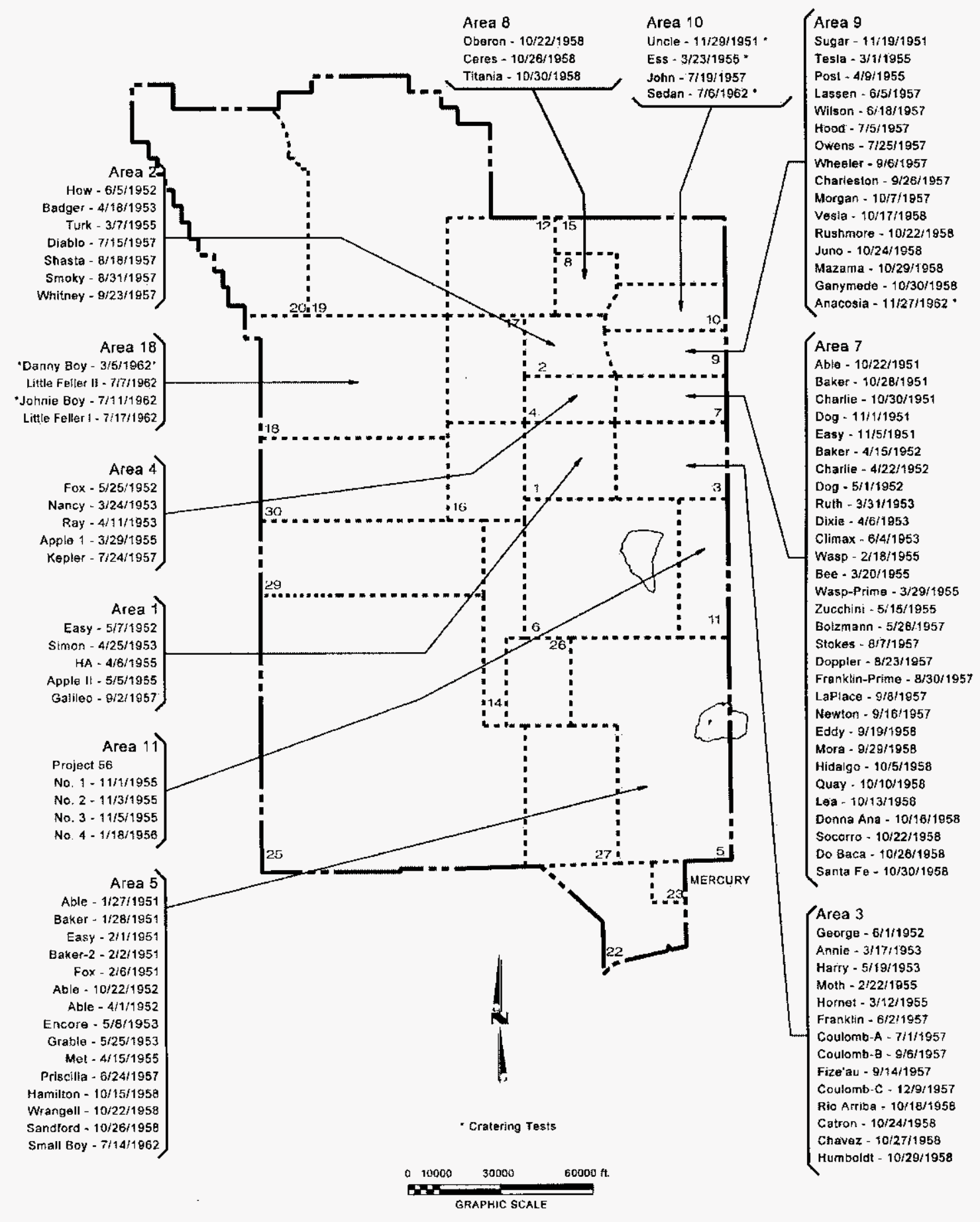

Figure 2.6 Weapons Tests Conducted at the Nevada Test Site (1951 to 1962). 


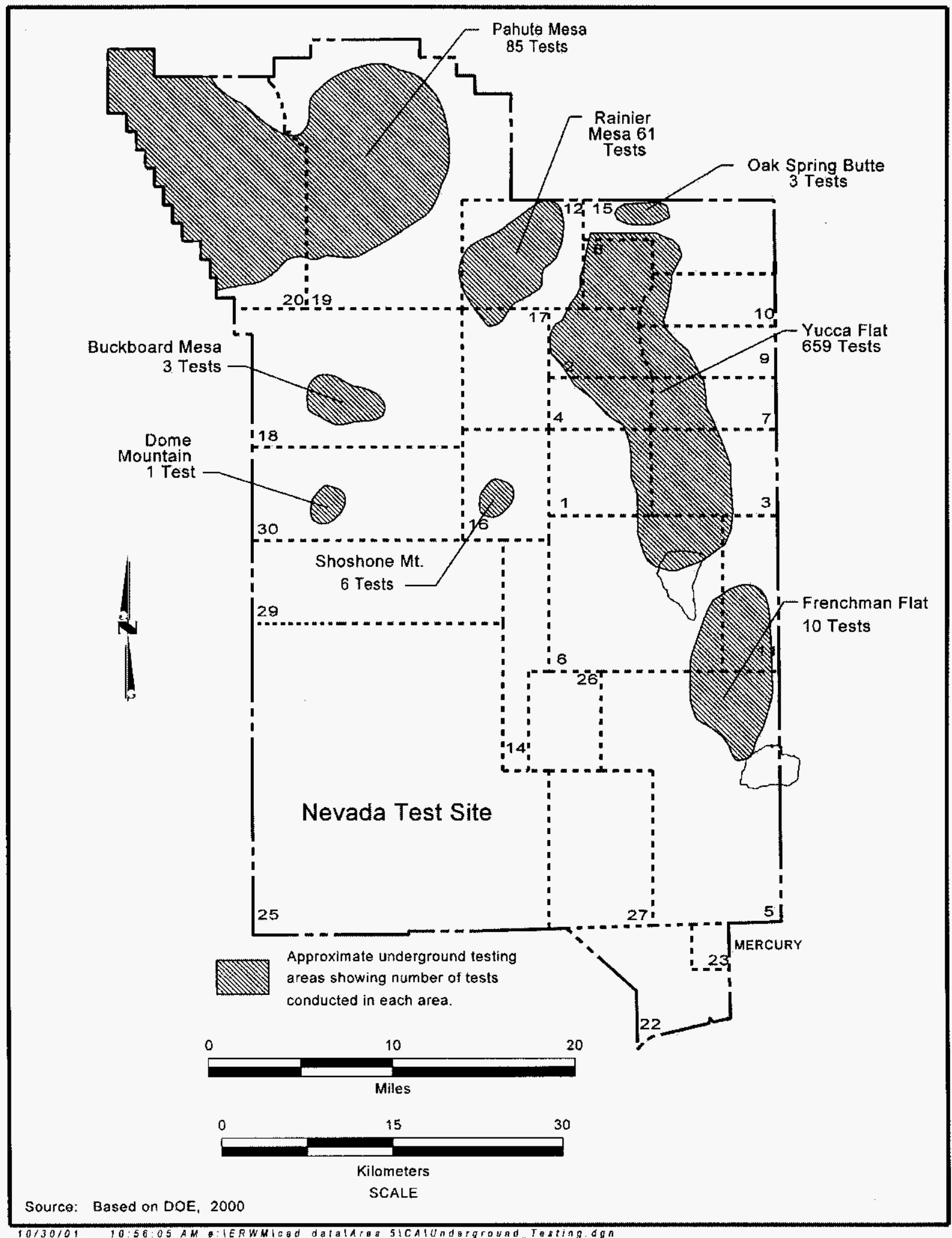

Figure 2.7 Location of Underground Testing Area Corrective Action Units on the Nevada Test Site. 


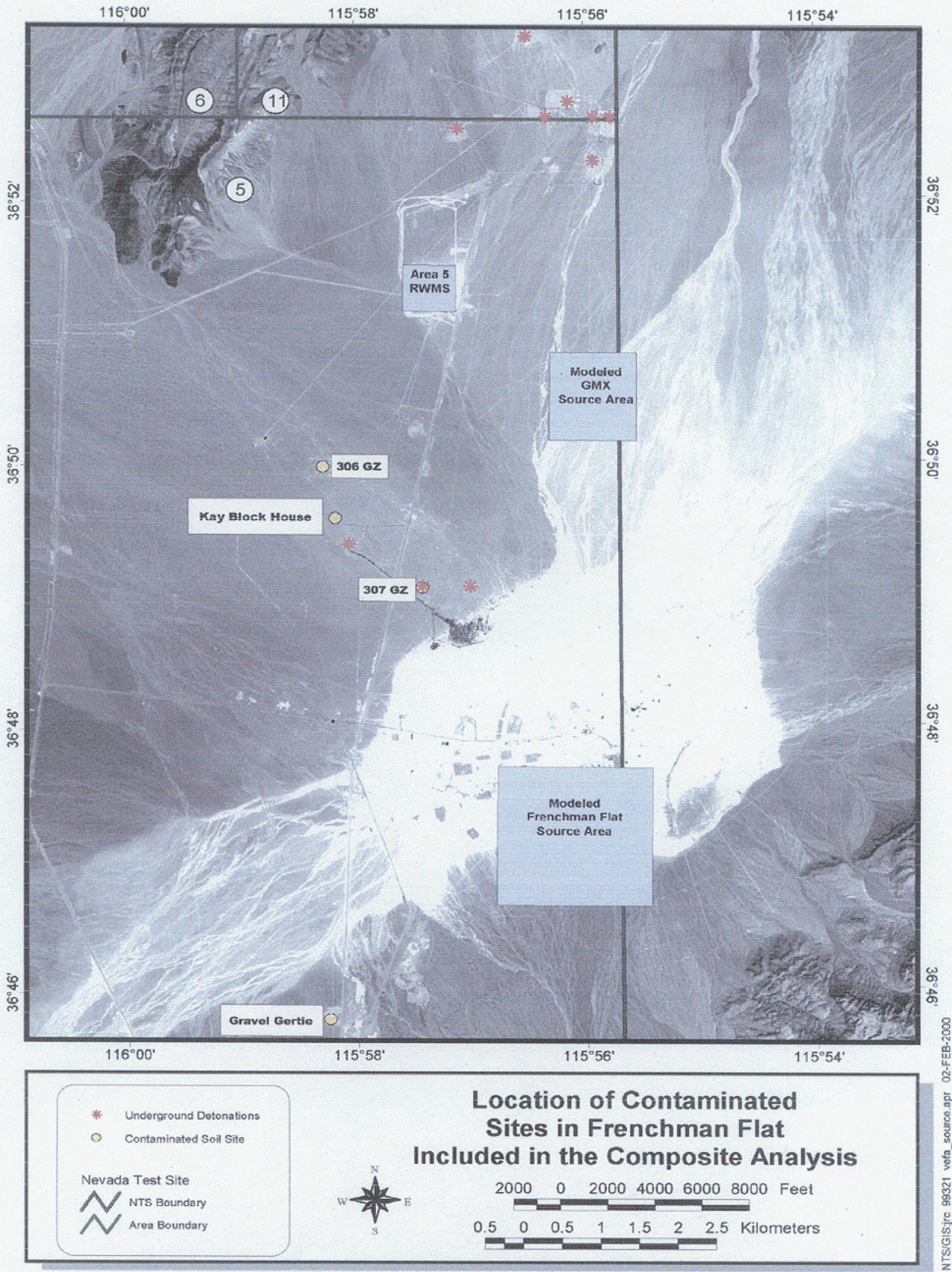

Figure 2.8 Location of Contaminated Sites in Frenchman Flat Included in the Composite Analysis. 
Table 2.1 Underground Nuclear Tests in the Frenchman Flat (from DOE, 2000)

\begin{tabular}{llllll}
\hline & & & $\begin{array}{l}\text { Estimated Depth } \\
\text { of Working }\end{array}$ & $\begin{array}{l}\text { Estimated } \\
\text { Depth of Water }\end{array}$ & Working Point \\
Borehole & Test Name & Date & Point (m) & $\begin{array}{l}\text { Table (m) } \\
\text { Rock Type }\end{array}$ \\
\hline U5a & WISHBONE & $2 / 18 / 1965$ & 175 & 206 & Alluvium \\
U5b & DILUTED WATERS & $6 / 16 / 1965$ & 193 & 208 & Alluvium \\
U5e & CAMBRIC & $5 / 14 / 1965$ & 295 & 218 & Alluvium \\
U5i & DERRINGER & $9 / 12 / 1966$ & 255 & 298 & Alluvium \\
U5k & MILK SHAKE & $3 / 25 / 1968$ & 265 & 282 & Alluvium \\
U11b & PIN STRIPE & $4 / 25 / 1966$ & 296 & 358 & Tuff \\
U11c & NEW POINT & $12 / 13 / 1966$ & 239 & 292 & Alluvium \\
U11e & DIANA MOON & $8 / 27 / 1968$ & 242 & 295 & Alluvium \\
U11f & MINUTE STEAK & $9 / 12 / 1969$ & 265 & 298 & Alluvium \\
U11g & DIAGONAL LINE & $11 / 24 / 1971$ & 264 & 301 & Alluvium \\
\hline
\end{tabular}

Rocket engines powered by fission reactors have been tested at the Nuclear Rocket Development Station in Jackass Flats. Nuclear rocket engine tests can cause the release of activation and fission products to the atmosphere. Radioactive wastes from nuclear rocket testing and decommissioning have been disposed in Jackass Flats.

Radioactive waste generated by NTS operations has been disposed in shallow trenches, boreholes, and injection wells at operational sites throughout the NTS. During the 1980s, some of these waste disposal sites were consolidated and the waste disposed at the Area 3 RWMS. Off-site-generated radioactive wastes have been disposed in shallow trenches and deep boreholes at the Area 5 RWMS in Frenchman Flat and in subsidence craters at the Area 3 RWMS in Yucca Flat.

Persons residing in unrestricted areas adjacent to the NTS or on NTS land released in the future will be exposed to internal and external sources of ionizing radiation from natural and man-made sources. The National Council on Radiation Protection (NCRP) has reported the average dose equivalent received by United States residents from background and man-made sources to be approximately $360 \mathrm{mrem} / \mathrm{yr}$ (NCRP, 1987). Average United States residents are estimated to receive approximately 82 percent of their annual effective dose equivalent from natural sources (NCRP, 1987). This corresponds to an effective dose equivalent of approximately $300 \mathrm{mrem} / \mathrm{yr}$, most of which is attributable to inhalation of naturally occurring ${ }^{222} \mathrm{Rn}$ progeny (NCRP, 1987).

Man-made sources of radiation are, on average, less important sources of exposure and include, in descending order of importance, medical procedures, consumer products, and industrial 
sources (NCRP, 1987). Industrial sources, which include DOE operations and nuclear weapons testing among many other sources, are estimated to account for approximately 0.8 percent of the average annual effective dose equivalent for United States residents, or approximately $2 \mathrm{mrem} / \mathrm{yr}$ (NCRP, 1987).

A future resident of the NTS living near the Area 5 RWMS may potentially be exposed to radionuclides at levels greater than average. The NTS on-site monitoring program collects air, soil, groundwater, vegetation, and biota samples at the Area 5 RWMS. Sampling and analysis of soils within the Area 5 RWMS and adjacent to the perimeter have shown that, except for ${ }^{3} \mathrm{H}$, man-made radionuclides are present at low concentrations, consistent with levels expected for global fallout throughout the southwest United States (Rothermich and Vollmer, 1986; Atwood and Hertzler, 1989). Groundwater monitoring results for the uppermost aquifer indicate that radioactive contamination is not present at the three Pilot Well locations surrounding the Area 5 RWMS (Bechtel Nevada [BN], 1997). Tritium is the only man-made radionuclide that has been detected in vegetation. The only man-made radionuclides detected at the Area 5 RWMS in 1996 were ${ }^{3} \mathrm{H}$ and ${ }^{239,240} \mathrm{Pu}$ in air (DOE, 1997a). The mean ${ }^{3} \mathrm{H}$ and ${ }^{239,240} \mathrm{Pu}$ concentrations (3.6e-12 $\mu \mathrm{Ci} / \mathrm{ml}$ and $5.3 \mathrm{e}-18 \mu \mathrm{Ci} / \mathrm{ml}$, respectively) represent a committed effective dose equivalent (CEDE) of approximately $7 \mathrm{e}-3$ mrem in a year to an occupational worker.

Off-site environmental monitoring data indicate that all NTS activities, including waste disposal at the Area 5 RWMS, currently are insignificant sources of radiation exposure to off-site residents (DOE, 1997a). The future risk posed by the UGTAs in Yucca Flat and Frenchman Flat is also estimated to be negligible for at least the next 200 years (DOE, 1997b).

\subsection{Area 5 Radioactive Waste Management Site Description}

The developed portion of the Area 5 RWMS, referred to as the Low-Level Waste Management Unit (LLWMU), includes 37.2 hectares (ha) (92 acres [ac]) in the southeast corner of the RWMS (Figure 2.9). All waste disposal to date has occurred within the LLWMU. The remaining land, 259 ha $(640 \mathrm{ac})$, remains undeveloped.

The LLWMU consists of 23 landfill cells (shallow pits and trenches), 13 GCD boreholes, and a TRU Waste Storage Pad (WSP) (Figure 2.10). Historically, landfill cells have been described by a four-character code. The first character, either $\mathrm{T}$ or $\mathrm{P}$, designates whether the cell is a trench (long, narrow excavation) or a pit (broad excavation). The third character is the number assigned to the unit. The final character describes the contents of the cell as unclassified (U) or classified (C). A single pit, P03U, has received mixed waste (MW). Transuranic waste was inadvertently disposed in T04C. All other shallow pits and trenches contain LLW. Greater Confinement Disposal boreholes have received LLW, TRU, MW, high-specific activity waste, and similar to greater-than-Class $\mathrm{C}$ wastes. 


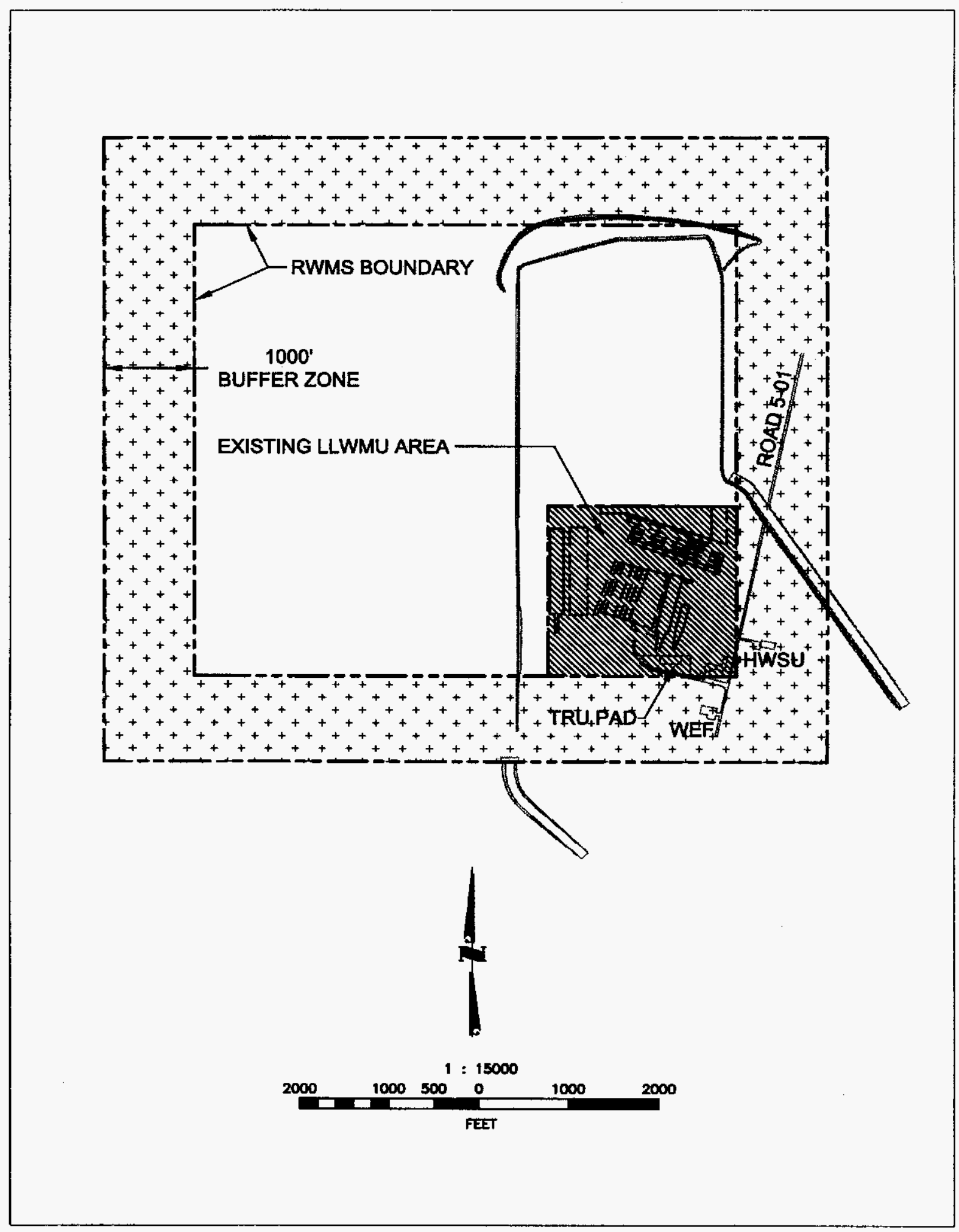

Figure 2.9 Layout of the Area 5 Radioactive Waste Management Site. 


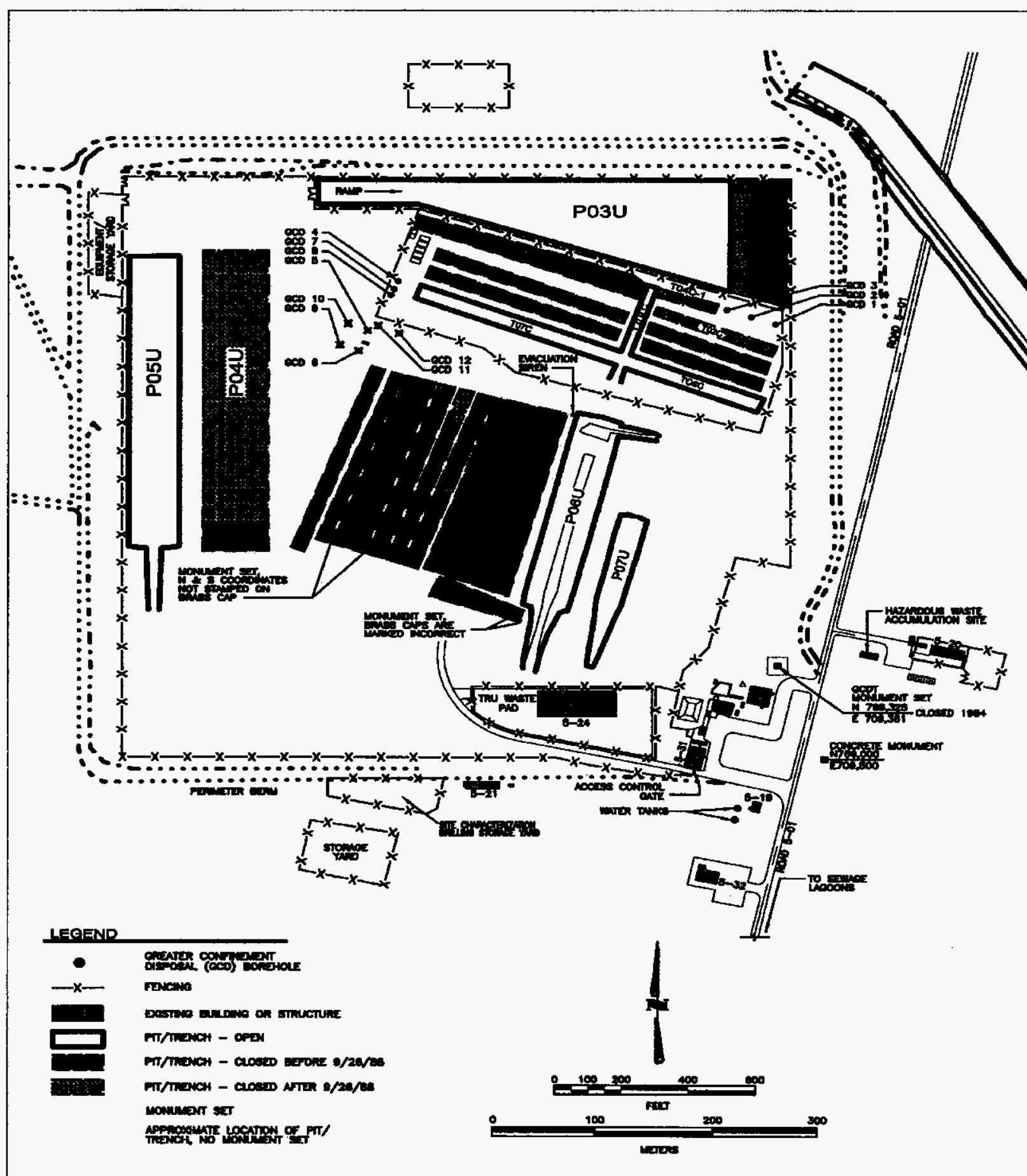

PITIRENCH LOCATIONPLAN

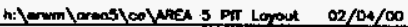

Figure 2.10 Locations of Disposal Units and Support Structures at the Area 5 Radioactive Waste Management Site. 
Associated with the LLWMU is the Hazardous Waste Storage Unit (HWSU), the Waste Examination Facility (WEF), and several administrative support structures (Figure 2.10). Two waste storage areas are within or adjacent to the LLWMU. These are the TRU WSP and the HWSU. The Mound Strategic Materials Storage Yard was closed in 1997 after the waste stored there was shipped off site.

Low-level radioactive waste disposal was initiated at the Area 5 RWMS in 1960. From 1960 to 1978, LLW generated predominantly by NTS operations were disposed at the site by shallow land burial. Eight trenches (T01U, T02U, T04U, T06U, T01C, T03C, T05C, T06C) were filled and closed during this period (Table 2.2). Waste generated during this period was a by-product of nuclear weapons testing and nuclear rocket testing and contain predominantly fission products, activation products, and lesser amounts of actinides.

Starting in 1978, the NTS began accepting LLW generated by off site DOE facilities. From 1978 until the implementation of DOE Order 5820.2A in 1988, two pits and one trench (P01U, P02U, T07U) were filled and closed. On September 26, 1988, a total of 11 shallow pits and trenches had been closed and four had received waste and remained open. Waste generated by off-site DOE generators commonly contains radionuclides used in, or produced as a by-product of, the production of nuclear weapons. Major radionuclides in this group include ${ }^{3} \mathrm{H}$ and isotopes of uranium and plutonium. In the late $1980 \mathrm{~s}$, DOE began to decommission its weapon production facilities. Since then, disposed waste has consisted predominantly of decontaminating and decommissioning debris from former weapons production sites.

Disposal in GCD boreholes began in 1983 and continued until 1989. Nine GCD boreholes were operationally active from 1983 to 1988 (Table 2.3 ).

Since the implementation of DOE Order 5820.2A on September 26, 1988, nine pits and trenches (P03U, P04U, P05U, P06U [Lower Cell], P07U, T02C, T03U, T04C, T09C) and two GCD boreholes have been active. The Area 5 RWMS PA addresses these units and units to be developed in the future. The CA address all units covered by the Area 5 RWMS PA, plus all waste disposed prior to September 26, 1988.

Currently, the Area 5 RWMS is open and receiving LLW from the NTS and off-site generators. The Area 5 RWMS does not accept nonradioactive hazardous waste or nonradioactive solid waste for disposal. All hazardous waste generated on site is transferred to an off-site commercial treatment, storage, and disposal facility. Nonradioactive solid wastes are disposed at solid waste landfills not associated with the Area 5 RWMS.

\subsubsection{Land Burial Operations in Pits and Trenches}

Low-level radioactive waste is currently landfilled in the Area 5 RWMS in shallow, unlined land disposal trenches and pits. Six unclassified and four classified pits and trenches have received waste since the implementation of DOE Order 5820.2A (Figure 2.10). Seven pits and trenches active since 1988 remain open and are available to receive waste (Table 2.2). Pit 6 (P06U) has 
Table 2.2 Operational Status and Dimensions of Shallow Pits and Trenches at the Area 5 RWMS

\begin{tabular}{|c|c|c|c|c|c|c|c|}
\hline Disposal Unit & $\begin{array}{l}\text { Date } \\
\text { Opened }\end{array}$ & Date & Status & $\begin{array}{c}\text { Assessment } \\
\text { Process }\end{array}$ & $\begin{array}{l}\text { Max } \\
\text { Length } \\
\text { (m) }\end{array}$ & $\begin{array}{l}\text { Max } \\
\text { Width } \\
\text { (m) }\end{array}$ & $\begin{array}{l}\text { Mean } \\
\text { Depth } \\
\text { (m) }\end{array}$ \\
\hline T01U & $01 /-/ 1961$ & $07 /-/ 1965$ & Closed & $\mathrm{CA}$ & 85.4 & 18.6 & 4.6 \\
\hline T06U & $05 /-/ 1965$ & $02 /-/ 1970$ & Closed & $\mathrm{CA}$ & 189.4 & 12.3 & 4.6 \\
\hline T07U & $09 / 04 / 1968$ & $12 / 21 / 1987$ & Closed & $\mathrm{CA}$ & 204.7 & 12.9 & 4.6 \\
\hline $\mathrm{T} 04 \mathrm{U}$ & $02 /-/ 1970$ & $12 /-/ 1978$ & Closed & $\mathrm{CA}$ & 192.0 & 15.1 & 4.6 \\
\hline $\mathrm{T} 02 \mathrm{U}$ & $12 /-/ 1972$ & $12 /-/ 1978$ & Closed & $\mathrm{CA}$ & 192.9 & 15.1 & 4.6 \\
\hline $\mathrm{P} 01 \mathrm{U}$ & $11 / 01 / 1978$ & $04 / 18 / 1985$ & Closed & $\mathrm{CA}$ & 195.9 & 74.6 & 8.5 \\
\hline $\mathrm{T} 03 \mathrm{U}$ & $-/-/ 1984$ & $10 / 15 / 1996$ & Closed & PA & 192.1 & 13.8 & 4.6 \\
\hline $\mathrm{P} 02 \mathrm{U}$ & $04 / 24 / 1985$ & $01 /-/ 1987$ & Closed & $\mathrm{CA}$ & 25.3 & 30.3 & 7.6 \\
\hline $\mathrm{P} 03 \mathrm{U}$ & $01 /-/ 1987$ & & Open & $\mathrm{CA} / \mathrm{PA}$ & 256.0 & 105.5 & 9.1 \\
\hline $\mathrm{P} 04 \mathrm{U}$ & $06 / 21 / 1988$ & $05 / 11 / 1995$ & Closed & $\mathrm{CA} / \mathrm{PA}$ & 304.8 & 61.0 & 6.1 \\
\hline P06U Upper & $-/-/ 1994$ & & Open & PA & 190.0 & 30.0 & 7.4 \\
\hline P06U Lower & $-/-/ 1994$ & & Open & PA & 183.0 & 6.0 & 14.6 \\
\hline $\mathrm{P} 05 \mathrm{U}$ & $02 / 23 / 1995$ & & Open & PA & 304.8 & 45.7 & 6.7 \\
\hline $\mathrm{P} 07 \mathrm{U}$ & $02 /-/ 1997$ & & Open & PA & 75.0 & 11.1 & 6.7 \\
\hline T01C & $-/-/ 1960$ & $03 /-/ 1969$ & Closed & $\mathrm{CA}$ & 186.4 & 12.0 & 4.6 \\
\hline T03C & $-/-/ 1960$ & $03 /-/ 1969$ & Closed & $\mathrm{CA}$ & 186.2 & 12.0 & 4.6 \\
\hline T05C & $-/-/ 1960$ & $03 /-/ 1969$ & Closed & $\mathrm{CA}$ & 117.6 & 12.0 & 4.6 \\
\hline T06C & $-/-/ 1960$ & $03 /-/ 1969$ & Closed & $\mathrm{CA}$ & 117.0 & 12.2 & 4.6 \\
\hline T04C & $03 /-/ 1969$ & $08 / 03 / 1995$ & Closed & $\mathrm{CA} / \mathrm{PA}$ & 205.7 & 17.5 & 6.1 \\
\hline T04C-1 & $03 /-/ 1969$ & $08 / 03 / 1995$ & Closed & $\mathrm{CA} / \mathrm{PA}$ & 57.9 & 9.7 & 4.6 \\
\hline T02C & $12 / 05 / 1988$ & $7 / 22 / 1993$ & Closed & PA & 117.3 & 10.7 & 6.1 \\
\hline T07C & $-/-/ 1995$ & & Open & PA & 195.1 & 15.2 & 4.6 \\
\hline T08C & $-/-/ 1995$ & & Open & PA & 129.5 & 15.2 & 4.6 \\
\hline T09C & $-/-/ 1995$ & & Open & PA & 88.4 & 9.1 & 4.6 \\
\hline
\end{tabular}

- Month or day uncertain. 
Table 2.3 Operational Status of GCD Boreholes at the Area 5 RWMS. The GCD boreholes have a diameter of 3.0 to $3.6 \mathrm{~m}(10$ to $12 \mathrm{ft}$ ) and thickness of $15 \mathrm{~m} \mathrm{(49} \mathrm{ft)} \mathrm{and} \mathrm{a} \mathrm{total} \mathrm{volume} \mathrm{of}$ 106 to 161 cubic meters $\left(\mathrm{m}^{3}\right)\left(3.7 \mathrm{e} 3\right.$ to $5.7 \mathrm{e} 3$ cubic feet $\left.\left[\mathrm{ft}^{3}\right]\right)$.

\begin{tabular}{|c|c|c|c|c|c|}
\hline GCD Borehole & Disposal Area & Date Opened & Date Closed & Status & $\begin{array}{l}\text { Assessment } \\
\text { Process }\end{array}$ \\
\hline U5RWMS01C & Classified & $-/-/ 1984$ & $-/-/ 1984$ & Closed & CA/40 CFR $191 \mathrm{PA}$ \\
\hline U5RWMS02C & Classified & $-/-/ 1984$ & $-/-/ 1984$ & Closed & CA/40 CFR $191 \mathrm{PA}$ \\
\hline U5RWMS03C & Classified & $-/-/ 1984$ & $-/-/ 1984$ & Closed & CA/40 CFR $191 \mathrm{PA}$ \\
\hline U5RWMS04C & Classified & $07 / 19 / 1985$ & $01 / 14 / 1987$ & Closed & CA/40 CFR $191 \mathrm{PA}$ \\
\hline U5RWMS05U & Unclassified & $02 / 05 / 1986$ & $04 / 08 / 1987$ & Closed & $\mathrm{CA}$ \\
\hline U5RWMS06U & Unclassified & $07 / 16 / 1986$ & & Open (Inactive) & $\mathrm{CA}$ \\
\hline U5RWMS07C & Classified & $07 / 07 / 1989$ & & Open (Inactive) & $\mathrm{CA} / 5820.2 \mathrm{~A} \mathrm{PA}$ \\
\hline U5RWMS08C & Classified & $-/-/ 1987$ & & Open (Empty) & None Applicable \\
\hline U5RWMS09U & Unclassified & $-/-/ 1987$ & & Open (Empty) & None Applicable \\
\hline U5RWMS010U & Unclassified & $12 / 11 / 1987$ & $11 / 03 / 1989$ & Closed & $\mathrm{CA} / 5820.2 \mathrm{~A} \mathrm{PA}$ \\
\hline U5RWMS011U & Unclassified & $-/-/ 1989$ & & Open (Empty) & None Applicable \\
\hline U5RWMS012U & Unclassified & $-/-/ 1989$ & & Open (Empty) & None Applicable \\
\hline $\begin{array}{c}\text { Greater } \\
\text { Confinement } \\
\text { Disposal Test } \\
\text { (GCDT) }\end{array}$ & Unclassified & $-/-/ 1983$ & $-/-/ 1984$ & Closed & $\mathrm{CA}$ \\
\hline
\end{tabular}

- Month or day uncertain.

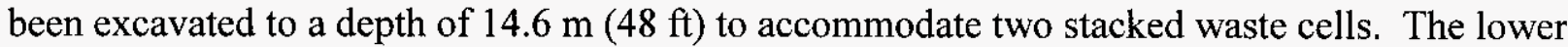
cell is being filled with thorium waste. Thorium waste is disposed at greater depth to reduce the potential for human and biological intrusion and to attenuate the flux of ${ }^{222} \mathrm{Rn}$. Pits and trenches active since 1988 and their approximate dimensions are listed in Table 2.2. All other pits and trenches indicated in the Area 5 RWMS (Figure 2.10) were filled prior to 1988 and are awaiting final closure.

\subsubsection{Types of Containers}

The waste containers disposed at the site have varied significantly in strength and integrity over time. The available data bases classify the containers as boxes, drums, or nonstandard. Containers other than standard-sized boxes and drums are classified as nonstandard. Numerous nonstandard containers have been disposed at the site, including specialized containers of 
unusual shapes or boxes or drums of nonstandard sizes. Boxes have been constructed of cardboard, plywood, or steel. The type of box was not differentiated in the records prior to 1992. Between 1978 and 1992, 783,000 boxes were disposed at the site. Cardboard triwall boxes, which are cardboard containers set on wooden pallets, banded with steel strapping, were commonly used prior to the mid-1980s. Contents of these boxes were contained within plastic bags. Cardboard boxes were approximately 0.6 or $1.2 \mathrm{~m} \mathrm{(2} \mathrm{or} 4 \mathrm{ft})$ high and were susceptible to crushing if stacked too high. Plywood boxes were delivered in sizes ranging from $2 \mathrm{ft} \times 4 \mathrm{ft} \times$ $8 \mathrm{ft}$ to $4 \mathrm{ft} \times 8 \mathrm{ft} \times 8 \mathrm{ft}$. Wooden pallets or dunnage were used to allow handling with forklifts. Steel boxes are in more general use in the 1990s and are standardized in sizes of $4 \mathrm{ft} \times 4 \mathrm{ft} \times 7 \mathrm{ft}$ or $2 \mathrm{ft} \times 4 \mathrm{ft} \times 7 \mathrm{ft}$. Steel feet or forklift slots are typically incorporated into the box design.

Several sizes of drums have been used for disposal at the site, including 55 -gallon drums $\left(8 \mathrm{ft}^{3}\right)$, 83-gallon (13.9 $\left.\mathrm{ft}^{3}\right)$ overpack drums, and large ten-drum overpack containers (jet engine afterburner cases). Between 1978 and 1992, 6 million drums were disposed at the site.

\subsubsection{Placement of Containers}

Waste containers are stacked in the disposal trenches to a height about $1.2 \mathrm{~m}(4 \mathrm{ft})$ below original grade. Plywood and steel boxes are typically stacked as tightly as practicable (several inches of separation), and octagonal triwall cardboard boxes, no longer in use, were stacked as close as the underlying pallets allowed. At various times, drums have been placed vertically on pallets (four drums on a pallet) or on their sides in either a square array (rows and columns) or nested in a triangular array. Nonstandard containers are typically stacked to make best use of available pit volume.

Dunnage, blocking, and other packing materials required for delivery and disposal of waste have typically been placed in the excavations with the waste. Typically, both wooden dunnage and blocking and steel strapping material were disposed in the narrow gap between the trench wall and the stacked waste. Any volume above the debris is typically filled with drums, as available.

\subsubsection{Temporary Closure Cap for Pits and Trenches}

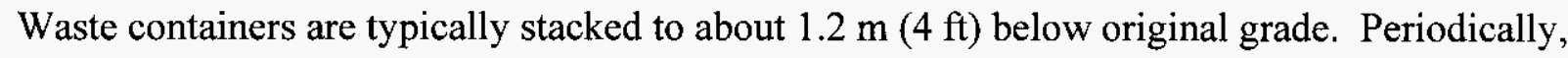
soil backfill is pushed over the waste in a single lift with a bulldozer. The placed fill layer is approximately $2.4 \mathrm{~m}(8 \mathrm{ft})$ thick, which provides a final grade about $1.2 \mathrm{~m}(4 \mathrm{ft})$ above original ground elevation. The upper portion of the soil cap is compacted in place. This cover is referred to as a temporary closure cap or operational cover because the native material is applied routinely over the filled portions of waste disposal cells.

Prior to 1993, general soil fill was placed as backfill. The natural materials at the site contain cobbles up to about $20 \mathrm{~cm}(8 \mathrm{in})$ in diameter. Because the spacing between containers is typically much smaller than $20 \mathrm{~cm}$ (8 in), bridging of voids is likely. Since 1993, backfill soils 
have been scalped of material over 5 to $8 \mathrm{~cm}$ ( 2 to $3 \mathrm{in}$ ) in diameter to reduce the bridging potential of the soil cover and to promote filling of the voids between containers with soil, resulting in a reduction in observed subsidence. A bronze plate on top of each corner monument records the cell number, the survey coordinates, and the date the cell was opened and closed. The temporary closure cap will remain until final closure.

Settlement of the temporary closure cap, which is observed periodically, can be attributed to soil filling the voids between containers or possible collapse of containers. Photographs from 1982 indicate subsidence is an ongoing process. Observed subsidence has historically varied from shallow depressions (up to $6 \mathrm{~m}[20 \mathrm{ft}]$ in diameter), to $1.5-\mathrm{m}$ - (5-ft)-deep open cracks.

Depressions and cracks, as they form, are filled with soil and regraded by site personnel. The areas or extent of subsidence have not typically been recorded. Presently, areal depressions of about a foot in the soil cover are common over the trench and pit areas.

\subsubsection{Mixed Waste Disposal}

Pit 3 (P03U) is the only shallow land burial unit in the Area 5 RWMS that has received MW. Disposal of low-level (nonhazardous) waste began in Pit 3 in January 1987. Mixed wastes were disposed in Pit 3 for the first time in September 1987, when the state of Nevada granted Pit 3 interim status under the Resource Conservation and Recovery Act (RCRA). The MW stream placed in Pit 3 during this early period of operation was a solid concrete form known as pondcrete generated by the Rocky Flats Plant. Pit 3 has received MW from both on site and off site generators. The DOE is pursuing RCRA permitting of a new MWMU to be located directly north of the LLWMU.

\subsubsection{Greater Confinement Disposal}

In 1980, the DOE's National LLW Management Program began reviewing alternatives to shallow land burial of LLW. Although the majority of LLW is routinely and safely disposed using shallow land burial, a portion of the waste was considered unsuitable for shallow land burial because of its high-specific activity or potential for migration into biopathways. The project was also designed to substantially reduce the potential for biointrusion and inadvertent human intrusion. In 1981, DOE/NV began a project to demonstrate the feasibility of greaterdepth burial in vertical boreholes drilled in the alluvial sediments. The first unit was experimental and is known as GCD Test or GCDT. Subsequent boreholes are referred to as GCD boreholes.

The GCD and GCDT boreholes are unlined, except for the upper $3 \mathrm{~m}(10 \mathrm{ft})$ which are cased with a corrugated steel culvert. Each is approximately 3 to $3.6 \mathrm{~m}$ (10 to $12 \mathrm{ft}$ ) in diameter, with a total depth of $36 \mathrm{~m}(118 \mathrm{ft})$. Waste packages are placed in the bottom of the GCD boreholes to approximately $21 \mathrm{~m}(70 \mathrm{ft})$ below the land surface. The holes are then backfilled with native soil. A 1.8-m- (6-ft)-long concrete monument, indicating the location and contents of the borehole, is placed approximately $1.5 \mathrm{~m}(5 \mathrm{ft})$ below the surface in each hole. Waste disposed in 
GCD boreholes includes LLW, TRU including nuclear weapon accident residues, high-specific activity tritium waste, and similar to greater-than-class $\mathrm{C}$ waste that includes such wastes as irradiated fuel rod cladding, sealed sources, and radioisotope thermoelectric generators.

GCD boreholes were used for the disposal of waste from 1983 through 1989. Thirteen GCD boreholes were developed during this period within the LLWMU (Figure 2.10). Seven cells have been filled and operationally closed. Two GCD boreholes have received waste and remain open; four GCD cells are empty. Table 2.3 lists the GCD boreholes and their status. GCD boreholes have been designated with sequential numbers and a one-letter code denoting their classification status. 
This Page Intentionally Left Blank 


\subsection{DATA QUALITY OBJECTIVES}

The DQO process is a method for determining the type, quantity, and quality of data required to make environmental management decisions (U.S. Environmental Protection Agency [EPA], 1994). It has been used primarily to design environmental sampling programs. The DQO process can still be applied to define the decisions to be made and the types of data needed to complete this initial CA. The seven steps of the DQO process are:

- Step 1: State the Problem - Concisely describe the problem to be studied. Review prior studies and existing information to gain a sufficient understanding to define the problem.

- Step 2: Identify the Decision - Identify what questions the study will attempt to resolve, and what actions may result.

- Step 3: Identify the Inputs to the Decision - Identify the information that needs to be obtained and the measurements that need to be taken to resolve the decision statement.

- Step 4: Define the Study Boundaries - Specify the time periods and spatial area to which decisions will apply. Determine when and where data should be collected.

- Step 5: Develop a Decision Rule - Define the statistical parameter of interest, specify the action level, and integrate the previous DQO outputs into a single statement that describes the logical basis for choosing among alternative actions.

- Step 6: Specify Tolerable Limits on Decision Errors - Define the decision maker's tolerable decision error rates based on a consideration of the consequences of making an incorrect decision. A decision error rate is the probability of making an incorrect decision based on data that inaccurately estimate the true state of nature.

- Step 7: Optimize the Design - Evaluate information from the previous steps and generate alternative data collection designs. Choose the most resource-effective design that meets all DQOs.

Based on CA preparation guidance (DOE, 1996b), it is assumed that new samples will not be collected to prepare this initial CA. Because the relationship between the input data (e.g., radionuclide inventory) and the performance measure (e.g., radiological dose) is poorly known, it is difficult to quantitatively determine the level of uncertainty tolerable in the input data or to optimize data collection activities. Therefore, only the first five steps of the DQO processes have been applied. Once the TEDE is estimated and the sensitivity of the initial CA models known, sensitive parameters and cost-effective approaches for reducing their uncertainty can be identified if necessary. The DQO process was completed with input from NNSA/NV and BN personnel in the Waste Management, Environmental Restoration, and Environment, Safety, and Health divisions. 


\subsection{Results of Data Quality Objectives Process}

\subsubsection{Step 1: Statement of the Problem}

The NTS has been used for a variety of activities that have left residual radioactive material in soil and groundwater. Future users of the lands now within the NTS boundary will receive radiological doses from all sources of residual radioactive material left behind by DOE operations. Reasonable assurance is required that continuing operation of the Area 5 RWMS does not present an unreasonable risk to the health and safety of the public, considering all interacting sources of residual contamination.

\subsubsection{Step 2: Identification of the Decision}

This initial CA is assumed to be a decision tool for waste management. Its purpose is to determine if continuing operation of the Area 5 RWMS poses an unreasonable risk to the health and safety of the public considering all interacting sources of residual contamination. If reasonable assurance of protection cannot be provided, the CA can be used to select cost- effective options that would make the risk from all interacting sources of contamination acceptable. Options may include further data collection and data analysis, implementation of land-use controls, revision of waste acceptance criteria, and remediation of contamination.

\subsubsection{Step 3: Identify Inputs to the Decision}

The primary input required for the decision is the TEDE estimated for 1,000 years after closure at the point accessible to the public where the maximum dose is expected. Estimation of the TEDE requires knowledge of the sources that may contribute to the dose. The source data required are the activity, concentration, and spatial distribution of individual radionuclides from DOE operations in Frenchman Flat and surrounding areas that could impact a receptor. The locations and extent of all significant sources of residual contamination are believed to be known from the operational history of the site, radiological field surveys, and aerial radiation surveys. Major sources of residual near-surface contamination have been characterized by the Nevada Applied Ecology Group (NAEG) and the Radionuclide Inventory and Distribution Program (RIDP). Data sources for the LLW inventory include generator process knowledge, generator shipping records, and Waste Management data base records.

Because it is assumed that the initial CA's purpose is to assess the impacts of continuing waste management operations, the $\mathrm{CA}$ assesses the impacts from all residual sources of contamination at locations where the Area 5 RWMS waste inventory makes a significant contribution to the dose. This is consistent with CA guidance which states that "... the CA will estimate the potential cumulative impacts ... from the active or planned LLW disposal facility and other sources of radioactive material ... that may interact with the LLW disposal facility (not all sources of radioactive material on a DOE site, but all of those that could interact with the LLW facility)" (DOE, 1996b). 
The results of the Area 5 PA indicate that the TEDE beyond the Frenchman Flat boundary is likely to be negligible. Therefore, interacting source terms should be limited to those that can cause a dose to a resident within Frenchman Flat.

Data describing the geological and biological environments is also required to develop conceptual and mathematical models of radionuclide transport. Finally, information concerning how the land and existing source terms are managed and regulated is also necessary.

\subsubsection{Regulatory Drivers}

The sources of residual radioactive material on the NTS are regulated under various DOE, federal, and state regulations (Table 3.1). These regulations are important to the CA processes because they will affect how these sources will be managed and closed in the future.

The CA assesses the potential for compliance with the 100-mrem annual public dose limit set by DOE Order 5400.5. The CA also requires that an options analysis be performed if the annual TEDE exceeds the 30 -mrem dose constraint.

Low-level radioactive wastes disposed after September 26, 1988, are regulated under DOE Order 5820.2A. The hazardous component of mixed wastes disposed in the Pit $3 \mathrm{MW}$ disposal unit (P03U) are regulated under RCRA. Transuranic wastes disposed in GCD boreholes and inadvertently in Trench 4 (T04C) are regulated under Title 40 CFR 191, "Environmental Radiation Protection Standards for Management and Disposal of Spent Nuclear Fuel, High-Level, and Transuranic Wastes," (EPA, 1985). This standard contains specific closure requirements for active and passive institutional controls, monitoring, markers and records, engineered and natural barriers, siting requirements, and provisions for future removal of the waste if deemed necessary.

The state of Nevada Division of Environmental Protection (NDEP), regulates the hazardous waste component of mixed waste disposal at the NTS under RCRA. The Pit $3 \mathrm{MW}$ disposal unit (P03U) at the Area 5 RWMS has been operated by DOE/NV under the conditions of RCRA Interim Status since September 1987. DOE/NV recently resubmitted the RCRA Part B Permit Application (including a closure and postclosure care plan) to NDEP to request a RCRA permit for the Pit $3 \mathrm{MW}$ unit. Pit 3 will be closed with a RCRA-equivalent closure cover. The groundwater beneath the Area 5 RWMS has been monitored at three wells for RCRA compliance since 1993.

The FFACO between the state of Nevada, the DOE, and the DoD is the primary regulatory driver for DOE environmental restoration activities in Nevada (DOE, 1996e). The corrective action strategy in the FFACO includes four steps: (1) identify CASs, (2) group the CASs into CAUs, (3) prioritize the CAUs for funding and work, and (4) implement the corrective action investigations (CAIs) and/or corrective actions, as applicable. Based on the source of contamination, CASs have been organized into four categories: (1) Industrial Sites, (2) UGTA sites, (3) Soil Sites, and (4) Off Sites. The first three categories of sources are pertinent to the CA for the Area 5 RWMS facility and are briefly summarized in the next section. 


\section{Table 3.1 Regulatory Drivers for DOE Operations at the NTS}

\begin{tabular}{|c|c|}
\hline DUE Urders & Overview \\
\hline $\begin{array}{l}\text { DOE - 5400.1, General Environmental Protection } \\
\text { Program (issued 11-09-1988) }\end{array}$ & $\begin{array}{l}\text { Establishes environmental protection program requirements, authorities, and } \\
\text { responsibilities for DOE operations for assuring compliance with applicable } \\
\text { federal, state, and local environmental protection laws and regulations. }\end{array}$ \\
\hline $\begin{array}{l}\text { DOE - } 5400.5 \text {, Radiation Protection of the Public and } \\
\text { the Environment }\end{array}$ & $\begin{array}{l}\text { Establishes standards and requirements for operations of the DOE and DOE } \\
\text { contractors with respect to protection of members of the public and the } \\
\text { environment against undue risk from radiation. }\end{array}$ \\
\hline $\begin{array}{l}\text { DOE - 5820.2A, Radioactive Waste Management } \\
\text { (issued 09-26-1988) }\end{array}$ & $\begin{array}{l}\text { Establishes policies, guidelines, and minimum requirements by which DOE } \\
\text { manages its radioactive and mixed waste facilities. }\end{array}$ \\
\hline $\begin{array}{l}\text { Federa and State Statues, Regulations, Permits, and } \\
\text { Agreements }\end{array}$ & Overview: \\
\hline Title 40 CFR 58, Appendix E & Operational standards for air particulate monitoring. \\
\hline $\begin{array}{l}\text { Title } 40 \text { CFR } 61 \text {, Subpart H, National Standards for } \\
\text { Hazardous Air Pollutants (NESHAP) }\end{array}$ & $\begin{array}{l}\text { Establishes limits on hazardous pollutants, including radioactivity that may be } \\
\text { emitted into the atmosphere. }\end{array}$ \\
\hline $\begin{array}{l}\text { Title } 40 \text { CFR 141, National Primary Drinking Water } \\
\text { Regulations }\end{array}$ & $\begin{array}{l}\text { Controls discharges into groundwater through injection wells, wastewater } \\
\text { treatment and disposal sites, distribution of drinking water supplies, and } \\
\text { industrial and specific domestic septic tank disposal systems. }\end{array}$ \\
\hline $\begin{array}{l}\text { Title } 40 \text { CFR 191, Environmental Radiation Protection } \\
\text { Standards for Management and Disposal of Spent } \\
\text { Nuclear Fuel, High-Level, and Transuranic Radioactive } \\
\text { Wastes }\end{array}$ & $\begin{array}{l}\text { Establishes radiation protection standards governing the storage and disposal of } \\
\text { spent nuclear fuel, high-level, and transuranic waste. }\end{array}$ \\
\hline $\begin{array}{l}\text { RCRA (Title } 40 \text { CFR 264), Standards for Owners and } \\
\text { Operators of Hazardous Waste Treatment, Storage, and } \\
\text { Disposal Facilities }\end{array}$ & $\begin{array}{l}\text { Regulates the hazardous waste component of the mixed waste disposal at the } \\
\text { NTS under a state permit }\end{array}$ \\
\hline $\begin{array}{l}\text { RCRA (Title } 40 \text { CFR 265), Interim Status Standards for } \\
\text { Owners and Operators of Hazardous Waste Treatment, } \\
\text { Storage, and Disposal Facilities }\end{array}$ & $\begin{array}{l}\text { Regulates the hazardous waste component of the mixed waste disposal at the } \\
\text { NTS under a state permit for interim status facilities. }\end{array}$ \\
\hline $\begin{array}{l}\text { Nevada Administrative Code (NAC) } 445 \mathrm{~A} .450, \text { et seq. } \\
\text { Water Controls }\end{array}$ & $\begin{array}{l}\text { Establishes action levels, remediation standards, and conditions for terminating } \\
\text { remediation at contaminated groundwater sites. }\end{array}$ \\
\hline $\begin{array}{l}\text { Nevada Revised Statues (NRS) 534.110, Underground } \\
\text { Water and Wells }\end{array}$ & $\begin{array}{l}\text { Requires periodic statements of water elevations, water used, and acreage on } \\
\text { which water was used from all holders of permits and claimants of vested rights. }\end{array}$ \\
\hline NRS 445A.361 et seq., Public Water Systems & $\begin{array}{l}\text { Outlines the basic legal requirements of public water systems. Establishes the } \\
\text { policy of the state to provide water that is safe for drinking and other domestic } \\
\text { purposes. }\end{array}$ \\
\hline State General Permit GNEV93001 & $\begin{array}{l}\text { Regulates the ten usable sewage treatment facilities on the NTS. Issued by the } \\
\text { Nevada Division of Environmental Protection (NDEP). }\end{array}$ \\
\hline FFACO & $\begin{array}{l}\text { Agreement and consent order entered into by the state of Nevada acting by and } \\
\text { through the Department of Conservation and Natural Resources, NDEP; the } \\
\text { DOE; and the DoD. Addresses environmental restoration of historic } \\
\text { contaminated sites at the NTS and other sites in Nevada. Parties agree to } \\
\text { negotiate to address needed environmental restoration }\end{array}$ \\
\hline Agreement in Principle (AIP) & Outlines DOE's environmental monitoring commitments to the state of Nevada. \\
\hline
\end{tabular}

All environmental restoration closures at the NTS will follow the RCRA-like process outlined in the FFACO. There are no closures under the Comprehensive Environmental Response, Compensation, and Liability Act (CERCLA) at the NTS. The role of CERCLA at the NTS is limited to accepting CERCLA waste generated off site. In 1998, the EPA (Region IX) reviewed and approved the Area 3 and the Area 5 RWMSs for acceptance of CERCLA waste generated off site.

\subsubsection{Waste Management Projects}

A PA has been prepared and conditionally approved for the Area 5 RWMS (Shott et al., 1997a). Numerous reports describe the results of site characterization studies performed to support the 
Area 5 PA (Raytheon Services Nevada [RSN], 1991a,b; Reynolds Electrical \& Engineering Co., Inc [REECo], 1993a,b,c; Istok et al., 1994; Blout et al., 1995; Tyler et al., 1996). The site characterization field data and its interpretation provide values of model parameters and the site hydrologic conceptual model for this CA. The post- 1988 waste inventory was also estimated in the Area 5 PA. Additional PAs have been prepared for the Area 3 RWMS (Shott et al., 1997b) and TRU disposed in the GCD boreholes at the Area 5 RWMS (Baer et al., 1994).

The conceptual model of radionuclide transport for the Area 5 RWMS assumes that radionuclide release is dominated by upward pathways, which release radionuclides to soil and vegetation above the site. Resuspension and atmospheric advection is assumed to transport contamination from the cap to off-site locations. The groundwater pathway is not a credible pathway under the current climate and undisturbed conditions. A bounding analysis was performed in the Area 5 RWMS PA to evaluate the impacts of a groundwater pathway assuming complete subsidence and flooding. The bounding analysis demonstrated that transport to the groundwater may occur if several low-frequency flooding events are combined with uniform subsidence of the entire site. The recharge of the uppermost aquifer due to flooding of the subsided site was shown to be possible within about 140 years following three 200 -year frequency storm events over a 3 -year period. The groundwater radionuclide concentrations and consequent dose impacts to a receptor drinking water from a water supply well in the uppermost aquifer were evaluated and shown to be within the drinking water standards specified in 40 CFR 141, "National Primary Drinking Water Regulations" (EPA, 1998). The results of the Area 5 RWMS PA indicate that the highest TEDE is expected at the site boundary and that the TEDE is very likely less than 25 mrem in a year. The results indicate that doses from the Area 5 RWMS are likely to be negligible beyond the boundaries of Frenchman Flat. The TEDE from atmospheric transport of radionuclides to Cane Spring, on the perimeter of Frenchman Flat, is estimated to be less than $1 \mathrm{e}-3 \mathrm{mrem} / \mathrm{yr}$. Therefore, source terms interacting with the Area 5 RWMS are assumed to be limited to sources that could cause doses to a receptor in the Frenchman Flat basin.

A panel of independent SMEs has evaluated the effectiveness and probable duration of long-term institutional controls in Frenchman Flat through formal elicitation (Black et al., 1998).

Elicitation was used to assess quantile values from the SMEs using standard methods of expert judgement. The SME consensus opinion supports the conclusion that there is a 50 percent probability that active institutional controls will continue for up to 250 years in Frenchman Flat. The basis of the SME opinion lay primarily in the integrity of the oral record and physical evidence of long term, widespread underground nuclear testing (i.e., radiological contamination, surface subsidence craters, and structural remnants).

The SMEs also considered physical deterrents (i.e., placards, markers, surface and subsurface barriers, etc.) and their effectiveness for reducing the probability of human intrusion into waste . Little credit and effectiveness were given to physical deterrents because (1) placards and markers are unlikely to maintain their intended meaning in the future, and (2) the SMEs believed that cost-effective surface and subsurface barriers cannot be designed or constructed. Consequently, the 250-year institutional control period is attributed to active control measures, site knowledge, and the oral record of historical uses at the NTS. 


\subsubsection{Environmental Restoration Program}

Historically contaminated areas on the NTS will be remediated and closed by the environmental restoration program. The three classes of CAUs identified in the FFACO are Industrial Sites, UGTA sites, and Soil Sites.

Industrial Sites - The FFACO identifies approximately 1,150 industrial sites where activities were conducted that supported nuclear testing activities. The functional categories of these CASs range from landfills, mud pits, and leachfields, with or without radiological contamination, to discarded or abandoned materials such as drums, batteries, and lead materials. CASs with materials that are easily disposed are considered to be housekeeping sites and account for approximately one-third of all Industrial Site CASs. The radionuclide source inventories at the Industrial Sites have not been identified at this time; however, they are believed to be negligible compared to soil sites. Therefore, Industrial Sites are not considered in this CA.

Underground Test Areas - The FFACO identifies 908 historical nuclear detonations which occurred in shafts or tunnels at the NTS. They are categorized into 878 CASs which are grouped into six geographically distinct CAUs. Each UGTA CAU has different contaminant sources and geologic and hydrogeologic characteristics related to its location. The Yucca Flat UGTA CAU consists of 717 CASs. The other UGTAs are the Frenchman Flat (10 CASs), Western Pahute Mesa (18 CASs), Central Pahute Mesa (64 CASs), Rainier Mesa/Shoshone Mountain (66 CASs), and Climax Mine (3 CASs).

Neither the Yucca Flat CAU nor the Climax Mine CAU will contribute groundwater recharge of radiological source influence to the Area 5 RWMS during the 1,000-year CA period because of long transport times (DOE, 1997b). The other CAUs located west and northwest of Yucca Flat are within different groundwater subbasins of the regional Death Valley flow system. Therefore, all other UGTA CAUs are either hydrologically disconnected from the Frenchman Flat UGTA or will not interact within the 1,000-year compliance period.

The objective of the UGTA CAIs is to define contaminant boundaries around each CAU where groundwater may be unsafe for domestic and municipal use. The contaminant boundary is drawn to bound groundwater capable of causing a median dose of $4 \mathrm{mrem} / \mathrm{yr}$ within a 1,000-year period. Regional groundwater flow and tritium transport modeling has been performed to provide an initial basis for assessing flow paths from the CAUs (DOE, 1997b). A second phase of the CAI process will refine the CAU boundaries through CAU-specific models with site-specific data. Closure activities under UGTA will be accomplished through 2014 (DOE, 1996e).

The implementation of the Frenchman Flat CAI is in progress, following a CAI Plan (DOE, $1999 \mathrm{~b}$ ). The CAI was planned using the DQO process and a value of information analysis to support the process. The CAI to date has generated a draft conceptual flow and transport model for Frenchman Flat. An external review of the draft Frenchman Flat CAU model was performed by a panel of SMEs (IT, 1999). The SMEs concluded that the draft Frenchman Flat CAU flow 
and transport model is flawed, and consequently, that the model results are unreliable. The reviewers specifically noted that large uncertainties remain in the source inventory, the radionuclide release rates from the rock matrix, the site hydrostratigraphy, the flow direction and rate, and the transport parameters (IT, 1999). The UGTA Program is in the process of acquiring additional site characterization data to address the uncertainties identified during the peer review.

Because of the uncertainty surrounding the Frenchman Flat UGTA, this version of the CA will not include an estimate of the dose from contaminated groundwater in Frenchman Flat. The groundwater dose and its distribution in Frenchman Flat cannot be reliably quantified at this time. Therefore, reasonable assurance of compliance with the CA dose limit and dose constraint cannot currently be demonstrated at the Area 5 RWMS site boundary because of the uncertainty in the groundwater dose from historical underground testing.

Under the CA guidance, such a finding requires selection of a management option though an options analysis. The management of the UGTA CAUs, however, is subject to the FFACO. Options for remediation and closure of the UGTAs must be negotiated with the state of Nevada and are subject to stakeholder input and external peer review. Consequently, the management option for the Frenchman Flat UGTA has been selected by the UGTA Program with oversight by the state of Nevada. Remediation of the Frenchman Flat UGTA is assumed to be infeasible and the CAI is expected to define contaminant boundaries where public access will be restricted indefinitely. In the next iteration of the CA, completed under the Maintenance Program, the CAU contaminant boundaries will be identified. The next iteration of the CA will be performed when (1) the Frenchman Flat CAU model is approved and accepted under the FFACO; and/or (2) significant changes in DOE policy regarding resource management, stewardship, or land-use withdrawal occur which deviate from those assumed and summarized in the CA and its supporting documents.

Despite the general uncertainty in estimating the areal distribution and migration of radionuclides in Frenchman Flat groundwater, four active water supply wells and three RCRA monitoring wells around the Area 5 RWMS show no contamination related to waste disposal or underground nuclear testing. To assure the continuing high quality of the groundwater resources, the Nevada Test Site Resource Management Plan (DOE, 1998a) specifies a goal to "maintain the quality of waters that are presently clean." This goal is explicitly tied to compliance with federal and state water quality standards and proper disposal of low-level radioactive waste. In addition, NTS procedures require that a Site Use and Development Board evaluate all activities proposed for the NTS. The Board, among other things, evaluates the activity for its potential to contaminate surface and subsurface water. Taken together, the NTS resource management policies combined and the existing clean status of most of the water underlying Frenchman Flat (exclusive of UGTA CASs) assure the future quality of the groundwater resource.

Soil Sites - Soil Site CAUs consist of surface and shallow subsurface soil contamination resulting from various types of nuclear experiments or testing. The FFACO identified the following types of CAUs: 
- Atmospheric testing sites (including airburst, airdrop, balloon, rocket, surface, and tower types);

- Safety experiments sites that produced no nuclear explosions, but created surface contamination;

- Cratering test sites where nuclear devices were used to excavate large volumes of earth; and

- Nuclear rocket engine test sites.

Corrective actions will be performed at surface and subsurface Soil Sites. Remedies for surface soils will include removal of hot spots. Subsurface site remedies will range from clean closure to closure in place. Soil Site CAUs are included in the CA, assuming no remediation, as definite cleanup standards have not been developed.

\subsubsection{Environmental Monitoring}

Routine radiological environmental monitoring and environmental surveillance on and off the NTS are described in the Routine Radiological Environmental Monitoring Plan (RREMP) (BN, 1998). Derived through the DQO process and integrating all previous monitoring efforts, the plan was prepared in 1998 by a team of scientists from NNSA/NV, BN, IT, Desert Research Institute (DRI), and the Joint Testing Organization (JTO). The RREMP addresses compliance with DOE Orders 5400.1, 5400.5, and applicable federal and state regulations listed in Table 3.1, and stakeholder issues. It will be reviewed annually and updated biannually as required.

On-site and off-site environmental surveillance and monitoring results are published annually in the Annual Site Environmental Report (ASER) for the NTS. The 1998 ASER indicates that all DOE operations complied with the applicable DOE, state, and federal regulations in 1998 (DOE, $1999 \mathrm{c}$ ). There was no indication of migration of radioactivity through groundwater off site.

Surveillance around the NTS showed that there was no significant airborne radioactivity off site due to atmospheric emissions, evaporation of liquid effluents, or resuspension of soil. The effective dose equivalent to the maximally exposed member of public off site at the NTS boundary was calculated to be $0.13 \mathrm{mrem}$, based on the results of the 1998 NTS emissions and monitoring data. The RCRA Groundwater Monitoring report summarizes the results of RCRA detection monitoring conducted at the Area 5 RWMS. Operation of the Area 5 RWMS has had no detectable impact on the uppermost aquifer.

The environmental monitoring program at the Area 5 RWMS routinely monitors the vadose zone for water content and air, soil, groundwater, and biota for radionuclides. In addition to radionuclides, the uppermost aquifer beneath the RWMS is monitored for hazardous constituents to satisfy RCRA requirements for the MW disposed in Pit 3. Groundwater monitoring results to date show no indication that hazardous or radioactive waste constituents have reached groundwater (DOE, 1999c). Tritium is the only man-made radionuclide routinely detected at the Area 5 RWMS in media other than groundwater (DOE, 1999c). 


\subsubsection{Resource Management}

The current and future land-use planning for the NTS is described in the EIS (DOE, 1996c). The EIS considers four resource management alternatives: Continue Current Operations (No Action Alternative), Discontinue Operations, Expanded Use, and Alternative Use of Withdrawn Lands. The record of decision (ROD), issued in December 1996 (DOE, 1996d), states that most activities at the NTS will be pursued at levels described by the Expanded Use Alternative; and that low-level and mixed waste management activities will continue at levels described by the No Action Alternative. Low-level and mixed waste management activities may be reconsidered pending decisions by DOE under the Final Waste Management Programmatic Environmental Impact Statement (WMPEIS) (DOE, 1997c). The WMPEIS will include national policy decisions concerning the treatment, storage, and disposal of LLW, MW, and TRU across the DOE complex.

The implementation of the EIS is being achieved through the Resource Management Plan (DOE, 1998a). The ROD's land-use map identifies three zones of land usage within the Frenchman Flat: Reserve Zone; Research, Test, and Experiment Zone; and Radioactive Waste Management Zone.

An integrated approach to resource management is being pursued by DOE/NV through two recent initiatives: (1) Site Use and Development process, and (2) Accelerating Cleanup: Paths to Closure Plan (DOE, 1999a). DOE/NV has set up a Site Use and Development (SUD) board, made up of senior DOE/NV officials and National Laboratory representatives. The board's purpose is to review proposed projects on the NTS and make recommendations to the NNSA/NV manager. DOE/NV's Accelerating Cleanup: Paths to Closure Plan is an Environmental Management (EM) initiative, providing an integrated outlook of future Environmental Restoration and Waste Management Program activities. The initiative's objective is the remediation of the DOE complex by 2006. The plan also addresses how the Complex-wide activities may impact the EM mission resources at the NTS.

There are currently no plans to release lands within the NTS for public access. The current mission goals to preserve the capability to resume nuclear testing, support stockpile stewardship, and other national security missions require that public access to the site be restricted. Atmospheric and underground nuclear testing conducted in the past has created contamination areas that can not be released for public access. Therefore, the current boundaries of the NTS are expected to be maintained and public access is expected to be restricted into the foreseeable future.

\subsubsection{Step 4: Definition of the Study Boundaries}

Compliance with the 100 mrem dose limit and the 30 mrem dose constraint will be assessed for a period of 1,000 years after closure. Based on the Area 5 PA, closure is assumed to occur in 2028. Based on the elicitation of the expert panel, land-use controls are assumed to restrict 
public access to Frenchman Flat for a period of 250 years after closure. After 250 years, the point of compliance is assumed to be within the Frenchman Flat basin.

The inventory is assumed to be limited to sources that may contribute to the dose received by the public in Frenchman Flat. Sources interacting with the Area 5 RWMS within Frenchman Flat are assumed to be limited to those that occur within Frenchman Flat and Plutonium Valley. These sources lie within NTS operational Areas 5 and 11 and on the Nellis Air Force Range. The nearest sources outside Frenchman Flat are approximately $13 \mathrm{~km}(8 \mathrm{mi})$ to the north in Plutonium Valley and approximately $20 \mathrm{~km}(12 \mathrm{mi})$ to the north in Yucca Flat. The only pathway linking sites outside Frenchman Flat and the Area 5 RWMS is the atmospheric pathway. Only the Plutonium Valley soil site will be evaluated initially because it includes a relatively large and easily resuspended plutonium source term and is the source closest to the RWMS. If the Plutonium Valley soil site inventory is found to be insignificant, the Yucca Flat sources and other more remote sources are likely to be insignificant as well. The Plutonium Valley soil site is expected to be an insignificant source because current environmental monitoring data indicate that the dose from airborne plutonium is insignificant at the boundary of the Area 5 RWMS (DOE, 1997b).

\subsubsection{Step 5: Develop a Decision Rule}

The initial CA will determine if there is reasonable assurance that the TEDE from all residual sources of radioactive materials is less than $30 \mathrm{mrem}$ in a year for potential future residents of Frenchman Flat. Based on DOE guidance to use a best estimate of TEDE, the mean TEDE will be used for comparison with the dose constraint and dose limit. If the mean TEDE is less than $30 \mathrm{mrem}$ in a year at all locations, then a qualitative evaluation of ALARA requirements is all that is necessary. If the mean TEDE exceeds $30 \mathrm{mrem}$ in a year, then the CA will determine if there is reasonable assurance that the TEDE is less than $100 \mathrm{mrem}$ in a year. If there is reasonable assurance that the mean TEDE is less than $100 \mathrm{mrem}$ in a year, then a cost-effective management option will be selected that may reduce future doses. If there is not reasonable assurance that the TEDE is less than $100 \mathrm{mrem}$ in a year, then there may be a potential to exceed the DOE dose limits if no action is taken. Cost-effective corrective actions or additional data collection activities will be identified that may provide assurance of compliance with the 100 mrem in a year dose limit.

The primary purpose of the initial CA is to determine if there is reasonable assurance that continuing operation of the Area 5 RWMS does not pose an unacceptable risk. If the mean TEDE is less than 100 mrem in a year, it will be concluded that the CA provides reasonable assurance that continuing operations do not pose an unacceptable risk. The remaining steps of the DQO process are deferred to future iterations of the CA. 


\subsection{RADIONUCLIDE INVENTORIES}

This section describes the development of the radionuclide inventories located in Frenchman Flat and Plutonium Valley. Sources at these locations are considered most likely to interact with the Area 5 RWMS. The sources include contaminated soil sites created by various atmospheric tests involving nuclear material, UGTAs created by underground weapon tests, and the Area 5 RWMS. Simple and conservative analyses or justifications are provided to remove sources or individual radionuclides from the inventory that can be shown to have negligible impact on the dose. The inventory of the Frenchman Flat UGTA remains classified and is not evaluated in this CA. The Frenchman Flat UGTA will be evaluated in future revisions of the CA after additional site characterization and data analysis have been performed. A more detailed description of the inventory development process can be found in Appendix 1.

\subsection{Estimated Inventory of the Area 5 RWMS at Closure}

The Area 5 RWMS has operated from 1960 to the present and is assumed in this analysis to continue operations until closure in 2028. Waste is disposed in shallow pits and trenches, a deep trench (P06U) and, in the past, has been disposed in GCD boreholes. The inventory is conceptually divided into three categories corresponding to the shallow pits and trenches, the lower cell of P06U, and the GCD boreholes because of the different depths of burial for each category.

The inventory of radioactive materials disposed at the Area 5 RWMS can be estimated from generator reports, Waste Management data base records, and interviews of Waste Management personnel. The inventory expected to be disposed at the Area 5 RWMS between September 26, 1988, and closure in 2028 was previously estimated in the Area 5 RWMS PA (Shott et al., 1997a). The Area 5 RWMS PA includes an inventory for the shallow pits and trenches, which includes the post-1988 GCD inventory, and an estimated thorium inventory for the lower cell of P06U.

The inventory of waste disposed at the Area 5 RWMS from 1960 to September 26, 1988, is estimated in Appendix 1. Separate estimates are prepared for the shallow pits and trenches and GCD boreholes. The inventory was limited to radionuclides with half-lives greater than five years. Short-lived radionuclides decaying to long-lived progeny were converted into the activity of the long-lived progeny. An initial estimate of the inventory in the shallow pits and trenches was obtained from Waste Management data bases. Two data bases cover the periods of operation from 1960 to 1978 and 1978 to 1992 . These data are known to have considerable uncertainty and several potential sources of bias. The quality and reliability of the data has improved over time.

The waste characterization data obtained from the data bases can be inaccurate. The uncertainty in the true activity of a radionuclide in a waste was accounted for by randomly selecting a value from a loguniform distribution bounding the value reported by the generator. The distribution 
extends one order of magnitude above and below the value reported by the generator. Waste characterization errors were assumed to be 100 percent correlated among waste shipments characterized by a single generator. This assumption tends to maximize the uncertainty in the total activity disposed by an individual generator. Measurement errors among generators were assumed to be uncorrelated.

Incomplete waste characterization data may introduce biases into the inventory. Radionuclide activity may be underestimated because gross activity was not assigned to a specific radionuclide or because a radionuclide was present, but not characterized and reported. Gross activity or mixed fission product activity not assigned to a specific radionuclide was converted to the activity of specific radionuclides by assuming that it had the same radionuclide composition as the NTS underground testing inventory. Most gross activity was disposed prior to 1978 when the NTS testing programs were the predominant waste source. Specific corrections were applied for radionuclides believed to be systematically underreported by generator waste characterization. Corrections were performed for fission products and transuranic radionuclides in uranium, uranium isotopes in depleted and enriched uranium, and transuranic radionuclides in scrap plutonium. The uncertainty in the corrections was estimated and propagated by Monte Carlo simulation through the summation of the total inventory.

The results of data base queries may be biased relative to the activity reported by the generator. This may occur through data entry errors, incomplete data entry into the data base, and structural problems known to exist in the data base that make complete retrieval of data difficult. These problems may cause both overestimation and underestimation of the inventory. Data entry errors in the data base were reduced in 1996 when data base entries were verified against original shipping records. As an additional check, the largest-activity shipments were reviewed and verified against shipping records during preparation of this inventory. The incompleteness of the data base queries was assessed by comparing the physical volume of the disposal units with the waste volume recorded in the data base. The data base waste volume was 67 to 110 percent of the physical volume of the trenches. The activity in the potentially missing volume was estimated assuming an average radionuclide concentration and the missing activity was added to the inventory.

The shallow pits and trenches inventory analyzed in the CA is the sum of the pre-1988 inventory developed in Appendix 1 and the post-1988 inventory estimated in the Area 5 RWMS PA (see Table A1.11). At closure, the inventory is predominantly ${ }^{3} \mathrm{H},{ }^{137} \mathrm{Cs}$, and ${ }^{90} \mathrm{Sr}$ on an activity basis. After a few hundred years, the inventory is predominantly ${ }^{238} \mathrm{U},{ }^{234} \mathrm{U},{ }^{239} \mathrm{Pu}$, and ${ }^{99} \mathrm{Tc}$.

An inventory for the GCD boreholes has previously been reported (Chu and Bernard, 1991). This inventory was adopted with minor corrections for fission products and transuranic radionuclides in uranium, uranium isotopes in depleted and enriched uranium, and transuranic radionuclides in scrap plutonium. On an activity basis, the GCD inventory is predominantly ${ }^{3} \mathrm{H}$, ${ }^{90} \mathrm{Sr}$, and ${ }^{137} \mathrm{Cs}$ disposed in the GCDT (Table 4.1). The inventory of long-lived radionuclides is dominated by ${ }^{239} \mathrm{Pu},{ }^{240} \mathrm{Pu}$, and ${ }^{241} \mathrm{Am}$. 
Table 4.1 Estimated Inventory for the Area 5 RWMS GCD and GCDT Boreholes. Activities are reported for late 1991. The data are estimated from Chu and Bernard (1991) and Cochran (personal communication, 1997)

\begin{tabular}{cccc}
\hline Nuclide & $\begin{array}{c}\text { Total } \\
\text { (Ci) }\end{array}$ & Nuclide & Total \\
\hline${ }^{3} \mathrm{H}$ & $2.8 \mathrm{e} 6$ & ${ }^{236} \mathrm{U}$ & $1.2 \mathrm{e}-2$ \\
${ }^{60} \mathrm{Co}$ & $3.3 \mathrm{e} 3$ & ${ }^{238} \mathrm{U}$ & $2.5 \mathrm{e} 0$ \\
${ }^{90} \mathrm{Sr}$ & ${ }^{237} \mathrm{~Np}$ & $5.9 \mathrm{e}-3$ \\
${ }^{99} \mathrm{Tc}$ & ${ }^{238} \mathrm{Pu}$ & $6.3 \mathrm{e} 0$ \\
${ }^{137} \mathrm{Cs}$ & $4.2 \mathrm{e} 5$ & ${ }^{239} \mathrm{Pu}$ & $3.2 \mathrm{e} 2$ \\
${ }^{226} \mathrm{Ra}$ & $2.0 \mathrm{e}-1$ & ${ }^{240} \mathrm{Pu}$ & $3.1 \mathrm{e} 1$ \\
${ }^{227} \mathrm{Ac}$ & $1.9 \mathrm{e} 4$ & ${ }^{241} \mathrm{Pu}$ & $6.3 \mathrm{e} 2$ \\
${ }^{232} \mathrm{Th}$ & $9.9 \mathrm{e} 1$ & ${ }^{242} \mathrm{Pu}$ & $6.3 \mathrm{e}-3$ \\
${ }^{234} \mathrm{U}$ & $8.0 \mathrm{e} 0$ & ${ }^{241} \mathrm{Am}$ & $7.6 \mathrm{e} 1$ \\
${ }^{235} \mathrm{U}$ & $2.0 \mathrm{e}-2$ & Total & $3.2 \mathrm{e} 6$ \\
\hline
\end{tabular}

\subsubsection{Screening Analysis for the Release of Nonvolatile Radionuclides from the Area 5 RWMS Shallow Pits and Trenches}

Simple conservative screening calculations were performed to determine which nonvolatile radionuclides released from the Area 5 RWMS shallow pits and trenches were most likely to contribute to the dose. The screening was performed by assuming that a resident was exposed to diluted waste at 250 and 1,000 years after closure. The waste was assumed to be diluted into a 2.4-m- (8-ft-)-thick soil cover. This is the maximum concentration that can occur assuming upward transport and that the cap concentration is not likely to ever exceed the waste concentration. Radionuclides causing a TEDE greater than $0.01 \mathrm{mrem} / \mathrm{yr}(0.03$ percent of the dose constraint) are retained for the $\mathrm{CA}$ (Table 4.2). The nuclides meeting the screening criteria are ${ }^{14} \mathrm{C},{ }^{36} \mathrm{Cl},{ }^{40} \mathrm{~K},{ }^{90} \mathrm{Sr}+\mathrm{D},{ }^{94} \mathrm{Nb},{ }^{99} \mathrm{Tc},{ }^{126} \mathrm{Sn}+\mathrm{D},{ }^{137} \mathrm{Cs}+\mathrm{D},{ }^{240} \mathrm{Pu},{ }^{236} \mathrm{U},{ }^{232} \mathrm{Th},{ }^{228} \mathrm{Ra}+\mathrm{D},{ }^{228} \mathrm{Th}+\mathrm{D},{ }^{239} \mathrm{Pu}$, ${ }^{235} \mathrm{U}+\mathrm{D},{ }^{231} \mathrm{~Pa},{ }^{227} \mathrm{Ac}+\mathrm{D},{ }^{238} \mathrm{Pu},{ }^{238} \mathrm{U}+\mathrm{D},{ }^{234} \mathrm{U},{ }^{230} \mathrm{Th},{ }^{226} \mathrm{Ra}+\mathrm{D},{ }^{210} \mathrm{~Pb}+\mathrm{D},{ }^{241} \mathrm{Pu},{ }^{241} \mathrm{Am},{ }^{237} \mathrm{~Np}+\mathrm{D},{ }^{233} \mathrm{U}$, and ${ }^{229} \mathrm{Th}+\mathrm{D}$. The " $+\mathrm{D} "$ notation indicates that progeny with half-lives less than one year are assumed to be in equilibrium. Nonvolatile radionuclides meeting the screening criterion were retained for the $\mathrm{CA}$ analysis. All volatile radionuclides were retained for analysis.

\subsection{Estimated Inventory of Contaminated Soil Corrective Action Units}

Several radiological site characterization projects have described contaminated soil sites on the NTS. Contaminated soil CAUs in Frenchman Flat and Plutonium Valley were selected for initial analysis. Eight CAUs having residual radioactive contamination were identified: the Frenchman Flat playa soil site (CAU 106), the 306 soil site (CAU 999, CAS 05-45-07), the 307 soil site (CAU 999, 05-45-05), the PIN STRIPE soil site (CAU 98, CAS 11-57-001), the Kay Block House (CAU 204, CAS 05-33-01), the Gravel Gertie (CAU 140, CAS 05-08-02), the GMX soil 
Table 4.2 Estimated Inventory of Shallow Pits and Trenches at the Area 5 RWMS at Closure in 2028 for Radionuclides Meeting the Screening Criteria. The ${ }^{3} \mathrm{H}$ inventory includes the GCD borehole inventory because of its potential mobility. The pre-1988 inventory is estimated in Appendix 1. The post-1988 inventory is from the Area 5 RWMS PA (Shott et al., 1997a).

\begin{tabular}{|c|c|c|c|c|c|c|}
\hline Nuclide & $\begin{array}{c}\text { Pre-1988 } \\
\text { Inventory at } \\
1988(\mathrm{Ci})\end{array}$ & $\begin{array}{l}\text { Standard } \\
\text { Deviation }\end{array}$ & $\begin{array}{c}\text { Post-1988 } \\
\text { Inventory at } \\
2028(\mathrm{Ci})\end{array}$ & $\begin{array}{l}\text { Standard } \\
\text { Deviation }\end{array}$ & $\begin{array}{c}\text { Total } \\
\text { Inventory at } \\
2028 \text { (Ci) }\end{array}$ & $\begin{array}{l}\text { Standard } \\
\text { Deviation }\end{array}$ \\
\hline${ }^{3} \mathrm{H}$ & $7.6 e+06$ & $8.6 e+05$ & $8.4 e+05$ & $2.1 \mathrm{e}+06$ & $1.6 \mathrm{e}+06$ & $2.1 \mathrm{e}+06$ \\
\hline${ }^{14} \mathrm{C}$ & $3.2 \mathrm{e}+00$ & $4.5 e+00$ & $1.1 \mathrm{e}+01$ & $2.7 \mathrm{e}+01$ & $1.4 \mathrm{e}+01$ & $2.4 \mathrm{e}+01$ \\
\hline${ }^{36} \mathrm{Cl}$ & $7.8 \mathrm{e}-01$ & $1.1 \mathrm{e}+00$ & $4.1 \mathrm{e}-07$ & $1.0 \mathrm{e}-06$ & $7.7 \mathrm{e}-01$ & $1.2 \mathrm{e}+00$ \\
\hline${ }^{39} \mathrm{Ar}$ & $4.4 \mathrm{e}+00$ & $5.2 \mathrm{e}+00$ & $0.0 \mathrm{e}+00$ & $0.0 \mathrm{e}+00$ & $3.8 \mathrm{e}+00$ & $4.6 \mathrm{e}+00$ \\
\hline${ }^{40} \mathrm{~K}$ & $1.1 \mathrm{e}+00$ & $1.3 \mathrm{e}+00$ & $0.0 \mathrm{e}+00$ & $0.0 \mathrm{e}+00$ & $1.1 \mathrm{e}+00$ & $1.3 \mathrm{e}+00$ \\
\hline${ }^{85} \mathrm{Kr}$ & $6.5 e+02$ & $6.7 \mathrm{e}+02$ & $7.0 \mathrm{e}-02$ & $1.7 \mathrm{e}-01$ & $4.6 e+01$ & $4.7 \mathrm{e}+01$ \\
\hline${ }^{90} \mathrm{Sr}$ & $2.3 \mathrm{e}+05$ & $2.6 \mathrm{e}+05$ & $1.3 \mathrm{e}+01$ & $3.2 \mathrm{e}+01$ & $9.0 \mathrm{e}+04$ & $9.8 \mathrm{e}+04$ \\
\hline${ }^{94} \mathrm{Nb}$ & $6.7 \mathrm{e}-01$ & $1.0 \mathrm{e}+00$ & $0.0 \mathrm{e}+00$ & $0.0 \mathrm{e}+00$ & $6.5 \mathrm{e}-01$ & $9.9 \mathrm{e}-01$ \\
\hline${ }^{99} \mathrm{Tc}$ & $4.1 \mathrm{e}+02$ & $6.2 \mathrm{e}+02$ & $7.7 \mathrm{e}+01$ & $1.9 \mathrm{e}+02$ & $4.9 \mathrm{e}+02$ & $6.3 e+02$ \\
\hline${ }^{126} \mathrm{Sn}$ & $2.5 \mathrm{e}-01$ & $2.9 \mathrm{e}-01$ & $3.4 \mathrm{e}-05$ & $8.4 \mathrm{e}-05$ & $2.4 \mathrm{e}-01$ & $2.9 \mathrm{e}-01$ \\
\hline${ }^{137} \mathrm{Cs}$ & $3.6 \mathrm{e}+05$ & $1.4 \mathrm{e}+05$ & $1.3 \mathrm{e}+01$ & $3.3 \mathrm{e}+01$ & $1.4 e+05$ & $1.4 \mathrm{e}+05$ \\
\hline${ }^{210} \mathrm{~Pb}$ & $5.3 \mathrm{e}-06$ & $5.9 \mathrm{e}-06$ & $9.7 \mathrm{e}-02$ & $2.4 \mathrm{e}-01$ & $3.2 \mathrm{e}+01$ & $7.0 \mathrm{e}+01$ \\
\hline${ }^{226} \mathrm{Ra}$ & $4.5 \mathrm{e}+01$ & $5.2 \mathrm{e}+01$ & $2.4 \mathrm{e}-01$ & $5.9 \mathrm{e}-01$ & $4.5 \mathrm{e}+01$ & $1.0 \mathrm{e}+02$ \\
\hline${ }^{228} \mathrm{Ra}$ & $0.0 \mathrm{e}+00$ & $0.0 \mathrm{e}+00$ & $0.0 \mathrm{e}+00$ & $0.0 \mathrm{e}+00$ & $2.2 \mathrm{e}+00$ & $8.4 \mathrm{e}+00$ \\
\hline${ }^{227} \mathrm{Ac}$ & $7.0 \mathrm{e}-01$ & $6.0 \mathrm{e}-01$ & $2.8 \mathrm{e}-01$ & $6.9 \mathrm{e}-01$ & $5.7 \mathrm{e}-01$ & $8.6 \mathrm{e}-01$ \\
\hline${ }^{228} \mathrm{Th}$ & $4.5 \mathrm{e}-02$ & $4.1 \mathrm{e}-02$ & $3.8 \mathrm{e}+00$ & $9.2 \mathrm{e}+00$ & $5.1 \mathrm{e}+00$ & $8.9 \mathrm{e}+00$ \\
\hline${ }^{229} \mathrm{Th}$ & $2.5 \mathrm{e}-09$ & $2.9 \mathrm{e}-09$ & $6.1 \mathrm{e}-06$ & $1.5 \mathrm{e}-05$ & $4.5 \mathrm{e}-03$ & $1.0 \mathrm{e}-02$ \\
\hline${ }^{230} \mathrm{Th}$ & $2.0 \mathrm{e}-01$ & $1.7 \mathrm{e}-01$ & $1.6 \mathrm{e}+00$ & $3.9 \mathrm{e}+00$ & $2.3 e+00$ & $5.2 \mathrm{e}+00$ \\
\hline${ }^{232} \mathrm{Th}$ & $1.9 \mathrm{e}+00$ & $1.7 \mathrm{e}+00$ & $5.0 \mathrm{e}+00$ & $1.2 \mathrm{e}+01$ & $7.0 \mathrm{e}+00$ & $1.2 \mathrm{e}+01$ \\
\hline${ }^{231} \mathrm{~Pa}$ & $9.9 \mathrm{e}-02$ & $1.2 \mathrm{e}-01$ & $1.6 \mathrm{e}-01$ & $4.0 \mathrm{e}-01$ & $3.4 \mathrm{e}-01$ & $6.2 \mathrm{e}-01$ \\
\hline${ }^{233} \mathrm{U}$ & $1.2 \mathrm{e}+00$ & $9.8 \mathrm{e}-01$ & $3.4 \mathrm{e}-03$ & $8.3 e-03$ & $1.2 \mathrm{e}+00$ & $9.7 \mathrm{e}-01$ \\
\hline${ }^{234} \mathrm{U}$ & $1.3 e+03$ & $9.0 \mathrm{e}+02$ & $1.4 \mathrm{e}+03$ & $3.5 \mathrm{e}+03$ & $2.7 e+03$ & $3.6 \mathrm{e}+03$ \\
\hline${ }^{235} \mathrm{U}$ & $9.1 \mathrm{e}+01$ & $6.1 \mathrm{e}+01$ & $8.0 \mathrm{e}+01$ & $2.0 \mathrm{e}+02$ & $1.7 \mathrm{e}+02$ & $2.0 \mathrm{e}+02$ \\
\hline${ }^{236} \mathrm{U}$ & $5.9 \mathrm{e}+01$ & $6.9 \mathrm{e}+01$ & $2.3 e+00$ & $5.6 \mathrm{e}+00$ & $6.1 \mathrm{e}+01$ & $6.9 \mathrm{e}+01$ \\
\hline${ }^{238} \mathrm{U}$ & $3.1 \mathrm{e}+03$ & $2.0 \mathrm{e}+03$ & $2.7 \mathrm{e}+03$ & $6.6 \mathrm{e}+03$ & $5.7 \mathrm{e}+03$ & $6.9 e+03$ \\
\hline${ }^{237} \mathrm{~Np}$ & $6.4 \mathrm{e}+00$ & $4.0 \mathrm{e}+00$ & $2.1 \mathrm{e}-02$ & $5.1 \mathrm{e}-02$ & $6.3 e+00$ & $4.0 \mathrm{e}+00$ \\
\hline${ }^{238} \mathrm{Pu}$ & $2.8 \mathrm{e}+02$ & $2.7 \mathrm{e}+02$ & $3.4 \mathrm{e}+02$ & $8.2 \mathrm{e}+02$ & $5.3 e+02$ & $8.4 \mathrm{e}+02$ \\
\hline${ }^{239} \mathrm{Pu}$ & $3.2 \mathrm{e}+02$ & $2.5 \mathrm{e}+02$ & $3.1 \mathrm{e}+02$ & $7.7 \mathrm{e}+02$ & $6.3 e+02$ & $6.9 \mathrm{e}+02$ \\
\hline${ }^{240} \mathrm{Pu}$ & $9.3 e+01$ & $6.5 \mathrm{e}+01$ & $6.5 \mathrm{e}+01$ & $1.6 \mathrm{e}+02$ & $1.6 \mathrm{e}+02$ & $1.4 \mathrm{e}+02$ \\
\hline${ }^{24 !} \mathrm{Pu}$ & $1.2 \mathrm{e}+02$ & $8.5 \mathrm{e}+02$ & $3.4 e+02$ & $8.2 \mathrm{e}+02$ & $5.0 e+02$ & $8.0 \mathrm{e}+02$ \\
\hline${ }^{241} \mathrm{Am}$ & $9.0 \mathrm{e}+01$ & $6.4 \mathrm{e}+01$ & $5.0 \mathrm{e}+01$ & $1.2 \mathrm{e}+02$ & $1.7 \mathrm{e}+02$ & $7.4 \mathrm{e}+03$ \\
\hline
\end{tabular}

site (CAU 365) in Frenchman Flat, and the Plutonium Valley soil site (CAU 366) in Plutonium Valley. Among these sites, the 306 soil site, the 307 soil site, the Kay Block House, and the Gravel Gertie were excluded from the CA because of their small inventories, small area, and 
distance from the Area 5 RWMS relative to sources süch as the GMX soil site and Frenchman Flat playa soil site. Additional discussion of these sites and the justification for their exclusion is provided in Appendix 1.

The inventories and areas of the remaining four sources are listed in Table 4.3. The CAU inventories and areas were estimated by the RIDP (McArthur, 1991) and the NAEG (Gilbert, 1977). The most significant sources are expected to be the GMX soil site and the Frenchman Flat playa soil site because of their proximity to the Area 5 RWMS and large area. The Plutonium Valley soil site is a potentially significant emission source, but is separated from the Area 5 RWMS by French Peak.

Table 4.3 Inventories in Curies and Area in Square Meters Estimated by the RIDP and NAEG for Important Contaminated Soil Corrective Action Units in Areas 5 and 11 as of 1990 (from McArthur, 1991; Gilbert, 1977)

\begin{tabular}{rlrrrrrrrrrrrr}
\hline Area & Region & Area & ${ }^{241} \mathbf{A m}$ & ${ }^{238} \mathbf{P u}$ & ${ }^{239} \mathbf{P u}$ & ${ }^{240} \mathbf{P u}$ & ${ }^{60} \mathbf{C o}$ & ${ }^{137} \mathbf{C s}$ & ${ }^{90} \mathbf{S r}$ & ${ }^{152} \mathbf{E u}$ & ${ }^{154} \mathbf{E u}$ \\
\hline \multirow{2}{*}{5} & Frenchman & & & & & & & & & & & & \\
& Playa & $5.7 \mathrm{e}+06$ & 0.4 & 0.1 & 2.6 & 0.8 & 1 & 0.4 & 1.1 & 12.1 & 0.8 \\
& GMX & $1.8 \mathrm{e}+06$ & 0.2 & 0 & 1.1 & 0.3 & 0 & 0 & 0 & 0.2 & 0 \\
\hline \multirow{2}{*}{11} & Plutonium & & & & & & & & & & & & \\
& Valley & $8.7 \mathrm{e}+06$ & 3.3 & 0.5 & 28 & 8.3 & 0 & 0.4 & 0.2 & 0 & 0 \\
& PIN STRIPE & $1.5 \mathrm{e}+06$ & 0 & 0 & 0 & 0 & 0 & 0.2 & 0.2 & 0 & 0 \\
\hline
\end{tabular}

\subsubsection{Screening Analyses of Radionuclide Emissions From Contaminated Soil Corrective Action Units}

The CAU inventories in Table 4.3 contain relatively small inventories of short-lived fission products and activation products. The short-lived fission and activation products $\left({ }^{60} \mathrm{Co}\left[\mathrm{t}_{1 / 2}=5.3\right.\right.$ years], ${ }^{90} \mathrm{Sr}\left[\mathrm{t}_{1 / 2}=28\right.$ years], ${ }^{177} \mathrm{Cs}\left[\mathrm{t}_{1 / 2}=30\right.$ years], ${ }^{152} \mathrm{Eu}\left[\mathrm{t}_{1 / 2}=14\right.$ years], and ${ }^{154} \mathrm{Eu}\left[\mathrm{t}_{1 / 2}=8.8\right.$ years $\left.]\right)$ will decay to negligible levels during the 250-year institutional control assumed for the NTS. Therefore, these nuclides are excluded from the inventory. This eliminates the PIN STRIPE soil site from the analysis because it includes only short-lived fission products and activation products.

The Plutonium Valley soil site, $13 \mathrm{~km}(8 \mathrm{mi})$ north of the Area 5 RWMS in Plutonium Valley, is a potentially large emission source for airborne plutonium. However, the mountain range lying between the Area 5 RWMS and the Plutonium Valley soil site is expected to block atmospheric dispersion. The downwind vertical dispersion of a gas or particulate released at ground level will be restricted by the ground surface and the overlying, more stable air mass that resists mixing. More stable air masses are typically found from 500 to $2,000 \mathrm{~m}(1,600$ to $6,500 \mathrm{ft})$ above the ground surface (EPA, 1979). Mountain ridges between the Plutonium Valley soil site and the 
Area 5 RWMS rise 120 to $330 \mathrm{~m}$ (400 to $1,100 \mathrm{ft}$ ) above the Plutonium Valley soil site within 2 to $5 \mathrm{~km}(1.2$ to $3 \mathrm{mi})$ of the source. Some portion of the plutonium particulate plume dispersing southward toward the Area 5 RWMS will encounter the rising ground surface and be blocked. The concentration of airborne plutonium at the Area 5 RWMS from the Plutonium Valley soil site was estimated with the Industrial Source Code, Long-Term (ISCLT), an atmospheric dispersion model, assuming that the mountain ranges were not present. The estimated concentrations were significantly higher than observed by the environmental monitoring program at the Area 5 RWMS. This supports the hypothesis that the intervening mountains significantly block atmospheric emissions. Results consistent with environmental monitoring data were obtained by including the Frenchman Flat sources and excluding the Plutonium Valley source. Therefore, the Plutonium Valley soil site was excluded from the CA analysis based on the assumption that the intervening mountain ranges are an effective barrier to atmospheric dispersion.

The two largest Frenchman Flat soil site CAUs, in terms of inventory and area, are retained for the CA. These are the GMX soil site and the Frenchman Flat playa soil site. If these CAUs are found to be insignificant, this will validate the elimination of the other smaller Frenchman Flat CAUs. 


\subsection{PERFORMANCE ANALYSIS}

This chapter describes the methods used to estimate the transfer of radionuclides from the screened sources to the resident and the TEDE received by the resident.

\subsection{Method Overview}

Chapter 4 identified four potential radionuclide sources in Frenchman Flat. Two sources, the GMX soil site and the Frenchman Flat playa soil site, are contaminated soil CAUs. They already exist in the accessible environment and are assumed to change little over the next 1,000 years. Two source terms, the Area 5 RWMS and the Frenchman Flat UGTA, are currently not in the accessible environment, but are assumed to release radionuclides over time to the accessible environment. The Area 5 RWMS is assumed to release radionuclides to the overlying soil cover, creating another contaminated soil site in the future. Additionally, volatile radionuclides may be released directly to the atmosphere above the disposal site. Residents residing within any of these three contaminated soil sites may receive internal and external radiological doses. The three contaminated soil sites may also transfer nonvolatile and, in the case of the Area 5 RWMS, volatile radionuclides through the atmospheric pathway to surrounding uncontaminated lands. Residents in these areas may be exposed to airborne radioactivity resuspended from the contaminated soil sites and radioactivity deposited on the soil over the 1,000-year compliance period.

The Frenchman Flat UGTA may release radioactive material to the alluvial aquifer, which may slowly migrate away from the test zero points. Residents in Frenchman Flat may use the groundwater and be exposed to contamination from the UGTA source. A peer review of a preliminary evaluation of radionuclide migration from the Frenchman Flat UGTA has concluded that there is significant uncertainty in the source inventory, source release rates, hydrostratigraphy, groundwater flow direction and velocity, and transport parameters. Because of the large uncertainty, reasonable assurance of compliance with the CA dose constraint and dose limit cannot be provided at this time. Therefore, the dose from consumption and use of groundwater contaminated by UGTA sources will not be quantified in this revision of the CA.

The first step in estimating the doses to future residents is to estimate the release of radionuclides from the remaining sources. The release rates are then used to estimate the radionuclide concentration in air and soil within Frenchman Flat. The highest radionuclide concentrations are expected to occur in air and soil directly over the Area 5 RWMS, the Frenchman Flat playa soil site, and the GMX soil site. The concentration of radionuclides in air and soil will decrease with increasing distance from these source areas.

Once the concentration and distribution of radionuclides in air and soil is estimated, the TEDE to a member of public residing in Frenchman Flat can be estimated. The TEDE is calculated for an average adult exposed in a residential scenario. Residents are assumed to be present in Frenchman Flat at 250 years after closure. The mean TEDE is estimated as a function of time. Compliance is assessed at the time within the interval from 250 to 1,000 years after closure when the mean TEDE reaches its maximum value. 


\subsection{Source Term Conceptual Models}

This section describes the release of radioactive materials from the contaminated soil CAUs and the Area 5 RWMS.

\subsubsection{Contaminated Soil Corrective Action Unit Source Term Conceptual Model}

The GMX soil site and the Frenchman Flat playa soil site consist of nonvolatile radionuclides distributed on surface soils. Over time, the radionuclides will slowly infiltrate into the soil column and may be slowly buried, if the site is accumulating sediment. These processes would be expected to lower the potential dose over time and have been conservatively ignored. The inventory of radioactive material is assumed to change over time by radioactive decay only. The short-lived fission and activation products will decay to negligible levels during institutional control of the NTS and have been excluded from the inventory. The ingrowth of progeny from long-lived isotopes of plutonium and ${ }^{241} \mathrm{Am}$ is assumed to be negligible over 1,000 years, except for the ingrowth of ${ }^{241} \mathrm{Am}$ from ${ }^{241} \mathrm{Pu}$. The decay and ingrowth of ${ }^{241} \mathrm{Pu}$ and ${ }^{241} \mathrm{Am}$ is modeled explicitly to account for their changing inventories.

Contaminated soil particulates are assumed to be resuspended into the atmosphere by wind. The radionuclide emissions are assumed to be proportional to the inventory. The constant of proportionality is the resuspension rate, previously measured for contaminated soil sites on the NTS. The resuspension rate is assumed to be constant over time. This assumption will tend to overestimate emissions because resuspension rates have been observed to decrease over time at the NTS (Anspaugh et al., 1975).

\subsubsection{The Area 5 Radioactive Waste Management Site Source Conceptual Model}

The Area 5 RWMS inventory has been divided into three categories based on the depth of burial. In Chapter 4, inventories were presented or referenced for the shallow pits and trenches, the lower cell of P06U, and the GCD boreholes. Conceptual models of source terms are described for each inventory below. Screening analyses are described for the deep source terms.

\subsubsection{Shallow Pits and Trenches Source}

The shallow pits and trenches inventory used in the CA includes the entire inventory estimated to be disposed at the Area 5 RWMS from 1960 to closure in 2028. To reduce the number of modeling cases, the inventory of volatile radionuclides disposed in GCD boreholes, which is limited to ${ }^{3} \mathrm{H}$, was added to the shallow pits and trenches inventory. Inclusion of the GCD volatile radionuclide inventory is conservative because it reduces the depth of burial and shortens the travel distance to the atmosphere. The source is assumed to be in a single disposal unit with a homogeneous radionuclide concentration.

For modeling purposes, the shallow pits and trenches inventory is divided into volatile and nonvolatile radionuclides. Radionuclides considered to be exclusively volatile are ${ }^{39} \mathrm{Ar}$ and ${ }^{85} \mathrm{Kr}$. 
The release and transport of radon isotopes are not estimated based on DOE guidance that doses from radon need not be considered (DOE, 1996a). Tritium and ${ }^{14} \mathrm{C}$ are assumed to be present in volatile and nonvolatile forms. Because the partitioning of ${ }^{3} \mathrm{H}$ and ${ }^{14} \mathrm{C}$ between volatile and nonvolatile forms is unknown, it is conservatively assumed that the full inventory of ${ }^{3} \mathrm{H}$ and ${ }^{14} \mathrm{C}$ is available for release in both forms, essentially doubling the inventory of these radionuclides. The volatile forms of ${ }^{3} \mathrm{H}$ and ${ }^{14} \mathrm{C}$ are assumed to be tritiated water (HTO) and $\mathrm{CO}_{2}$, respectively. Assuming volatile ${ }^{3} \mathrm{H}$ is present as HTO is conservative because the dose from this form is significantly higher than from the elemental (HT) form. Carbon dioxide is the expected form of volatile ${ }^{14} \mathrm{C}$ given the dry oxic conditions at the site.

All other radionuclides are assumed to be present in nonvolatile forms. For dosimetry purposes, nonvolatile radionuclides are assumed to be in a form with the largest dose factor (DF) with some important exceptions. Strontium is assumed to be present in a class D form that clears from the lungs with a half-time of less than 10 days. Chlorine is assumed to be present as the chloride anion because this is the most common environmental form. Thorium and plutonium are assumed to be present in oxide forms based on information provided by generators.

The types of waste forms disposed at the Area 5 RWMS are known, but their quantitative proportions are poorly known. Common waste forms on a volume basis are believed to include soil, construction debris, and compactible trash. Because quantitative information concerning the waste is not available, simple conservative assumptions are made. The disposal unit is assumed to be filled with a single homogeneous waste form with conservative radionuclide release properties. All radionuclides are assumed to be immediately available for release. The release of radionuclides is assumed to be unaffected by waste form or waste containers. Nonvolatile radionuclides are assumed to be adsorbed onto a soil-like material.

All volatile radionuclides (except ${ }^{3} \mathrm{H}$ ) are assumed to be available for immediate release to the air-filled pore space. Volatile ${ }^{3} \mathrm{H}$ is assumed to be released to the air-filled pore space as HTO. The specific activity of water vapor in the air-filled waste pore space is assumed to be equivalent to the specific activity of waste pore water.

The waste disposal unit is assumed to be closed with a single-layer alluvium cap. The cap is assumed to be maintained for at least 100 years after closure. Maintenance activities are assumed to include removal of all deeply rooted plants and repair of subsidence. The waste form is assumed to be compactible and to undergo subsidence during and after loss of institutional control. Subsidence is assumed to cause cracks to form in the cap that create preferential pathways for the release of volatile radionuclides. Cap thickness is assumed to be sufficient so that the cap remains above grade after subsidence is complete. The cap is assumed to be at least 2 to $6 \mathrm{~m}(6$ to $20 \mathrm{ft})$ thick throughout the compliance period.

\subsubsection{Lower Cell of Pit 6 (P06U)}

Pit $6(\mathrm{P} 06 \mathrm{U})$ has been excavated to a depth of $14.6 \mathrm{~m}(48 \mathrm{ft})$ to provide greater isolation of thorium waste. A screening analysis was performed to demonstrate that the distance between the 


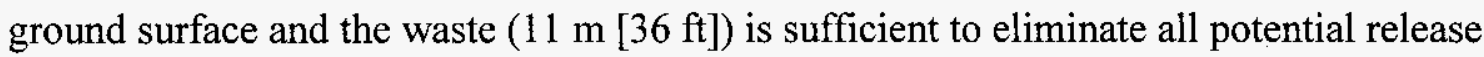
processes for nonvolatile radionuclides. A more complete explanation of the analysis can be found in Appendix 2. The waste source term may release nonvolatile radionuclides to the overlying soil cover by biointrusion or upward liquid advection. Review of the literature for arid desert sites indicates the plant rooting and animal burrowing below a depth of $10 \mathrm{~m}(33 \mathrm{ft})$ is unlikely. Thorium and its progeny may still dissolve in soil pore water and be advected upward toward the root zone and soil surface.

The upward advective water flux was estimated using a stable isotope approach and a soil physics approach. The stable isotope approach is based on estimates of upward flux prepared for the Area 5 RWMS (Chapman, 1995) and the Area 3 RWMS (Chapman, 1997). The flux estimate for the Area 5 RWMS was revised in 1998 to include the vapor flux (Chapman, 1998). The revised Area 5 RWMS flux estimate has a mean and standard deviation of $2.7 \mathrm{e}-4 \pm 1.4 \mathrm{e}-4$ $\mathrm{m} / \mathrm{yr}(1 \mathrm{e}-2 \pm 5 \mathrm{e}-3 \mathrm{inch}[\mathrm{in}] / \mathrm{yr})$, and a range from $1.1 \mathrm{e}-4$ to $5.5 \mathrm{e}-4 \mathrm{~m} / \mathrm{yr}(4 \mathrm{e}-3$ to $2 \mathrm{e}-2 \mathrm{in} / \mathrm{yr})$. Using this method, the maximum upward liquid velocity under current site conditions was estimated to be $3 \mathrm{e}-3 \mathrm{~m} / \mathrm{yr}(0.1 \mathrm{in} / \mathrm{yr})$ (Table 5.1).

Table 5.1 Estimated Upward Advection Flux and 1,000-Year Travel Length at the Area 5 Radioactive Waste Management Site Under Current Conditions.

\begin{tabular}{ccc}
\hline Statistic & Soil Physics Method & Stable Isotope Method \\
\hline Max. Upward Velocity $(\mathrm{m} / \mathrm{yr})$ & $2 \mathrm{e}-4$ & $3 \mathrm{e}-3$ \\
Max. 1,000 yr Travel Length $(\mathrm{m})$ & $1 \mathrm{e} 0$ & $3 \mathrm{e} 0$ \\
$\begin{array}{c}\text { Retarded } 1,000-\mathrm{yr} \text { Travel Length }(\mathrm{m}) \\
\left(\mathrm{U} \mathrm{Kd}=3.5 \mathrm{e}-2 \mathrm{~m}^{3} / \mathrm{kg}\right)\end{array}$ & $7 \mathrm{e}-4$ & $1 \mathrm{e}-2$ \\
\hline
\end{tabular}

The upward liquid velocity was also estimated using Darcy's law and hydrogeological site characterization data collected at the Area 5 RWMS. First, a paired soil moisture retention curve and saturated hydraulic conductivity were selected randomly from a set of 70 paired observations obtained at the Area 5 RWMS. The matric potential and its gradient were then sampled randomly from continuous distributions derived from site characterization data. Using this method, the maximum upward liquid velocity under current site conditions was estimated to be only $2 \mathrm{e}-4 \mathrm{~m} / \mathrm{yr}(9 \mathrm{e}-3 \mathrm{in} / \mathrm{yr})$.

The upward liquid flux derived from stable isotope data was used to bound the travel length of a dissolved solute in 1,000 years. The length traveled in 1,000 years by a nonadsorbing solute was estimated by dividing the flux by the water content and multiplying by time. The maximum length traveled in 1,000 years was estimated to be $3 \mathrm{~m}(10 \mathrm{ft})$. The travel length is calculated for a nonabsorbing solute. The most mobile element in the P06U inventory, uranium, has a retarded 1,000-year travel distance of $1 \mathrm{e}-2 \mathrm{~m}(0.4 \mathrm{in} / \mathrm{yr})$. 
The screening analysis demonstrates that there is no significant release mechanism for the P06U nonvolatile radionuclide source term over the next 1,000 years. Consequently, the release of radionuclides from the P06U source term is assumed to be zero. The P06U inventory is not expected to contain any volatile radionuclides except isotopes of radon, which are excluded from the CA by DOE guidance.

\subsubsection{Greater Confinement Disposal and Greater Confinement Disposal Test}

Waste disposed in GCD boreholes is covered by $21 \mathrm{~m}$ ( $69 \mathrm{ft}$ ) of soil. Based on the results of the screening analysis described in the previous section, the $21 \mathrm{~m}(69 \mathrm{ft})$ depth of burial is assumed to eliminate the potential for release of nonvolatile radionuclides from the GCD and GCDT. The GCD and GCDT inventory includes volatile radionuclides that may be released from the source term to the waste air-filled pore space. This inventory, consisting of ${ }^{3} \mathrm{H}$ only, has been added to the shallow pits and trenches inventory to reduce the number of required analyses.

\subsection{Conceptual Models of Transport}

In this section, the conceptual models are described for processes transporting radionuclides from each source to a resident. Conceptually, the transport process has been divided into two components. The first component, the transport conceptual model, addresses the transport from the source to one of two environmental media (air and soil) in the accessible environment. The transport of nonvolatile and volatile radionuclides is treated separately. The second component, the pathways conceptual model described in Section 5.4, addresses the pathways that allow exposure of residents to radionuclides in the accessible environment. The models are developed based on the site characterization data and information presented in the Area 5 RWMS PA.

\subsubsection{Transport Models for the Shallow Pits and Trenches at the Area 5 RWMS}

\subsubsection{Nonvolatile Radionuclides}

As described in the source conceptual model, nonvolatile radionuclides are assumed to be immediately available for transport. Processes expected to transport nonvolatile radionuclides from the source to the accessible environment are:

- Advection and diffusion of solutes in soil pore water;

- Uptake, translocation, and senescence of plants rooted in the waste and cap soil;

- Physical transport of waste by animals burrowing into the waste and cap soil; and

- Resuspension of cap soil.

The current climatic conditions, where potential evapotranspiration is 14 times higher than precipitation, are assumed to prevail in the future. Infiltrating precipitation is assumed to penetrate the alluvium only a few meters before it is returned to the atmosphere by evapotranspiration. Recharge of the uppermost aquifer, $240 \mathrm{~m}$ ( $790 \mathrm{ft}$ ) below the site, through the alluvial sediments is assumed to be negligible. The closure cap design is assumed to compensate 
for subsidence and eliminate the potential for ponding of run-on in the cap. Under these conditions, all precipitation infiltrating into the disposal unit returns to the atmosphere as evapotranspiration and no significant recharge occurs.

The long-term net advection of soil pore water and dissolved solutes is assumed to be upward through the waste and closure cap. However, in the very near surface, the soil moisture content is assumed to be so low that the advective flow of soil pore water ceases. Diffusion may spread the radionuclides dissolved in the pore water of the waste in any direction. However, lateral and downward transport due to diffusion is ignored because of the very low diffusion rates, and the contribution of diffusion is bounded by the conservative upward advective flux assumed.

Native plants, characteristic of the current desert shrub communities, are assumed to root in the closure cap after the 100-year maintenance period. Plant roots are assumed to be concentrated in

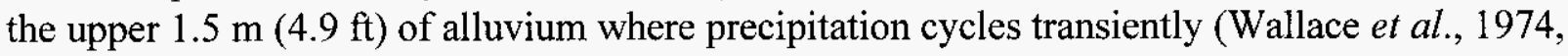

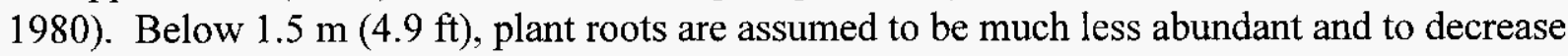
rapidly with depth. The mean maximum rooting depth is assumed to be $2.4 \mathrm{~m}(7.9 \mathrm{ft})$, with an

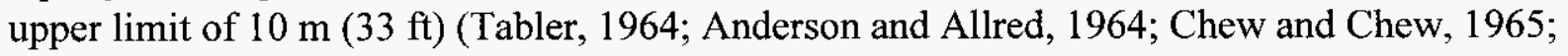
Barbour, 1973; Cline et al., 1980; Wallace et al., 1980, Klepper et al., 1985; Reynolds and Laundre, 1988; Link et al., 1994). Plant roots are assumed to absorb radionuclides from the waste and cap soil and to translocate those radionuclides throughout their underground and aboveground tissues. The plants are assumed to die and decay, returning the absorbed radionuclides to the cap soil. The mass of plant tissue returned annually to the soil is assumed to equal annual aboveground and underground primary productivity.

Vertebrates and invertebrates characteristic of the native fauna are assumed to construct burrows in the cap. All data indicate that vertebrates are unlikely to burrow deep enough to penetrate a 2-m (10-ft) cap (Anderson and Allred, 1964; McGrew, 1979; Cline et al., 1980; Winsor and Whicker, 1980; Reynolds and Wakkinen, 1987; Reynolds and Laundre, 1988; US Ecology, 1989). There is, however, a potential for invertebrates to reach depths beyond this depth. Therefore, the conceptual model assumes that invertebrates can burrow directly into the waste. Vertebrate burrowing is assumed to occur only in the upper $1.5 \mathrm{~m} \mathrm{(4.9} \mathrm{ft})$ of the cap and to cause a slow mixing of cap soil. The invertebrate burrowing depth is assumed to correspond with plant rooting depth. Invertebrate burrowing activity is assumed to be uniformly distributed with depth. Soil and waste excavated by invertebrates is mixed into overlying soil layers.

Radionuclides in surface soil are assumed to be lost from the cap by resuspension and dispersion off site. Radionuclides are assumed to undergo radioactive decay and ingrowth during all transport process.

The mathematical implementation of the nonvolatile radionuclide transport model is described in detail in Appendix 2. The model represents the system as a series of linked compartments. Transfer of radionuclides between compartments is represented by first-order rate constants accounting for liquid advection, plant uptake, and animal burrowing. Radionuclides undergo 
radioactive decay and ingrowth within the compartments. Parameter values and compartment dimensions are sampled from statistical distributions that represent uncertainty in the numerical values.

\subsubsection{Volatile Radionuclides}

Processes identified that could transport the volatile radionuclide source to the accessible environment are:

- Gaseous diffusion in the air-filled pore space,

- Gaseous advection in the air-filled pore space, and

- Plant root uptake and transpiration of HTO.

Gases released to the waste pore space are assumed to diffuse through the air-filled pore space of the cap to the atmosphere. Cracking caused by subsidence is assumed to create a preferential pathway where diffusion is not retarded by the tortuosity of the porous medium. Cracks are not present until the 100-year maintenance period ends. Moisture in soil pores is assumed to retard diffusion by blocking pathways through the porous medium. Plants are assumed to release ${ }^{3} \mathrm{H}$ to the atmosphere by transpiration. This release is assumed to be equal to the upward ${ }^{3} \mathrm{H}$ flux from the waste. The annual release of volatile radionuclides is assumed to be constrained by the total inventory present.

Advective transport of volatile radionuclides through the cap is assumed to be small. Past investigations of radon migration in earthen caps have found that pressure-driven advection is small compared to diffusion (Clements and Wilkening, 1974; Nazaroff, 1992). In addition, the atmospheric condition that drives advection, rapidly dropping atmospheric pressure, occurs only during a small fraction of the time in a typical year. Therefore, advection was assumed to be small relative to diffusion when integrated over an entire year and was not included in the conceptual model of volatile radionuclide transport. As noted, the volatile radionuclide release is constrained by the inventory. For all nuclides except ${ }^{3} \mathrm{H}$, the annual release estimated by the model is limited by the inventory. Therefore, the release of all nuclides except ${ }^{3} \mathrm{H}$ estimated by the model will be unaffected by the exclusion of advective transport.

The concentration of volatile radionuclides in air above the Area 5 RWMS is estimated assuming complete mixing into a 2-m (6.6-ft) compartment above the disposal site. Volatile radionuclides are advected and dispersed off site.

The mathematical implementation of the volatile radionuclide transport model is described in detail in Appendix 2. The model calculates the flux as the area weighted mean flux from the intact cap and cracks. The fluxes from each area are calculated as the product of an effective diffusion coefficient and the concentration gradient in the cap. The effective diffusion coefficient is the free-air diffusion coefficient corrected for the effects of tortuosity and soil water content. The concentration gradient is obtained as a steady-state solution to a one-dimensional mass balance expression that accounts for diffusion and radioactive decay in the cap. The flux is 
also calculated assuming complete release of the inventory in a year. The flux is the lesser of the two values. Parameter values are sampled from statistical distributions that represent uncertainty in the numerical values.

\subsubsection{Off-Site Dispersion of Volatile and Nonvolatile Radionuclides}

Nonvolatile radionuclides in surface soils at the Area 5 RWMS, the Frenchman Flat playa soil site, and the GMX soil site are assumed to be transferred to off-site locations by atmospheric dispersion of resuspended soil. The atmospheric dispersion is modeled with a Gaussian plume model assuming time-averaged atmospheric conditions. Volatile radionuclides released from the Area 5 RWMS are similarly assumed to be dispersed off site. Nonvolatile radionuclides dispersed off site are deposited on the ground surface by dry deposition.

The conceptual model of off-site atmospheric dispersion was implemented with the ISCLT model (EPA, 1995). The model uses a straight-line Gaussian dispersion model that assumes the plume is dispersed horizontally and vertically as it moves downwind. The dispersion coefficients are empirical functions of atmospheric conditions. Input atmospheric conditions are annual average frequencies of wind direction, wind speed, and atmospheric stability class. The atmospheric concentrations and deposition rates estimated are annual averages. The ISCLT model was run with the mean and 95th percentile radionuclide emission rates from the contaminated soil sites.

\subsection{Pathway Scenarios}

The pathways conceptual model is based on a reasonably probable and conservative exposure scenario. The exposure scenario is based on the elicitation of a panel of SMEs considering the probability of intrusion at the Areas 5 and 3 RWMSs. The SME's opinion was that the most probable exposure scenario for Frenchman Flat is a small rural community of commuters that work at a remote location. The scenario assumes that the resident works 40 hours per week at a site outside of Frenchman Flat. The resident's time is divided between time at work, time sleeping, time spent on sedentary indoor activities, time spent outdoors, and time spent producing agricultural products for personal use. The resident's agricultural activities include cultivation of a small noncommercial garden and noncommercial livestock production. Water for domestic and agricultural uses is assumed to come from the uppermost aquifer. The resident is assumed to live in Frenchman Flat when institutional control is lost at 250 years after closure.

Inclusion of agriculture in the pathway scenario will tend to yield conservative estimates of dose for this site. Noncommercial production of vegetables and livestock is an uncommon practice in southern Nevada because of the arid climate and infertile soils. Irrigation-based commercial agriculture is virtually nonexistent in southern Nevada at locations without shallow groundwater resources (Richard-Haggard, 1983; U.S. Department of Commerce [DOC], 1987). Parameters selected to calculate the dose from agricultural pathways are consistent with noncommercial 
activities and the limited contaminated areas available for agricultural use. Because the agricultural activities are noncommercial, it is assumed that residents will not initiate large-scale irrigation. Because some urban and rural residents of Nevada do produce vegetables for personal consumption (EPA, 1984), the resident is assumed to produce small quantities of leafy vegetables, root vegetables, and fruits on the site. Grains are not commonly grown for personal consumption in southern Nevada and are not included (DOC, 1987). Commercial and noncommercial livestock production does occur in southern Nevada (DOC, 1987). The resident is assumed to produce beef, milk, poultry, and eggs. Large-scale irrigation of a forage crop is assumed to be unreasonable for the location and scenario. Therefore, livestock are assumed to consume contaminated natural forage and uncontaminated feed produced at an off-site location.

In the pathway scenario, the resident is exposed to radioactivity in air and soil by:

- Inhalation of resuspended soil particulate,

- Inhalation of gaseous radionuclides,

- Immersion in gaseous radionuclides,

- External irradiation from radionuclides in soil,

- Inadvertent ingestion of soil,

- Ingestion of vegetables,

- Ingestion of beef and milk from range-fed cattle, and

- Ingestion of meat and eggs from range-fed poultry.

Although the resident may be exposed through water-dependent pathways, the TEDE from groundwater use is not estimated because of the substantial uncertainty in the UGTA contribution.

A complete description of the mathematical model and parameters used to calculate the doses for the community scenario with agriculture is provided in Appendix 3. The TEDE is calculated as the product of the radionuclide concentration in the accessible environment and a scenario dose conversion factor (SDCF) that gives the ratio between TEDE and environmental concentration. Scenario dose conversion factors are calculated for exposure to radionuclides in soils, nonvolatile radionuclides in air, and volatile radionuclides in air. 
This Page Intentionally Left Blank 


\subsection{RESULTS OF ANALYSES}

This chapter summarizes the results of the radiological assessments for the individual radionuclide sources in Frenchman Flat. Results are presented for the Area 5 RWMS, the Frenchman Flat playa soil site, the GMX soil site, and off-site areas not a part of any contaminated soil site. The uncertainty and sensitivity of the results are discussed.

\subsection{Results for the Area 5 Radioactive Waste Management Site}

The TEDE from volatile and nonvolatile radionuclides released from the Area 5 RWMS are presented separately. The results are for a resident living directly over the site.

\subsubsection{Nonvolatile Radionuclides}

The nonvolatile radionuclide release and transfer model estimates the upward release from waste to the overlying cap. The release is assumed to occur through plant uptake, animal burrowing, and upward liquid advection. Radionuclides are lost from the cap soil by radioactive decay and resuspension. The model was run for the list of screened radionuclides described in Chapter 4 .

After closure, surface soil concentrations estimated by the model rise as the release processes transfer radioactivity to the cap. Eventually, the concentrations reach a peak, and decrease because of radioactive decay and resuspension. Radionuclides with half-lives much less than 1,000 years, such as ${ }^{90} \mathrm{Sr}$ and ${ }^{137} \mathrm{Cs}$, reach their peak concentrations within the 1,000 -year compliance period (Figure 6.1). The long-lived radionuclides evaluated in the model reach their peak concentrations well beyond the 1,000-year compliance period.

Preliminary modeling cases, which assumed no cap maintenance, predicted that ${ }^{90} \mathrm{Sr}$ and ${ }^{137} \mathrm{Cs}$ would reach easily detectable peak concentrations at approximately 40 years after closure. These results were inconsistent with environmental monitoring data which show no detectable contamination for disposal units closed over 30 years ago. The preliminary model made several conservative assumptions that may explain the difference between the model result and field observation. The model ignores the ability of waste containers and waste forms to retard the release of radionuclides. The model also ignores that plants are routinely removed from the cap by waste operations. The final modeling cases for short-lived radionuclides assume that there is zero plant growth during a 100 -year period of cap maintenance. This reduces the peak concentration occurring during the first 100 years after closure.

Radionuclides with half-lives much longer than 1,000 years accumulate in cap soil throughout the compliance period (Figure 6.1). The peak concentrations for these nuclides will occur beyond 1,000 years. By 200 years, ${ }^{99} \mathrm{Tc},{ }^{238} \mathrm{U},{ }^{234} \mathrm{U},{ }^{36} \mathrm{Cl}$, and ${ }^{239} \mathrm{Pu}$ are expected to become the predominant radionuclides in cap soil on a concentration basis.

The mean TEDE for a resident at the Area 5 RWMS as a function of time was estimated from the mean surface soil concentrations (Figure 6.2). After the 250-year institutional control period, 
'SWMY

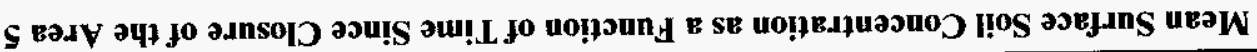

I·9 ว.มกริ!

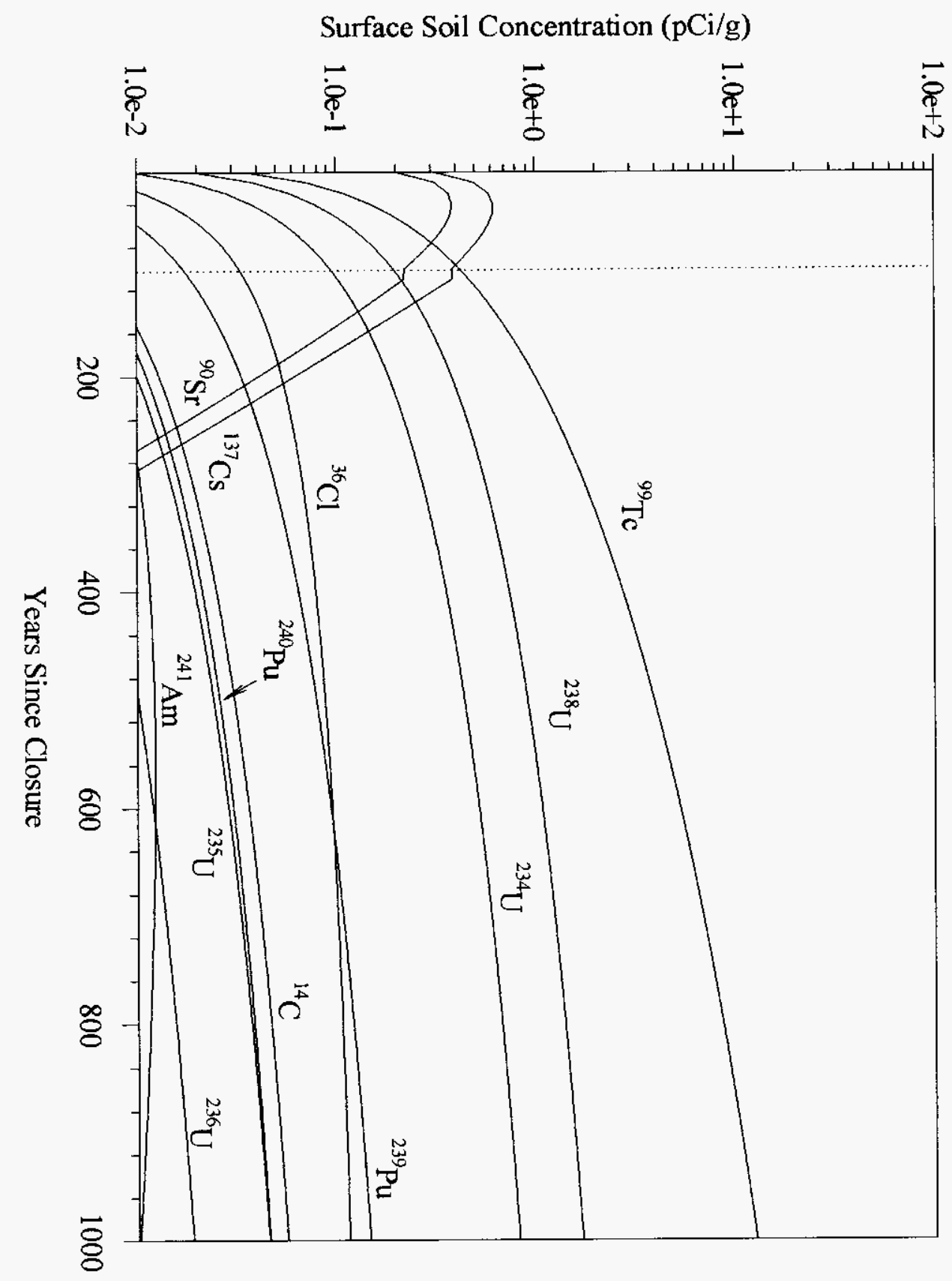




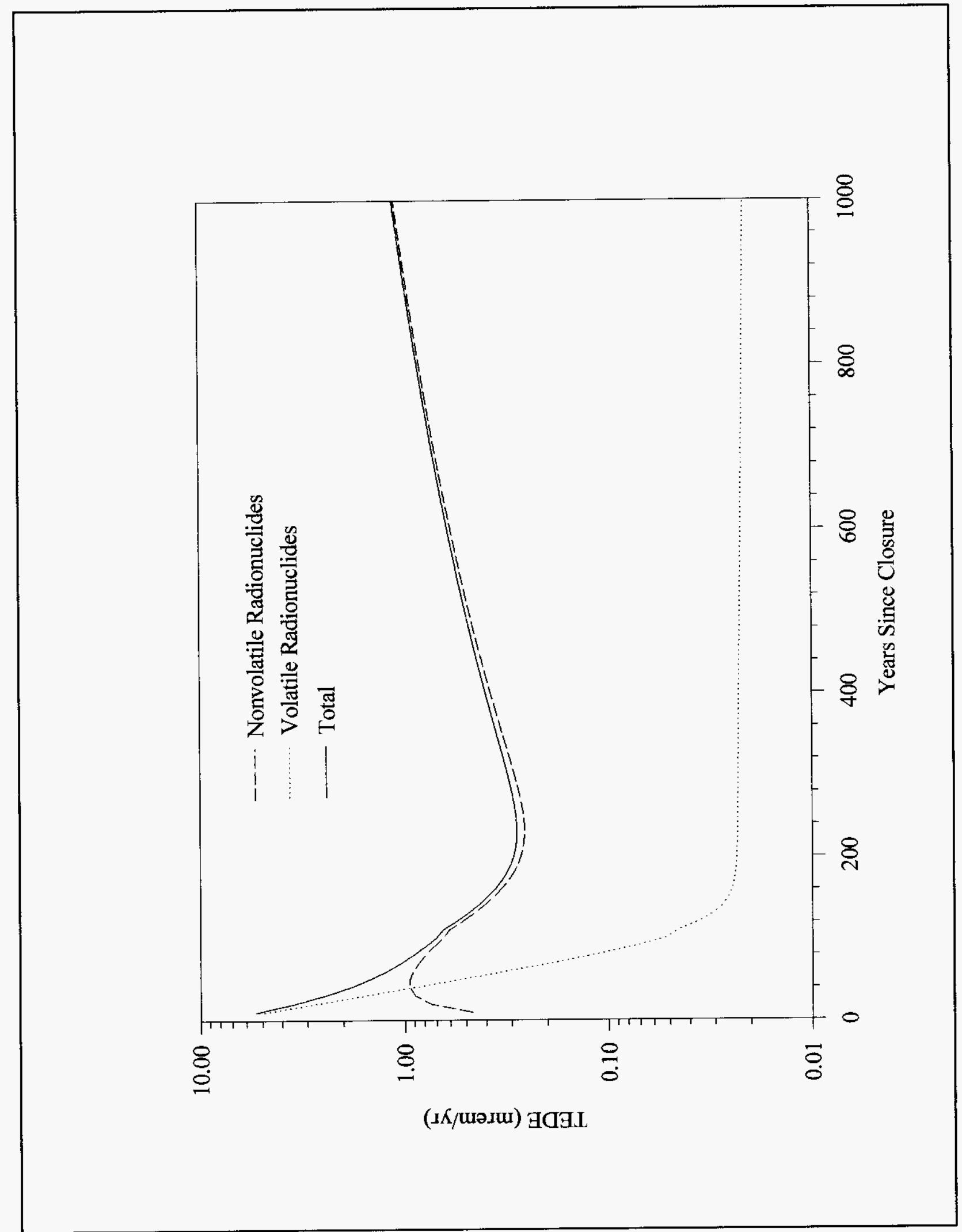

Figure 6.2

Estimated Mean TEDE to a Resident Living at the Area 5 RWMS from the Disposed Waste Inventory. 
the mean TEDE increases throughout the remaining 1,000-year compliance period as long-lived radionuclides accumulate in the surface soil. The mean annual TEDE reaches a maximum of $1 \mathrm{mrem}$ at 1,000 years (Table 6.1). Approximately 95 percent of the TEDE is contributed by ${ }^{99} \mathrm{Tc},{ }^{238} \mathrm{U},{ }^{36} \mathrm{Cl},{ }^{234} \mathrm{U},{ }^{226} \mathrm{Ra}$, and ${ }^{239} \mathrm{Pu}$. The most significant exposure pathway is ingestion of ${ }^{99} \mathrm{Tc}$ in vegetables and animal products.

Table 6.1 Mean and 95th Percentile TEDE for a Resident at the Area 5 RWMS

\begin{tabular}{cccccc}
\hline & \multicolumn{2}{c}{ 250 Years After Closure } & 1,000 Years After Closure \\
\cline { 2 - 5 } Source Term & $\begin{array}{c}\text { Mean } \\
(\mathbf{m r e m} / \mathbf{y r})\end{array}$ & $\begin{array}{c}\text { 95th Percentile } \\
\text { (mrem/yr) }\end{array}$ & $\begin{array}{c}\text { Mean } \\
\text { (mrem/yr) }\end{array}$ & $\begin{array}{c}\text { 95th Percentile } \\
\text { (mrem/yr) }\end{array}$ \\
\hline Nonvolatile & 0.3 & 1 & 1 & 4 \\
Volatile & 0.02 & 0.08 & 0.02 & 0.02 \\
Total & 0.3 & 1 & 1 & 4 \\
\hline
\end{tabular}

Nonvolatile radionuclides released to surface soil are also resuspended and transferred to off-site locations. The mean and 95th percentile emission rates of radionuclides to the atmosphere were estimated from the surface soil concentrations (Table 6.2). The radionuclides with the highest soil concentrations $\left({ }^{99} \mathrm{Tc},{ }^{238} \mathrm{U},{ }^{234} \mathrm{U},{ }^{36} \mathrm{Cl}\right.$, and $\left.{ }^{239} \mathrm{Pu}\right)$ have the highest emission rates. The radionuclide with the highest release rate $\left({ }^{99} \mathrm{Tc}\right)$ has an estimated annual mean emission of approximately $0.5 \mathrm{mCi} / \mathrm{yr}$ at 1,000 years.

\subsubsection{Volatile Radionuclides}

The release of volatile radionuclides to the atmosphere by diffusion through the cap was estimated using the volatile radionuclide release model. Volatile radionuclides are assumed to be immediately and completely released to the air-filled pores of the waste and to diffuse through the cap to the atmosphere. The annual emission cannot exceed the site inventory.

The mean TEDE from volatile radionuclides decreases throughout the compliance period as the volatile radionuclides undergo radioactive decay (Figure 6.2). Tritium contributes most of the mean TEDE for the first 100 years after closure. Afterwards, the TEDE becomes relatively constant as ${ }^{14} \mathrm{C}$ becomes the major contributor to dose. The ${ }^{14} \mathrm{C}$ released annually is equal to the site inventory and is, therefore, insensitive to the transport model, its assumptions, and parameter values. The mean TEDE reaches a maximum in the compliance period of $0.02 \mathrm{mrem}$ at 250 years.

The volatile radionuclide release model is likely to overestimate the near-term radionuclide release. The mean atmospheric ${ }^{3} \mathrm{H}$ concentration estimated by the model at closure $(2 \mathrm{e}-8 \mu \mathrm{Ci} / \mathrm{ml})$ is 1,400 times higher than the highest environmental monitoring result for the Area 5 RWMS in 
Table 6.2 Mean and 95th Percentile Nonvolatile Radionuclide Emissions Rates from the Area 5 RWMS at 1,000 Years After Closure

\begin{tabular}{llcccc}
\hline Nuclide & $\begin{array}{c}\text { Mean } \\
{\left[\mathbf{C i} /\left(\mathbf{m}^{2} \mathbf{s}\right)\right]}\end{array}$ & $\begin{array}{c}95 \text { th Percentile } \\
{\left[\mathbf{C i} /\left(\mathbf{m}^{2} \mathbf{s}\right)\right]}\end{array}$ & $\begin{array}{c}\text { Mean } \\
{\left[\mathbf{C i} /\left(\mathbf{m}^{2} \mathbf{s}\right)\right]}\end{array}$ & $\begin{array}{c}95 \text { th Percentile } \\
{\left[\mathbf{C i} /\left(\mathbf{m}^{2} \mathbf{s}\right)\right]}\end{array}$ \\
\hline${ }^{14} \mathrm{C}$ & $4.9 \mathrm{e}-19$ & $8.7 \mathrm{e}-19$ & ${ }^{230} \mathrm{Th}$ & $9.4 \mathrm{e}-20$ & $3.5 \mathrm{e}-19$ \\
${ }^{36} \mathrm{Cl}$ & $1.2 \mathrm{e}-18$ & $3.7 \mathrm{e}-18$ & ${ }^{232} \mathrm{Th}$ & $2.1 \mathrm{e}-20$ & $7.3 \mathrm{e}-20$ \\
${ }^{40} \mathrm{~K}$ & $3.3 \mathrm{e}-20$ & $6.7 \mathrm{e}-20$ & ${ }^{23} \mathrm{~Pa}$ & $1.2 \mathrm{e}-20$ & $4.4 \mathrm{e}-20$ \\
${ }^{90} \mathrm{Sr}$ & $9.4 \mathrm{e}-27$ & $2.2 \mathrm{e}-26$ & ${ }^{233} \mathrm{U}$ & $4.2 \mathrm{e}-20$ & $1.7 \mathrm{e}-19$ \\
${ }^{94} \mathrm{Nb}$ & $2.2 \mathrm{e}-21$ & $1.0 \mathrm{e}-20$ & ${ }^{234} \mathrm{U}$ & $1.0 \mathrm{e}-17$ & $3.5 \mathrm{e}-17$ \\
${ }^{99} \mathrm{Tc}$ & $1.2 \mathrm{e}-16$ & $4.0 \mathrm{e}-16$ & ${ }^{235} \mathrm{U}$ & $5.7 \mathrm{e}-19$ & $1.9 \mathrm{e}-18$ \\
${ }^{126} \mathrm{Sn}$ & $8.6 \mathrm{e}-22$ & $4.5 \mathrm{e}-21$ & ${ }^{236} \mathrm{U}$ & $2.2 \mathrm{e}-19$ & $8.8 \mathrm{e}-19$ \\
${ }^{137} \mathrm{Cs}$ & $1.9 \mathrm{e}-26$ & $4.5 \mathrm{e}-26$ & ${ }^{238} \mathrm{U}$ & $1.9 \mathrm{e}-17$ & $8.0 \mathrm{e}-17$ \\
${ }^{210} \mathrm{~Pb}$ & $1.4 \mathrm{e}-19$ & $5.9 \mathrm{e}-19$ & ${ }^{237} \mathrm{~Np}$ & $2.5 \mathrm{e}-20$ & $1.2 \mathrm{e}-19$ \\
${ }^{226} \mathrm{Ra}$ & $1.4 \mathrm{e}-19$ & $3.9 \mathrm{e}-19$ & ${ }^{238} \mathrm{Pu}$ & $6.4 \mathrm{e}-22$ & $3.0 \mathrm{e}-21$ \\
${ }^{228} \mathrm{Ra}$ & $2.1 \mathrm{e}-20$ & $7.3 \mathrm{e}-20$ & ${ }^{230} \mathrm{Pu}$ & $2.5 \mathrm{e}-18$ & $1.1 \mathrm{e}-17$ \\
${ }^{227} \mathrm{Ac}$ & $1.2 \mathrm{e}-20$ & $4.3 \mathrm{e}-20$ & ${ }^{240} \mathrm{Pu}$ & $5.0 \mathrm{e}-19$ & $2.2 \mathrm{e}-18$ \\
${ }^{228} \mathrm{Th}$ & $2.1 \mathrm{e}-20$ & $7.3 \mathrm{e}-20$ & ${ }^{241} \mathrm{Am}$ & $1.2 \mathrm{e}-19$ & $4.6 \mathrm{e}-19$ \\
${ }^{229} \mathrm{Th}$ & $2.4 \mathrm{e}-21$ & $1.1 \mathrm{e}-20$ & & & \\
\hline
\end{tabular}

1998 (DOE, 1999c). Much of the ${ }^{3} \mathrm{H}$ inventory is solidified, encapsulated, or adsorbed on the waste form and will be released over many years instead of the immediate release assumed by the model. The mean and 95th percentile emission of volatile radionuclides was also estimated for transport off site (Table 6.3). Carbon-14 and ${ }^{39} \mathrm{Ar}$ are the only volatile radionuclides with half-lives long enough to have appreciable releases beyond 250 years. The annual emission of ${ }^{3} \mathrm{H}$ is estimated to be $0.001 \mathrm{Ci} / \mathrm{yr}$ at 250 years. The annual emission of ${ }^{14} \mathrm{C}$ is approximately 12 $\mathrm{Ci} / \mathrm{yr}$ throughout the compliance period. This release represents the entire ${ }^{14} \mathrm{C}$ site inventory and could only occur in a single year, as the entire inventory would be depleted afterwards.

Table 6.3 Mean and 95th Percentile Volatile Radionuclide Emissions Rates from the Area 5 RWMS at 1,000 Years After Closure

\begin{tabular}{lll}
\hline Nuclide & Mean $\left[\mathbf{C i} /\left(\mathrm{m}^{2} \mathbf{s}\right)\right]$ & 95th Percentile $\left.\left[\mathbf{C i} / \mathbf{m}^{2} \mathbf{s}\right)\right]$ \\
\hline${ }^{14} \mathrm{C}$ & $2.8 \mathrm{e}-12$ & $1.0 \mathrm{e}-11$ \\
${ }^{39} \mathrm{Ar}$ & $7.1 \mathrm{e}-14$ & $2.0 \mathrm{e}-13$ \\
\hline
\end{tabular}




\subsubsection{Total Inventory}

The mean TEDE from the total inventory is less than the 30 mrem dose constraint throughout the 1,000-year compliance period. The mean TEDE declines rapidly during the institutional control period as ${ }^{3} \mathrm{H},{ }^{90} \mathrm{Sr}$, and ${ }^{137} \mathrm{Cs}$ decay (Figure 6.2). From 250 to 1,000 years after closure, the mean TEDE is dominated by the nonvolatile radionuclide inventory. After the institutional control period, the mean annual TEDE rises gradually from $0.3 \mathrm{mrem}$ at 250 years to 1 mrem at 1,000 years.

\subsubsection{Uncertainty and Sensitivity}

The TEDE received by a resident at the Area 5 RWMS is expected to be sensitive to assumptions regarding the future state of the site. The model indicates that there is a potential for higher doses in the near term if institutional control is lost before 250 years, the cap is not maintained, or radionuclides (particularly ${ }^{3} \mathrm{H}$ ) are released rapidly from waste. Although higher doses could occur under any combination of these circumstances, it appears likely that the TEDE would remain less than 30 mrem in a year (Figure 6.2).

Another important assumption is that the cap remains above grade after subsiding. If the flood control berm fails and the cap subsides below grade and captures run-on, infiltration into the disposal units may increase. In extreme cases, this has the potential to initiate transfer of contamination to the uppermost aquifer. Installation of an alluvium cap thick enough to remain above grade after subsidence should be sufficient to eliminate this potential problem.

The results are also expected to be sensitive to the future land use. Approximately 60 percent of the TEDE at 1,000 years is attributable to ${ }^{99} \mathrm{Tc}$ and ${ }^{36} \mathrm{Cl}$ ingested in vegetables and animal products. If the resident does not engage in agriculture, as is likely, the TEDE estimates would be reduced significantly. If alternative land uses occur, such as recreational or industrial uses, lower doses would be expected.

The dose is relatively insensitive to the time institutional control is lost, assuming that control is maintained for at least 100 years. Higher doses from HTO may be possible if institutional control is lost before 100 years. Retention of HTO by solid waste forms will probably maintain doses well below the levels estimated by the model. Current environmental monitoring results for atmospheric HTO are several orders of magnitude less than estimated by the volatile radionuclide release model.

The contribution of input parameter uncertainty to the uncertainty in nonvolatile radionuclide release model results at 1,000 years was estimated by propagating the parameter uncertainty through the model by Monte Carlo simulation (Figure 6.3). All important transport parameters were sampled randomly. The SDCFs were held constant at the mean value. The mean and 95th percentile TEDE are less than the 30 -mrem dose constraint, indicating there is a high likelihood 


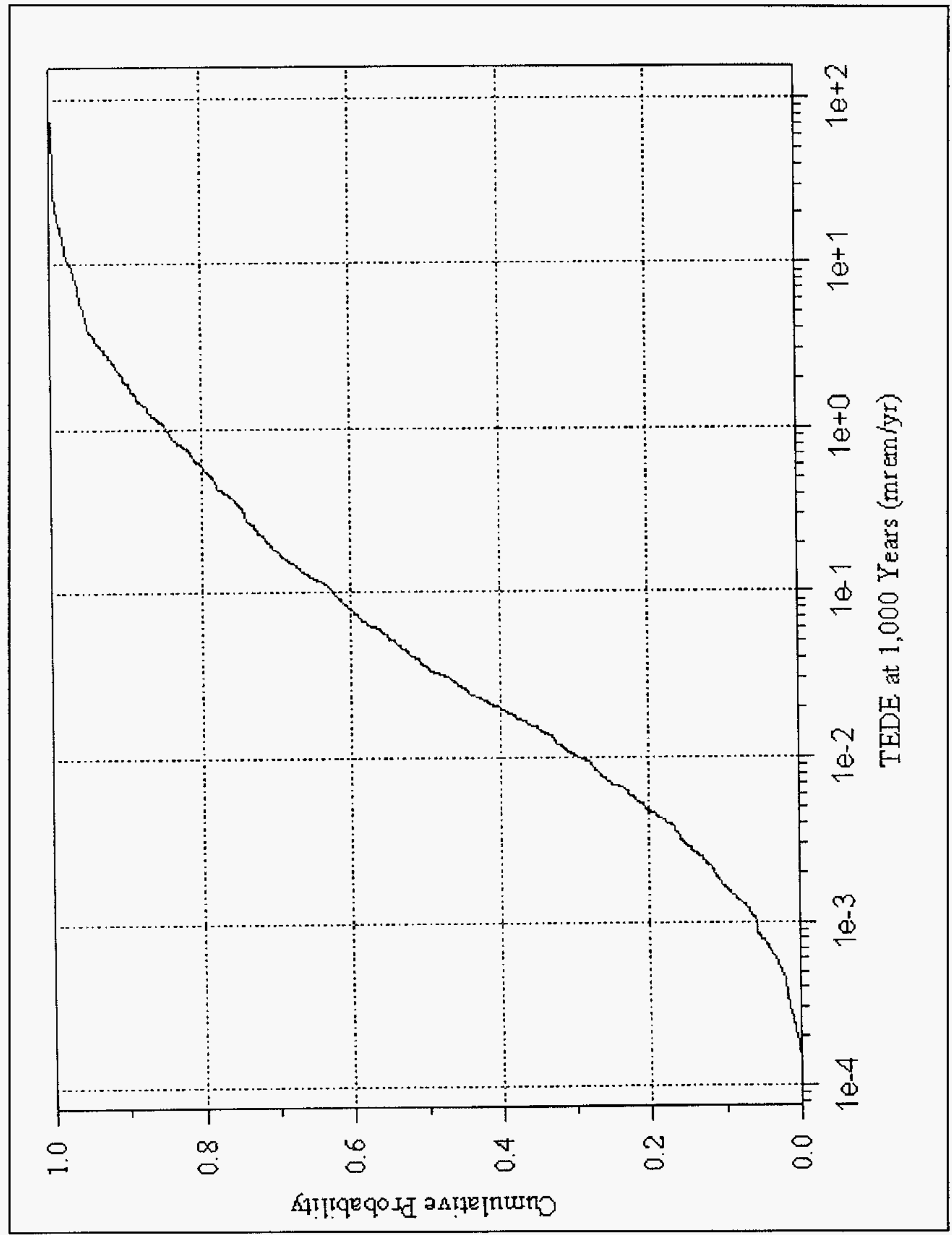

Figure 6.3 Cumulative Probability of 1,000 Monte Carlo Realizations of TEDE from Nonvolatile Radionuclides for a Resident at the Area 5 RWMS, 1,000 Years After Closure. 
that the dose constraint will not be exceeded throughout the compliance period. The TEDE from nonvolatile radionuclides is moderately sensitive to the cap thickness, the maximum depth of biological activity, the ${ }^{99} \mathrm{Tc}$ and ${ }^{36} \mathrm{Cl}$ plant-soil concentration ratio, and the ${ }^{99} \mathrm{Tc}$ and ${ }^{36} \mathrm{Cl}$ inventory. The ${ }^{99} \mathrm{Tc}$ inventory is very sensitive to the ${ }^{99} \mathrm{Tc}$ scaling factor for depleted uranium. The ${ }^{36} \mathrm{Cl}$ inventory is very sensitive to the inventory of mixed fission products and gross activity disposed from 1961 to 1978.

The effect of parameter uncertainty on the volatile radionuclide release model results was investigated at 100 and 250 years (Figure 6.4). All important transport parameters were sampled randomly. The SDCFs were held constant at the mean value. All realizations of the volatile radionuclide model were less than the 30 -mrem dose constraint. The TEDE from volatile radionuclides at 100 years is very sensitive to the water content of the cap and the radionuclide inventory. From 250 to 1,000 years after closure, the dose is dominated by ${ }^{14} \mathrm{C}$, whose release is constrained by the inventory. Therefore, the parameter uncertainty in the volatile radionuclide TEDE over this period is dominated by uncertainty in the ${ }^{14} \mathrm{C}$ inventory. The ${ }^{14} \mathrm{C}$ inventory is very sensitive to the inventory of mixed fission products and gross activity disposed from 1961 to 1978 , and moderately sensitive to the ${ }^{14} \mathrm{C}$ scaling factor for mixed fission products.

\subsection{Results for Contaminated Soil Corrective Action Units}

The TEDE for the Frenchman Flat playa soil site and the GMX soil site was estimated for a resident living within the contaminated area. The resident is assumed to be exposed to soil having a concentration equal to the area weighted mean concentration. After 250 years of institutional control, short-lived fission and activation products decay to negligible levels and the contaminated soil CAU inventories contain predominantly isotopes of plutonium and ${ }^{241} \mathrm{Am}$. The TEDE from such an inventory decreases very slowly over a 1,000-year compliance period (Table 6.4). The mean TEDE for a resident in the Frenchman Flat playa soil site and GMX soil site is 4 and $6 \mathrm{mrem} / \mathrm{yr}$, respectively, at 250 years. The dose is contributed primarily by inhalation of ${ }^{239} \mathrm{Pu}$.

The mean and 95th percentile emission rates were estimated for transport off site (Table 6.5). The highest annual emission rate, $74 \mu \mathrm{Ci} / \mathrm{yr}$, was estimated for ${ }^{239} \mathrm{Pu}$ at the $\mathrm{GMX}$ soil site.

\subsubsection{Uncertainty and Sensitivity}

The results for the Frenchman Flat playa soil site and the GMX soil site are expected to be sensitive to the radionuclide soil concentrations. Uncertainty in the future state of the soil contamination sites contributes to uncertainty in the final soil concentrations. Both sites are subject to the FFACO and will be closed under a RCRA-like process. DOE will not release these sites for public access until the requirements of DOE Order 5400.5 are met (DOE, 1990). Any future environmental restoration activity is likely to reduce the dose expected for these sites. In addition, the analysis uses an area weighted mean concentration and ignores the spatial variability of concentration within the CAUs. Small areas with higher concentrations may exist 


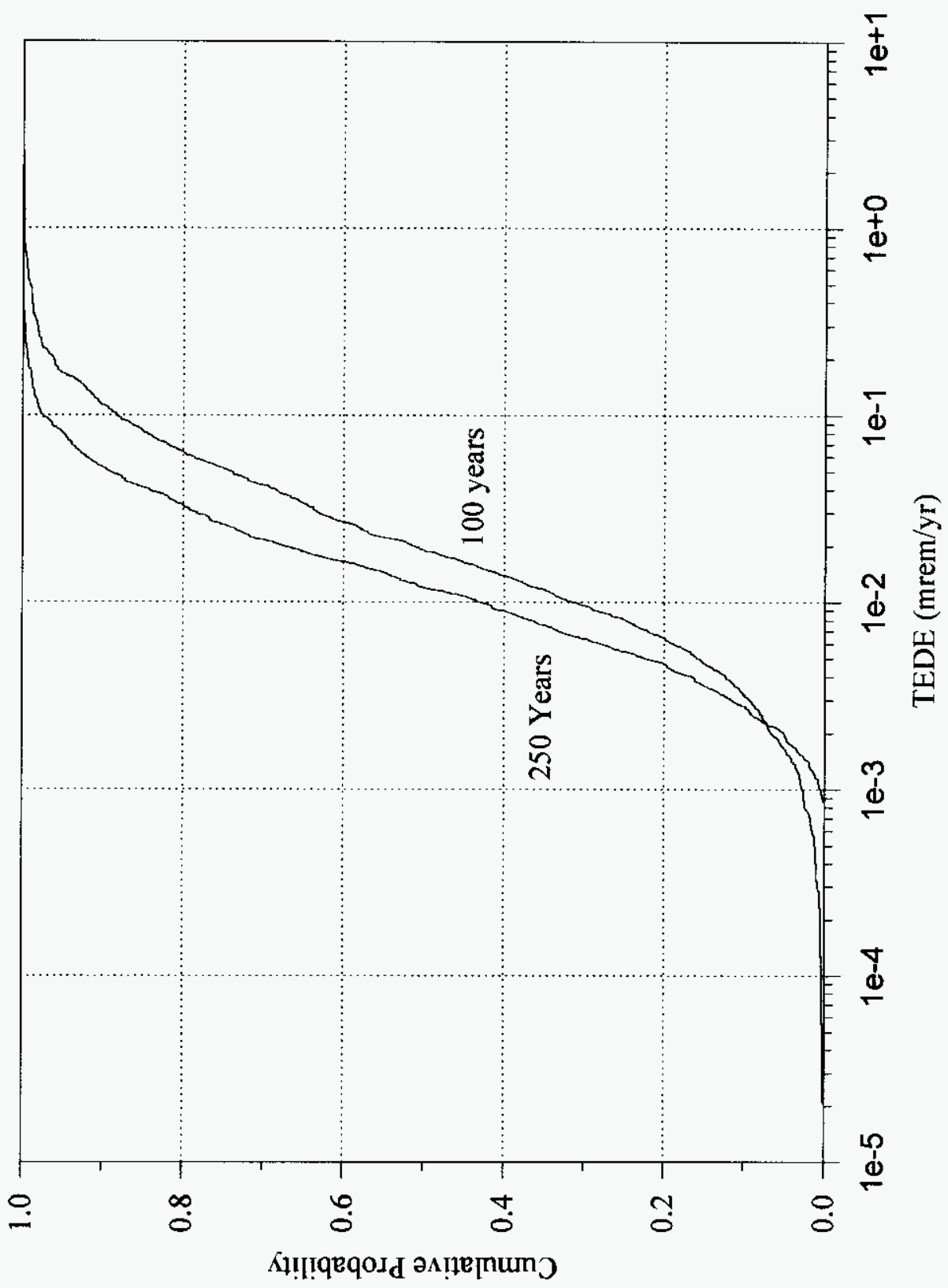

Figure 6.4 
Table 6.4 Mean and 95th Percentile Total Effective Dose Equivalent to a Resident Living in the Frenchman Flat Playa Soil Site and the GMX Soil Site at 250 and 1,000 Years After Closure

\begin{tabular}{|c|c|c|c|c|}
\hline \multirow[b]{2}{*}{$\begin{array}{l}\text { Years After } \\
\text { Closure }\end{array}$} & \multicolumn{2}{|c|}{ GMX Soil Site } & \multicolumn{2}{|c|}{ Frenchman Flat Playa Soil Site } \\
\hline & $\begin{array}{l}\text { Mean } \\
\text { (mrem/yr) }\end{array}$ & $\begin{array}{l}95 \text { th Percentile } \\
\text { (mrem/yr) }\end{array}$ & $\begin{array}{l}\text { Mean } \\
\text { (mrem/yr) }\end{array}$ & $\begin{array}{l}\text { 95th Percentile } \\
\text { (mrem/yr) }\end{array}$ \\
\hline 250 & 6 & 10 & 4 & 8 \\
\hline 1,000 & 5 & 8 & 3 & 7 \\
\hline
\end{tabular}

Table 6.5 Radionuclide Emission Rates for the Frenchman Flat Playa Soil Site and the GMX Soil Site at 1,000 Years After Closure

\begin{tabular}{|c|c|c|c|c|}
\hline \multirow[b]{2}{*}{ Nuclide } & \multicolumn{2}{|c|}{ GMX Soil Site } & \multicolumn{2}{|c|}{ Frenchman Flat Playa Soil Site } \\
\hline & $\begin{array}{l}\text { Mean } \\
{\left[\mathrm{Ci} /\left(\mathrm{m}^{2} \mathrm{~s}\right)\right]}\end{array}$ & $\begin{array}{l}95 \text { th Percentile } \\
{\left[\mathrm{Ci} /\left(\mathrm{m}^{2} \mathrm{~s}\right)\right]}\end{array}$ & $\begin{array}{l}\text { Mean } \\
{\left[\mathrm{Ci} /\left(\mathrm{m}^{2} \mathrm{~s}\right)\right]}\end{array}$ & $\begin{array}{l}95 \text { th Percentile } \\
{\left[\mathrm{Ci} /\left(\mathrm{m}^{2} \mathrm{~s}\right)\right]}\end{array}$ \\
\hline${ }^{239} \mathrm{Pu}$ & $1.3 \mathrm{e}-18$ & $5.1 \mathrm{e}-18$ & $7.7 \mathrm{e}-19$ & $3.0 \mathrm{e}-18$ \\
\hline${ }^{240} \mathrm{Pu}$ & $2.6 \mathrm{e}-19$ & $9.9 \mathrm{e}-19$ & $1.5 \mathrm{e}-19$ & $6.0 \mathrm{e}-19$ \\
\hline${ }^{24 i} \mathrm{Am}$ & $5.5 \mathrm{e}-20$ & $2.1 \mathrm{e}-19$ & $2.7 \mathrm{e}-20$ & $1.0 \mathrm{e}-19$ \\
\hline
\end{tabular}

within these sites, especially at the GMX soil site. The TEDE represents an expected dose for an average resident. These higher-concentration areas are most likely to be remediated in the future. The results are relatively insensitive to the date that institutional control ends because the soil concentrations will change little over the 1,000-year compliance period. The results are expected to be sensitive to the future land use of the site. The TEDE is calculated for a residential scenario with agriculture, which is considered a low probability bounding scenario. A part-time recreational use scenario or industrial scenario, which would yield a lower dose, is much more likely. The results for the Frenchman Flat playa soil site should be especially conservative. A playa is an extremely unlikely site for a residential scenario. In addition, the TEDE is primarily caused by inhalation of ${ }^{239} \mathrm{Pu}$. The airborne concentration of plutonium at atmospheric testing sites tends to be lower than expected because the plutonium is bound in large, fused soil particulates that are not easily resuspended and inhaled. The assessment ignores this effect and further overestimates the potential doses.

The effects of parameter uncertainty were investigated by propagating input parameter uncertainty through the model by Monte Carlo simulation. Parameters sampled randomly were the radionuclide inventories, the depth distribution of soil contamination (i.e., inverse relaxation length), soil bulk density, and ${ }^{240} \mathrm{Pu}$ mass abundance. The SDCFs were held constant at the mean value. The 95th percentile TEDE for the Frenchman Flat playa soil site and the GMX soil site was 7 and $8 \mathrm{mrem} / \mathrm{yr}$, respectively, at 1,000 years (Figure 6.5). The Frenchman Flat playa soil site results were very sensitive to the inverse relaxation length and moderately sensitive to the 


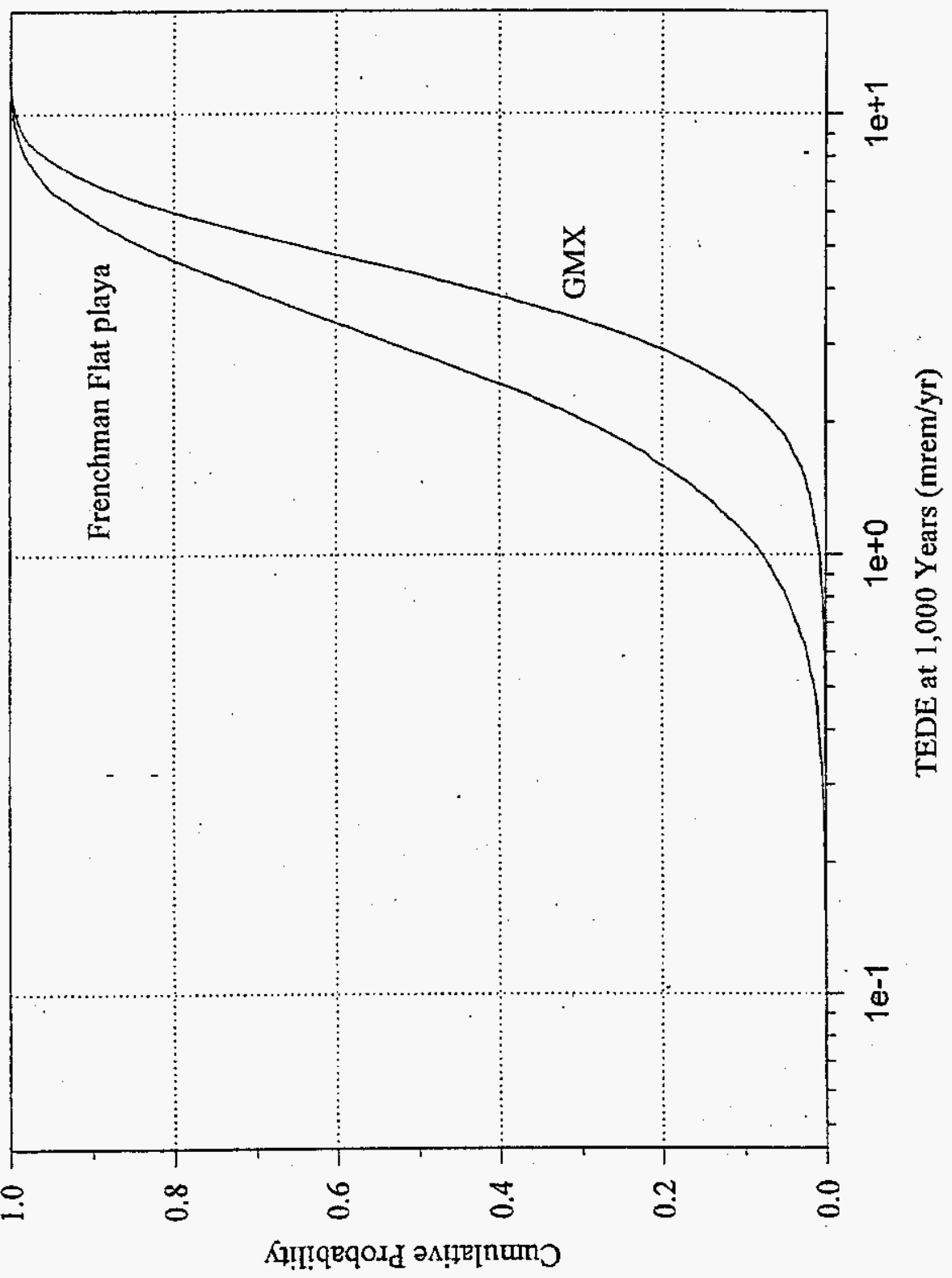

Figure 6.5

Cumulative Probability of 10,000 Monte Carlo Realizations of TEDE at 1,000 Years for a Resident at the Frenchman Flat Playa soil site and GMX soil site. 
${ }^{239} \mathrm{Pu}$ inventory. The GMX soil site results were very sensitive to the ${ }^{239} \mathrm{Pu}$ inventory and moderately sensitive to the inverse relaxation length. All realizations of TEDE were less than the 30-mrem dose constraint for both CAUs, indicating a high probability of compliance.

\subsection{Results for Areas Not Within Contaminated Soil Sites}

Residents not living directly in a contaminated soil site may be exposed to emissions of radionuclides from these sites. The airborne concentrations and long-term soil deposition at the off-site locations was estimated with the ISCLT computer code. Emissions from the Area 5 RWMS increase over the compliance period, while emissions from contaminated soil sites remain relatively constant. Therefore, the maximum dose at off-site locations was assumed to occur at the end of the 1,000-year compliance period. The highest ${ }^{239} \mathrm{Pu},{ }^{240} \mathrm{Pu}$, and ${ }^{241} \mathrm{Am}$ airborne concentrations and deposition rates occur near the GMX soil site. The highest concentrations of all other radionuclides are expected near the Area 5 RWMS because this is the only source. The maximum mean TEDE at 1,000 years was 0.2 mrem in a year and occurred near the GMX soil site. Ninety-eight percent of the dose is attributable to ${ }^{239} \mathrm{Pu},{ }^{240} \mathrm{Pu}$, and ${ }^{241} \mathrm{Am}$. Less than 2 percent of the dose is attributable to fission and activation products $\left({ }^{14} \mathrm{C},{ }^{99} \mathrm{Tc}\right.$, and $\left.{ }^{36} \mathrm{Cl}\right)$ released from the Area 5 RWMS.

\subsubsection{Uncertainty and Sensitivity}

The uncertainty in the TEDE at off-site locations was evaluated by calculating a bounding estimate using the 95th percentile contaminated soil site emission rates. The maximum estimated TEDE increases to $0.7 \mathrm{mrem} / \mathrm{yr}$ when the 95 th percentile emission rates are used. Uncertainty in the atmospheric dispersion model was not evaluated. Atmospheric dispersion models have been reported to give long-term average concentrations that are within a factor of three of the observed value (NCRP, 1984). The ISCLT estimated atmospheric ${ }^{239,}{ }^{240} \mathrm{Pu}$ concentration near the Area $5 \mathrm{RWMS}(3 \mathrm{e}-18 \mu \mathrm{Ci} / \mathrm{ml})$ is in reasonable agreement with the mean 1998 environmental monitoring result, $5 \mathrm{e}-18 \mu \mathrm{Ci} / \mathrm{ml}$ (DOE, 1999c). Considering the additional uncertainty contributed by the atmospheric dispersion model, there appears to be a high probability that the TEDE in off-site areas will remain below the $30 \mathrm{mrem}$ in a year dose constraint throughout the compliance period. 


\subsection{INTERPRETATION OF RESULTS}

Chapter 6 reported the TEDE expected for a resident living in a contaminated soil site (i.e., the Area 5 RWMS, the Frenchman Flat playa soil site, and the GMX soil site) and at locations outside the contaminated soil sites. The results indicate that there is a high probability that the annual TEDE in all four areas is less than the 30 -mrem dose constraint. This chapter integrates the results from the interacting sources and compares the result with the dose limit and dose constraint. An overview of the option chosen by the NNSA/NV to manage the UGTA source in Frenchman Flat is provided.

\subsection{Total Effective Dose Equivalent From Interacting Sources}

This section discusses the TEDE expected for combined exposure to the Area 5 RWMS, the Frenchman Flat playa soil site, and the GMX soil site. The TEDE received by a hypothetical resident of Frenchman Flat will vary with location and over time. The TEDE has been estimated for all locations throughout Frenchman Flat. The change in TEDE over time is different at the various contaminated soil sites because of the different radionuclide compositions and release processes. Overall however, the TEDE is relatively insensitive to time over the period from 250 to 1,000 years after closure. The TEDE from the Area 5 RWMS is expected to increase over time. The TEDE from the Frenchman Flat playa soil site and the GMX soil site is expected to decrease slightly over time. Compliance is evaluated at 1,000 years because this is the time within 250 to 1,000 years after closure when the maximum dose is expected.

The TEDE from interacting source terms can be estimated by summing the results for the individual contaminated sites and the results for the off-site locations obtained from the ISCLT model. The TEDEs from the individual sources are plotted in Figure 7.1 to indicate the spatial distribution and potential interaction of the sources. The highest TEDE is expected for a resident in the GMX soil site. The mean TEDE at this location from all evaluated sources is expected to be less than $6 \mathrm{mrem}$ in a year. Therefore, compliance with the $100-\mathrm{mrem}$ dose limit and 30 mrem dose constraint is reasonably assured for the contaminated soil sites considered.

The results indicate that there is relatively little interaction between any of the contaminated soil sites. The sites interact through the atmospheric pathway only. Within a contaminated soil site, the atmospheric contribution from the other sites is small relative to the dose from the underlying soil source. The contribution of the interacting sources at the Area 5 RWMS is less than 5 percent of the total TEDE. Therefore, the risks posed by the Area 5 RWMS, the Frenchman Flat playa soil site, and the GMX soil site can be managed independently. Continuing operation of the Area 5 RWMS is unlikely to have any effect on the remediation options chosen for the Frenchman Flat playa soil site and the GMX soil site. Conversely, the existence of the Frenchman Flat playa soil site and the GMX soil site, in their current unremediated condition, places no significant restrictions on the operation of the Area 5 RWMS. 


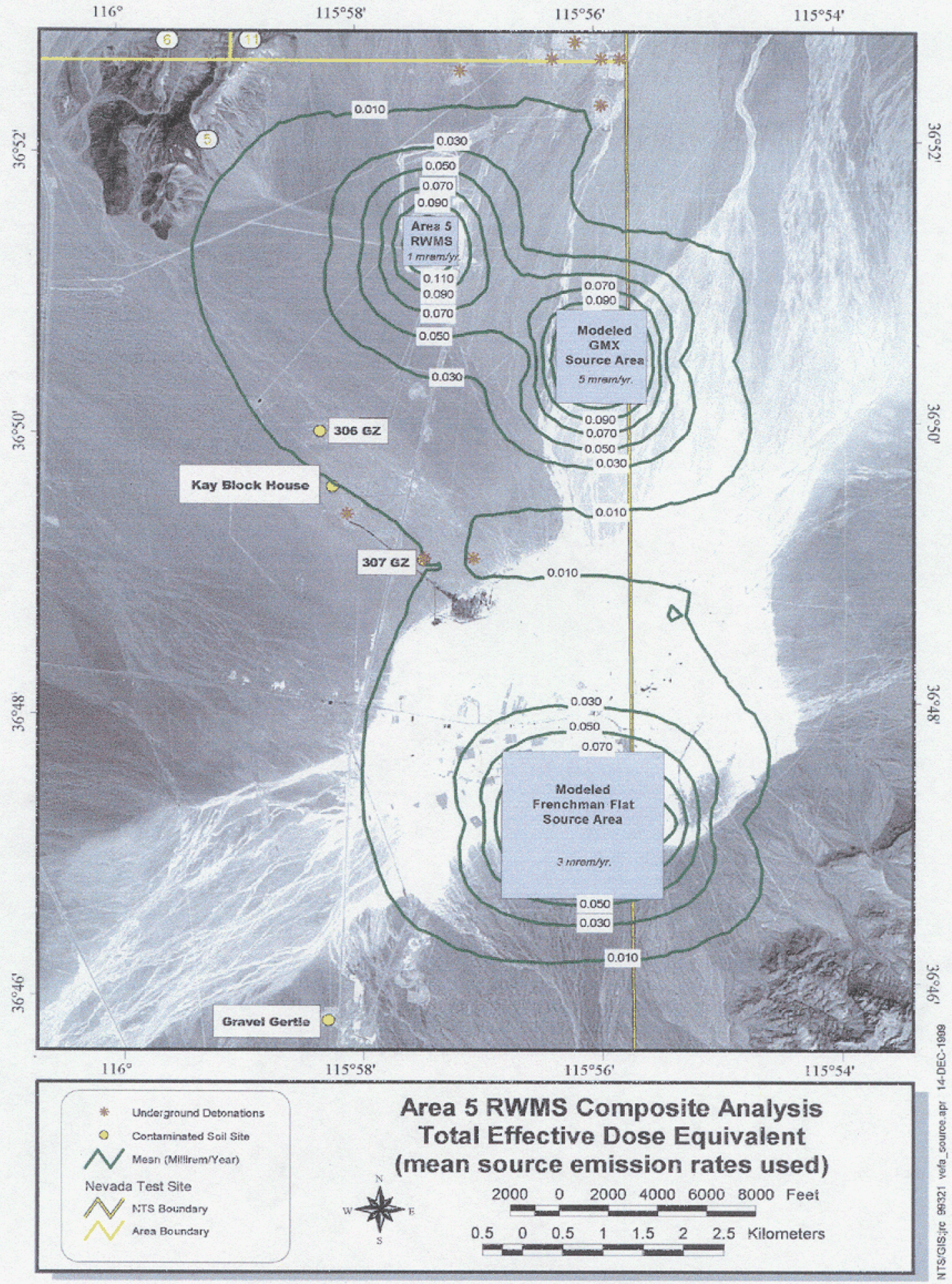

Figure 7.1 Mean Integrated Total Effective Dose Equivalent Estimated for Frenchman Flat at 1,000 Years. 
Several smaller sources close to the Frenchman Flat playa soil site were initially excluded from the CA based on their small inventories, small area, and distance from the Area 5 RWMS. These were the $306 \mathrm{GZ}$, the $307 \mathrm{GZ}$, the Kay Block House, and the Gravel Gertie sites (Figure 7.1). The low potential for interaction among the contaminated soil sites evaluated in the CA supports the conclusion that the contribution from these lesser sites is also negligible and can be ignored.

The potential still exists for interaction between the Frenchman Flat UGTA and any of the contaminated soil sites, including the Area 5 RWMS. Reasonable assurance cannot be provided that the combined dose from the contaminated soil sites and the Frenchman Flat UGTA are less than 100 mrem in a year at all locations in Frenchman Flat. Remediation and closure of the Frenchman Flat UGTA will be conducted under the FFACO by DOE/NV, with oversight from NDEP. Because no feasible, cost-effective technology exists for remediation of the UGTA source, natural attenuation will be used to reduce the dose from contaminated groundwater migrating from the UGTA source to $4 \mathrm{mrem} / \mathrm{yr}$ over the next 1,000 years (DOE, 1999a). The technical basis for the 4-mrem/yr boundary will be developed by DOE/NV in a Corrective Action Decision Document (CADD). The CADD will be subject to review and approval by NDEP. Land use within the $4 \mathrm{mrem} / \mathrm{yr}$ boundary may be controlled by restricting all public access or by restricting subsurface intrusion and groundwater use.

If future land-use restrictions are assumed to be effective, the maximum TEDE from the Frenchman Flat UGTA outside the restricted area will be limited to $4 \mathrm{mrem}$ in a year. As the TEDE from the contaminated soil sites is less than 26 mrem in a year, the dose from all interacting sources at sites outside the UGTA restricted area will likely be less than 30 mrem in a year. Although the TEDE at contaminated soil sites falling within the UGTA restricted area cannot be estimated at this time, land-use restrictions should eliminate the potential for exposure to contaminated groundwater. Therefore, as long as the UGTA land-use restrictions are maintained, it appears likely that the dose to a member of public will remain below the CA dose limit and dose constraint.

The decision identified in the DQO processes was to determine if continuing operation of the Area 5 RWMS poses an unreasonable risk to the health and safety of the public considering all interacting sources of residual radioactive material. The decision rule was that continuing operation would represent an unreasonable risk if the TEDE exceeded 100 mrem in a year. Risk management options were to be selected and implemented if the dose was greater than 100 mrem in a year. If the dose was between 30 and 100 mrem in year, management options were to be implemented if cost-effective options could be identified through an options analysis.

Reasonable assurance of compliance with the 100-mrem dose limit cannot be provided at this time because of uncertainty in the dose from the Frenchman Flat UGTA. It appears, however, that the TEDE can be limited to less than $100 \mathrm{mrem}$ in a year if the UGTA program establishes and maintains a restricted area around the Frenchman Flat UGTA that limits groundwater doses to 4 mrem in a year. This conclusion supports a decision to continue operations at the Area 5 RWMS. 


\subsection{Uncertainty and Sensitivity}

The uncertainty and sensitivity of the combined results can be understood qualitatively by evaluating uncertainty and sensitivity of the individual results and their relative contribution to the integrated dose. The Frenchman Flat UGTA, whose dose has not been estimated, and the GMX soil site make the largest potential contributions to the dose. The integrated results should have the same sources of uncertainty as the results for these individual sources. Major sources of uncertainty, ranked by their significance, are summarized below.

\subsubsection{Land-Use Boundaries}

The future location of land-use boundaries is a potential source of uncertainty. A major source of uncertainty for future land-use boundaries is the Frenchman Flat UGTA. The magnitude and direction of the hydraulic gradient of the uppermost aquifer in northern Frenchman Flat is poorly known because it is too small to be accurately measured. The radionuclide inventory of the Frenchman Flat UGTA remains classified and the release rates of radionuclides from the test debris is poorly understood. Because of these and other uncertainties, the direction, extent, and radionuclide concentration of groundwater contaminant plumes originating from the Frenchman Flat UGTA can not be estimated at this time. Additional site characterization and data analysis is planned to reduce these uncertainties. The DOE will continue to control land use on the NTS into the foreseeable future. Therefore, it is expected that the UGTA source can be managed through land use or groundwater use restrictions designed to limit the dose from groundwater to 4 mrem in a year. Outside the land-use boundaries, it is possible that doses could be increased by up to 4 mrem in a year.

Other areas potentially requiring long-term land-use restrictions are small portions of the Frenchman Flat playa soil site and the GMX soil site. Future remediation is expected to eliminate the need for controls of the contaminated soil sites. The CA results are an initial conservative estimate of the potential dose from the contaminated soil sites, assuming loss of land-use controls and no remediation.

\subsubsection{Final Closure of the Area 5 Radioactive Waste Management Site}

The CA assumes that final closure of the Area 5 RWMS will minimize infiltration of flood water into the disposal site, eliminating the potential for a groundwater pathway at the site. Failure of the flood control berm and below-grade subsidence of the cap could initiate a groundwater pathway and cause higher doses. Development of final closure plans and the technical basis for cap performance will strengthen and support the CA results. The Area 5 RWMS PA established that a minimum cap thickness of $4 \mathrm{~m}(13 \mathrm{ft})$ was required to ensure protection of intruders. The CA supports the conclusion that a cap 2 to $6 \mathrm{~m}(6$ to $20 \mathrm{ft})$ thick is sufficient to retard upward release of radionuclides. The final closure plan must consider these results and the potential effects of subsidence and erosion on cap thickness. The CA results should be revised when the final closure plan is available. Higher doses are unlikely if the final closure cap is designed to compensate for subsidence. 


\subsubsection{Remediation and Closure of the Gadgets, Mechanics, and Explosives Soil Site}

The future state of the GMX soil site is an important source of uncertainty in the CA results. The GMX soil site will be remediated and closed by DOE/NV with oversight by NDEP under the FFACO. The CA assumes exposure to an area weighted mean ${ }^{239} \mathrm{Pu}$ concentration that is approximately $23 \mathrm{pCi} / \mathrm{g}$. Similar sites on the Tonopah Test Range have been cleaned to a $200 \mathrm{pCi} / \mathrm{g}$ standard. If a similar standard is adopted for the GMX soil site, small areas may exist where doses would exceed the CA estimate. The CA results should be revised when the state of the GMX soil site at closure has been defined. Doses higher than estimated in the CA may be possible, but will be limited to small areas. Because these areas would be small, the probability that a resident would be present is also very small.

\subsubsection{Land Use}

The CA results are sensitive to the future land use assumed for Frenchman Flat. The CA assumes that the land is used for residential purposes. A permanent residence at these sites is a relatively low-probability event because of the remoteness and lack of water resources. The CA results should be conservative. Recreational or industrial uses, which would give lower doses, are much more likely for these sites.

\subsubsection{Model Parameter Uncertainty}

The parameter uncertainty of the TEDE was estimated by combining the 95 th percentile results from the individual sites. The highest dose is expected for the GMX soil site (Figure 7.2). The upper bound annual TEDE for the GMX soil site at 250 years is expected to be less than 11 mrem. The GMX soil site radionuclide inventory was an important source of parameter uncertainty in the TEDE calculated for the GMX soil site.

\subsection{Options Analysis}

Reasonable assurance of compliance with the 100-mrem dose limit cannot be provided at this time because of uncertainty in the dose from the Frenchman Flat UGTA. Compliance with the 100-mrem dose limit and 30-mrem dose constraint is possible if restrictions on the use of groundwater impacted by the Frenchman Flat UGTA are implemented and maintained.

Nevertheless, it can be concluded that the Area 5 RWMS is a suitable site for LLW management considering all interacting sources of radioactive material, and that continuing operation of the Area 5 RWMS will have negligible impacts on environmental management decisions regarding sources of radioactive contamination within the Frenchman Flat basin.

If the estimated dose cannot be shown to be less than 100 mrem in a year, the CA analysis guidance requires that an options analysis be conducted to identify management options for reducing future doses. Uncertainty in the dose from the Frenchman Flat UGTA is the primary 


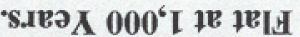

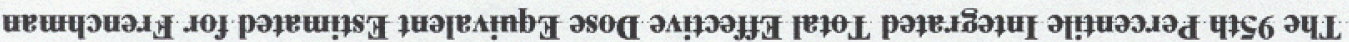

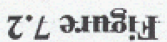

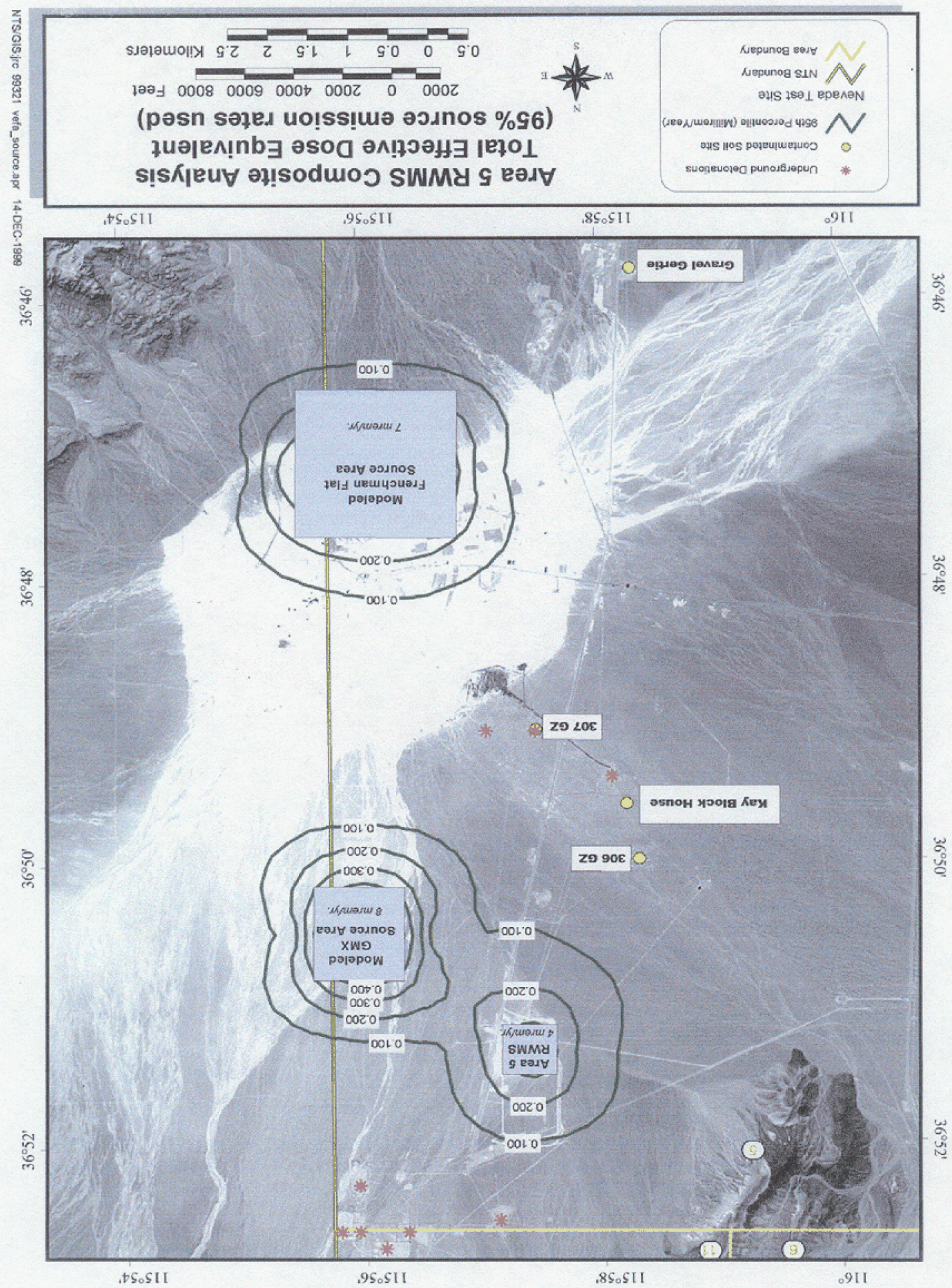


reason it is impossible to provide reasonable assurance of compliance at this time. Implementation of any management option for the other sources (i.e., the Area 5 RWMS, Frenchman Flat playa soil site, and the GMX soil site) will have no significant effect on the CA conclusions, because the uncertainty in the UGTA dose will still make it impossible to demonstrate compliance. Therefore, the only reasonable management options at this time are those that address management of the Frenchman Flat UGTA soil site.

The management option for the Frenchman Flat UGTA has been chosen by the DOE/NV UGTA Program through the FFACO process. This process involves review and approval by the state of Nevada and the input of stakeholders and external peer reviewers. The approach of the UGTA Program is to use natural attenuation and land-use restrictions to reduce groundwater doses, because remediation of the UGTAs is considered economically infeasible. The first step in the UGTA Program strategy is to develop a CAU model using existing data and predict the contaminant boundary in the groundwater. The contaminant boundary is defined as the location where a 4-mrem/yr dose is expected at the 50 percent confidence level over a period of 1,000 years. An initial iteration of this step has been completed. An external peer review of the results concluded that the existing data were not sufficient and that additional site characterization data were needed. The next step planned by the UGTA Program is to develop new site characterization data and a new CAU model. When the new data and CAU model are available, a contaminant boundary will be identified. The results of the evaluation will be documented in a CADD, tentatively scheduled for completion in 2003. The CADD and the selected contaminant boundary are subject to review and approval by NDEP. After issuance of the CADD, a program of monitoring and model validation will be implemented. The CA analysis will be updated when the CADD is issued and approved. 


\section{This Page Intentionally Left Blank}




\subsection{PREPARERS}

\subsection{Principal Investigators}

\section{Vefa Yucel}

M.S. Civil Engineering, Iowa State University, Ames

B.S. Civil Engineering, Iowa State University, Ames

Vefa Yucel is a registered Civil Engineer/hydrologist with 25 years of experience in environmental and engineering hydraulics/hydrology. He completed pre-doctoral course work in the Civil Engineering Department at Stanford University, with special emphasis on simulation and stochastic processes in hydrology. He managed the Hydraulics/ Hydrology/Modeling group in the Geotechnical and Hydraulic Engineering Services section at Bechtel's Oak Ridge office. The group provided specialty service to environmental restoration and waste management projects in surface water and groundwater hydrology, fate and transport modeling, geochemistry, and geostatistics. His recent project experience includes flow and transport modeling for the siting and licensing of the low-level radioactive waste disposal facility in Nebraska for the Central Interstate Compact, hydrologic investigations and flow and transport modeling for risk assessments at several sites of the DOE's Formerly Used Sites Remedial Action Program project, and the risk assessments and hydrologic modeling for the Oak Ridge National Laboratory Remedial Investigation/Feasibility Study project.

Mr. Yucel served as the technical lead for the Composite Analysis. He performed the transport modeling for the nonvolatile radionuclides and atmospheric dispersion modeling.

\section{Beth A. Moore}

M.S. Hydrology, University of Idaho

B.S. Geology and Marine Sciences, Pennsylvania State University

Associate Computer Programming, Midland College, Texas

Beth Moore is a hydrogeologist and has served as the DOE/NV Project Manager for Low-Level Waste Performance Assessments and Site Characterization in the Waste Management Program for over two years. She served as the technical lead to conduct the expert panel elicitation to determine the probability of inadvertent human intrusion into radioactive waste management sites at the Nevada Test Site. Ms. Moore has over 16 years of consulting and contracting experience in support of the DOE and the EPA in the areas of waste site field characterization, groundwater flow and transport modeling, groundwater monitoring and protection, and database management. Her Master's Thesis work was completed at the DOE Hanford Site in the areas of aquifer characterization, radionuclide migration, and surface geophysical mapping. 
This Page Intentionally Left Blank 


\subsection{REFERENCES}

Anderson, A. O., and D. M. Allred, 1964. "Kangaroo Rat Burrows at the Nevada Test Site." Great Basin Naturalist 24:93-101.

Anspaugh, L. R., J. H. Shinn, P. L. Phelps, and N. C. Kennedy, 1975. "Resuspension and Redistribution of Plutonium in Soils." Health Physics 29: 571-582.

Atwood, C. L., and C. L. Hertzler, 1989. Review of Selected Radiation Monitoring Results at and Near the Radioactive Waste Management Site of the Nevada Test Site, 1970-1988. EGG-SARE-8555. EG\&G Idaho, Inc., Idaho Falls, Idaho.

Barbour, M. G., 1973. "Desert Dogma Reexamined: Root/Shoot Productivity and Plant Spacing." Am. Mid. Nat. 89(1):41-57.

BN (Bechtel Nevada), 1998. Nevada Test Site Routine Radiological Environmental Monitoring Plan. DOE/NV/11718--244. Bechtel Nevada, Las Vegas, Nevada.

- 1997. Groundwater Monitoring Report for the Area 5 Radioactive Waste Management Site. Bechtel Nevada, Las Vegas, Nevada.

Black, P., K. Black, M. Hooten, L. Mathai, and D. Neptune, 1998. Assessing the Probability of Inadvertent Human Intrusion at the Nevada Test Site Radioactive Waste Management Sites, Vol. 1. DOE/NV--593. Neptune and Company, Inc., Los Alamos, New Mexico.

Blout, D. O., W. S. Birchfiel, D. P. Hammermeister, and K. A. Zukosky, 1995. Site Characterization Data from the Area 5 Science Boreholes, Nevada Test Site, Nye County, Nevada. DOE/NV/11432-170. U. S. Department of Energy, Nevada Operations Office, Las Vegas, Nevada.

Chapman, J. B., 1995. "Evaporation Calculations at the Area 5 Radioactive Waste Management Site Based on Stable Isotope Data." Letter Report from Desert Research Institute to T. Brown, Sandia National Laboratories, November 14, 1995.

—_, 1997. "Evaporation Calculations at the Area 3 Radioactive Waste Management Site Based on Stable Isotope Data." Letter Report from Desert Research Institute to B. Moore, Department of Energy, Nevada Operations Office, March 13, 1997.

- 1998. Personal Communication from J. B. Chapman to S. C. Mehrotra, April 16, 1998.

Chew, R. M., and A. E. Chew, 1965. "The Primary Productivity of a Desert-Shrub (Larrea Tridentata) Community." Ecological Monographs 35(4):355-375. 
Chu, M. S., and E. A. Bernard, 1991. Waste Inventory and Preliminary Source Term Model for the Greater Confinement Disposal Site at the Nevada Test Site. SAND91-0170. Sandia National Laboratories, Albuquerque, New Mexico.

Clements, W. E., and M. H. Wilkening, 1974. "Atmospheric Pressure Effects on ${ }^{222}$ Rn Transport Across the Earth-Air Interface." J. of Geophysical Research 79(33):5025-5029.

Cline, J. F., K. A. Gano, and L. E. Rogers, 1980. "Loose Rock as Biobarriers in Shallow Land Burial." Health Physics 39: 497-504.

Cochran, J., 1997. Personal communication from J. Cochran to G. Shott, December 9, 1997.

DOC (U.S. Department of Commerce), 1987. Census of Agriculture, Vol. 1, Geographical Area Series, Part 28, Nevada. U.S. Government Printing Office, Washington, D.C.

DOE (U.S. Department of Energy), 2000. United States Nuclear Tests, July 1945 Through September 1992. DOE/NV--209 (Rev. 15). U.S. Department of Energy, Nevada Operations Office, Las Vegas, Nevada.

- 1999a. Accelerating Cleanup: Paths to Closure. DOE/NV--586, U.S. Department of Energy, Nevada Operations Office, Las Vegas, Nevada.

, 1999b. Corrective Action Investigation Plan for Corrective Action Unit 98: Frenchman Flat. DOE/NV--478, Revision 1. U.S. Department of Energy, Nevada Operations Office, Las Vegas, Nevada.

- 1999c. Nevada Test Site Annual Site Environmental Report for Calendar Year 1998. DOE/NV/1 1718--361. U.S. Department of Energy, Nevada Operations Office, Las Vegas, Nevada. In preparation.

-, 1998a. Nevada Test Site Resource Management Plan. DOE/NV--518. U.S.

Department of Energy, Nevada Operations Office, Las Vegas, Nevada.

, 1998b. Consequences of Subsidence for the Area 3 and Area 5 Radioactive Waste Management Sites, Nevada Test Site. DOE/NV--502, UC-600. U.S. Department of Energy/Nevada Operations Office, Las Vegas, Nevada.

, 1997a. Nevada Test Site Annual Site Environmental Report for Calendar Year 1996. DOE/NV/11718--137. U.S. Department of Energy, Nevada Operations Office, Las Vegas, Nevada. , 1997b. Regional Groundwater Flow and Tritium Transport Modeling and Risk Assessment of the Underground Test Area, Nevada Test Site, Nevada. DOE/NV--477. U.S. Department of Energy, Nevada Operations Office, Las Vegas, Nevada. 
1997c. Final Waste Management Programmatic Environmental Impact Statement for Managing, Treatment, Storage, and Disposal of Radioactive and Hazardous Waste, Vols. $I-V$. DOE/EIS-0200-F. U.S. Department of Energy, Washington, DC.

1996a. Guidance for a Composite Analysis of the Impact of Interacting Source Terms of the Radiological Protection of the Public from Department of Energy Low-Level Waste Disposal Facilities. U.S. Department of Energy, Washington, D.C.

, 1996b. Interim Format and Content Guide and Standard Review Plan for U.S.

Department of Energy Low-Level Waste Disposal Facility Performance Assessments. U.S. Department of Energy, Washington, D.C.

, 1996c. Final Environmental Impact Statement for the Nevada Test Site and Offsite Locations in the State of Nevada, August 1996. DOE/EIS 0243. U.S. Department of Energy, Nevada Operations Office, Las Vegas, Nevada.

, 1996d. Environmental Impact Statement for the Nevada Test Site and Off-Site Locations in the State of Nevada (NTS EIS) Record of Decision (ROD). U.S. Department of Energy, Nevada Operations Office, Las Vegas, Nevada.

, 1996e. Nevada Environmental Restoration Project Federal Facility Agreement and Consent Order (FFACO), as amended. U.S. Department of Energy, Nevada Operations Office, Las Vegas, Nevada.

, 1995a. "Inclusion of Pre-1988 Source Term and Other Sources of Radioactive Contamination in Low-Level Waste Disposal Facility Performance Assessments." Memorandum from J. Lytle to Distribution, May 31, 1995.

, 1995b. Implementation Plan for Defense Nuclear Facility Safety Board

Recommendation 94-2, Conformance with Safety Standards at Department of Energy LowLevel Nuclear Waste and Disposal Sites. U.S. Department of Energy, Washington, D.C.

, 1990. Order 5400.5, "Radiation Protection of the Public and the Environment." U.S. Department of Energy, Washington, D.C.

1988. Order 5820.2A, "Radioactive Waste Management." U.S. Department of Energy, Washington, D.C.

EPA (U.S. Environmental Protection Agency), 1998. Part 141, National Primary Drinking Water Regulations. Title 40, Code of Federal Regulations, Part 141, U. S. Environmental Protection Agency, Washington, D.C.

1995. User's Guide for the Industrial Source Complex (ISC3) Dispersion Models Volume I - User Instructions. EPA-454/B-95-003a. U.S. Environmental Protection Agency, Research Triangle Park, North Carolina. 
—_ 1994. Guidance for the Data Quality Objective Process. EPA/600/R-96/055. U.S. Environmental Protection Agency, Washington, D.C.

, 1984. Population Distribution Around the Nevada Test Site. EPA-600/4-84-067.

Environmental Monitoring Systems Laboratory, Las Vegas, Nevada.

1979. AIRDOS-EPA: A Computerized Methodology for Estimating Environmental Concentrations and Dose to Man from Airborne Releases of Radionuclides. EPA 520/179-009. U.S. Environmental Protection Agency, Washington, D.C.

Gilbert, R. O., 1977. "Revised Total Amounts of ${ }^{239,240} \mathrm{Pu}$ in Surface Soil at Safety-Shot Sites, pp. 423-430. In: M. G. White, P. B. Dunaway, and D. L. Wireman, (eds)., Transuranics in Desert Ecosystems. NVO-181. U.S. Department of Energy, Nevada Operations Office, Las Vegas, Nevada.

Gustafson, D. L., S. E. Rawlinson, and J. J. Miller, 1993. Summary of Natural Resources That Potentially Influence Human Intrusion at the Area 5 Radioactive Waste Management Site, DOE/Nevada Test Site, Nye County Nevada. Raytheon Services Nevada, Las Vegas, Nevada.

Istok, J. D., D. O. Blout, L. Barker, K. R. Johnejack, and D. P. Hammermeister, 1994. "Spatial Variability in Alluvium Properties at a Low-Level Nuclear Waste Site. Soil Sci. Soc. Am. J. 58(4):1040-1051.

IT (International Technology Corporation), 1999. External Peer Review Group Report on Frenchman Flat Data Analysis and Modeling Task, Underground Testing Area Project, Rev. 0. ITLV/13052-077. IT Corporation, Las Vegas, Nevada.

Klepper, E. L., K. A. Gano, and L. L. Cadwell, 1985. Rooting Depth and Distributions of DeepRooted Plants in the 200 Area Control Zone of the Hanford Site. PNL-5247. Pacific Northwest Laboratory, Richland, Washington.

Laczniak, R. J., J. C. Cole, D. A. Sawyer, and D. A. Trudeau, 1996. "Summary of Hydrogeologic Controls on Ground-Water Flow at the Nevada Test Site, Nye County, Nevada." U.S. Geological Survey Water-Resources Investigation Report 967-4109. U.S. Geological Survey, Carson City, Nevada.

Link, S. O., W. J. Waugh, J. L. Downs, M. E. Thiede, J. C. Chatters, and G. W. Gee, 1994. "Effects of Coppice Dune Topography and Vegetation on Soil Water Dynamics in a ColdDesert Ecosystem." J. of Arid Environments 27: 265-278.

McArthur, R. D., 1991. Radionuclides in Surface Soil at the Nevada Test Site. DOE/NV/10845-02. Desert Research Institute, Water Resources Center, University of Nevada, Las Vegas, Nevada. 
McGrew, J. C., 1979. “Vulpes macrotis.” Mammalian Species 123:1-6.

Nazaroff, W. W., 1992. "Radon Transport From Soil to Air." Reviews of Geophysics 30(2): $137-160$.

NCRP (National Council on Radiation Protection and Measurements), 1987. Ionizing Radiation Exposure of the Population of the United States. NCRP Report No. 93, Bethesda, Maryland.

1984. Radiological Assessment: Predicting the Transport, Bioaccumulation, and Uptake by Man of Radionuclides Released to the Environment. NCRP Report No. 76, Bethesda, Maryland.

REECo (Reynolds Electrical \& Engineering Co.), 1993a. "Site Characterization and Monitoring Data from the Area 5 Pilot Wells, Nevada Test Site, Nye County, Nevada." REECo, Las Vegas, Nevada.

_ 1993b. "Hydrogeologic Data for Science Trench Boreholes at the Area 5 Radioactive Waste Management Site, Nevada Test Site, Nye County, Nevada." Special Projects Section, Environmental Restoration \& Technology Development Department, REECo, Las Vegas, Nevada.

1993c. "Hydrogeologic Data for Existing Excavations at the Area 5 Radioactive Waste Management Site, Nevada Test Site, Nye County, Nevada." Special Projects Section, Environmental Restoration \& Technology Development Department, REECo, Las Vegas, Nevada.

Reynolds, T. D., and J. W. Laundre, 1988. "Vertical Distribution of Soil Removed by Four Species of Burrowing Rodents in Disturbed and Undisturbed Soils." Health Physics 54(4): $445-450$.

Reynolds, T. D., and W. L. Wakkinen, 1987. "Characteristics of the Burrows of Four Species of Rodents in Undisturbed Soils in Southwestern Idaho." Am. Mid. Nat. 118(2): 245-250.

Richard-Haggard, K., 1983. Economic Potential of Alternative Land and Natural Resources Uses at the Nevada Test Site, Nye County, Nevada. Publication No. 45030, Desert Research Institute, University of Nevada System, Las Vegas, Nevada.

Rothermich, N. E., and A. T. Vollmer, 1986. Analysis of Soils From the Area 5 Radioactive Waste Management Site: A Comparison of 1979 and 1984 Data. RWM-8. Reynolds Electrical \& Engineering Co., Inc., Las Vegas, Nevada. 
RSN (Raytheon Services Nevada), 1991a. "Surficial Geology of the Area 5 Radioactive Waste Management Site and Vicinity, Nevada Test Site: Interim Report Review Draft." Environmental Safety and Health Division, Environmental Operations Department, Raytheon Services Nevada, Las Vegas, Nevada.

1991b. "Compiled and Interpreted Geological Cross Sections for Frenchman Flat for the Integrated Site Assessment and Characterization (ISAAC) of Area 5 - Nevada Test Site." Environmental Safety and Health Division, Environmental Operations Department, Raytheon Services Nevada, Las Vegas, Nevada.

Shott, G. J., L. E. Barker, S. E. Rawlinson, and M. J. Sully, 1997a. Performance Assessment for the Area 5 Radioactive Waste Management Site at the Nevada Test Sites, Nye County Nevada. Revision 2.I. Bechtel Nevada, Las Vegas, Nevada.

Shott, G. J., V. Yucel, M. J. Sully, L. E. Barker, S. E. Rawlinson, and B. A. Moore, 1997b. Performance Assessment/Composite Analysis for the Area 3 Radioactive Waste Management Site at the Nevada Test Sites, Nye County Nevada. Revision 2.0. Bechtel Nevada, Las Vegas, Nevada.

Shott, G. J., C. J. Muller, L. E. Barker, D. E. Cawlfield, F. T. Lindstrom, D. G. Linkenheil, M. J. Sully, L. McDowell-Boyer, and D. J. Thorne, 1995. Performance Assessment for the Area 5 Radioactive Waste Management Site at the Nevada Test Sites, Nye County Nevada. Revision 2.0. DOE/NV/11432--196. Reynolds Electrical and Engineering Co., Las Vegas, Nevada.

Tabler, R. D., 1964. "The Root System of Artemisia Tridentata at 9,500 Feet in Wyoming." Ecology 45(3): 633-636.

Tyler, S. W., J. B. Chapman, S. H. Conrad, D. P. Hammermeister, D. O. Blout, J. J. Miller, M. J Sully, J. M. Ginanni, 1996. "Soil-Water Flux in the Southern Great Basin, United States: Temporal and Spatial Variations Over the Last 120,000 Years. Water Resources Research 32(6):1481-1499.

Tompson, Andrew F. B.; Bruton, Carol J.; and Pawloski, Gayle A., 1999. Evaluation of the Hydrologic Source Term from Underground Nuclear Tests in Frenchman Flat at the Nevada Test Site: The CAMBRIC Test. UCRL-ID-132300. Lawrence Livermore National Laboratory, Livermore, California.

US Ecology, 1989. "California Low-Level Radioactive Waste Disposal Facility License Application." US Ecology, Newport Beach, California.

Wallace, A., E. M. Romney, and J. W. Cha, 1980. "Depth Distribution of Roots of Some Perennial Plants in the Nevada Test Site Area of the Northern Mojave Desert." Great Basin Nat. Mem 4:301-207. 
Wallace, A., S. A. Bamberg, and J. W. Cha, 1974. "Quantitative Studies of Roots of Perennial Plants in the Mojave Desert." Ecology 55: 1160 - 1162.

Winsor, T. F., and F. W. Whicker, 1980. "Pocket Gophers and Redistribution of Plutonium in Soil." Health Physics 39: 257-262. 


\section{This Page Intentionally Left Blank}




\section{APPENDIX 1 \\ COMPOSITE ANALYSIS INVENTORY}




\section{CONTENTS}

A1.1 Radiological Operations Potentially Impacting the Area 5 Radioactive

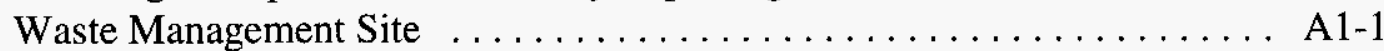

A1.2 Operating History of the Area 5 Radioactive Waste Management Site .... A1-2

A1.3 Data Quality Objectives ........................... A1-6

A1.4 Estimated Inventory of Contaminated Soil Sites ............... A1-9

A1.5 The Estimated Inventory of Waste Disposed at the Area 5 Radioactive

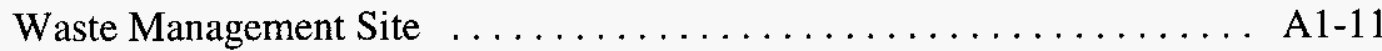

A1.5.1 Waste Disposal Records . . ................... A1-11

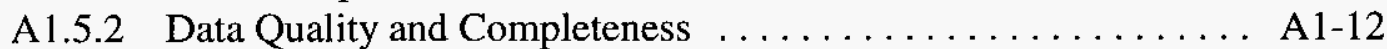

A1.5.3 Estimated Completeness of Data Base Records and Query Results ............................. A1-13

A1.5.4 Estimation of Radionuclide Inventory Disposed Before September 26, 1988, in the Shallow Pits and Trenches ....... A1-17

A1.5.5 Scaling Factors Used to Revise Radionuclide Composition ..... A1-19

A1.5.5.1 Scaling Factors for Mixed Fission Products and Activation Products .................. A1-19

A1.5.5.2 Scaling Factors for Fission Products and Transuranic Nuclides in Uranium .................. A1-21

A 1.5.5.3 Scaling Factors for Uranium Isotopes in Depleted and Enriched Uranium ................ A1-21

A1.5.5.4 Scaling Factors for Transuranic Nuclides in Scrap Plutonium ......................... A1-22

A1.5.6 Estimated Inventory for the Area 5 RWMS Shallow Pits and Trenches ........................... A1-24

A1.5.7 Estimated Inventory of the Greater Confinement Disposal and the Greater Confinement Disposal Test

A1.5.7.1 Estimated Volume of Greater Confinement Disposal and Greater Confinement Disposal Test Waste ...

A1.5.7.2 Final Inventory in Greater Confinement Disposal and the Greater Confinement Disposal Test ....... A $1-30$

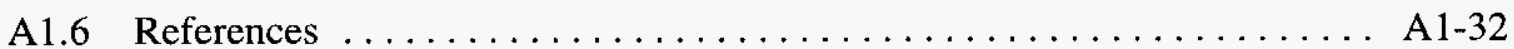




\section{List of Figures}

A1.1 Location and Status of Disposal Units at the Area 5 Radioactive Waste Management Site

A1.2 Estimated Mean Inventory Disposed in Shallow Pits and Trenches at the Area 5 RWMS as a Function of Time Considering Only Radioactive Decay and

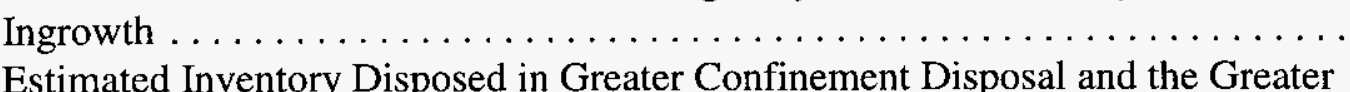

A1.3 Estimated Inventory Disposed in Greater Confinement Disposal and the
Confinement Disposal Test Boreholes at the Area 5 Radioactive Waste Management Site as a Function of Time Considering Only Radioactive Decay

\section{List of Tables}

A1.1 Operational Status and Dimensions of Unclassified Shallow Pits and Trenches at the Area 5 RWMS

A1.2 Operational Status and Dimensions of Classified Shallow Pits and Trenches

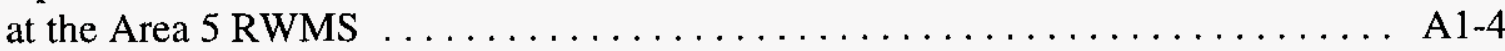

A1.3 Operational Status of GCD Boreholes at the Area 5 RWMS $\ldots \ldots \ldots \ldots \ldots$ A1-7

A1.4 Contaminated Soil Sites Within Areas 5 and 11 Characterized by the Radionuclide Inventory and Distribution Program and the Nevada Applied Ecology Group . . . . . . . . . . . . . . . . . . . . A 1-10

A1.6 Facility Design Factors, Waste-Filled Trench Dimensions, and Below-Grade Cap Thicknesses Assumed to Estimate the Volume of Waste Disposed Before September 26, 1988

A1.7 Total External Volume and Activity Retrieved From Queries of Waste Management Data Bases

A1.8 Mean and Standard Deviation Assumed for Activity Fractions of Radionuclides in Gross Activity or Mixed Fission Products Disposed in the Shallow Pits and Trenches at the Area 5 RWMS Before September 26, 1988

A1.9 Assumed Scaling Factors for Unreported Radionuclides in Uranium . . . . . . . . A A 1-22

A1.10 Assumed Mass Abundance of Transuranic Radionuclides in Scrap Plutonium . . . A1-23

A1.11 Deterministic Estimate of Inventory Disposed at the Area 5 RWMS in the Shallow Pits and Trenches Before September 26, 1998

A1.12 Estimated Mean and Standard Deviation of Area 5 RWMS Inventory at Closure in 2028 for Radionuclides Meeting Screening Criteria . . . . . . . . . . . A1-27

A1.13 Estimated Inventory for the Area 5 RWMS GCD and GCDT Boreholes ....... A1-31 


\section{ACRONYMS}

$\begin{array}{ll}\text { ALARA } & \text { As Low As Reasonably Achievable } \\ \text { ANSI } & \text { American National Standards Institute } \\ \text { BN } & \text { Bechtel Nevada } \\ \text { CA } & \text { Composite Analysis } \\ \text { CAS } & \text { Corrective Action Site } \\ \text { CAU } & \text { Corrective Action Unit } \\ \text { DQO } & \text { Data Quality Objective } \\ \text { DRI } & \text { Desert Research Institute } \\ \text { FEMP } & \text { Fernald Environmental Management Program } \\ \text { FIDLER } & \text { field instrument for determination of low-energy radiation } \\ \text { GCD } & \text { Greater Confinement Disposal } \\ \text { GCDT } & \text { Greater Confinement Disposal Test } \\ \text { GMX } & \text { Gadgets, Mechanics, and Explosives } \\ \text { GZ } & \text { ground zero } \\ \text { MFP } & \text { mixed fission product } \\ \text { NAEG } & \text { Nevada Applied Ecology Group } \\ \text { NTS } & \text { Nevada Test Site } \\ \text { PA } & \text { Performance Assessment } \\ \text { RIDP } & \text { Radionuclide Inventory and Distribution Program } \\ \text { RSL } & \text { Remote Sensing Laboratory } \\ \text { RWMS } & \text { Radioactive Waste Management Site } \\ \text { TEDE } & \text { total effective dose equivalent } \\ \text { TRU } & \text { transuranic waste } \\ \text { UGTA } & \text { Underground Test Area } \\ \text { WMDB } & \text { Waste Management Data Base } \\ \end{array}$




\section{This Page Intentionally Left Blank}




\section{A1.0 INTRODUCTION}

This Appendix summarizes the inventory of radioactive materials evaluated in the Composite Analysis (CA) for the Area 5 Radioactive Waste Management Site (RWMS). It begins in Sections A1.1 and A1.2 by summarizing radiological operations in Frenchman Flat and surrounding areas that potentially contribute to the source term. Section A1.3 describes the application of the data quality objectives (DQO) process to inventory development. Finally, Sections A1.4 and A1.5 describe the data sources and estimated inventories for the contaminated soil sites, the shallow pits and trenches at the Area 5 RWMS, and the Greater Confinement Disposal (GCD) boreholes.

\section{A1.1 Radiological Operations Potentially Impacting the Area 5 Radioactive Waste Management Site}

Radioactive waste has been disposed at the Area 5 RWMS in northern Frenchman Flat since 1960. Contamination from radiological operations conducted in the Frenchman Flat basin are the most likely to interact with releases from the Area 5 RWMS.

Radiological operations on the Nevada Test Site (NTS) began in 1951 when Frenchman Flat and Yucca Flat were transferred to the Atomic Energy Commission for nuclear weapon testing. From 1951 to 1962,14 atmospheric nuclear weapon tests were conducted at various elevations above Frenchman Flat playa in Area 5. Neutron activation of soils at the ground zero (GZ) and fallout of fission products, activation products, and unfissioned weapons components contaminated soils at five distinct GZs on the Frenchman Flat playa and over a plume extending east-northeast from the playa (McArthur and Mead, 1989).

Underground nuclear testing began in Frenchman Flat in 1965 and continued until 1971. Underground nuclear testing deposits fission products, activation products, and unfissioned weapons components into soil and groundwater, if present, surrounding the test zero point. During some underground tests, borehole containment failed and test debris was promptly released to the atmosphere. Test debris and drilling fluids from core sampling performed after the test may also contaminate surface soils around the GZ. Ten underground nuclear tests were conducted in Frenchman Flat in Areas 5 and 11. In 1965, three underground nuclear tests were conducted approximately 3.8 to 4.2 kilometers $(\mathrm{km})(2.4$ to 2.6 miles [mi]) south of the Area 5 RWMS at a site northwest of the Frenchman Flat playa. Containment failed during two of the three tests (U.S. Department of Energy [DOE], 2000). From 1966 to 1971, seven underground nuclear tests were conducted 1.5 to $3.0 \mathrm{~km}(0.9$ to $1.9 \mathrm{mi})$ northeast of the Area $5 \mathrm{RWMS}$ on the boundary between Areas 5 and 11. Containment is reported to have failed for all seven tests (DOE, 2000). Nine of the 10 underground tests in Frenchman Flat were conducted in the valley fill alluvium and one (PIN STRIPE) was conducted in the tuff aquifer. A single underground test conducted south of the Area 5 RWMS (CAMBRIC) was conducted below the water table. All of the remaining tests were conducted within $100 \mathrm{~m}(330 \mathrm{ft})$ of the water table. 
Frenchman Flat has also been the site of equation-of-state tests, which involve the nonnuclear destruction of nuclear weapons components. From 1954 to 1956, 24 atmospheric equation-ofstate tests caused the dispersal of plutonium at the Gadgets, Mechanics, and Explosives (GMX) soil site (Corrective Action Unit [CAU] 365), located approximately $2.1 \mathrm{~km}(1.3 \mathrm{mi})$ southeast of the Area 5 RWMS. Hydrodynamic tests involving uranium has been preformed at several sites in Frenchman Flat.

Outside Frenchman Flat, the nearest radiologically contaminated sites are located in Plutonium Valley and Yucca Flat. In 1955 and 1956, four safety tests were conducted at the Project 56 site (CAU 366) in Plutonium Valley, approximately $13 \mathrm{~km}(8 \mathrm{mi})$ north of the Area 5 RWMS. The final Project 56 safety test is reported to have had a very slight nuclear yield (DOE, 2000). From 1951 to 1962, approximately 80 atmospheric nuclear weapons tests were conducted in Yucca Flat, $20 \mathrm{~km}(12 \mathrm{mi})$ north of the Area $5 \mathrm{RWMS}$. Yucca Flat has also been the site of hundreds of underground nuclear tests, conducted from 1957 to 1992 . The underground nuclear tests in Yucca Flat closest to the Area 5 RWMS are approximately $14 \mathrm{~km}(8.7 \mathrm{mi})$ to the northnorthwest.

\section{A1.2 Operating History of the Area 5 Radioactive Waste Management Site}

Radioactive wastes have been disposed at the Area 5 RWMS in two types of disposal units. Low-level radioactive waste has been disposed in shallow, unlined excavations ranging in depth from 4.5 to 15 meters $(\mathrm{m})$ (15 to 49 feet [ft]) deep, but typically $6 \mathrm{~m}(20 \mathrm{ft})$ deep. These disposal units are known as shallow pits or trenches, depending on their dimensions. In addition to lowlevel wastes, transuranic wastes (TRU) were inadvertently disposed in a single trench in 1986. Higher specific activity wastes, including some TRU and DOE waste similar to Nuclear Regulatory Commission (NRC) greater-than class $\mathrm{C}$ waste, have been disposed in uncased 36-m(118-ft)-deep boreholes. These boreholes are referred to as GCD.

Low-level radioactive waste disposal in shallow pits and trenches began at the Area 5 RWMS in 1960. From 1960 until 1978, wastes disposed at the Area 5 RWMS were generated predominantly on the NTS. During this period, 11 shallow pits and trenches were excavated. By 1978 , four unclassified trenches and four classified trenches had been filled and closed (Tables A1.1 and A1.2). In 1978, the Area 5 RWMS began accepting waste from off-site generators. From 1978 until the implementation of DOE Order 5820.2A, five additional trenches were excavated. Three unclassified trenches were filled and closed during this period. On September 26, 1988, a total of 11 pits and trenches had been filled and closed, 3 remained open and partially filled with waste, and 2 were open and empty (Tables A1.1 and A1.2). Figure A1.1 shows the location and status of the pits and trenches as of January 1998.

Disposal in GCD boreholes began in 1983 with the development of the Greater Confinement Disposal Test (GCDT). The GCDT was an instrumented GCD borehole used to demonstrate the 


\begin{tabular}{|c|c|c|c|c|c|c|c|}
\hline Table A1.1 & Operational & tatus and Dis & nsions of & sssified Shallo & $s$ and Tre & hes at the Ar & a 5 RWMS \\
\hline Disposal Unit & $\begin{array}{c}\text { Date } \\
\text { Opened }\end{array}$ & $\begin{array}{l}\text { Date } \\
\text { Closed }\end{array}$ & Status & $\begin{array}{l}\text { Assessment } \\
\text { Process }\end{array}$ & $\begin{array}{c}\text { Max. } \\
\text { Length } \\
\text { (m) }\end{array}$ & $\begin{array}{c}\text { Max. } \\
\text { Width (m) }\end{array}$ & $\begin{array}{c}\text { Mean Depth } \\
\text { Below Grade } \\
\text { (m) }\end{array}$ \\
\hline $\mathrm{T} 01 \mathrm{U}$ & $01 /-/ 1961$ & $07 /-/ 1965$ & Closed & $\mathrm{CA}$ & 85.4 & 18.6 & 4.6 \\
\hline $\mathrm{T} 06 \mathrm{U}$ & $05 /-/ 1965$ & $02 /-/ 1970$ & Closed & $\mathrm{CA}$ & 189.4 & 12.3 & 4.6 \\
\hline T07U & $09 / 04 / 1968$ & $12 / 21 / 1987$ & Closed & $\mathrm{CA}$ & 204.7 & 12.9 & 4.6 \\
\hline $\mathrm{T} 04 \mathrm{U}$ & $02 /-/ 1970$ & $12 /-/ 1978$ & Closed & $\mathrm{CA}$ & 192.0 & 15.1 & 4.6 \\
\hline $\mathrm{T} 02 \mathrm{U}$ & $12 /-/ 1972$ & $12 /-/ 1978$ & Closed & $\mathrm{CA}$ & 192.9 & 15.1 & 4.6 \\
\hline P01U & $11 / 01 / 1978$ & $04 / 18 / 1985$ & Closed & $\mathrm{CA}$ & 195.9 & 74.6 & 8.5 \\
\hline T03U & $-/-/ 1984$ & $10 / 15 / 1996$ & Closed & PA & 25.3 & 13.8 & 4.6 \\
\hline $\mathrm{P} 02 \mathrm{U}$ & $04 / 24 / 1985$ & $01 /-/ 1987$ & Closed & $\mathrm{CA}$ & 190.4 & 30.3 & 7.6 \\
\hline $\mathrm{P} 03 \mathrm{U}$ & $01 /-/ 1987$ & & Open & $\mathrm{CA} / \mathrm{PA}$ & 256 & 105.5 & 9.1 \\
\hline $\mathrm{P} 04 \mathrm{U}$ & $06 / 21 / 1988$ & $05 / 11 / 1995$ & Closed & $\mathrm{CA} / \mathrm{PA}$ & 304.8 & 61.0 & 6.1 \\
\hline P06U Upper & $-/-/ 1994$ & & Open & $\mathrm{PA}$ & 190 & 30 & 7.4 \\
\hline P06U Lower & $-/-/ 1994$ & & Open & $\mathrm{PA}$ & 183 & 6 & 14.6 \\
\hline $\mathrm{P} 05 \mathrm{U}$ & $02 / 23 / 1995$ & & Open & PA & 304.8 & 45.7 & 6.7 \\
\hline $\mathrm{P} 07 \mathrm{U}$ & $02 /-/ 1997$ & & Open & PA & 75.0 & 11.1 & 6.7 \\
\hline
\end{tabular}


Table A1. 2 Operational Status and Dimensions of Classified Shallow Pits and Trenches at the Area 5 RWMS

\begin{tabular}{cccccccc}
\hline & Date & $\begin{array}{c}\text { Date } \\
\text { Closed }\end{array}$ & Status & $\begin{array}{c}\text { Assessment } \\
\text { Process }\end{array}$ & $\begin{array}{c}\text { Max. } \\
\text { Length } \\
\text { (m) }\end{array}$ & $\begin{array}{c}\text { Max. } \\
\text { Width (m) }\end{array}$ & $\begin{array}{c}\text { Mean Depth } \\
\text { Below Grade } \\
\text { (m) }\end{array}$ \\
\hline T01C & $-/-/ 1960$ & $03 /-/ 1969$ & Closed & CA & 186.4 & 12.0 & 4.6 \\
T03C & $-/-/ 1960$ & $03 /-/ 1969$ & Closed & CA & 186.2 & 12.0 & 4.6 \\
T05C & $-/-/ 1960$ & $03 /-/ 1969$ & Closed & CA & 117.6 & 12.0 & 4.6 \\
T06C & $-/-/ 1960$ & $03 /-/ 1969$ & Closed & CA & 117.0 & 12.2 & 4.6 \\
T04C & $03 /-/ 1969$ & $08 / 03 / 1995$ & Closed & CA/PA & 205.7 & 17.5 & 6.1 \\
T04C-1 & $03 /-/ 1969$ & $08 / 03 / 1995$ & Closed & CA/PA & 57.9 & 9.7 & 4.6 \\
T02C & $12 / 05 / 1988$ & $7 / 22 / 1993$ & Closed & PA & 117.3 & 10.7 & 6.1 \\
T07C & $-/-/ 1995$ & & Open & PA & 195.1 & 15.2 & 4.6 \\
T08C & $-/-/ 1995$ & & Open & PA & 129.5 & 15.2 & 4.6 \\
T09C & $-/-11995$ & & Open & PA & 88.4 & 9.1 & 4.6 \\
\hline
\end{tabular}




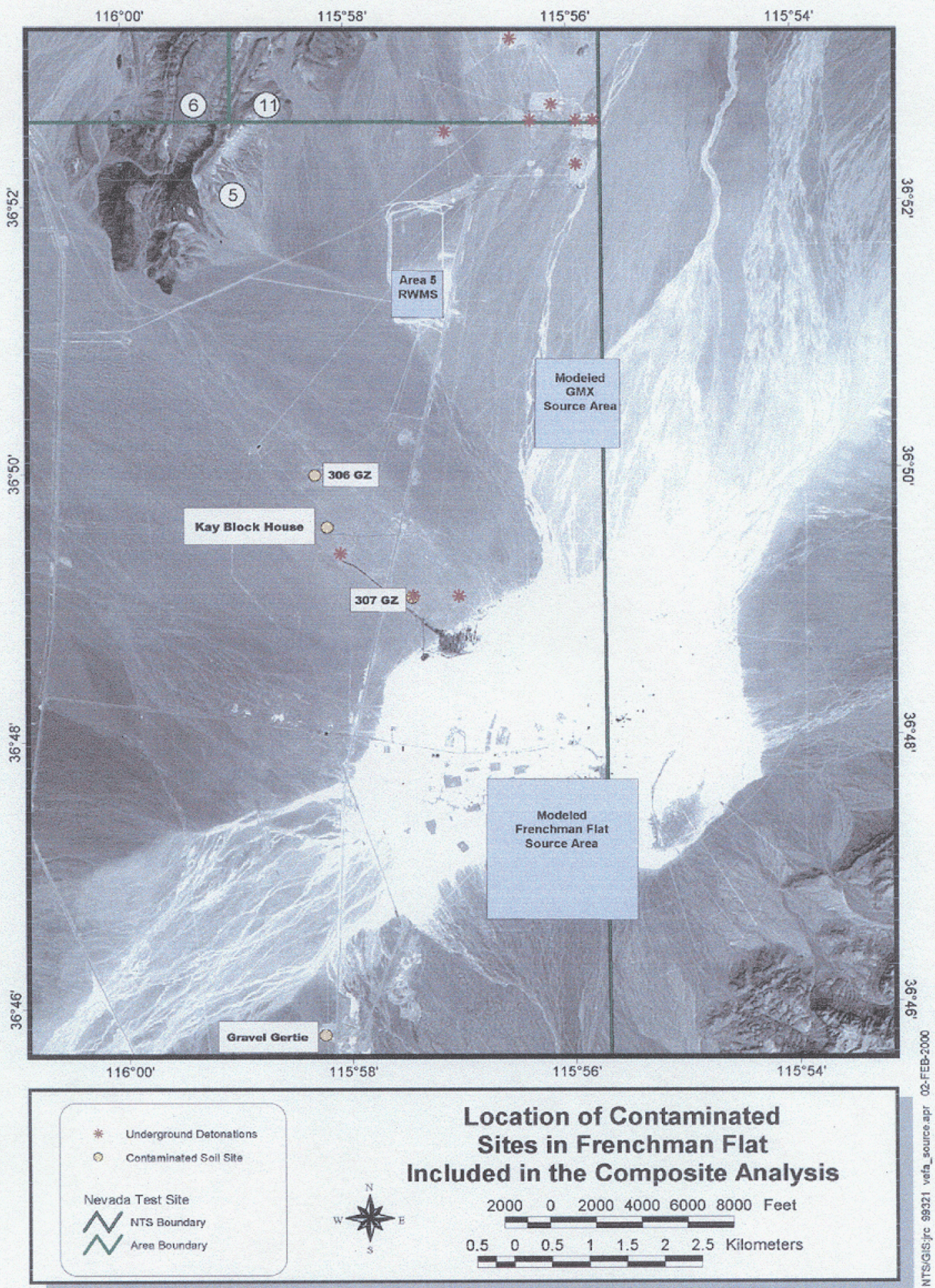

Figure A1.1 Location and Status of Disposal Units at the Area 5 Radioactive Waste Management Site. 
Table A1.3 Operational Status of GCD Boreholes at the Area 5 RWMS. Greater Confinement Disposal boreholes have a diameter of 3 or $3.6 \mathrm{~m}(10 \mathrm{ft})$, thickness of $15 \mathrm{~m}$ (49 ft), and a total volume of 106 or $158 \mathrm{~m}^{3}(3.7 \mathrm{e} 3 \mathrm{or}$ $\left.5.6 \mathrm{e} 3 \mathrm{ft}^{3}\right)$

\begin{tabular}{cccccc}
\hline GCD Borehole & Disposal Area & Date Opened & Date Closed & Status & Assessment Process \\
\hline U5RWMS01C & Classified & $-/-/ 1984$ & $-/-/ 1984$ & Closed & CA \\
U5RWMS02C & Classified & $-/-/ 1984$ & $-/-/ 1984$ & Closed & CA \\
U5RWMS03C & Classified & $-/-/ 1984$ & $-/-/ 1984$ & Closed & CA \\
U5RWMS04C & Classified & $07 / 19 / 1985$ & $01 / 14 / 1987$ & Closed & CA \\
U5RWMS05U & Unclassified & $02 / 05 / 1986$ & $04 / 08 / 1987$ & Closed & CA \\
U5RWMS06U & Unclassified & $07 / 16 / 1986$ & & Open (Inactive) & CA \\
U5RWMS07C & Classified & $07 / 07 / 1989$ & & Open (Inactive) & CA/PA \\
U5RWMS08C & Classified & $-/-/ 1987$ & & Open (Empty) & None Applicable \\
U5RWMS09U & Unclassified & $-/-/ 1987$ & & Open (Empty) & None Applicable \\
U5RWMS010U & Unclassified & $12 / 11 / 1987$ & $11 / 03 / 1989$ & Closed & CA/PA \\
U5RWMS011U & Unclassified & $-/-/ 1989$ & & Open (Empty) & None Applicable \\
U5RWMS012U & Unclassified & $-/-/ 1989$ & & Open (Empty) & None Applicable \\
GCDT & Unclassified & $-/-/ 1983$ & $-/-/ 1984$ & Closed & CA \\
\hline
\end{tabular}


- The required data is the inventory, concentration, and distribution of radioactive materials in Frenchman Flat and Plutonium Valley.

- All important sources of radioactive material in Frenchman Flat and Plutonium Valley are known.

- Remediation and closure of contaminated soil sites will occur under the Federal Facilities Agreement and Consent Order. Closure plans or cleanup levels have not been negotiated at this time. Therefore, the $\mathrm{CA}$ assumes that these sites will be unremediated at closure, based on DOE CA guidance.

- Site characterization data from the Radionuclide Inventory and Distribution Program (RIDP) and the Nevada Applied Ecology Group (NAEG) are the best inventory data source for contaminated soil sites.

- There is insufficient characterization data to adequately assess the risk posed by the UGTA CAUs. Reasonable assurance of compliance with the CA dose constraint and dose limit can not be provided for the UGTA CAUs at this time. Current land-use controls can eliminate public access to these areas. The risk can be characterized and management plans developed during the active institutional control period.

- Waste Management data base records are the best inventory data source for the Area 5 RWMS.

\section{Step 4: Definition of the Study Boundaries}

Existing environmental monitoring reports, risk assessments, and the Area 5 RWMS Performance Assessment $(\mathrm{PA})$ results provide a basis for identifying radionuclide inventories that are reasonably likely to interact with the Area 5 RWMS. The interacting inventories are assumed to be limited to contaminated soil CAUs and UGTA CAUs within Frenchman Flat and Plutonium Valley.

\section{Step 5: Develop a Decision Rule}

The initial CA will determine if there is reasonable assurance that the TEDE from all residual sources of radioactive materials is less than $30 \mathrm{mrem}$ in a year for potential future residents of Frenchman Flat. If the TEDE is less than $30 \mathrm{mrem}$ in a year at all locations, then a qualitative evaluation of as low as reasonably achievable (ALARA) requirements is all that is necessary. If the TEDE exceeds $30 \mathrm{mrem}$ in a year, then the CA will determine if there is reasonable assurance that the TEDE is less than $100 \mathrm{mrem}$ in a year. If there is reasonable assurance that the TEDE is less than $100 \mathrm{mrem}$ in a year, then an options analysis will be performed to identify cost-effective options that may reduce future doses. Options that may be considered include additional data collection and evaluation, future land-use control, and site remediation. If there is not reasonable assurance that the TEDE is less than $100 \mathrm{mrem}$ in a year, then cost-effective corrective action or additional data collection activities will be identified that may provide assurance of compliance with the $100 \mathrm{mrem}$ in a year dose limit.

The remainder of this report develops the inventory for an initial CA. The inventory and its uncertainty has been estimated for the identified sources from what is believed to be the best available data. Cost-effective data collection or data refinement activities can be identified with the help of the CA results. 


\section{A1.4 Estimated Inventory of Contaminated Soil Sites}

Several radiological site characterization projects have described residual radioactive contamination in Areas 5 and 11. These surveys have found significant residual contamination only at the Frenchman Flat playa soil site (CAU 106), the GMX soil site (CAU 365), the PIN STRIPE soil site (CAU 98, CAS 11-57-001), and the Plutonium Valley soil site (or Project 56 safety test site) (CAU 366). At the Area 5 RWMS, as at most sites throughout Frenchman Flat, soils contain levels of residual radioactive contamination characteristic of global fallout for the southwestern United States (Rothermich and Vollmer, 1986; Atwood and Hertzler, 1989).

The Bechtel Nevada (BN) Health Protection Department maintains a list of radiologically controlled areas. The list identifies nine contaminated soil sites in Area 5, including four sites on the Frenchman Flat playa, the 306 soil site, the 307 soil site, the Kay Block House, the Gravel Gertie, and GMX. Six sites associated with the Project 56 site are listed for Plutonium Valley in Area 11. In 1982, the Remote Sensing Laboratory (RSL) performed aerial radiation surveys of Areas 5 and 11 using $\mathrm{NaI}(\mathrm{Tl})$ detectors mounted on helicopters. Elevated gamma exposure rates from residual radioactive contamination were detected only at Frenchman Flat playa, the Kay Block House, GMX, PIN STRIPE, and the Project 56 site (McArthur and Mead, 1989).

Four radiologically controlled sites in Area 5 were excluded from the CA because of their comparatively small inventories, small contaminated area, and distance from the Area 5 RWMS. The excluded sites were the 306 soil site, the 307 soil site, the Kay Block House, and the Gravel Gertie. The inventories at these sites are poorly known, but are believed to be small based on the results of aerial surveys and the histories of the sites. The Kay Block House was reportedly used for hydrodynamic studies of depleted uranium targets (McArthur and Mead, 1989). The Kay Block House was detected by aerial gamma survey, but the contaminated area was relatively small. RIDP gamma surveys, which did not measure uranium or its progeny, found only low levels of fallout fission and activation products at the site. The Kay Block House was eliminated based on its comparatively small inventory and area. The other three excluded sources have not been characterized. The 306 soil site and the Gravel Gertie are believed to be contaminated with uranium from hydrodynamics studies. The 307 soil site is believed to be contaminated with debris from the DILUTED WATERS underground nuclear test. The inventories are assumed to be comparatively small because they could not be distinguished from background soil during aerial surveys. The areas of the undetected sites, which range from $3.7 \mathrm{e} 1$ to $2 \mathrm{e} 3$ square meters $\left(\mathrm{m}^{2}\right)\left(4 \mathrm{e} 2\right.$ to $2.2 \mathrm{e} 4$ square feet $\left.\left[\mathrm{ft}^{2}\right]\right)$, are significantly less than the Frenchman Flat playa soil site and GMX soil site which exceed $1 \mathrm{e} 6 \mathrm{~m}^{2}\left(1 \mathrm{e} 7 \mathrm{ft}^{2}\right)$. The undetected soil sites are all at least 4 to $13 \mathrm{~km}$ ( 2 to $8 \mathrm{mi}$ ) from the Area 5 RWMS. These sites have been excluded because of their distance from the Area 5 RWMS, small area, and comparatively small inventories relative to the Frenchman Flat playa soil site, the GMX soil site, the PIN STRIPE soil site, and the Plutonium Valley soil site. If sources with larger inventories (such as the Frenchman Flat soil site and the GMX soil site) are found to be significant contributors to the dose, then further evaluation of the excluded sources may be necessary. 
In 1970, the NAEG was formed to study the fate and transport of transuranics at the NTS and to estimate the inventory of transuranics at safety test sites. During the 1970 s, the NAEG characterized the GMX soil site and the Project 56 safety test sites using the Field Instrument for Determination of Low-Energy Radiation (FIDLER) and radiochemical analysis of soil samples. They estimated that the GMX soil site had a ${ }^{239,240} \mathrm{Pu}$ inventory of $1.5 \mathrm{Ci}$ and a 95 percent confidence ranging from 1.1 to $1.9 \mathrm{Ci}$ (Gilbert, 1977). The Project $56{ }^{239,240} \mathrm{Pu}$ inventory was estimated to be $36 \mathrm{Ci}$, with a 95 percent confidence interval ranging from 28 to $44 \mathrm{Ci}$ (Gilbert, 1977).

During the 1980s, the Desert Research Institute (DRI) began the RIDP survey of gamma-emitting radionuclides on the NTS with the intent of estimating the surface soil radionuclide inventory. Sampling locations and areas were selected based on the earlier RSL aerial surveys (Table A1.4). Barnes et al. (1980) described the distribution of gamma-emitting soil contamination at three GZs on the Frenchman Flat playa soil site. The Project 56 safety experiment test sites were surveyed in 1982 using gamma spectrometry, and again in 1989 using a FIDLER. In 1985 and 1986, DRI resurveyed the Frenchman Flat playa soil site and the GMX soil site using in situ gamma spectrometry and soil sampling. McArthur (1991) estimated the surface soil inventory for the Frenchman Flat playa soil site, the GMX soil site, the PIN STRIPE soil site, and the Plutonium Valley soil site (Table A1.5). McArthur's (1991) estimate of the GMX soil site inventory is in good agreement with the NAEG's earlier results (Gilbert, 1977). The initial gamma spectroscopy-based RIDP estimates for Project 56 were significantly less than the NAEG results (Gilbert, 1977; McArthur and Mead, 1989). The later RIDP FIDLER surveys gave higher results that fell just within the lower limit of the NAEG 95 percent confidence interval (McArthur and Mead, 1989). The area surveyed by the NAEG was approximately double that surveyed by the RIDP. The difference between the RIDP and NAEG results may indicate greater uncertainty in the Area $11 \mathrm{Pu}$ inventory because of uncertainty in the areal and depth distribution of the contamination.

Table A1.4 Contaminated Soil Sites Within Areas 5 and 11 Characterized by the Radionuclide Inventory and Distribution Program and the Nevada Applied Ecology Group (from McArthur and Mead, 1989)

\begin{tabular}{|c|c|c|c|c|c|c|c|c|}
\hline Area & Region & $\begin{array}{l}\text { Area } \\
\left(\mathbf{m i}^{2}\right)\end{array}$ & $\begin{array}{l}\text { Area } \\
\left(\mathbf{f t}^{2}\right)\end{array}$ & Area $\left(\mathrm{m}^{2}\right)$ & Easting & Northing & $\begin{array}{l}\text { Distance } \\
\text { from } \\
\text { RWMS } \\
\text { (mi) }\end{array}$ & $\begin{array}{l}\text { Distance } \\
\text { from } \\
\text { RWMS } \\
\text { (m) }\end{array}$ \\
\hline \multirow{2}{*}{5} & $\begin{array}{l}\text { Frenchman } \\
\text { Playa }\end{array}$ & 2.20 & $6.10 \mathrm{e}+07$ & $5.70 \mathrm{e}+06$ & 715200 & 747990 & 3.8 & 6200 \\
\hline & GMX & 0.70 & $2.00 \mathrm{e}+07$ & $1.80 \mathrm{e}+06$ & 714200 & 763200 & 1.3 & 2100 \\
\hline \multirow{3}{*}{11} & Pluton & & & & & & & \\
\hline & Valley & 3.37 & $9.40 \mathrm{e}+07$ & $8.73 e+06$ & 708000 & 809000 & 7.9 & 13000 \\
\hline & PIN STRIPE & 0.56 & $1.57 e+07$ & $1.46 e+06$ & 712000 & 778000 & 2.0 & 3200 \\
\hline
\end{tabular}


Table A1.5 Inventories in Curies Estimated by the Radionuclide Inventory and Distribution Program and the Nevada Applied Ecology Group for Contaminated Soil Sites in Areas 5 and 11 (from McArthur, 1991; Gilbert, 1977)

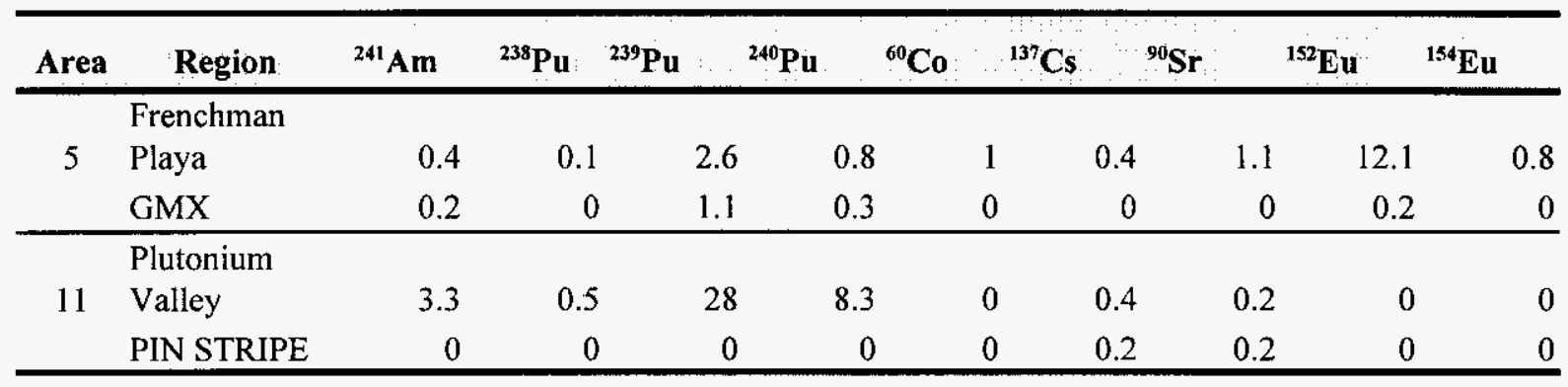

The RIDP data (McArthur, 1991) were selected as the CA data source for the Frenchman Flat playa soil site and the GMX soil site in Area 5 and the PIN STRIPE soil site in Area 11 because these data are the most current and are based on in situ gamma spectrometry and confirmatory soil sampling. The NAEG data reported by Gilbert (1977) were used for the Plutonium Valley soil site because these data were measured over a larger area and are more conservative. Both data sources report a single activity for ${ }^{239} \mathrm{Pu}$ and ${ }^{240} \mathrm{Pu}$. These nuclides were partitioned, assuming a 6 percent mass abundance of ${ }^{240} \mathrm{Pu}$.

McArthur (1991) reported, based on subjective judgment, that there was a 95 percent probability that the true radionuclide inventories were within a factor of two of the RIDP values. Therefore, the contaminated soil site inventories are assumed to be normally distributed with 95 percent confidence limits equal to 0.5 and 2 times the RIDP value. The 95 percent confidence interval reported by Gilbert (1977) was assumed for the Plutonium Valley soil site inventory.

\section{A1.5 The Estimated Inventory of Waste Disposed at the Area 5 Radioactive Waste Management Site}

This section estimates the inventory of wastes disposed from 1960 until September 26, 1988, in the shallow pits and trenches at the Area 5 RWMS using data retrieved from Waste Management data bases and from interviews with Waste Management staff. The total shallow pits and trenches inventory at the Area 5 RWMS at closure is estimated by combining the 1960 to September 26, 1988, inventory with the inventory estimated in the Area 5 RWMS PA (Shott et al., 1997). The GCD and GCDT inventory is derived from previous studies (Chu and Bernard, 1991).

\section{A1.5.1 Waste Disposal Records}

Waste disposal records have changed significantly in form, quality, and completeness during the period of operations from 1960 to September 26, 1988. The quality of current records is significantly improved from the quality of the older records discussed here. From January 1961 to August 1978, disposals were recorded in a typewritten logbook. The logbook records include 
date of receipt, source of the waste, identity of the waste, number and types of containers, total volume, total activity, burial site, and date of disposal. In 1996, the logbook entries were entered into an electronic data base.

Beginning in 1978, waste disposals were recorded directly in an electronic data base known as the Waste Management Data Base (WMDB). The WMDB was used until the beginning of fiscal year 1993 when a new data base table structure, the LWIS (Low-Level Waste Information System), was implemented. Records of waste disposals occurring prior to September 26, 1988, are recorded in the logbook data base and the WMDB. In 1996, the WMDB records were verified against the original shipping papers. Waste management data base records were selected as the only feasible data source for the shallow pits and trenches inventory.

The GCD and GCDT inventories have previously been estimated from original shipping records (Chu and Bernard, 1991). These data, as revised by Cochran (1997, personal communication), were used as the data source for GCD inventory.

The approach used to prepare the inventory estimates was to (1) retrieve a preliminary inventory from data base records, (2) estimate completeness of data base query results, (3) correct data base records for unreported or underreported radionuclides, and (4) correct data base records for unrecorded disposals and incomplete data base query results.

\section{A1.5.2 Data Quality and Completeness}

Waste disposal records generated from 1961 to 1992 have deficiencies. Major sources of uncertainty and bias in inventory data retrieved from Waste Management data bases and their treatment are described below.

- Uncertainty in the radionuclide activity estimated by the generator: Generator radionuclide characterization data are based on indirect methods such as process knowledge, gross radiation measurements, or material accountability data and are assumed to have significant uncertainty. Waste characterization methods that give results within a factor of ten of the true value are generally considered adequate, considering the difficulties of characterizing heterogenous waste forms (NRC, 1983; DOE, 1992). Shott et al. (1997) evaluated the potential uncertainty in the fission product activity in a simulated waste package characterized by gross radiation measurements and scaling factors. The activity estimates for several important fission and activation products all had ranges that spanned less than two orders of magnitude. Therefore, the uncertainty in waste characterization data was assumed to range from 0.1 to 10 times the reported value. The inventory uncertainty is assumed to be 100 percent correlated within the population of containers shipped by a single generator. Inventory uncertainty between generators is assumed to be uncorrelated. This is expected to be a conservative representation of the uncertainty in waste generator characterization data.

- Uncertainty in the completeness of data base records: Data base records may be biased because not all waste disposals were recorded. The classified waste inventory is especially 
likely to include this bias. This potential bias has been reduced by estimating the volume of waste not recorded in the data base and by increasing the inventory proportionally. This correction assumes that the missing waste has the same average concentration as the recorded waste. A bias may still exist because this correction may not adequately correct for missing inventory.

- Uncertainty in the completeness of generator waste characterization data: Generator waste characterization is recognized as being incomplete. This potential bias has been reduced by revising the inventory to include radionuclides suspected of being unreported or underreported. Bias may still exist because these revisions may not be complete or may not completely compensate for the bias.

- Uncertainty in the accuracy of data base records relative to the generator-reported characterization data: Data entry errors can occur. A verification of data base records against generator shipping records that occurred in 1996 is believed to have significantly reduced this problem. During preparation of this inventory, data base records containing unusually large inventories of important long-lived radionuclides were identified and compared with the original shipping records. The record was revised to be consistent with the original shipping record when discrepancies where found.

- Uncertainty in the completeness of data base query results: Data base queries are known to produce incomplete results because of structural problems in the WMDB used before 1993. This potential bias has been reduced by estimating the volume of waste not retrieved by data base queries and by increasing the inventory proportionally. This correction assumes that the missing waste has the same average concentration as the query results. A bias may still exist because this correction may not adequately correct for missing inventory.

Uncertainty in the inventory has been accounted for by assigning a conservative confidence interval to the generator characterization data and by applying corrections to account for biases caused by incomplete records and query results.

\section{A1.5.3 Estimated Completeness of Data Base Records and Query Results}

The completeness of data base records and query results was assessed by comparing the physical volume of waste in a trench with the data base query results. The total external volume of waste disposed in shallow pits and trenches at the Area 5 RWMS prior to September 26, 1988, was estimated from the physical dimensions and the operating history of the disposal units. External volume is defined as the volume displaced by the maximum dimensions of the waste package. Information on the operating histories of the disposal units was obtained from photographs and interviews (Farnham, 1997; personal communication). The total external volume of the waste was estimated as: 


$$
V_{p}=\sum_{t=1}^{n}\left[f_{d, t} L_{t, 88} W_{t}\left(D_{t}-X_{t}\right)\right]
$$

where

$\begin{array}{lll}\mathrm{V}_{\mathrm{p}} & = & \text { total waste external volume estimated from trench physical dimensions, } \\ \mathrm{f}_{\mathrm{d}, \mathrm{t}} & = & \mathrm{m}^{3} ; \\ \mathrm{L}_{\mathrm{t}, 88} & \text { facility design factor for disposal unit } \mathrm{t} \text {, dimensionless; } \\ \mathrm{W}_{\mathrm{t}} & = & \text { waste-filled length of disposal unit } \mathrm{t} \text { on September } 26,1988, \mathrm{~m} ; \\ \mathrm{D}_{\mathrm{t}} & = & \text { width of disposal unit } \mathrm{t}, \mathrm{m} ; \\ \mathrm{X}_{\mathrm{t}} & = & \text { depth of disposal unit } \mathrm{t} \text { measured from grade, } \mathrm{m} ; \text { and } \\ & \text { distance between grade and the top of the waste stack, } \mathrm{m} .\end{array}$

The parameters assumed for Equation A1.1 are listed in A1.6. The facility design factor is the fraction of the disposal unit volume that is occupied by external waste volume. The facility design factor was assumed to vary uniformly between 0.4 and 0.9 . The lower limit, 0.4 , was chosen to represent older disposal units where stacked waste collapsed as the operational closure cap was installed. The upper limit, 0.9 , represents the maximum thought routinely achievable. The P03U unit was reported to have an unusually high facility design factor because of the container design and stacking practices (Farnham, 1997; personal communication). The facility design factor for P03U was assumed to vary uniformly from 0.75 to 0.9 . The length, width, and depth of all disposal units closed before September 26, 1988, were assumed to be fixed. These data are from survey measurements that have minor uncertainties compared to other sources of uncertainty in the volume calculation.

The length of four disposal units (P03U, P04U, T04C, and T04C-1), partially filled on September 26, 1988, must be estimated. The length of the waste-filled trench was estimated from interviews (Farnham, 1997; personal communication). The filled length of P03U was assumed to vary uniformly from 36 to $46 \mathrm{~m}$ (120 to $150 \mathrm{ft})$. The filled length of P04U was assumed to vary uniformly from 24 to $36 \mathrm{~m}$ ( 80 to $120 \mathrm{ft}$ ). The filled length of T04C and T04C-1, combined, was assumed to vary uniformly from 225 to $265 \mathrm{~m}$ (740 to $870 \mathrm{ft}$ ).

The width and depth of all classified units were assumed to be 6.4 and $3.6 \mathrm{~m} \mathrm{(21} \mathrm{and} 12 \mathrm{ft})$, respectively. This corresponds to the dimensions of a three-sided observation screen, known as the white elephant, that is placed over classified waste for security purposes. All waste disposed in the classified trenches is stacked in the white elephant prior to covering.

The distance between grade and the top of waste was assumed to vary uniformly from 1.2 to $2 \mathrm{~m}$ $(3.9$ to $6.5 \mathrm{ft})$. A distance of $1.2 \mathrm{~m}(3.9 \mathrm{ft})$ between grade and the waste is the design specification and is considered the minimal distance. Waste is not always stacked to this height, and $2 \mathrm{~m}(6.5 \mathrm{ft})$ was assumed to be a reasonable upper limit. All other dimensions were fixed at the surveyed values in $s A 1.1$ and $A 1.2$. 


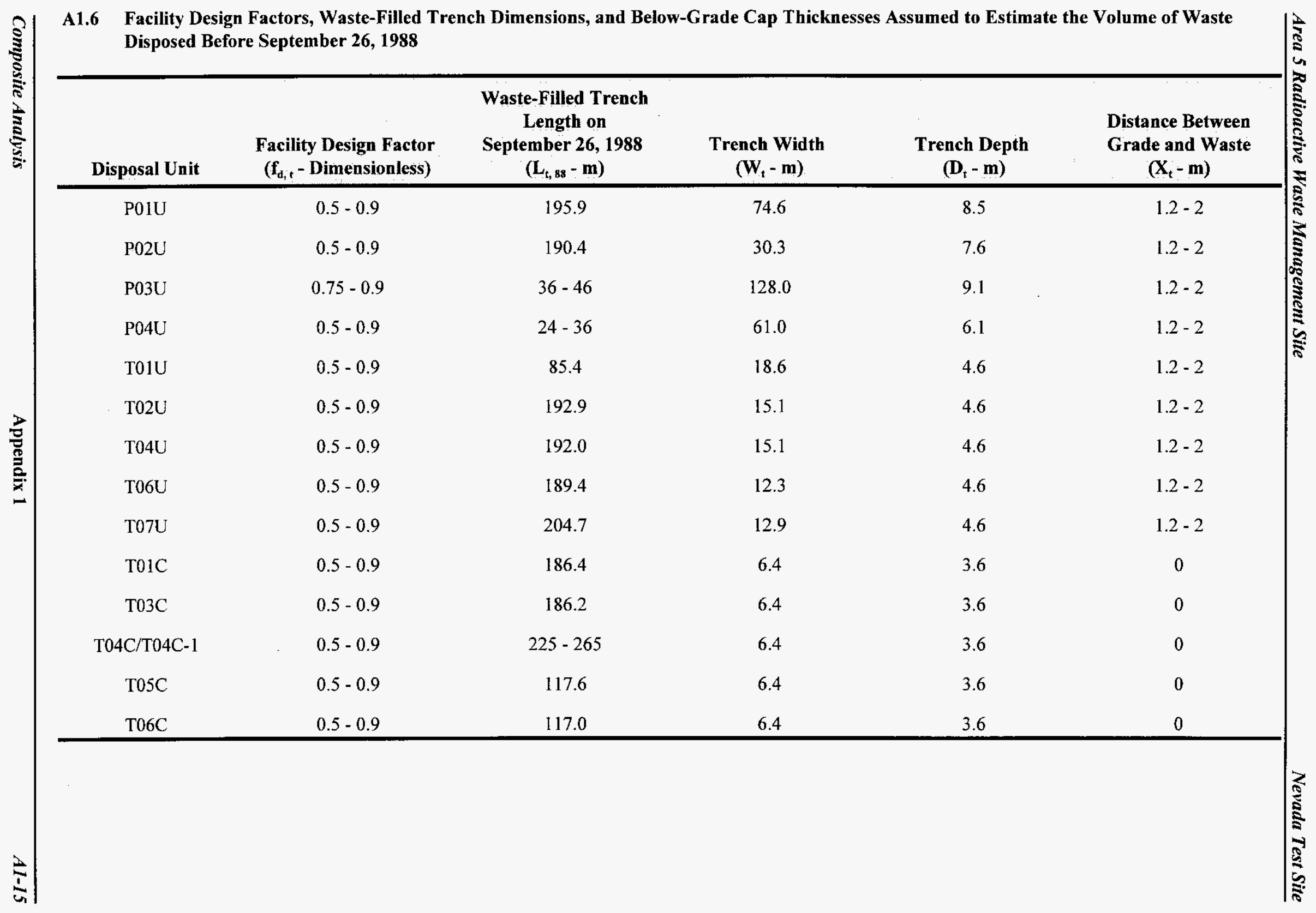


The total external waste volume was estimated by Monte Carlo simulation, using Equation A1.1. The estimated volume ranged from $1.2 \mathrm{e} 5$ to $2.1 \mathrm{e} 5$ cubic meters $\left[\mathrm{m}^{3}\right](4.2 \mathrm{e} 6$ to $7.4 \mathrm{e} 6$ cubic feet $\left.\left[\mathrm{ft}^{3}\right]\right)$. The most sensitive parameter, as measured by the Spearman rank correlation coefficient, was the facility design factor. The land area used for disposal was also estimated as the product of the length and width. The estimated land area used for disposal prior to September 26, 1988, was found to range from $4.4 \mathrm{e} 4$ to $4.6 \mathrm{e} 4 \mathrm{~m}^{2}\left(4.7 \mathrm{e} 5\right.$ to $\left.4.9 \mathrm{e} 5 \mathrm{ft}^{2}\right)$.

The total external volume disposed was obtained from the Waste Management data bases. The data obtained from the data bases was the total external volume of waste in disposal units operated prior to September 26, 1988. Again, four disposal units (P03U, P04U, T04C, and T04C-1) contain waste disposed after this date, and the volume must be corrected. The external volumes recorded in the data base were corrected as:

$$
V_{d b}=\sum_{t=1}^{n}\left(\frac{L_{t, 88}}{L_{t}} V_{d b, t}\right)
$$

where

$\mathrm{V}_{\mathrm{db}}=$ total external volume, estimated from data base records, disposed before September 26, 1988, $\mathrm{m}^{3}$;

$\mathrm{L}_{\mathrm{t}} \quad=$ length of disposal unit $\mathrm{t}, \mathrm{m}$; and

$\mathrm{V}_{\mathrm{db}, \mathrm{t}}=$ total external volume retrieved from the data base for disposal unit $\mathrm{t}, \mathrm{m}^{3}$.

The total external volume recorded in data base records appears in Table A1.7. The external volume was assumed to be fixed. The $\mathrm{L}_{t, 88} / \mathrm{L}_{\mathrm{t}}$ weighting factor is assumed to be 1.0 for waste with an unknown disposal location. These wastes were likely disposed early in the Area 5 RWMS operating history and are likely to be in units closed before September 26, 1988. Correcting the external volume data for the date of disposal using Equation A1.2 yields a data base-derived total external volume estimate that ranges from $1.35 \mathrm{e} 5$ to $1.44 \mathrm{e} 5 \mathrm{~m}^{3}(4.8 \mathrm{e} 6$ to $\left.5.1 \mathrm{e} 6 \mathrm{ft}^{3}\right)$.

Comparison of the physical volume of the trenches with the volume recorded in the data base may provide an indication of the completeness of data base records and query results. The ratio of the data base estimated volume to the volume estimated from trench dimensions $\left(\mathrm{V}_{\mathrm{db}} / \mathrm{V}_{\mathrm{p}}\right)$ ranges from 0.67 to 1.2 . This indicates that the query results for the total external volume may include from 67 to 115 percent of the waste volume disposed before September 26,1988 . The $\mathrm{V}_{\mathrm{p}} / \mathrm{V}_{\mathrm{db}}$ ratio was used to correct data base records for missing inventory. The ratio was fit to a triangular distribution with a minimum of 0.885 , mode of 1.25 , and maximum of 1.50 . 
Table A1.7 Total External Volume and Activity Retrieved From Queries of Waste Management Data Bases. Results for P03U, P04U, T04C, and T04C-1 include waste disposed after September 26, 1988.

\begin{tabular}{ccc}
\hline Disposal Unit & Total External Volume $\left(\mathbf{m}^{3}\right)$ & Total Undecayed Activity $(\mathbf{C i})$ \\
\hline T01U & $8.6 \mathrm{e} 2$ & $2.0 \mathrm{e} 3$ \\
T06U & $4.7 \mathrm{e} 3$ & $1.5 \mathrm{e} 4$ \\
T07U & $7.5 \mathrm{e} 2$ & $4.1 \mathrm{e}-1$ \\
T04U & $8.3 \mathrm{e} 2$ & $6.1 \mathrm{e} 2$ \\
T02U & $6.3 \mathrm{e} 3$ & $3.1 \mathrm{e} 3$ \\
P01U & $2.0 \mathrm{e}-1$ & $0.0 \mathrm{e} 0$ \\
P02U & $1.7 \mathrm{e} 4$ & $7.0 \mathrm{e} 4$ \\
P03U & $3.3 \mathrm{e} 4$ & $5.5 \mathrm{e} 4$ \\
P04U & $6.8 \mathrm{e} 4$ & $1.1 \mathrm{e} 5$ \\
T01C & $3.0 \mathrm{e} 2$ & $8.9 \mathrm{e} 1$ \\
T03C & $0.0 \mathrm{e} 0$ & $0.0 \mathrm{e} 0$ \\
T05C & $0.0 \mathrm{e} 0$ & $0.0 \mathrm{e} 0$ \\
T06C & $0.0 \mathrm{e} 0$ & $0.0 \mathrm{e} 0$ \\
T04C, T04C-1 & $2.1 \mathrm{e} 3$ & $1.7 \mathrm{e} 3$ \\
Unknown & $7.1 \mathrm{e} 4$ & $6.9 \mathrm{e} 6$ \\
\hline Total & $\mathbf{2 . 0 e 5}$ & $7.2 \mathrm{e} 6$ \\
\hline
\end{tabular}

\section{A1.5.4 Estimation of Radionuclide Inventory Disposed Before September 26, 1988, in the Shallow Pits and Trenches}

The radionuclide inventory of waste disposed before September 26,1988 , is poorly known. Accuracy and completeness of generator waste characterization data are two potentially important sources of uncertainty. Waste disposal records from this period often report only the gross activity in the waste. When the activities of specific radionuclides are reported, there is often reason to suspect that some radionuclides important to long-term performance have not been reported. The other important source of uncertainty is the completeness of data base records and query results. It is suspected that data base records do not include all disposals that occurred. In addition, queries of the WMDB that sum activity by radionuclide and by generator are suspected of being incomplete, because of problems with the data base structure. 
The approach used to estimate the radionuclide composition of the waste was to query the data base to obtain the activity of individual radionuclides by shipment. Four data sources were combined to estimate the inventory. These four data sources were a query of the Waste Management logbook data base, a query of the WMDB in units of Curies, a query of the WMDB in units of grams, and the inventory of TRU waste disposed in P04C-1 (Price, 1992; memorandum).

These data were screened and revised to remove obvious errors and nuclides unimportant to long-term site performance. Some radionuclide entries were for unknown radionuclides. If an obvious radionuclide could be identified from the entry, the record was corrected. If the entry was ambiguous, the record was deleted. The inventory of deleted entries is extremely small and unlikely to have any impact on the results. All radionuclides with half-lives less than five years, that do not decay to a long-lived progeny were deleted. Radionuclides with a half-life less than five years that decay to a radioactive progeny were deleted only if the progeny's half-life was very much greater than the parents' half-lives. These nuclides will produce negligible amounts of their progeny and can be neglected.

The radionuclide inventory was estimated by summing the radionuclide activity by shipment and generator. Generator totals were corrected for unreported or underreported radionuclides. The grand total for each radionuclide was corrected for incomplete disposal records and data base query results based on the ratio of the physical volume of the trenches and the waste volume recorded in the data base. The inventory of each individual radionuclide was calculated as:

$$
A_{j}=\left(\frac{V_{p}}{V_{d b}}\right) \sum_{k=1}^{n}\left[\sum_{s=1}^{m} A_{j, s, k}+\sum_{r=1}^{o}\left(f_{j, r, k} \sum_{s=1}^{m} A_{r, s, k}\right)\right]
$$

where

$$
\begin{aligned}
& \mathrm{A}_{\mathrm{j}} \quad=\quad \text { activity of radionuclide } \mathrm{j}, \mathrm{Ci} \text {; } \\
& \mathrm{V}_{\mathrm{p}}=\text { volume of waste estimated from physical dimensions of trenches, } \mathrm{m}^{3} \text {; } \\
& \mathrm{V}_{\mathrm{db}}=\text { volume of waste recorded in data base, } \mathrm{m}^{3} \text {; } \\
& \mathrm{A}_{\mathrm{j}, \mathrm{s}, \mathrm{k}}=\text { activity of radionuclide } \mathrm{j} \text { in shipment } \mathrm{s} \text { from generator } \mathrm{k}, \mathrm{Ci} \text {; } \\
& \mathrm{f}_{\mathrm{j}, \mathrm{r}, \mathrm{k}}=\text { scaling factor for radionuclide } \mathrm{j} \text { based on reference radionuclide } \mathrm{r} \text { for } \\
& \text { generator } \mathrm{k} \text {, dimensionless; and } \\
& \mathrm{A}_{\mathrm{r}, \mathrm{s}, \mathrm{k}}=\quad \text { activity of reference radionuclide } \mathrm{r} \text { in shipment } \mathrm{s} \text { from generator } \mathrm{k}, \mathrm{Ci} \text {. }
\end{aligned}
$$

Shipment activities, $A_{j, s, k}$ and $A_{r, s, k}$, were assumed to be loguniformly distributed, with lower and upper limits of 0.1 and 10 times the generator reported values. Errors within generator shipments were assumed to correlate with a correlation coefficient of 1.0. Consequently, uncertainty in the total radionuclide activity shipped by a generator is assumed to be loguniformly distributed with lower and upper limits of 0.1 and 10 times the sum. Errors were assumed to be independent between generators. 


\section{A1.5.5 Scaling Factors Used to Revise Radionuclide Composition}

The activities of radionuclides suspected to be present in waste, but not reported by the generator, are estimated below using scaling factors. In many instances, the data necessary to estimate these scaling factors are not available. Conservative, yet reasonable, estimates have been made.

\section{A1.5.5.1 Scaling Factors for Mixed Fission Products and Activation Products}

The activity in some waste shipments was recorded as gross activity or as mixed fission products (MFP). The majority of this activity was not assigned to any generator in the queries prepared, so its source is unknown. The gross activity was assumed to be fission and activation products. The two major sources of fission and activation products disposed at the Area 5 RWMS are believed to be debris from nuclear weapons testing conducted at the NTS and debris and equipment from the Nuclear Reactor Development Station, also on the NTS.

The activity of individual fission and activation products was estimated using a scaling factor calculated as the activity fraction of the estimated radionuclide divided by the activity fraction of the reference radionuclide for a radionuclide mixture representative of NTS underground nuclear testing debris. The mixed fission and activation product waste streams are assumed to be estimated by exposure measurements. Therefore, the appropriate reference radionuclides would be all nuclides contributing to the gamma exposure. For simplicity, the reference radionuclide is assumed to be ${ }^{137} \mathrm{Cs}$ and its progeny. This is an extremely conservative assumption for fresh fission products and becomes more reasonable as the age of the waste increases (Shott et al., 1997). The radionuclide activity fractions were derived from the inventories estimated for the underground testing areas on Pahute Mesa and not on Pahute Mesa (DOE, 1996b). The scaling factor was estimated as:

$$
f_{j, r, k}=\frac{y_{j}}{y_{r}}
$$

where

$$
\begin{aligned}
& y_{\mathrm{j}}=\text { assumed activity fraction of radionuclide } \mathrm{j} \text {, dimensionless; and } \\
& \mathrm{y}_{\mathrm{r}}=\text { assumed activity fraction of the reference radionuclide }\left({ }^{137} \mathrm{Cs}\right) \text {, dimensionless. }
\end{aligned}
$$

The activity fractions were assumed to be lognormally distributed with mean and standard deviation calculated from the data for the underground testing inventory on Pahute Mesa and not on Pahute Mesa (Table A1.8). 
Table A1.8 Mean and Standard Deviation Assumed for Activity Fractions of Radionuclides in Gross Activity or Mixed Fission Products Disposed in the Shallow Pits and Trenches at the Area 5 RWMS Before September 26, 1988. Derived from the estimated underground testing inventory on Pahute Mesa and not on Pahute Mesa (DOE, 1996b).

\begin{tabular}{|c|c|c|c|c|c|}
\hline Nuclide & $\begin{array}{c}\text { Mean Activity } \\
\text { Fraction }\end{array}$ & $\begin{array}{l}\text { Standard } \\
\text { Deviation }\end{array}$ & Nuclide & $\begin{array}{c}\text { Mean Activity } \\
\text { Fraction }\end{array}$ & $\begin{array}{l}\text { Standard } \\
\text { Deviation }\end{array}$ \\
\hline${ }^{3} \mathrm{H}$ & $8.94 \mathrm{e}-1$ & $1.70 \mathrm{e}-2$ & ${ }^{151} \mathrm{Sm}$ & $1.81 \mathrm{e}-3$ & $2.55 \mathrm{e}-4$ \\
\hline${ }^{14} \mathrm{C}$ & $1.59 \mathrm{e}-5$ & $1.24 \mathrm{e}-5$ & ${ }^{150} \mathrm{Eu}$ & $8.48 \mathrm{e}-6$ & $8.38 \mathrm{e}-6$ \\
\hline${ }^{26} \mathrm{Al}$ & $6.58 \mathrm{e}-10$ & $7.67 \mathrm{e}-10$ & ${ }^{152} \mathrm{Eu}$ & $1.13 \mathrm{e}-3$ & $1.00 \mathrm{e}-3$ \\
\hline${ }^{36} \mathrm{Cl}$ & $4.65 e-6$ & $2.65 \mathrm{e}-6$ & ${ }^{154} \mathrm{Eu}$ & $7.96 \mathrm{e}-4$ & $8.41 \mathrm{e}-4$ \\
\hline${ }^{39} \mathrm{Ar}$ & $2.58 \mathrm{e}-5$ & $2.55 \mathrm{e}-6$ & ${ }^{166} \mathrm{Ho}$ & $2.98 \mathrm{e}-10$ & $7.57 \mathrm{e}-11$ \\
\hline${ }^{40} \mathrm{~K}$ & $6.59 \mathrm{e}-6$ & $7.21 \mathrm{e}-7$ & ${ }^{232} \mathrm{Th}$ & $3.84 \mathrm{e}-10$ & $5.27 \mathrm{e}-10$ \\
\hline${ }^{41} \mathrm{Ca}$ & $3.51 \mathrm{e}-5$ & $1.94 \mathrm{e}-5$ & ${ }^{232} \mathrm{U}$ & $6.90 \mathrm{e}-6$ & $5.09 \mathrm{e}-6$ \\
\hline${ }^{59} \mathrm{Ni}$ & $8.69 \mathrm{e}-7$ & $4.97 \mathrm{e}-7$ & ${ }^{233} \mathrm{U}$ & $3.27 \mathrm{e}-6$ & $1.48 \mathrm{e}-6$ \\
\hline${ }^{63} \mathrm{Ni}$ & $1.01 \mathrm{e}-4$ & $6.60 \mathrm{e}-5$ & ${ }^{234} \mathrm{U}$ & $2.82 \mathrm{e}-6$ & $1.74 \mathrm{e}-6$ \\
\hline${ }^{85} \mathrm{Kr}$ & $3.35 \mathrm{e}-3$ & $2.62 \mathrm{e}-4$ & ${ }^{235} \mathrm{U}$ & $6.53 e-8$ & $6.19 \mathrm{e}-8$ \\
\hline${ }^{90} \mathrm{Sr}$ & $4.29 \mathrm{e}-2$ & $5.09 \mathrm{e}-3$ & ${ }^{236} \mathrm{U}$ & $7.98 \mathrm{e}-8$ & $2.62 \mathrm{e}-8$ \\
\hline${ }^{93} \mathrm{Zr}$ & $1.49 \mathrm{e}-6$ & $2.26 \mathrm{e}-7$ & ${ }^{238} \mathrm{U}$ & $1.15 \mathrm{e}-7$ & $1.22 \mathrm{e}-7$ \\
\hline${ }^{93 \mathrm{~m}} \mathrm{Nb}$ & $1.40 \mathrm{e}-4$ & $5.91 \mathrm{e}-5$ & ${ }^{237} \mathrm{~Np}$ & $3.95 \mathrm{e}-7$ & $1.11 \mathrm{e}-7$ \\
\hline${ }^{94} \mathrm{Nb}$ & $3.92 \mathrm{e}-6$ & $2.38 \mathrm{e}-6$ & ${ }^{238} \mathrm{Pu}$ & $2.16 \mathrm{e}-4$ & $1.74 \mathrm{e}-4$ \\
\hline${ }^{99} \mathrm{Tc}$ & $9.58 \mathrm{e}-6$ & $1.07 \mathrm{e}-5$ & ${ }^{239} \mathrm{Pu}$ & $5.39 \mathrm{e}-4$ & $4.08 \mathrm{e}-4$ \\
\hline${ }^{107} \mathrm{Pd}$ & $4.20 \mathrm{e}-8$ & $4.95 \mathrm{e}-8$ & ${ }^{240} \mathrm{Pu}$ & $1.47 \mathrm{e}-4$ & $9.38 \mathrm{e}-5$ \\
\hline${ }^{113 \mathrm{~m}} \mathrm{Cd}$ & $3.30 \mathrm{e}-5$ & $3.25 \mathrm{e}-5$ & ${ }^{241} \mathrm{Pu}$ & $2.07 e-3$ & $1.27 \mathrm{e}-3$ \\
\hline${ }^{121 m} \mathrm{Sn}$ & $1.20 \mathrm{e}-4$ & $1.25 \mathrm{e}-4$ & ${ }^{242} \mathrm{Pu}$ & $8.68 \mathrm{e}-8$ & $6.12 \mathrm{e}-8$ \\
\hline${ }^{126} \mathrm{Sn}$ & $1.41 \mathrm{e}-6$ & $1.46 e-6$ & ${ }^{241} \mathrm{Am}$ & $1.28 \mathrm{e}-4$ & $9.58 \mathrm{e}-5$ \\
\hline${ }^{129} \mathrm{I}$ & $2.89 \mathrm{e}-8$ & $3.17 \mathrm{e}-8$ & ${ }^{243} \mathrm{Am}$ & $5.03 \mathrm{e}-8$ & $6.79 \mathrm{e}-8$ \\
\hline${ }^{335} \mathrm{Cs}$ & $9.90 \mathrm{e}-7$ & $1.12 \mathrm{e}-6$ & ${ }^{244} \mathrm{Cm}$ & $5.30 \mathrm{e}-5$ & $2.05 \mathrm{e}-5$ \\
\hline${ }^{137} \mathrm{Cs}$ & $4.74 \mathrm{e}-2$ & $5.25 \mathrm{e}-2$ & & & \\
\hline
\end{tabular}




\section{A1 5.5.2 Scaling Factors for Fission Products and Transuranic Nuclides in Uranium}

Fission products and transuranic radionuclides enter DOE uranium feed material when irradiated uranium is recycled. The most significant contaminants are reported to be ${ }^{99} \mathrm{Tc},{ }^{232} \mathrm{U},{ }^{237} \mathrm{~Np},{ }^{238} \mathrm{Pu}$ and ${ }^{239} \mathrm{Pu}$ (Rich et al., 1988; Fernald Environmental Management Program [FEMP], 1996). These contaminants may become fractionated at several stages during the conversion and enrichment process. The variable presence of recycled uranium in the feed material and the potential for fractionation make the scaling factors for these nuclides quite variable and uncertain.

The FEMP is the major source of uranium disposed at NTS. Therefore, the data used to estimate fission products and transuranics in uranium were based on information provided by the FEMP (FEMP, 1996). The only long-lived fission products in uranium waste streams reported by FEMP (1996) are ${ }^{90} \mathrm{Sr}$ and ${ }^{99} \mathrm{Tc}$. Long-lived transuranic radionuclides in FEMP uranium waste streams include ${ }^{237} \mathrm{~Np}$, ${ }^{239} \mathrm{Pu}$, and ${ }^{241} \mathrm{Am}$. Scaling factors for other plutonium isotopes were estimated from the reported ${ }^{239} \mathrm{Pu}$ activity assuming a scrap plutonium composition characteristic of the American National Standards Institute ([ANSI], 1987) PU-51 scrap code.

Fission product and transuranic radionuclide scaling factors were estimated for three reference radionuclides, ${ }^{235} \mathrm{U}$ in 1 to 3 percent enriched uranium, ${ }^{235} \mathrm{U}$ in 93 to 96 percent enriched uranium, and ${ }^{238} \mathrm{U}$ (Table A1.9). The scaling factors multiplied by the ${ }^{235} \mathrm{U}$ activity (low and full enrichment) were based on the estimated composition of the FEMP low-grade enriched uranium waste stream. The factors multiplied by the ${ }^{238} \mathrm{U}$ activities were based on the FEMP low-grade depleted uranium waste stream. The scaling factors are assumed to be loguniformly distributed, with lower and upper limits equal to 0.1 and 10 times, respectively, of the generator reported value.

\section{A1 1.5.5 Scaling Factors for Uranium Isotopes in Depleted and Enriched Uranium}

The reported isotopic composition of uranium waste streams disposed in the past are incomplete. Disposal records for uranium waste streams usually list one isotope, ${ }^{235} \mathrm{U}$ or ${ }^{238} \mathrm{U}$, or occasionally list a code such as DU or D-238. An isotopic composition was assigned to each generator based on the isotope reported and the generator's processes. All activity listed as ${ }^{238} \mathrm{U}$ was assumed to represent a depleted uranium waste stream. All activity listed as ${ }^{235} \mathrm{U}$ was assumed to be enriched uranium. Enriched uranium from the FEMP was assumed to be 1 to 3 percent enriched uranium, and all other generators were conservatively assumed to be 93 to 96 percent enriched uranium. Reasonable ranges of isotopic composition as a function of enrichment were estimated from the data of Rich et al. (1988) (Table A1.9). 
Table A1.9 Assumed Scaling Factors for Unreported Radionuclides in Uranium. The reference radionuclide is the reported radionuclide used to the scale the activity of the unreported radionuclides.

\begin{tabular}{|c|c|c|c|}
\hline \multirow[b]{2}{*}{$\begin{array}{l}\text { Unreported } \\
\text { Nuclides }\end{array}$} & \multicolumn{3}{|c|}{ Reference Radionuclide } \\
\hline & ${ }^{238} \mathbf{U}^{1}$ & $\left(1-3 \%\right.$ Enrichment $\left.{ }^{2}\right)$ & (93 to $96 \%$ Enrichment $\left.{ }^{3}\right)$ \\
\hline${ }^{90} \mathrm{Sr}$ & Loguniform: $3 \mathrm{e}-4$ - 3e-2 & Loguniform: $2 \mathrm{e}-3$ - 2e-1 & Loguniform: $2 \mathrm{e}-3-2 \mathrm{e}-1$ \\
\hline${ }^{99} \mathrm{Tc}$ & Loguniform: $7 \mathrm{e}-3-7 \mathrm{e}-1$ & Loguniform: $4 \mathrm{e}-2-4 \mathrm{e}-0$ & Loguniform: $4 \mathrm{e}-2-4 \mathrm{e}-0$ \\
\hline${ }^{234} \mathrm{U}$ & Uniform: $0.1-0.4$ & Uniform: $12-21$ & Uniform: $30-32$ \\
\hline${ }^{235} \mathrm{U}$ & Uniform: $0.01-0.03$ & & \\
\hline${ }^{236} \mathrm{U}$ & & Fixed: $2 \mathrm{e} 0$ & Fixed: $1 \mathrm{e}-1$ \\
\hline${ }^{238} \mathrm{U}$ & & Uniform: $4.5-15$ & Fixed: $9 \mathrm{e}-3$ \\
\hline${ }^{237} \mathrm{~Np}$ & Fixed: $2 \mathrm{e}-3$ & Fixed: $9 \mathrm{e}-3$ & Fixed: $9 \mathrm{e}-3$ \\
\hline${ }^{238} \mathrm{Pu}$ & $\mathrm{f}_{\mathrm{Pu} 238, \text { Pu239, }} \mathrm{f}_{\mathrm{Pu} 239, \mathrm{U} 238, \mathrm{k}^{4}}$ & $\mathrm{f}_{\mathrm{Pu} 238, \mathrm{Pu} 239, \mathrm{k}} \mathrm{f}_{\mathrm{Pu} 239, \mathrm{U} 235, \mathrm{FEMP}}$ & $f_{P u 238, \text { Pu239, }} f_{P u 239,}$ U235, Not FEMP \\
\hline${ }^{239} \mathrm{Pu}$ & Loguniform: $2 \mathrm{e}-4-2 \mathrm{e}-2$ & Loguniform: $2 \mathrm{e}-3-2 \mathrm{e}-1$ & Loguniform: $2 \mathrm{e}-3-2 \mathrm{e}-1$ \\
\hline${ }^{240} \mathrm{Pu}$ & $\mathrm{f}_{\mathrm{Pu} 240, \text { Pu239, }} \mathrm{f}_{\mathrm{Pu} 239, \mathrm{U} 238, \mathrm{k}}$ & $f_{P u 240, \text { Pu239, } k} f_{P u 239,}$ U235, FEMP & $\mathrm{f}_{\mathrm{Pu} 240, \mathrm{Pu} 239, \mathrm{k}} \mathrm{f}_{\mathrm{Pu} 239, \mathrm{U} 235, \text { Not FEMP }}$ \\
\hline${ }^{24 !} \mathrm{Pu}$ & $f_{P u 241, P u 239, k} f_{P u 239, ~ U 238, k}$ & $\mathrm{f}_{\mathrm{Pu} 241, \mathrm{Pu} 239, \mathrm{k}} \mathrm{f}_{\mathrm{Pu} 239, \mathrm{U} 235, \mathrm{FEMP}}$ & 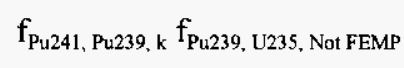 \\
\hline${ }^{241} \mathrm{Am}$ & $f_{\text {Am241, Pu239, } k} f_{\text {Pu239, U238, } k}$ & $f_{\text {Am241, Pu239, } k} f_{\text {Pu239, U235, FEMP }}$ & $f_{A m 241, \text { Pu239, } k} f_{\text {Pu239, U235, Not FEMI }}$ \\
\hline
\end{tabular}

'The scaling factors are based on a depleted uranium waste stream from the FEMP.

${ }^{2}$ The fission product scaling factors are for a 1 percent enriched uranium waste stream based on the low-grade residues enriched uranium waste stream from the FEMP. Uranium scaling factors are for a 1 to 3 percent enriched uranium waste stream.

${ }^{3}$ The scaling factors are for a 93 to 96 percent enriched uranium waste stream. The fission product and transuranic radionuclide composition is based on the low-grade residues enriched uranium waste stream from the FEMP.

${ }^{4} f_{j, t}, k$ scaling factor for radionuclide $j$, reference radionuclide $r$, and generator $k$.

\section{A1 5.5.4 Scaling Factors for Transuranic Nuclides in Scrap Plutonium}

The radionuclide composition of plutonium waste streams disposed in the past is also incomplete. Plutonium waste streams often list only ${ }^{239} \mathrm{Pu}$ or an ANSI scrap code, when several transuranic radionuclides are expected. The scaling factor was calculated as a ratio of specific activities based on mass abundances reported for various plutonium mixtures.

The specific activity of each nuclide in $1 \mathrm{~g}$ of $\mathrm{Pu}$ scrap is calculated as:

$$
q_{j}=1 \mathrm{~g} \frac{k_{j} \lambda_{j} D F_{j}}{M_{j}} \frac{6.023 \text { e23atoms }}{\text { mole }} \frac{1 C i}{3.7 e 10 B q} \frac{1 y r}{365.25 \text { days }} \frac{1 d a y}{24 h r s} \frac{1 \mathrm{hr}}{60 \mathrm{~min}} \frac{1 \mathrm{~min}}{60 \mathrm{sec}}
$$


where

$\mathrm{q}_{\mathrm{j}} \quad=$ activity of nuclide $\mathrm{j}$ in $1 \mathrm{~g}$ of ANSI scrap code PU-5X, Ci;

$\mathrm{k}_{\mathrm{j}} \quad=$ mass abundance of nuclide $\mathrm{j}$, dimensionless;

$\lambda_{\mathrm{j}} \quad=$ radiological decay constant, $\left(\mathrm{yr}^{-1}\right)$;

$\mathrm{DF}_{\mathrm{j}} \quad=$ decay factor for radionuclide $\mathrm{j}$, dimensionless;

$\mathrm{M}_{\mathrm{j}} \quad=$ atomic mass of nuclide $\mathrm{j}, \mathrm{g} /$ mole; and

$$
D F_{j}=\left\{\begin{array}{c}
e^{-\lambda_{j} t} \text { for } j=P u-238, P u-239, P u-240, P u-242, P u-241 \\
\frac{\lambda_{j+1}}{\lambda_{j+1}-\lambda_{j}}\left(e^{-\lambda_{j} t}-e^{-\lambda_{j+1} t}\right) \text { for } j=P u-241 \text { and } j+1=A m-241
\end{array}\right.
$$

The mass abundance of ${ }^{238} \mathrm{Pu},{ }^{241} \mathrm{Pu}$, and ${ }^{242} \mathrm{Pu}$ are fixed at mean values reported for Rocky Flats waste plutonium (Shott et al., 1997) (Table A1.10). The mass abundance of ${ }^{240} \mathrm{Pu}$ was assumed to vary uniformly between the limits for the given ANSI scrap code (ANSI, 1987). The mass fraction of ${ }^{241} \mathrm{Am}$ was assumed to be zero initially. The mass fraction of ${ }^{239} \mathrm{Pu}$ was calculated as one less the sum of all other nuclide mass abundances. The elapsed time between production and disposal was assumed to vary uniformly from 5 to 43 years.

Table A1.10 Assumed Mass Abundance of Transuranic Radionuclides in Scrap Plutonium

\begin{tabular}{ccccc}
\hline & & Mass Abundance at Time of Production & \\
\cline { 2 - 5 } Nuclide & ${ }^{239} \mathrm{Pu}$ & PU-51 & PU-52 & PU-57 \\
\hline${ }^{238} \mathrm{Pu}$ & Fixed: $1 \mathrm{e}-4$ & Fixed: $1 \mathrm{e}-4$ & Fixed: $1 \mathrm{e}-4$ & Fixed: $1 \mathrm{e}-4$ \\
${ }^{239} \mathrm{Pu}$ & Fixed: 0 & $1-\sum \mathrm{k}_{\mathrm{j}}$ & $1-\sum \mathrm{k}_{\mathrm{j}}$ & $1-\sum \mathrm{k}_{\mathrm{j}}$ \\
${ }^{240} \mathrm{Pu}$ & Uniform: $0.02-0.04$ & Uniform: $0.02-0.04$ & Uniform: $0.04-0.07$ & Uniform: $0.20-0.24$ \\
${ }^{241} \mathrm{Pu}$ & Fixed: $3.6 \mathrm{e}-3$ & Fixed: $3.6 \mathrm{e}-3$ & Fixed: $3.6 \mathrm{e}-3$ & Fixed: $3.6 \mathrm{e}-3$ \\
${ }^{242} \mathrm{Pu}$ & Fixed: $3 \mathrm{e}-4$ & Fixed: $3 \mathrm{e}-4$ & Fixed: $3 \mathrm{e}-4$ & Fixed: $3 \mathrm{e}-4$ \\
${ }^{241} \mathrm{Am}$ & Fixed: 0 & Fixed: 0 & Fixed: 0 & Fixed: 0 \\
\hline
\end{tabular}


The scaling factors for $\mathrm{Pu}$ scrap codes were calculated using the specific activities as:

$$
f_{j, r, k}=\frac{q_{j}}{\sum_{m=1}^{n} q_{m}}
$$

The scaling factors for ${ }^{239} \mathrm{Pu}$ were calculated as:

$$
f_{j, r, k}=\left\{\begin{array}{c}
0 \text { for } j=P u-239 \\
\frac{q_{j}}{q_{P u 239}} \text { for } j \neq P u-239
\end{array}\right.
$$

\section{A1.5.6 Estimated Inventory for the Area 5 RWMS Shallow Pits and Trenches}

The radionuclide inventory disposed before September 26, 1988, was estimated deterministically using Equation A1.3 for all radionuclides (Table A1.11). A reduced list of radionuclides was developed from a conservative screening analysis described in Chapter 4. Radionuclides meeting the screening calculation were carried forward for the total inventory estimate. The mean and standard deviation of individual radionuclides meeting the screening criteria were estimated by performing 10,000 Monte Carlo realizations of Equation A1.3 (Table A1.12). The distributions of nuclide activities were skewed positively and are assumed to be lognormally distributed. The mean radionuclide inventories were decayed to closure in 2028 using the ORIGEN2.1 computer code (Croft, 1982) (Table A1.12).

The total inventory at closure was estimated by combining the inventory disposed before September 26, 1988, as estimated above, and the inventory estimated in the Area 5 PA (Shott et al., 1997) (Table A1.12). The Area 5 PA inventory is estimated for the year 2028 and includes estimates of wastes disposed from 1994 through 2028. The Area 5 PA inventory values were assumed to be the median of the distribution. The Area $5 \mathrm{~Pa}$ inventory was assumed to be lognormally distributed with a 95 th percentile equal to 10 times the median. The uncertainty of the total inventory was estimated by Monte Carlo simulation of the sum of the two inventories. At closure, the long-lived component of the inventory consists predominantly of ${ }^{3} \mathrm{H},{ }^{137} \mathrm{Cs}$, and ${ }^{90} \mathrm{Sr}$. Beyond 200 to 300 years, the inventory is predominantly uranium isotopes, ${ }^{239} \mathrm{Pu}$, and ${ }^{99} \mathrm{Tc}$ (Figure A1.2). 
Table A1.11 Deterministic Estimate of Inventory Disposed at the Area 5 RWMS in the Shallow Pits and Trenches Before September $26,1988$. Volume corrected total represents inventory corrected for waste volume that may not be recorded in Waste Management data bases. Activities are reported as of 1988 .

\begin{tabular}{|c|c|c|c|c|c|c|c|c|c|}
\hline Nuclide & $\begin{array}{l}\text { Data Base } \\
\text { Total (Ci) }\end{array}$ & $\begin{array}{l}\text { Revisions } \\
\text { Total }(\mathrm{Ci})\end{array}$ & Total (Ci) & $\begin{array}{l}\text { Volume } \\
\text { Corrected } \\
\text { Total (Ci) }\end{array}$ & Nuclide & $\begin{array}{l}\text { Data Base } \\
\text { Total (Ci) }\end{array}$ & $\begin{array}{l}\text { Revisions } \\
\text { Total (Ci) }\end{array}$ & Total (Ci) & $\begin{array}{l}\text { Volume } \\
\text { Corrected } \\
\text { Total (Ci) }\end{array}$ \\
\hline MFP & $3.4 \mathrm{e}+03$ & $-3.4 \mathrm{e}+03$ & $0.0 \mathrm{e}+00$ & $0.0 \mathrm{e}+00$ & ${ }^{207} \mathrm{Bi}$ & $2.5 \mathrm{e}-05$ & $0.0 \mathrm{e}+00$ & $2.5 \mathrm{e}-05$ & $3.0 \mathrm{e}-05$ \\
\hline${ }^{3} \mathrm{H}$ & $6.4 \mathrm{e}+06$ & $5.9 \mathrm{e}+04$ & $6.4 \mathrm{e}+06$ & $7.9 \mathrm{e}+06$ & ${ }^{226} \mathrm{Ra}$ & $1.8 \mathrm{e}+01$ & $0.0 \mathrm{e}+00$ & $1.8 \mathrm{e}+01$ & $2.3 \mathrm{e}+01$ \\
\hline${ }^{14} \mathrm{C}$ & $3.8 \mathrm{e}-01$ & $1.0 \mathrm{e}+00$ & $1.4 \mathrm{e}+00$ & $1.8 \mathrm{e}+00$ & ${ }^{227} \mathrm{Ac}$ & $2.8 \mathrm{e}-01$ & $0.0 \mathrm{e}+00$ & $2.8 \mathrm{e}-01$ & $3.4 \mathrm{e}-01$ \\
\hline${ }^{26} \mathrm{Al}$ & $0.0 \mathrm{e}+00$ & $4.3 \mathrm{e}-05$ & $4.3 \mathrm{e}-05$ & $5.3 \mathrm{e}-05$ & ${ }^{228} \mathrm{Th}$ & $1.8 \mathrm{e}-02$ & $0.0 \mathrm{e}+00$ & $1.8 \mathrm{e}-02$ & $2.2 \mathrm{e}-02$ \\
\hline${ }^{36} \mathrm{Cl}$ & $0.0 \mathrm{e}+00$ & $3.0 \mathrm{e}-01$ & $3.0 \mathrm{e}-01$ & $3.8 \mathrm{e}-01$ & ${ }^{229} \mathrm{Th}$ & $1.0 \mathrm{e}-09$ & $0.0 \mathrm{e}+00$ & $1.0 \mathrm{e}-09$ & $1.2 \mathrm{e}-09$ \\
\hline${ }^{39} \mathrm{Ar}$ & $0.0 \mathrm{e}+00$ & $1.7 \mathrm{e}+00$ & $1.7 \mathrm{e}+00$ & 2. $1 \mathrm{e}+00$ & ${ }^{230} \mathrm{Th}$ & $7.8 \mathrm{e}-02$ & $0.0 \mathrm{e}+00$ & $7.8 \mathrm{e}-02$ & $9.7 \mathrm{e}-02$ \\
\hline${ }^{40} \mathrm{~K}$ & $2.2 \mathrm{e}-04$ & $4.3 \mathrm{e}-01$ & $4.3 \mathrm{e}-01$ & $5.3 \mathrm{e}-01$ & ${ }^{232} \mathrm{Th}$ & $7.8 \mathrm{e}-01$ & $2.5 \mathrm{e}-05$ & $7.8 \mathrm{e}-01$ & $9.6 \mathrm{e}-01$ \\
\hline${ }^{41} \mathrm{Ca}$ & $0.0 \mathrm{e}+00$ & $2.3 \mathrm{e}+00$ & $2.3 \mathrm{e}+00$ & $2.8 \mathrm{e}+00$ & ${ }^{231} \mathrm{~Pa}$ & $3.9 \mathrm{e}-02$ & $0.0 \mathrm{e}+00$ & $3.9 \mathrm{e}-02$ & $4.8 \mathrm{e}-02$ \\
\hline${ }^{59} \mathrm{Ni}$ & $2.0 \mathrm{e}-03$ & $5.7 \mathrm{e}-02$ & $5.7 \mathrm{e}-02$ & $7.3 \mathrm{e}-02$ & ${ }^{232} \mathrm{U}$ & $0.0 \mathrm{e}+00$ & $4.5 \mathrm{e}-01$ & $4.5 \mathrm{e}-01$ & $5.6 \mathrm{e}-01$ \\
\hline${ }^{63} \mathrm{Ni}$ & $5.3 \mathrm{e}-05$ & $6.6 \mathrm{e}+00$ & $6.6 \mathrm{e}+00$ & $8.2 \mathrm{e}+00$ & ${ }^{233} \mathrm{U}$ & $2.5 \mathrm{e}-01$ & $2.1 \mathrm{e}-01$ & $4.6 \mathrm{e}-01$ & $5.7 \mathrm{e}-01$ \\
\hline${ }^{60} \mathrm{Co}$ & $1.4 \mathrm{e}+04$ & $0.0 \mathrm{e}+00$ & $1.4 \mathrm{e}+04$ & $1.7 \mathrm{e}+04$ & ${ }^{234} \mathrm{U}$ & $2.0 \mathrm{e}-03$ & $5.2 \mathrm{e}+02$ & $5.2 \mathrm{e}+02$ & $6.4 \mathrm{e}+02$ \\
\hline${ }^{85} \mathrm{Kr}$ & 7.0e+01 & $2.2 \mathrm{e}+02$ & $2.9 \mathrm{e}+02$ & $3.6 \mathrm{e}+02$ & ${ }^{235} \mathrm{U}$ & $1.4 \mathrm{e}+01$ & $2.1 \mathrm{e}+01$ & $3.6 \mathrm{e}+01$ & $4.4 \mathrm{e}+01$ \\
\hline${ }^{90} \mathrm{Sr}$ & $8.9 \mathrm{e}+04$ & $2.8 \mathrm{e}+03$ & $9.2 \mathrm{e}+04$ & $1.1 \mathrm{e}+05$ & ${ }^{236} \mathrm{U}$ & $3.2 \mathrm{e}-06$ & $2.4 \mathrm{e}+01$ & $2.4 \mathrm{e}+01$ & $2.9 \mathrm{e}+01$ \\
\hline${ }^{93} \mathrm{Zr}$ & $0.0 \mathrm{e}+00$ & $9.8 \mathrm{e}-02$ & $9.8 \mathrm{e}-02$ & $1.2 \mathrm{e}-01$ & ${ }^{238} \mathrm{U}$ & $1.1 \mathrm{e}+03$ & $1,4 \mathrm{e}+02$ & $1.2 \mathrm{e}+03$ & $1.5 \mathrm{e}+03$ \\
\hline${ }^{93 \mathrm{~m}} \mathrm{Nb}$ & $0.0 \mathrm{e}+00$ & $9.2 \mathrm{e}+00$ & $9.2 \mathrm{e}+00$ & $1.1 \mathrm{e}+01$ & ${ }^{237} \mathrm{~Np}$ & $2.4 \mathrm{e}-01$ & $2.3 \mathrm{e}+00$ & $2.5 \mathrm{e}+00$ & $3.1 \mathrm{e}+00$ \\
\hline${ }^{94} \mathrm{Nb}$ & $4.6 \mathrm{e}-05$ & $2.6 \mathrm{e}-01$ & $2.6 \mathrm{e}-01$ & $3.2 \mathrm{e}-01$ & PU-51 & $3.5 \mathrm{e}+01$ & $-3.5 \mathrm{e}+01$ & $0.0 \mathrm{e}+00$ & $0.0 \mathrm{e}+00$ \\
\hline${ }^{99} \mathrm{Tc}$ & $5.1 \mathrm{e}-07$ & $7.7 \mathrm{e}+01$ & $7.7 \mathrm{e}+01$ & $9.5 \mathrm{e}+01$ & PU-52 & $1.5 \mathrm{e}+01$ & $-1.5 \mathrm{e}+01$ & $0.0 \mathrm{e}+00$ & $0.0 \mathrm{e}+00$ \\
\hline${ }^{107} \mathrm{Pd}$ & $0.0 \mathrm{e}+00$ & $3.2 \mathrm{e}-03$ & $3.2 \mathrm{e}-03$ & $4.0 \mathrm{e}-03$ & ${ }^{238} \mathrm{Pu}$ & $9.2 \mathrm{e}+01$ & $1.6 \mathrm{e}+01$ & $1.1 \mathrm{e}+02$ & $1.3 \mathrm{e}+02$ \\
\hline${ }^{113 \mathrm{~m}^{\mathrm{C}} \mathrm{Cd}}$ & $0.0 \mathrm{e}+00$ & $2.1 \mathrm{e}+00$ & $2.1 \mathrm{e}+00$ & $2.6 \mathrm{e}+00$ & ${ }^{239} \mathrm{Pu}$ & $7.6 \mathrm{e}+01$ & $4.7 \mathrm{e}+01$ & $1.2 \mathrm{e}+02$ & $1.5 \mathrm{e}+02$ \\
\hline${ }^{12 \mathrm{~m} 1} \mathrm{Sn}$ & $0.0 \mathrm{e}+00$ & $8.2 \mathrm{e}+00$ & $8.2 \mathrm{e}+00$ & $1.0 \mathrm{e}+01$ & ${ }^{240} \mathrm{Pu}$ & $1.7 \mathrm{e}+01$ & $2.0 \mathrm{e}+01$ & $3.7 \mathrm{e}+01$ & $4.6 \mathrm{e}+01$ \\
\hline${ }^{126} \mathrm{Sn}$ & $0.0 \mathrm{e}+00$ & $9.6 \mathrm{e}-02$ & $9.6 \mathrm{e}-02$ & $1.2 \mathrm{e}-01$ & ${ }^{241} \mathrm{Pu}$ & $1.4 \mathrm{e}+02$ & $3.1 \mathrm{e}+02$ & $4.5 \mathrm{e}+02$ & $5.6 \mathrm{e}+02$ \\
\hline${ }^{129} \mathrm{I}$ & $1.0 \mathrm{e}-04$ & $2.1 \mathrm{e}-03$ & $2.2 \mathrm{e}-03$ & $2.7 \mathrm{e}-03$ & ${ }^{242} \mathrm{Pu}$ & $5.4 \mathrm{e}-03$ & $7.4 \mathrm{e}-03$ & $1.3 \mathrm{e}-02$ & $1.6 \mathrm{e}-02$ \\
\hline${ }^{135} \mathrm{Cs}$ & $0.0 \mathrm{e}+00$ & $7.3 \mathrm{e}-02$ & $7.3 e-02$ & $9.0 \mathrm{e}-02$ & ${ }^{241} \mathrm{Am}$ & $1.6 \mathrm{e}+01$ & $1.9 \mathrm{e}+01$ & $3.4 \mathrm{e}+01$ & $4.2 \mathrm{e}+01$ \\
\hline${ }^{137} \mathrm{Cs}$ & $1.4 \mathrm{e}+05$ & $3.4 \mathrm{e}+03$ & $1.5 \mathrm{e}+05$ & $1.8 \mathrm{e}+05$ & ${ }^{243} \mathrm{Am}$ & $8.9 \mathrm{e}-03$ & $3.3 \mathrm{e}-03$ & $1.2 \mathrm{e}-02$ & $1.5 \mathrm{e}-02$ \\
\hline${ }^{133} \mathrm{Ba}$ & $5.3 \mathrm{e}-02$ & $0.0 \mathrm{e}+00$ & $5.3 \mathrm{e}-02$ & $6.5 \mathrm{e}-02$ & ${ }^{243} \mathrm{Cm}$ & $1.9 \mathrm{e}-01$ & $0.0 \mathrm{e}+00$ & $1.9 \mathrm{e}-01$ & $2.3 \mathrm{e}-01$ \\
\hline
\end{tabular}




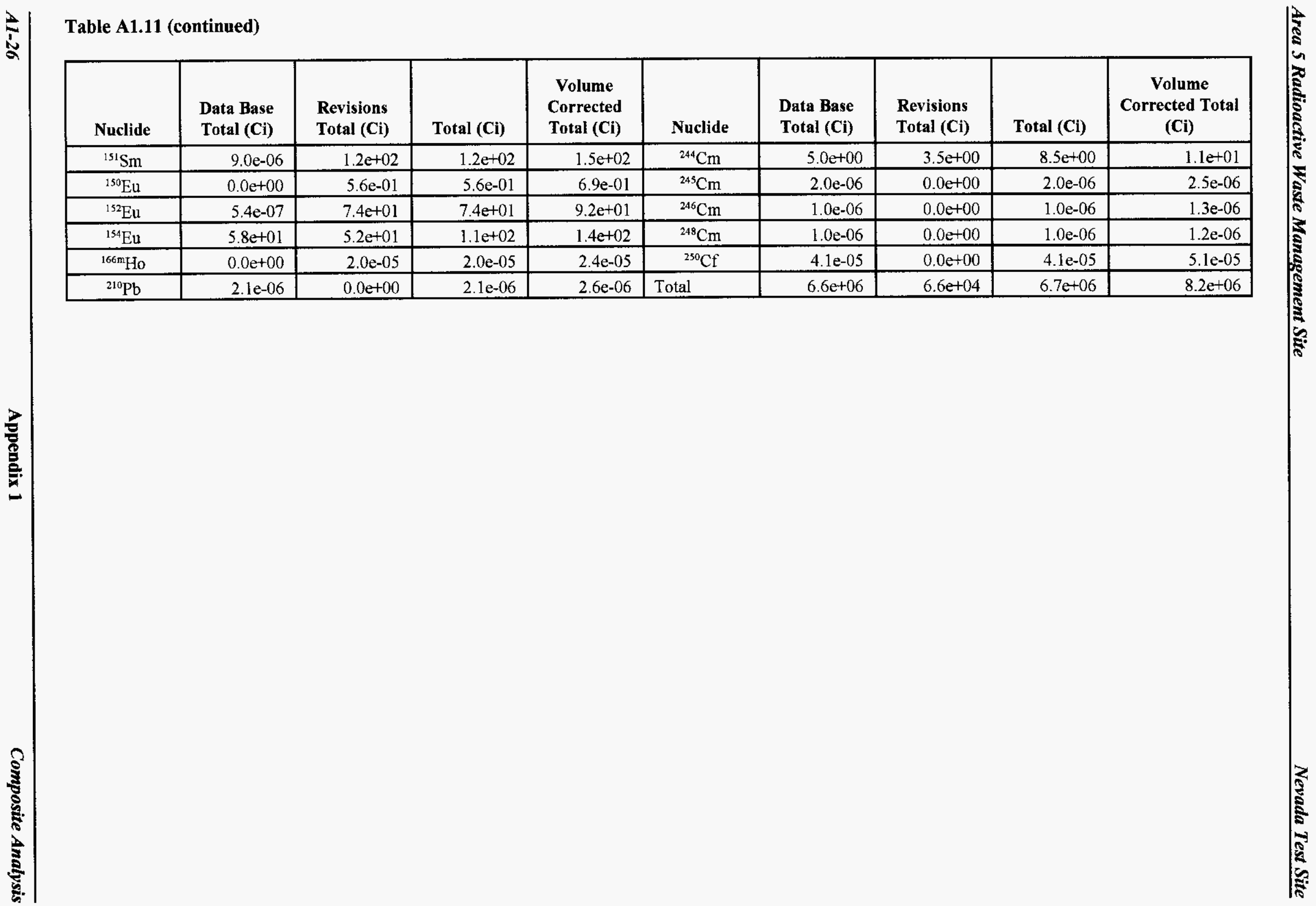


Table A1.12 Estimated Mean and Standard Deviation of Area 5 RWMS Inventory at Closure in 2028 for Radionuclides Meeting Screening Criteria

\begin{tabular}{|c|c|c|c|c|c|c|}
\hline Nuclide & $\begin{array}{c}\text { Mean of Pre- } \\
1988 \text { Inventory } \\
\text { at } 1988(\mathrm{Ci})\end{array}$ & $\begin{array}{l}\text { Standard } \\
\text { Deviation } \\
\end{array}$ & $\begin{array}{c}\text { Mean of Post- } \\
1988 \text { Inventory } \\
\text { at } 2028(\mathrm{Ci}) \\
\end{array}$ & $\begin{array}{l}\text { Standard } \\
\text { Deviation } \\
\end{array}$ & $\begin{array}{c}\text { Mean of Total } \\
\text { Inventory at } \\
2028 \text { (Ci) } \\
\end{array}$ & Standard Deviation \\
\hline${ }^{3} \mathrm{H}$ & $7.6 e+06$ & $8.6 \mathrm{e}+05$ & $8.4 e+05$ & $2.1 \mathrm{e}+06$ & $1.6 e+06$ & $2.1 e+06$ \\
\hline${ }^{14} \mathrm{C}$ & $3.2 \mathrm{e}+00$ & $4.5 \mathrm{e}+00$ & $1.1 \mathrm{e}+01$ & $2.7 \mathrm{e}+01$ & $1.4 \mathrm{e}+01$ & $2.4 \mathrm{e}+01$ \\
\hline${ }^{36} \mathrm{Cl}$ & $7.8 \mathrm{e}-01$ & $1.1 \mathrm{e}+00$ & $4.1 e-07$ & $1.0 \mathrm{e}-06$ & $7.7 e-01$ & $1.2 \mathrm{e}+00$ \\
\hline${ }^{39} \mathrm{Ar}$ & $4.4 \mathrm{e}+00$ & $5.2 \mathrm{e}+00$ & $0.0 \mathrm{e}+00$ & $0.0 \mathrm{e}+00$ & $3.8 \mathrm{e}+00$ & $4.6 \mathrm{e}+00$ \\
\hline${ }^{40} \mathrm{~K}$ & $1.1 \mathrm{e}+00$ & $1.3 e+00$ & $0.0 \mathrm{e}+00$ & $0.0 \mathrm{e}+00$ & $1.1 \mathrm{e}+00$ & $1.3 \mathrm{e}+00$ \\
\hline${ }^{85} \mathrm{Kr}$ & $6.5 \mathrm{e}+02$ & $6.7 e+02$ & $7.0 \mathrm{e}-02$ & $1.7 \mathrm{e}-01$ & $4.6 e+01$ & $4.7 \mathrm{e}+01$ \\
\hline${ }^{90} \mathrm{Sr}$ & $2.3 e+05$ & $2.6 \mathrm{e}+05$ & $1.3 e+01$ & $3.2 \mathrm{e}+01$ & $9.0 \mathrm{e}+04$ & $9.8 \mathrm{e}+04$ \\
\hline${ }^{94} \mathrm{Nb}$ & $6.7 \mathrm{e}-01$ & $1.0 \mathrm{e}+00$ & $0.0 \mathrm{e}+00$ & $0.0 \mathrm{e}+00$ & $6.5 \mathrm{e}-01$ & $9.9 \mathrm{e}-01$ \\
\hline${ }^{99} \mathrm{Tc}$ & $4.1 \mathrm{e}+02$ & $6.2 e+02$ & $7.7 \mathrm{e}+01$ & $1.9 \mathrm{e}+02$ & $4.9 \mathrm{e}+02$ & $6.3 e+02$ \\
\hline${ }^{126} \mathrm{Sn}$ & $2.5 \mathrm{e}-01$ & $2.9 \mathrm{e}-01$ & $3.4 \mathrm{e}-05$ & $8.4 \mathrm{e}-05$ & $2.4 \mathrm{e}-01$ & $2.9 \mathrm{e}-01$ \\
\hline${ }^{137} \mathrm{Cs}$ & $3.6 \mathrm{e}+05$ & $1.4 \mathrm{e}+05$ & $1.3 \mathrm{e}+01$ & $3.3 e+01$ & $1.4 \mathrm{e}+05$ & $1.4 \mathrm{e}+05$ \\
\hline${ }^{210} \mathrm{~Pb}$ & $5.3 \mathrm{e}-06$ & $5.9 \mathrm{e}-06$ & $9.7 \mathrm{e}-02$ & $2.4 \mathrm{e}-01$ & $3.2 \mathrm{e}+01$ & $7.0 \mathrm{e}+01$ \\
\hline${ }^{226} \mathrm{Ra}$ & $4.5 \mathrm{e}+01$ & $5.2 \mathrm{e}+01$ & $2.4 \mathrm{e}-01$ & $5.9 \mathrm{e}-01$ & $4.5 \mathrm{e}+01$ & $1.0 \mathrm{e}+02$ \\
\hline${ }^{228} \mathrm{Ra}$ & $0.0 \mathrm{e}+00$ & $0.0 \mathrm{e}+00$ & $0.0 \mathrm{e}+00$ & $0.0 \mathrm{e}+00$ & $2.2 \mathrm{e}+00$ & $8.4 \mathrm{e}+00$ \\
\hline${ }^{227} \mathrm{Ac}$ & $7.0 \mathrm{e}-01$ & $6.0 \mathrm{e}-01$ & $2.8 \mathrm{e}-01$ & $6.9 \mathrm{e}-01$ & $5.7 \mathrm{e}-01$ & $8.6 e-01$ \\
\hline${ }^{228} \mathrm{Th}$ & $4.5 e-02$ & $4.1 \mathrm{e}-02$ & $3.8 \mathrm{e}+00$ & $9.2 \mathrm{e}+00$ & $5.1 \mathrm{e}+00$ & $8.9 e+00$ \\
\hline${ }^{229} \mathrm{Th}$ & $2.5 e-09$ & $2.9 \mathrm{e}-09$ & $6.1 \mathrm{e}-06$ & $1.5 \mathrm{e}-05$ & $4.5 \mathrm{e}-03$ & $1.0 \mathrm{e}-02$ \\
\hline${ }^{230} \mathrm{Th}$ & $2.0 \mathrm{e}-01$ & $1.7 \mathrm{e}-01$ & $1.6 e+00$ & $3.9 \mathrm{e}+00$ & $2.3 \mathrm{e}+00$ & $5.2 \mathrm{e}+00$ \\
\hline${ }^{232} \mathrm{Th}$ & $1.9 \mathrm{e}+00$ & $1.7 \mathrm{e}+00$ & $5.0 \mathrm{e}+00$ & $1.2 \mathrm{e}+01$ & $7.0 \mathrm{e}+00$ & $1.2 \mathrm{e}+01$ \\
\hline${ }^{231} \mathrm{~Pa}$ & $9.9 \mathrm{e}-02$ & $1.2 \mathrm{e}-01$ & $1.6 \mathrm{e}-01$ & $4.0 \mathrm{e}-01$ & $3.4 \mathrm{e}-01$ & $6.2 \mathrm{e}-01$ \\
\hline${ }^{233} \mathrm{U}$ & $1.2 \mathrm{e}+00$ & $9.8 \mathrm{e}-01$ & $3.4 \mathrm{e}-03$ & $8.3 e-03$ & $1.2 \mathrm{e}+00$ & $9.7 \mathrm{e}-01$ \\
\hline${ }^{234} \mathrm{U}$ & $1.3 e+03$ & $9.0 \mathrm{e}+02$ & $1.4 \mathrm{e}+03$ & $3.5 \mathrm{e}+03$ & $2.7 \mathrm{e}+03$ & $3.6 \mathrm{e}+03$ \\
\hline${ }^{235} \mathrm{U}$ & $9.1 \mathrm{e}+01$ & $6.1 e+01$ & $8.0 \mathrm{e}+01$ & $2.0 \mathrm{e}+02$ & $1.7 \mathrm{e}+02$ & $2.0 \mathrm{e}+02$ \\
\hline${ }^{236} \mathrm{U}$ & $5.9 \mathrm{e}+01$ & $6.9 \mathrm{e}+01$ & $2.3 e+00$ & $5.6 \mathrm{e}+00$ & $6.1 \mathrm{e}+01$ & $6.9 \mathrm{e}+01$ \\
\hline${ }^{238} \mathrm{U}$ & $3.1 \mathrm{e}+03$ & $2.0 \mathrm{e}+03$ & $2.7 \mathrm{e}+03$ & $6.6 e+03$ & $5.7 \mathrm{e}+03$ & $6.9 e+03$ \\
\hline${ }^{237} \mathrm{~Np}$ & $6.4 \mathrm{e}+00$ & $4.0 \mathrm{e}+00$ & $2.1 \mathrm{e}-02$ & $5.1 \mathrm{e}-02$ & $6.3 e+00$ & $4.0 \mathrm{e}+00$ \\
\hline
\end{tabular}




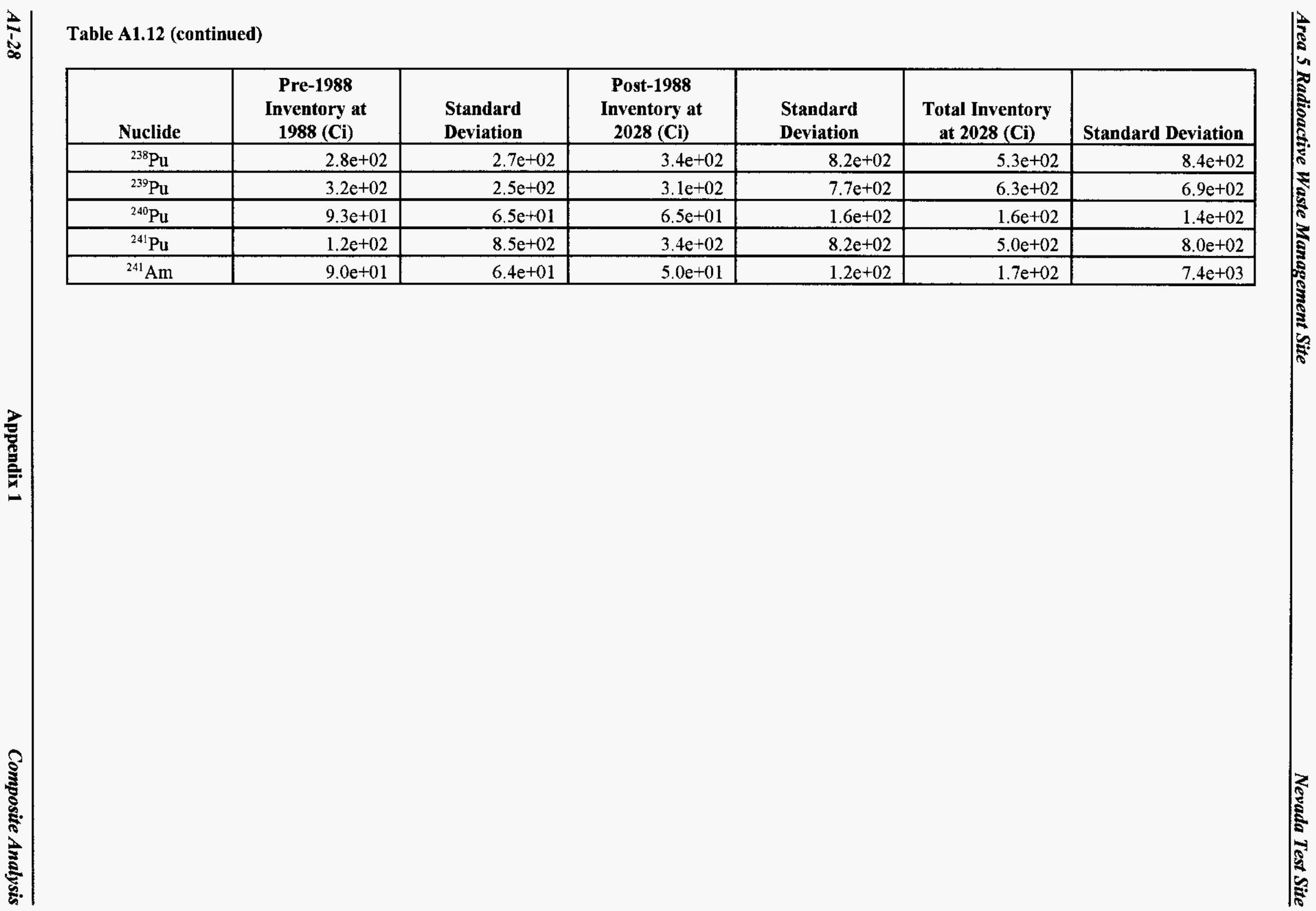




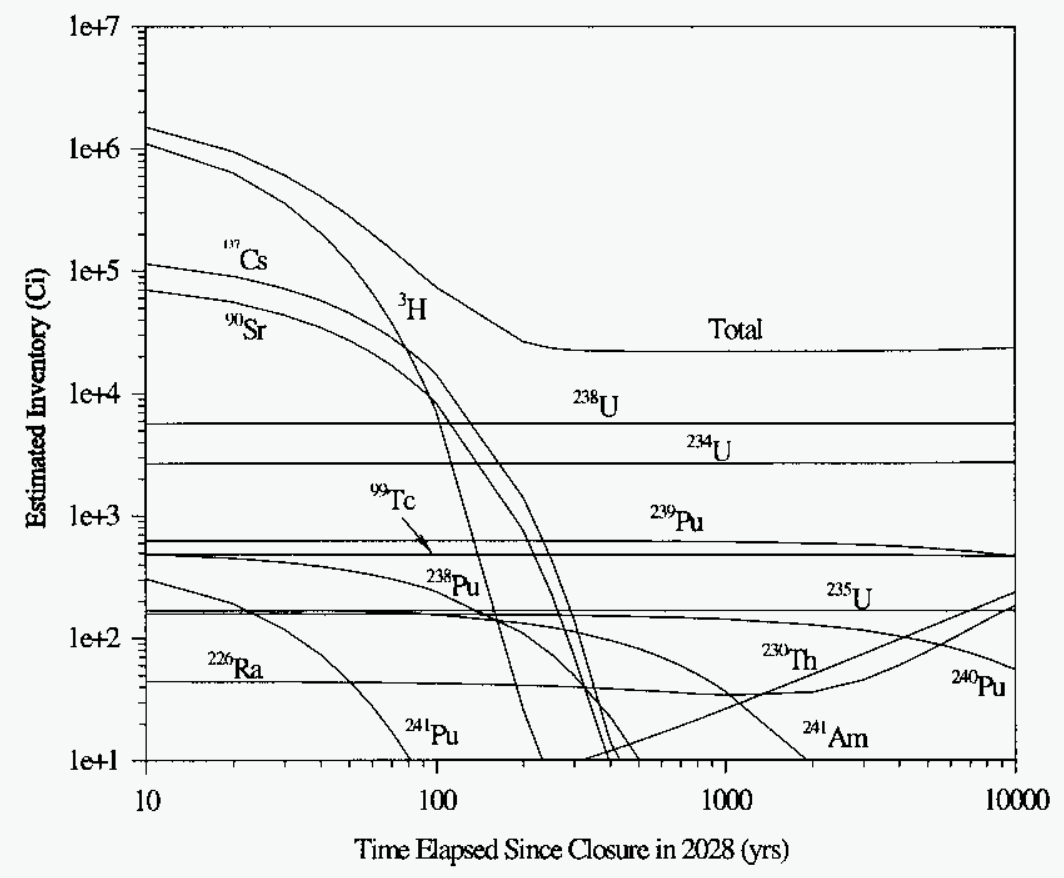

Figure A1.2 Estimated Mean Inventory Disposed in Shallow Pits and Trenches at the Area 5 RWMS as a Function of Time Considering Only Radioactive Decay and Ingrowth.

\section{A1.5.7 Estimated Inventory of the Greater Confinement Disposal and the Greater Confinement Disposal Test}

The initial inventory of wastes disposed in GCD units and the GCDT at the Area 5 RWMS is based on the inventory previously prepared by Chu and Bernard (1991) and subsequently revised (Cochran, 1997; personal communication). The inventory for GCD and GCDT includes wastes disposed from 1983 to 1989 when GCD operations ceased. This inventory was prepared from original shipping papers and is not believed to be subject to the completeness problems of the data base queries. Therefore, corrections were not applied to account for incomplete records. Activities were reported for individual radionuclides, but characterization was not likely to be complete. The inventory was revised using the same methods as used for the shallow pits and trenches. 


\section{A1.5.7.1 Estimated Volume of Greater Confinement Disposal and Greater Confinement Disposal Test Waste}

The external volume of waste disposed in GCD and GCDT was estimated from the number and sizes of packages reported to be disposed (Chu and Bernard, 1991). The external volume was estimated assuming that drums were 55-gallon drums and that boxes had dimensions of $4^{\prime} \times 4^{\prime} \times$ 7'. The external volume from the shipping records is estimated to be $293 \mathrm{~m}^{3}\left(1.0 \mathrm{e} 4 \mathrm{ft}^{3}\right)$. The physical volume of the boreholes can be estimated from the dimensions. Because packages are lowered by crane into the boreholes, a relatively low facility design factor is expected. A typical facility design factor of 0.75 was assumed. This should represent a very conservative value for GCD, given the difficulties of placing and closely stacking containers in the boreholes. Ten boreholes provide a maximum volume of $716 \mathrm{~m}^{3}\left(2.5 \mathrm{e} 4 \mathrm{ft}^{3}\right)$ for disposal. The true volume of GCD and GCDT waste is likely to lie between 293 and $716 \mathrm{~m}^{3}\left(1 \mathrm{e} 4\right.$ and $2.5 \mathrm{e}^{3} \mathrm{ft}^{3}$. Because these disposal records are believed to be complete and some GCD boreholes are known to be partially filled, the true volume is assumed to be close to the reported volume of $293 \mathrm{~m}^{3}\left(1 \mathrm{e} 4 \mathrm{ft}^{3}\right)$.

\section{A1.5.7.2 Final Inventory in Greater Confinement Disposal and the Greater Confinement Disposal Test}

The inventory for GCD and GCDT was estimated by combining the inventory from the disposal records with revisions calculated using the methods and parameters assumed for the shallow pits and trenches. Revisions were estimated for fission products and transuranic nuclides in uranium, missing uranium isotopes, and missing transuranic radionuclides. The revisions are generally insignificant relative to the GCD inventory and the shallow pits and trenches inventory. The GCD and GCDT inventory consists mostly of high-specific-activity ${ }^{3} \mathrm{H}$, nuclear weapon components, and sealed sources that are believed to be relatively well characterized. One potentially incompletely characterized waste stream is the irradiated stainless steel fuel cladding disposed in U5RWMS06U. The generator's shipping records list only ${ }^{60} \mathrm{Co},{ }^{90} \mathrm{Sr}$, and ${ }^{137} \mathrm{Cs}$ for this waste stream. While the cladding is likely to have contained additional fission and activation products, that unreported inventory is likely to be a small fraction of the inventory of these nuclides disposed in the shallow pits and trenches. Considering the greater depth of burial and lesser inventory, no revision for missing fission and activation products was performed for the fuel cladding.

The total GCD and GCDT inventory is estimated to be 3.1 e6 Ci as of 1991 (Table A1.13). The inventory is 84 percent ${ }^{3} \mathrm{H}, 13$ percent ${ }^{90} \mathrm{Sr}$, and slightly less than 1 percent ${ }^{137} \mathrm{Cs}$ on an activity basis. The estimated radionuclide inventories are plotted as a function of time in Figure A1.3. The inventory decreases rapidly over the first 400 years as ${ }^{3} \mathrm{H},{ }^{90} \mathrm{Sr}$, and ${ }^{137} \mathrm{Cs}$ decay. After approximately 300 years, ${ }^{239} \mathrm{Pu}$ becomes the most abundant radionuclide on an activity basis.

The generator waste characterization data for GCD waste is uncertain. Most GCD waste consists of nuclear weapon components and sealed sources. Because accurate accountability data must be maintained for nuclear weapon materials and sealed sources generally contain well-known 
Table A1.13 Estimated Inventory for the Area 5 RWMS GCD and GCDT Boreholes. Activities are reported for late 1991. The disposal records are from Chu and Bernard (1991) and Cochran (1997).

\begin{tabular}{cccc||cccc}
\hline & $\begin{array}{c}\text { Disposal } \\
\text { Records } \\
\text { Nuclide }\end{array}$ & $\begin{array}{c}\text { Revisions } \\
\text { (Ci) }\end{array}$ & $\begin{array}{c}\text { Total } \\
\text { (Ci) }\end{array}$ & Nuclide & $\begin{array}{c}\text { Disposal } \\
\text { Records }\end{array}$ & $\begin{array}{c}\text { Revisions } \\
\text { (Ci) }\end{array}$ & $\begin{array}{c}\text { Total } \\
\text { (Ci) }\end{array}$ \\
\hline${ }^{3} \mathrm{H}$ & $2.8 \mathrm{e}+06$ & $0.0 \mathrm{e}+00$ & $2.8 \mathrm{e}+06$ & ${ }^{236} \mathrm{U}$ & $0.0 \mathrm{e}+00$ & $1.2 \mathrm{e}-02$ & $1.2 \mathrm{e}-02$ \\
${ }^{60} \mathrm{Co}$ & $3.3 \mathrm{e}+03$ & $0.0 \mathrm{e}+00$ & $3.3 \mathrm{e}+03$ & ${ }^{238} \mathrm{U}$ & $2.5 \mathrm{e}+00$ & $8.1 \mathrm{e}-04$ & $2.5 \mathrm{e}+00$ \\
${ }^{90} \mathrm{Sr}$ & $4.2 \mathrm{e}+05$ & $1.0 \mathrm{e}-02$ & $4.2 \mathrm{e}+05$ & ${ }^{237} \mathrm{~Np}$ & $0.0 \mathrm{e}+00$ & $5.9 \mathrm{e}-03$ & $5.9 \mathrm{e}-03$ \\
${ }^{99} \mathrm{Tc}$ & $0.0 \mathrm{e}+00$ & $2.0 \mathrm{e}-01$ & $2.0 \mathrm{e}-01$ & ${ }^{238} \mathrm{Pu}$ & $0.0 \mathrm{e}+00$ & $6.3 \mathrm{e}+00$ & $6.3 \mathrm{e}+00$ \\
${ }^{137} \mathrm{Cs}$ & $1.9 \mathrm{e}+04$ & $0.0 \mathrm{e}+00$ & $1.9 \mathrm{e}+04$ & ${ }^{239} \mathrm{Pu}$ & $3.2 \mathrm{e}+02$ & $6.9 \mathrm{e}-03$ & $3.2 \mathrm{e}+02$ \\
${ }^{226} \mathrm{Ra}$ & $9.9 \mathrm{e}+01$ & $0.0 \mathrm{e}+00$ & $9.9 \mathrm{e}+01$ & ${ }^{240} \mathrm{Pu}$ & $0.0 \mathrm{e}+00$ & $3.2 \mathrm{e}+01$ & $3.2 \mathrm{e}+01$ \\
${ }^{227} \mathrm{Ac}$ & $8.0 \mathrm{e}+00$ & $0.0 \mathrm{e}+00$ & $8.0 \mathrm{e}+00$ & ${ }^{241} \mathrm{Pu}$ & $0.0 \mathrm{e}+00$ & $6.3 \mathrm{e}+02$ & $6.3 \mathrm{e}+02$ \\
${ }^{232} \mathrm{Th}$ & $2.0 \mathrm{e}-02$ & $0.0 \mathrm{e}+00$ & $2.0 \mathrm{e}-02$ & ${ }^{242} \mathrm{Pu}$ & $0.0 \mathrm{e}+00$ & $6.3 \mathrm{e}-03$ & $6.3 \mathrm{e}-03$ \\
${ }^{234} \mathrm{U}$ & $0.0 \mathrm{e}+00$ & $3.4 \mathrm{e}+00$ & $3.4 \mathrm{e}+00$ & ${ }^{241} \mathrm{Am}$ & $3.2 \mathrm{e}+01$ & $4.4 \mathrm{e}+01$ & $7.6 \mathrm{e}+01$ \\
${ }^{235} \mathrm{U}$ & $9.0 \mathrm{e}-02$ & $4.3 \mathrm{e}-02$ & $1.3 \mathrm{e}-01$ & & & \\
\end{tabular}

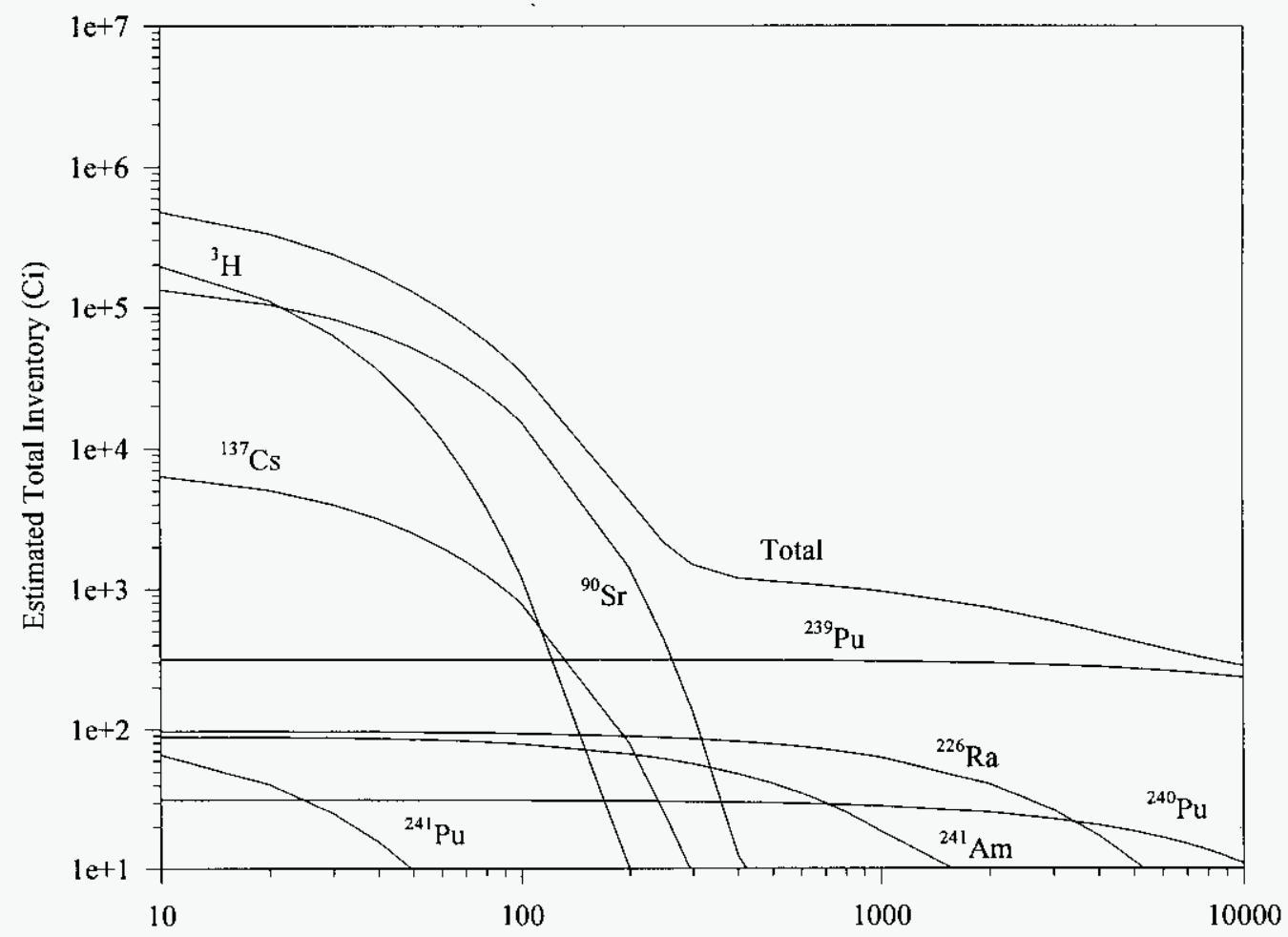

Time Elapsed Since 1991 (yrs)

Figure A1.3 Estimated Inventory Disposed in Greater Confinement Disposal and the Greater Confinement Disposal Test Boreholes at the Area 5 Radioactive Waste Management Site as a Function of Time Considering Only Radioactive Decay 
quantities of radioactive materials, both materials are expected to be relatively accurately characterized. Therefore, an interval extending from 0.1 to 10 times the estimated inventory should include the true inventory value.

\section{A1.6 References}

Atwood, C. L., and C. L. Hertzler, 1989. Review of Selected Radiation Monitoring Results at and Near the Radioactive Waste Management Site of the Nevada Test Site, 1970-1988. EGG-SARE-8555. EG\&G Idaho, Inc., Idaho Falls, Idaho.

ANSI, 1987. American National Standard for Nuclear Materials - Unirradiated Plutonium Scrap - Classification. ANSI N 15.10-1987, American National Standards Institute, New York, New York.

Barnes, M. G., J. J. Giacomini, R. T. Reiman, and B. Eliot, 1980. Nevada Test Site Radiological Assessment Project: Results for Frenchman Lake Region on Area 5. DOE/DP/01253-17. Desert Research Institute, Water Resource Center, University of Nevada, Las Vegas, Nevada.

Cochran, J., 1997. Personal communication from J. Cochran to G. Shott, December 9, 1997.

Chu, M. S., and E. A. Bernard, 1991. Waste Inventory and Preliminary Source Term Model for the Greater Confinement Disposal Site at the Nevada Test Site. SAND91-0170. Sandia National Laboratories, Albuquerque, New Mexico.

Croft, A. G., 1982. ORIGEN2: A Versatile Computer Code for Calculating the Nuclide Compositions and Characteristics of Nuclear Materials. Nuclear Technology 62: 335-352.

DOE, 2000. United States Nuclear Tests, July 1945 through September 1992. DOE/NV-209 (Rev. 15). U.S. Department of Energy, Nevada Operations Office, Las Vegas, Nevada.

, 1996a. Guidance for a Composite Analysis of the Impact of Interacting Source Terms on the Radiological Protection of the Public from Department of Energy Low-Level Waste Disposal Facilities. U.S. Department of Energy, Washington, D.C.

- 1996b. Final Environmental Impact Statement for the Nevada Test Site and Offsite Locations in the State of Nevada, August 1996. DOE/EIS 0243. U.S. Department of Energy, Nevada Operations Office, Las Vegas, Nevada.

1992. Nevada Test Site Defense Waste Acceptance Criteria, Certification, and Transfer Requirements. NVO-325. U.S. Department of Energy/Nevada Field Office, Las Vegas, Nevada. 
EPA, 1994. Guidance for Planning for the Data Quality Objective Process. EPA /600/R96/055. U.S. Environmental Protection Agency, Washington, D.C.

Farnham, N., 1997. Personal communication from N. Farnham to G. Shott, December 4, 1997.

FEMP, 1996. Radiological Characterization Manual. RM-0041. Fernald Environmental Management Program, Fernald, Ohio.

Gilbert, R. O., 1977. "Revised Total Amounts of ${ }^{239,240} \mathrm{Pu}$ in Surface Soil at Safety-Shot Sites, pp. 423-430. In: M. G. White, P. B. Dunaway, and D. L. Wireman, (eds)., Transuranics in Desert Ecosystems. NVO-181. U.S. Department of Energy, Nevada Operations Office, Las Vegas, Nevada.

McArthur, R. D., 1991. Radionuclides in Surface Soil at the Nevada Test Site. DOE/NV/1084502. Desert Research Institute, Water Resources Center, University of Nevada, Las Vegas, Nevada.

McArthur, R. D., and S. W. Mead, 1989. Nevada Test Site Radionuclide Inventory and Distribution Program: Report \# 5. Area 5, 11, 12, 15, 17, 18, 19, 25, 26, and 30. U.S. Department of Energy/Nevada Operations Office, Las Vegas, Nevada.

NRC, 1983. Low-Level Waste Licensing Branch Technical Position on Radioactive Waste Classification. U. S. Nuclear Regulatory Commission, Washington, D.C.

Price, L., 1992. Memorandum from L. Price to N. Olague, April 29, 1992.

Rich, B. L., S. L. Hinnefeld, C. R. Lagerquist, W. G. Mansfield, L. H. Munson, E. R. Wagner, and E. J. Vallaria, 1988. Health Physics Manual of Good Practices for Uranium Facilities. EGG-2530/UC-41, Idaho National Engineering Laboratory, Idaho Falls, ID.

Rothermich, N. E., and A. T. Vollmer, 1986. Analysis of Soils From the Area 5 Radioactive Waste Management Site: A Comparison of 1979 and 1984 Data. RWM-8. Reynolds Electrical \& Engineering Co., Inc., Las Vegas, Nevada.

Shott, G. J., L. E. Barker, S. E. Rawlinson, and M. J. Sully, 1997. Performance Assessment for the Area 5 Radioactive Waste Management Site at the Nevada Test Site, Nye County, Nevada, Revision 2.1. Bechtel Nevada, Las Vegas, Nevada. 


\section{This Page Intentionally Left Blank}




\section{APPENDIX 2}

\section{RELEASE AND TRANSPORT MODELS}




\section{CONTENTS}

A2.0 RELEASE AND TRANSPORT MODELS $\ldots \ldots \ldots \ldots \ldots \ldots \ldots \ldots \ldots$ A2-1

A2.1 Release of Nonvolatile Radionuclides . . . . . . . . . . . . . . . A2-1

A2.1.1 Selection of Compartment Model Dimensions ............ A2-3

A2.1.2 Estimation of First-Order Rate Constants . . . . . . . . . . . A2-11

A2.1.2.1 Advective Transport Rate Constants . .......... A2-11

A2.1.2.2 Burrowing Animal Rate Constants ............. A2-12

A2.1.2.3 Plant Uptake Rate Constants ............... A2-15

A2.1.2.4 Resuspension Rates ................... A2-22

A2.1.2.5 Soil Concentration and Surface Emission Rates ..... A A2-22

A2.1.3 Model Implementation $\ldots \ldots \ldots \ldots \ldots \ldots \ldots \ldots \ldots \ldots \ldots \ldots \ldots \ldots \ldots$

A2.2 Release of Volatile Radionuclides . . . . . . . . . . . . . . . . . A2-24

A2.3 Atmospheric Dispersion Model . ...................... A2-31

A2.3.1 Contaminated Soil Site Emissions $\ldots \ldots \ldots \ldots \ldots \ldots \ldots \ldots$ A2-31

A2.3.2 Atmospheric Dispersion Modeling ............... A2-34

A2.4 Screening Analysis of Upward Advection for Deep Waste Source

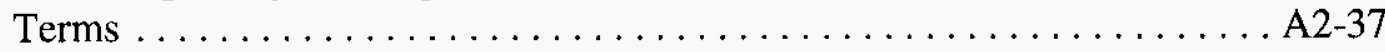

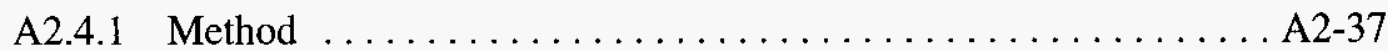

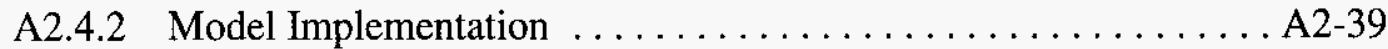

A2.4.3 Results ................................. A2-39

A2.5 Quality Assurance $\ldots \ldots \ldots \ldots \ldots \ldots \ldots \ldots \ldots \ldots \ldots \ldots \ldots \ldots \ldots \ldots \ldots \ldots \ldots, 41$

A2.5.1 Computer Code Implementation and Verification .......... A2-41

A2.5.1.1 Nonvolatile Radionuclide Release Model . ........ A2-41

A2.5.1.2 Volatile Radionuclide Release Model ........... A2-42

A2.5.1.3 Radiological Assessment Model .............. A2-42

A2.5.1.4 The ORIGEN2 Computer Code .............. A2-42

A2.5.1.5 The ISCLT Computer Code ............... A2-42

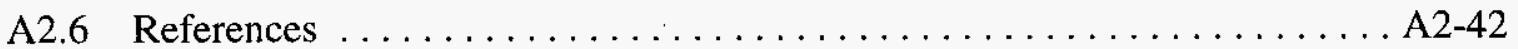




\section{List of Figures}

A2.1 Example of Transport Regions and Compartment Assignments for a Single

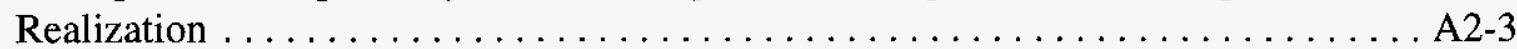

A2.2 Example Realization of Model Case $1 \ldots \ldots \ldots \ldots \ldots \ldots \ldots \ldots \ldots \ldots \ldots$. . . . . . . . . .

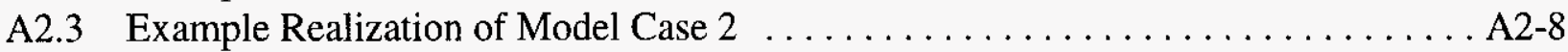

A2.4 Example Realization of Model Case $3 \ldots \ldots \ldots \ldots \ldots \ldots \ldots \ldots \ldots \ldots \ldots \ldots$

\section{List of Tables}

A2.1 Transport Regions and Disposal Unit Characteristics ................ A2-5

A2.2 Calculation of Compartment Depths $\left(\mathrm{d}_{4}, \mathrm{~d}_{3}, \mathrm{~d}_{2}\right.$, and $\left.\mathrm{d}_{1}\right)$ and Compartment Initial Activities $\left(A_{4}(0), A_{3}(0), A_{2}(0)\right.$, and $\left.A_{1}(0)\right)$ from Initial Inventory $(I(0))$ for the

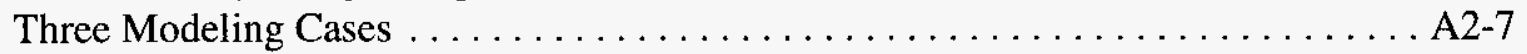

A2.3 Estimated Inventory of the Area 5 RWMS Shallow Pits and Trenches at Closure

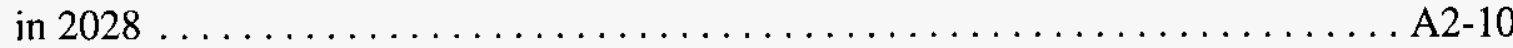

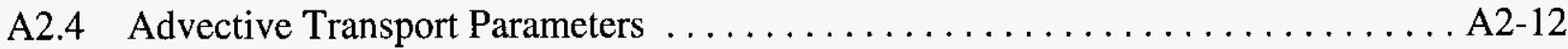

A2.5 Geometric Mean Distribution Coefficients for Sandy Soil Type . . . . . . . . A2-13

A2.6 Input Parameter Values Used to Estimate Burrowing Animal Rate Constants . . . A A2-16

A2.7 Input Parameters for Plant Uptake Rate Constants . . . . . . . . . . . . . . . . A2-20

A2.8 Assumed Values of the Plant-Soil Concentration Ratio . . . . . . . . . . . . A2-21

A2.9 Parameter Values for Random Variables in the Volatile Radionuclide Release Model ....................................... A2-30

A2.10 Fixed Parameter Values for the Volatile Radionuclide Release Model . . . . . . A2-31

A2.11 Soil Contamination Site Areas and Inventories as of 1990 Reported by McArthur (1991) and Gilbert (1977) ........................ A2-33

A2.12 Assumed Radionuclide Composition of PU-52 Scrape Plutonium and Activity from $1 \mathrm{~g}$ After 36 Years of Decay ........................... A2-33

A2.13 Assumed Resuspension Factors for Soil Sites .................... A2-34

A2.14 Soil Source Emission Areas Used in the ISCLT Model ............... A2-36

A2.15 Upward Advective Transport from Deep Waste Source Terms . ........... A2-40 


\section{ACRONYMS}

BN

CA

DOE

EPA

GCD

GMX

HTO

ISCLT

NTS

PAMP

RWMS

TEDE
Bechtel Nevada

Composite Analysis

U.S. Department of Energy

U.S. Environmental Protection Agency

Greater Confinement Disposal

Gadgets, Mechanics, and Explosives

tritiated water

Industrial Source Code Long-Term

Nevada Test Site

Performance Assurance Management Plan

Radioactive Waste Management Site

Total Effective Dose Equivalent 
This Page Intentionally Left Blank 


\section{A2.0 RELEASE AND TRANSPORT MODELS}

The conceptual model of radionuclide release and transport from the Area 5 Radioactive Waste Management Site (RWMS) assumes that radionuclides are transported upward to the land surface by advection of soil pore water, gaseous diffusion, and biological transport. Biological transport processes include root uptake, translocation, and decomposition of native plants rooted in waste and the burrowing of animals into the waste and cap. Radionuclides in surface soils are resuspended into the atmosphere and dispersed over the surrounding areas. Separate models are developed for the release of nonvolatile radionuclides and volatile radionuclides from the Area 5 RWMS, and the resuspension and atmospheric dispersion of contaminated surface soil.

\section{A2.1 Release of Nonvolatile Radionuclides}

The upward release of nonvolatile radionuclides from disposed waste is estimated using a compartment model. The compartment dimensions are dynamic, depending on randomly varying boundaries between three transport regions which have different release processes and release rates.

Plant growth in the Mojave and Transitional deserts of the Nevada Test Site (NTS) is limited by the availability of water. Potential evapotranspiration is approximately 14 times greater than precipitation. Infiltrating precipitation percolates a short distance into the alluvium before it is recycled back to the atmosphere. Because the uppermost aquifer occurs 240 meters (m) (790 feet [ft]) beneath the surface, water for plant growth is available only in the near-surface where infiltrating water cycles transiently. Plant root depth and density reflect the shallow depth of infiltration (Wallace et al., 1974, 1980). Chloride profiles provide further evidence of shallow plant rooting and solute absorption. Chloride at Mojave desert sites is typically depleted in the upper 0.3 to $1.5 \mathrm{~m}(0.9$ to $5 \mathrm{ft}$ ) of soil by plant uptake (Prudic, 1994). Although animal biomass and activity in surface soils is probably less directly influenced by water availability, empirically, vertebrate and invertebrate burrowing has also been observed to occur predominantly in a relatively shallow zone in the near surface (Anderson and Allred, 1964; McGrew, 1979; Cline et al., 1980; Winsor and Whicker, 1980; Reynolds and Wakkinen, 1987; Reynolds and Laundre, 1988; US Ecology, 1989).

The model assumes two regions of biological transport. There is a shallow surface layer containing most plant and animal biomass where upward transport is caused by plant root uptake and animal burrowing. The surface layer receives aboveground plant production and soil transported aboveground by burrowing animals. Burrowing animals, including mammals, and infiltrating water are assumed to transport contaminants deposited on the surface downward. Upward and downward transport process cause a slow-mixing of this layer.

Below the shallow surface layer, there is a deep layer with greatly reduced biomass where transport is predominantly upward. This region may extend into and beneath disposed waste. 
Animal burrowing in this region is assumed to be limited to invertebrates. Plant roots are assumed to be much more sparse in this region.

Beneath the two biological transport regions is a region where biological transport mechanisms become quantitatively insignificant, and upward transport occurs by liquid advection alone.

The model assumes that the waste and cap are divided into four compartments. The boundaries of each compartment are selected based on the randomly chosen thicknesses of the three transport regions relative to cap thickness. The deepest compartment loses radioactive material by radioactive decay and upward advection and receives activity through radioactive ingrowth only. The two intermediate compartments can release and receive activity through plant uptake, animal burrowing, liquid advection, and radioactive decay. The surface compartment receives activity from plant uptake and animal burrowing and loses activity by radioactive decay and resuspension into the atmosphere. Conditions in the surface compartment are assumed to be too dry to allow any significant upward liquid advection.

The equations of continuity for the four compartments, assuming a radionuclide that is a member of a nonbranching radioactive decay chain, can be written as:

$$
\begin{gathered}
\frac{d A_{1, j}}{d t}=A_{1, j}\left(-\lambda_{j}-L_{12, j}\right)+A_{1, j-1} \lambda_{j} \\
\frac{d A_{2, j}}{d t}=A_{2, j}\left(-\lambda_{j}-L_{23, j}-B_{24}-B_{23}-R_{24, j}-R_{23, j}\right)+A_{1, j} L_{12, j}+A_{2, j-1} \lambda_{j} \\
\frac{d A_{3, j}}{d t}=A_{3, j}\left(-\lambda_{j}-L_{34, j}-B_{34}-R_{34, j}\right)+A_{2, j}\left(L_{23, j}+B_{23}+R_{23, j}\right)+A_{3, j-1} \lambda_{j} \\
\frac{d A_{4, j}}{d t}=A_{4, j}\left(-\lambda_{j}-K\right)+A_{3, j}\left(L_{34, j}+B_{34}+R_{34, j}\right)+A_{2, j}\left(B_{24}+R_{24, j}\right)+A_{4, j-1} \lambda_{j}
\end{gathered}
$$

where

$$
\begin{aligned}
& \mathrm{A}_{\mathrm{m}, \mathrm{j}} \quad=\quad \text { activity of radionuclide } \mathrm{j} \text { in compartment } \mathrm{m}, \mathrm{Ci} ; \\
& \lambda_{\mathrm{j}}=\text { radiological decay constant for radionuclide } \mathrm{j}, \mathrm{yr}^{-1} \text {; } \\
& \mathrm{L}_{\mathrm{m}, \mathrm{n}, \mathrm{j}}=\text { liquid advection rate constant for transfer from compartment } \mathrm{m} \text { to } \\
& \text { compartment } \mathrm{n} \text { of radionuclide } \mathrm{j}, \mathrm{yr}^{-1} \text {; } \\
& \mathrm{B}_{\mathrm{m}, \mathrm{n}}=\quad \text { burrowing animal rate constant for transfer from compartment } \mathrm{m} \text { to } \\
& \text { compartment } \mathrm{n}, \mathrm{yr}^{-1} \text {; } \\
& \mathrm{R}_{\mathrm{m}, \mathrm{nj} \mathbf{j}}=\text { plant uptake rate constant for transfer from compartment } \mathrm{m} \text { to } \\
& \text { compartment } \mathrm{n} \text { of radionuclide } \mathrm{j}, \mathrm{yr}^{-1} \text {; and } \\
& \mathrm{K}=\text { shallow soil resuspension rate, } \mathrm{yr}^{-1} \text {. }
\end{aligned}
$$

The equations of continuity are derived assuming that the rate of change of the number of atoms in any compartment is equal to the difference between the inputs and outputs. Equation A2.1 has been converted into activity units by multiplying by the appropriate radiological decay constants. 


\section{A2.1.1 Selection of Compartment Model Dimensions}

The dimensions of the model compartments and their initial inventories are determined based on the thickness of the three transport regions relative to the cap and waste thickness. The boundaries between the transport regions are determined by randomly selecting the depth of the shallow surface layer with high biological activity, $\mathrm{x}_{4}$, and the maximum depth of biological activity, $\mathrm{x}_{2}$. The cap thickness, $\mathrm{x}_{3}$, and waste thickness, $\mathrm{x}_{\mathrm{w}}$, can also be randomly selected. Once the domains of the three transport regions are selected and the cap and waste thickness determined, the depths of the four compartments $\left(\mathrm{d}_{4}, \mathrm{~d}_{3}, \mathrm{~d}_{2}\right.$, and $\left.\mathrm{d}_{1}\right)$ can be determined based on where the maximum depth of biological activity lies relative to the cap and waste thickness (Figure A2.1).

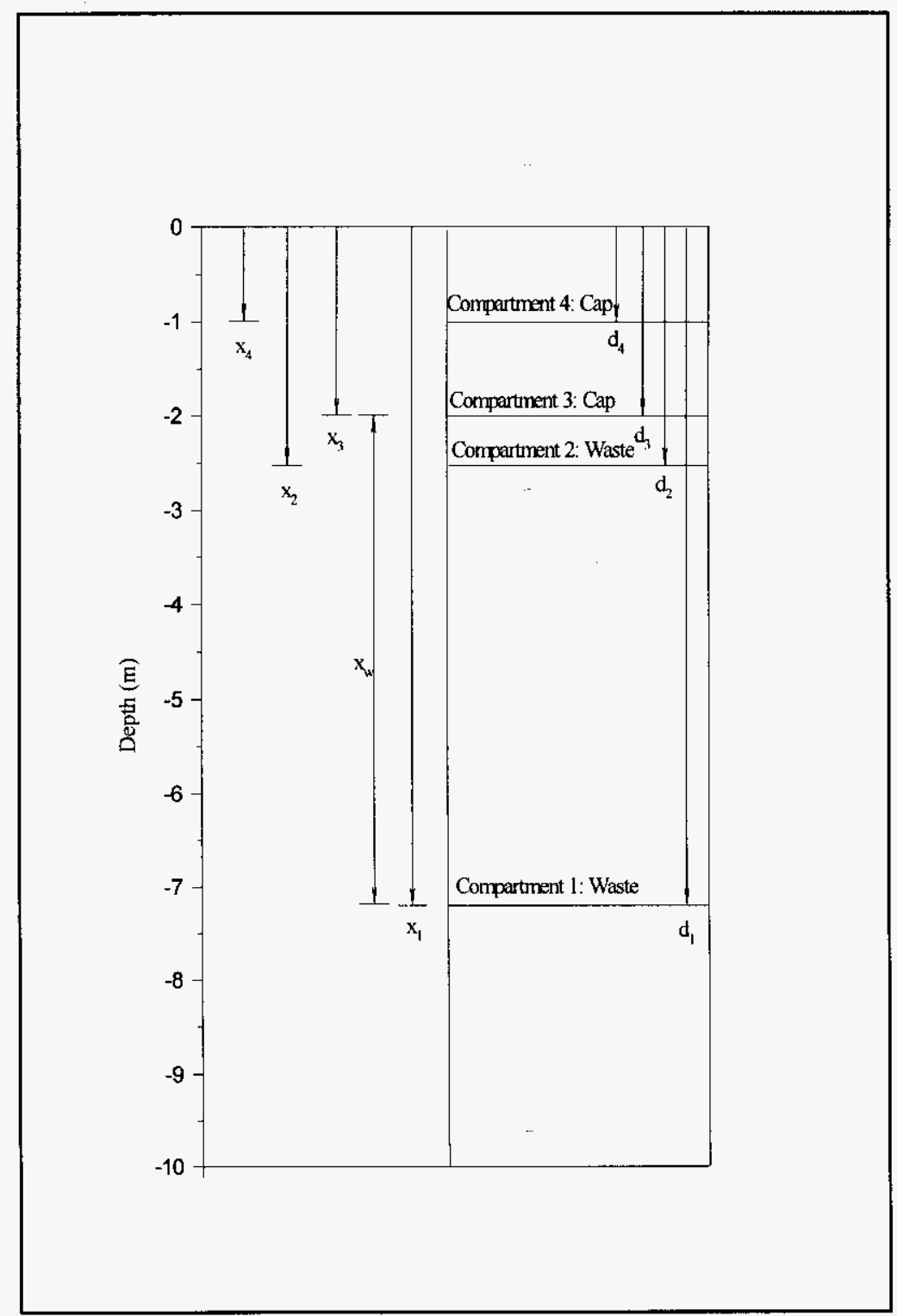

Figure A2.1 Example of Transport Regions and Compartment Assignments for a Single Realization. 
The depth of the shallow surface region was selected from a review of the literature describing plant rooting and animal burrowing in arid regions. The depth bounding 90 percent of root biomass or including all vertebrate burrows was selected as the boundary of the surface layer. These depths were found to range from 0.25 to $1.5 \mathrm{~m}$ ( 0.8 to $4.9 \mathrm{ft}$ ) (Tabler, 1964; Anderson and Allred, 1964; Chew and Chew, 1965; Barbour, 1973; Cline et al., 1980; Wallace et al., 1980; Klepper et al., 1985; Reynolds and Laundre, 1988; Link et al., 1994). Because the depth of the surface region, $\mathrm{x}_{4}$, combines several processes, it is assumed to vary uniformly over the reported range from 0.25 to $1.5 \mathrm{~m}(0.8$ to $4.9 \mathrm{ft}$ ) (Table A2.1).

The maximum depth of biological activity is set equal to the maximum rooting depth. Maximum rooting depth appears to exceed or be approximately equal to vertebrate and invertebrate burrowing depths. Maximum rooting depths were estimated from the literature describing arid sites (Tabler, 1964; Wallace and Romney, 1972; Sturges, 1977; Foxx et al., 1984; Klepper et al., 1985; Manning and Groeneveld, 1989; US Ecology, 1989; Link et al., 1994). Maximum rooting depths appear to be skewed toward shallower depths. Therefore, the maximum rooting depth, $\mathrm{x}_{2}$, is assumed to be lognormally distributed. The data set has an arithmetic mean of $2.5 \mathrm{~m}(8.2 \mathrm{ft})$ and standard deviation of $1.2 \mathrm{~m}(3.9 \mathrm{ft})$.

The assumed distribution of biological activity is imposed on the design of the waste disposal unit. Final closure plans are not available for the Area 5 RWMS. Therefore, design specifications for cap thickness, $\mathrm{x}_{3}$, are not available. Current work indicates that a range of thicknesses between 2 and $6 \mathrm{~m}(6.6$ to $20 \mathrm{ft})$ is reasonable. The thicknesses of waste in disposal units at the Area 5 RWMS is assumed to range from 2.4 to $7.9 \mathrm{~m}$ (11 to $26 \mathrm{ft})$ at the time of disposal. Subsidence occurring after closure may reduce waste thickness. Subsidence of pre-1990 waste has been estimated to range from 65 to 75 percent of the initial waste thickness (U.S. Department of Energy [DOE], 1998). Therefore, waste thickness, $\mathrm{x}_{\mathrm{w}}$, was assumed to vary uniformly between 0.6 and $7.9 \mathrm{~m}(2.6$ to $26 \mathrm{ft})$.

The transport region depths and disposal unit dimensions can be divided into three possible modeling cases, depending on whether the maximum rooting depth falls in the cap, in the waste, or beneath the disposal unit. Once the case is determined, the depths of the compartments $\left(d_{4}, d_{3}\right.$, $\mathrm{d}_{2}$, and $\mathrm{d}_{1}$ ) and the initial inventory in each compartment can be determined as listed in Table A2.2.

In Case (1), the maximum rooting depth falls in the cap. Three compartments are assigned to the cap to represent the shallow surface layer, a deep layer with biological activity, and a deep layer with no biological transport. The fourth compartment, which assumes no biological activity, is assigned to the waste layer (Figure A2.2).

In Case (2), the maximum rooting depth is deeper than the disposal unit. The cap is assigned two compartments and the waste one compartment. Biological transport occurs in all compartments (Figure A2.3). 
Table A2.1 Transport Regions and Disposal Unit Characteristics

\begin{tabular}{|c|c|c|c|}
\hline Parameter & Parameter Values & Distribution & Source \\
\hline $\begin{array}{l}\text { Depth of Surface } \\
\text { Region, } x_{4}\end{array}$ & $\begin{array}{l}\text { Min: } 0.25 \mathrm{~m} \\
\text { Max.: } 1.5 \mathrm{~m}\end{array}$ & Uniform & $\begin{array}{l}\text { The depth of the surface region represents the near-surface alluvium that contains } \\
\text { the majority of biological activity. This is assumed to correspond with a depth } \\
\text { including } 90 \text { percent of plant root biomass and the burrows of most vertebrates and } \\
\text { invertebrates. In the case of plant rooting, this depth is likely related to the depth } \\
\text { that precipitation commonly reaches. The data set was obtained from the literature } \\
\text { for arid sites (Tabler, 1964; Anderson and Allred, 1964; Chew and Chew, 1965; } \\
\text { Barbour, 1973; Cline et al., 1980; Wallace } \text { et al., 1980; Klepper } \text { et al., 1985; } \\
\text { Reynolds and Laundre, 1988; Link } \text { et al., 1994). A uniform distribution is selected } \\
\text { because several processes are lumped together in this parameter. }\end{array}$ \\
\hline Thickness of Cap, $x_{3}$ & $\begin{array}{l}\text { Min.: } 2 \mathrm{~m} \\
\text { Max.: } 6 \mathrm{~m}\end{array}$ & Uniform & A cap thickness of 2 to $6 \mathrm{~m}$ represents a reasonable design range. \\
\hline $\begin{array}{l}\text { Depth of Biological } \\
\text { Transport, } x_{2}\end{array}$ & $\begin{array}{l}\text { Mean: } 2.5 \mathrm{~m} \\
\text { Stand. Dev.: } 1.2 \\
\mathrm{~m}\end{array}$ & Lognormal & $\begin{array}{l}\text { The maximum depth of biological transport is assumed to be determined by the } \\
\text { maximum rooting depth of plants. A review of the literature identified values } \\
\text { ranging from } 1.5 \text { to } 9.1 \mathrm{~m} \text { (Tabler, 1964; Wallace and Romney, 1972; Sturges, } \\
\text { 1977; Foxx et al., 1984; Klepper et al., 1985; Manning and Groeneveld, 1989; US } \\
\text { Ecology, 1989; Link } \text { et al., 1994). The data are skewed toward the lower values. } \\
\text { The data were fit to a lognormal distribution with a mean of } 2.5 \mathrm{~m} \text { and a standard } \\
\text { deviation of } 1.2 \mathrm{~m} \text { (Kolmogorov-Smirnov Goodness of Fit } \mathrm{D}=0.27, \mathrm{p}=0.17, \mathrm{n}= \\
\text { 12). The lower limit of the distribution was set to } 1.6 \mathrm{~m} \text { to ensure that biological } \\
\text { transport was deeper than the surface layer. }\end{array}$ \\
\hline Thickness of Waste, $\mathbf{x}_{\mathrm{w}}$ & $\begin{array}{l}\text { Min.: } 0.6 \mathrm{~m} \\
\text { Max.: } 7.9 \mathrm{~m}\end{array}$ & Uniform & $\begin{array}{l}\text { Unsubsided waste thickness ranges from the thickness of two } 4^{\prime} \times 4^{\prime} \times 7^{\prime} \text { boxes } \\
(2.4 \mathrm{~m} \text { to } 7.9 \mathrm{~m} \text { ), the thickness of P03U. Assuming a maximum subsidence of } 0.75 \\
\text { (DOE, 1998b), the range of thickness is } 0.6 \text { to } 7.9 \mathrm{~m} \text {. }\end{array}$ \\
\hline $\begin{array}{l}\text { Waste Disposal Unit } \\
\text { Area, A }\end{array}$ & $\begin{array}{l}\text { Mean.: } 1.2 \mathrm{e} 5 \mathrm{~m}^{2} \\
\text { Stand. Dev.: } \\
1.5 \mathrm{e} 4 \mathrm{~m}^{2}\end{array}$ & Normal & $\begin{array}{l}\text { The area of the pre-1988 waste disposal units was estimated in Appendix } 1 \text { to vary } \\
\text { from } 4.4 \mathrm{e} 4 \text { to } 4.6 \mathrm{e} 4 \mathrm{~m}^{2} \text {. The area of the post- } 1988 \text { disposal units was estimated to } \\
\text { be } 7.5 \mathrm{e} 4 \mathrm{~m}^{2} \text {. The total area was estimated as the sum. The parameter is assumed to } \\
\text { be normally distributed with a coefficient of variation of } 0.125 \text {. }\end{array}$ \\
\hline
\end{tabular}


Table A2.1 (continued)

\begin{tabular}{llll}
\hline Parameter & Parameter Values & Distribution & Source \\
\hline Cap Bulk Density, $\rho_{\mathrm{s}}$ & $\begin{array}{l}\text { Mean: } 1.57 \mathrm{~g} / \mathrm{cm}^{3} \\
\text { Stand. Dev.: } 0.06\end{array}$ & Normal & $\begin{array}{l}\text { The cap bulk density was estimated for shallow alluvium at the Area } 5 \mathrm{RWMS} \text { as } \\
\mathrm{g} / \mathrm{m}^{3}\end{array}$ \\
& $\begin{array}{l}\text { described by Istok } \text { et al. (1994). The mean is assumed to be } 1.57 \mathrm{~g} / \mathrm{cm}^{3} \text { and the } \\
\text { standard deviation } 0.06 . \text { The lower and upper limits were set at } 1.39 \text { and } 1.80, \\
\text { respectively. }\end{array}$ \\
\hline $\begin{array}{l}\text { Waste Bulk Density, } 0.3 \mathrm{~g} / \mathrm{cm}^{3} \\
\rho_{\mathrm{w}}\end{array}$ & Uniform $1.8 \mathrm{~g} / \mathrm{cm}^{3}$ & & $\begin{array}{l}\text { The bulk density of waste is assumed to vary uniform between the minimum value } \\
\text { reported by DOE (1998) and the maximum bulk density of alluvium, } 0.3 \text { to } \\
1.8 \mathrm{~g} / \mathrm{cm}^{3} .\end{array}$ \\
\hline
\end{tabular}


Table A2.2 Calculation of Compartment Depths $\left(d_{4}, d_{3}, d_{2}\right.$, and $\left.d_{1}\right)$ and Compartment Initial Activities $\left(A_{4}(0), A_{3}(0), A_{2}(0)\right.$, and $\left.A_{1}(0)\right)$ from Initial Inventory $(I(0))$ for the Three Modeling Cases

\begin{tabular}{cccc}
\hline Parameter & $\begin{array}{c}\text { Case 1: } \mathbf{x}_{2} \leq \mathrm{x}_{3} \\
\text { (Rooting in Cap) }\end{array}$ & $\begin{array}{c}\text { Case 2: } \mathrm{x}_{2} \geq \mathbf{x}_{1} \\
\text { (Rooting Below Waste) }\end{array}$ & $\begin{array}{c}\text { Case 3: } \mathrm{x}_{1}>\mathrm{x}_{2}>\mathrm{x}_{\mathbf{3}} \\
\text { (Rooting in Waste) }\end{array}$ \\
\hline $\mathrm{d}_{4}$ & $\mathrm{x}_{4}$ & $\mathrm{x}_{4}$ & $\mathrm{x}_{4}$ \\
$\mathrm{~d}_{3}$ & $\mathrm{x}_{2}$ & $\mathrm{x}_{3}$ & $\mathrm{x}_{3}$ \\
$\mathrm{~d}_{2}$ & $\mathrm{x}_{3}$ & $\mathrm{x}_{3}+\mathrm{x}_{\mathrm{w}}$ & $\mathrm{x}_{2}$ \\
$\mathrm{~d}_{1}$ & $\mathrm{x}_{3}+\mathrm{x}_{\mathrm{w}}$ & $\mathrm{x}_{3}+\mathrm{x}_{\mathrm{w}}$ & $\mathrm{x}_{3}+\mathrm{x}_{\mathrm{w}}$ \\
$\mathrm{A}_{4}(0)$ & 0 & 0 & 0 \\
$\mathrm{~A}_{3}(0)$ & 0 & 0 & 0 \\
$\mathrm{~A}_{2}(0)$ & 0 & $\mathrm{I}(0)$ & $\left(\mathrm{d}_{2}-\mathrm{d}_{3}\right) /\left(\mathrm{d}_{1}-\mathrm{d}_{3}\right) \mathrm{I}(0)$ \\
$\mathrm{A}_{1}(0)$ & $\mathrm{I}(0)$ & 0 & $\left(\mathrm{~d}_{1}-\mathrm{d}_{2}\right) /\left(\mathrm{d}_{1}-\mathrm{d}_{3}\right) \mathrm{I}(0)$ \\
\hline
\end{tabular}

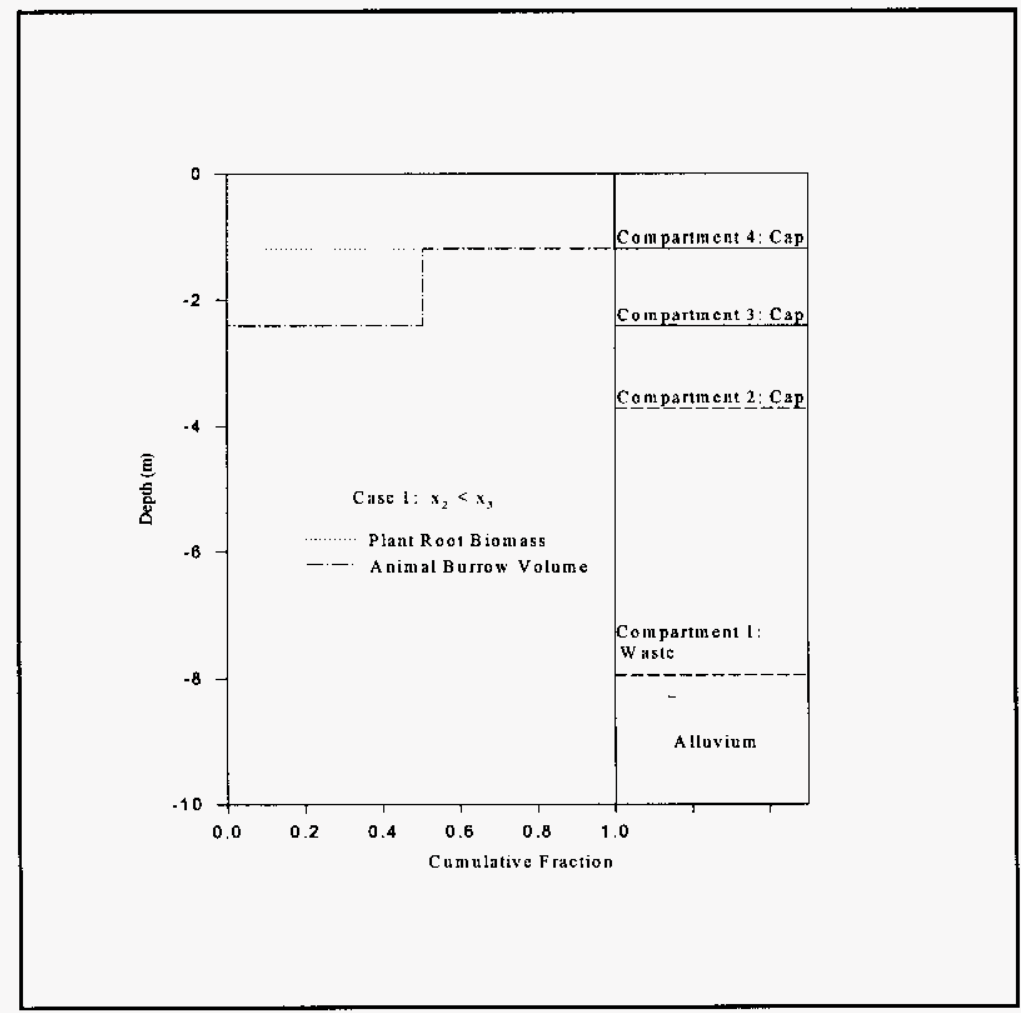

Figure A2.2 Example Realization of Model Case 1. 


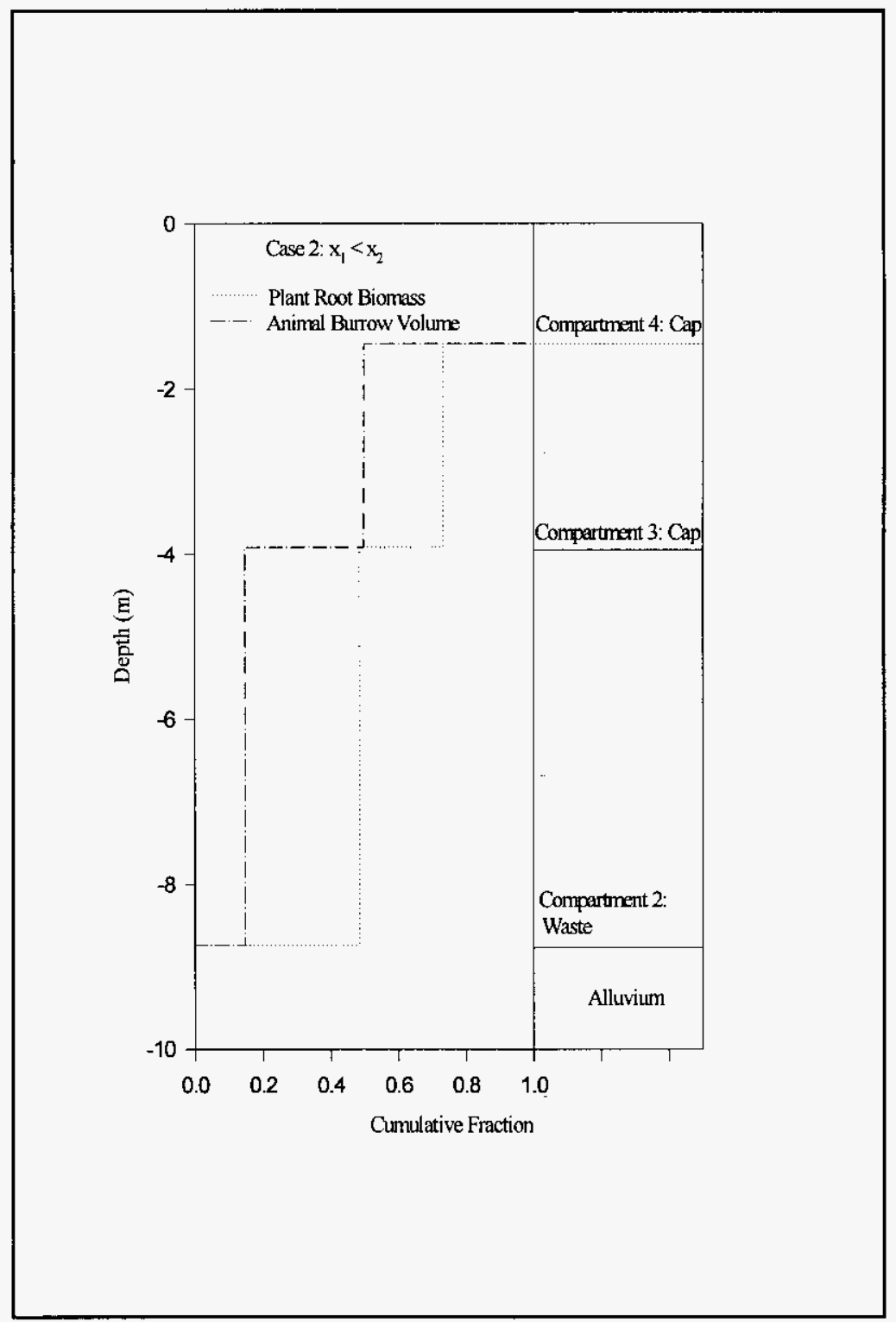

Figure A2.3 Example Realization of Model Case 2.

In Case (3), the maximum rooting depth is assumed to fall within the waste layer. The cap is assigned two compartments: a shallow and deep layer with biological transport. The waste layer is assigned two compartments, an upper compartment with biological transport and a lower one without biological transport (Figure A2.4). 
The initial activity in each compartment is estimated for each of the three cases based on the initial inventory, $\mathrm{I}(0)$, as shown in Table A2.2. The initial inventory is assumed to be lognormally distributed with mean and standard deviation as listed in Table A2.3.

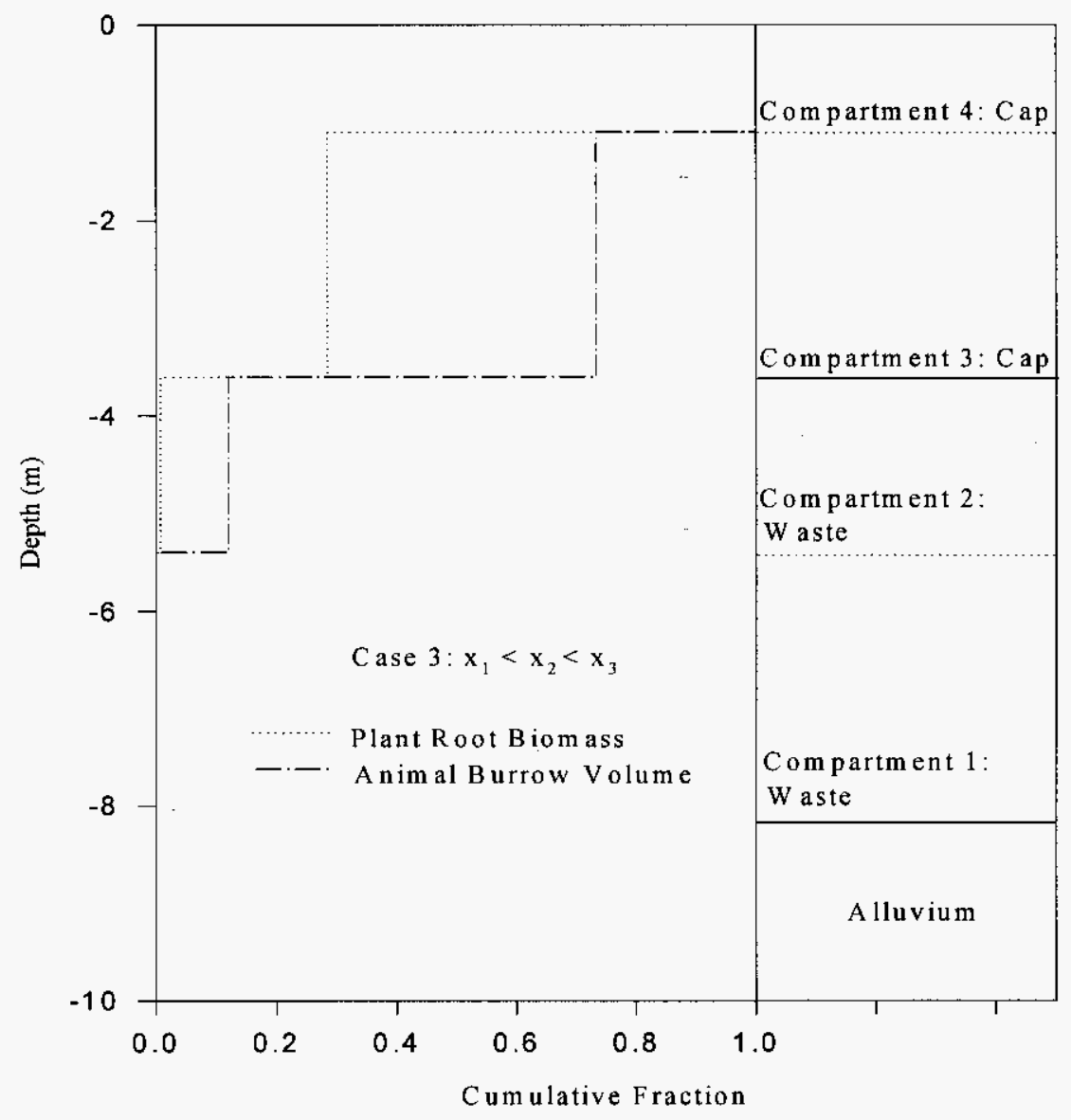

Figure A2.4 Example Realization of Model Case 3. 
Table A2.3 Estimated Inventory of the Area 5 RWMS Shallow Pits and Trenches at Closure in 2028

\begin{tabular}{|c|c|c|c|c|}
\hline Nuclide & Mean (Ci) & $\begin{array}{l}\text { Standard } \\
\text { Deviation }\end{array}$ & Distribution & Source \\
\hline${ }^{3} \mathrm{H}$ & $2.0 \mathrm{e} 6$ & $2.2 \mathrm{e} 6$ & Lognormal & $\begin{array}{l}\text { Development of the pre- } 1988 \text { inventory } \\
\text { estimate is described is Appendix } 1 . \text { The }\end{array}$ \\
\hline${ }^{14} \mathrm{C}$ & $1.4 \mathrm{e} 1$ & $2.4 \mathrm{e} l$ & Lognormal & distributions of nuclide inventories were \\
\hline${ }^{36} \mathrm{Cl}$ & $7.7 e-1$ & $1.2 \mathrm{e} 0$ & Lognormal & $\begin{array}{l}\text { skewed toward lower values and fit to a } \\
\text { lognormal distribution. The estimate of the }\end{array}$ \\
\hline${ }^{39} \mathrm{Ar}$ & $3.8 \mathrm{e} 0$ & $4.6 \mathrm{e} 0$ & Lognormal & $\begin{array}{l}\text { post-1988 inventory is described in Shott } \\
\text { et al. }(1997 \mathrm{a}) . \text { The }{ }^{3} \mathrm{H} \text { inventory is the sum of }\end{array}$ \\
\hline${ }^{40} \mathrm{~K}$ & $1.1 \mathrm{e} 0$ & $1.3 \mathrm{e} 0$ & Lognormal & $\begin{array}{l}\text { the shallow pits and trenches inventory and } \\
\text { the Greater Confinement Disposal (GCD) }\end{array}$ \\
\hline${ }^{85} \mathrm{Kr}$ & $4.6 \mathrm{e} 1$ & $4.7 \mathrm{e} 1$ & Lognormal & inventory. \\
\hline${ }^{90} \mathrm{Sr}$ & $9.0 \mathrm{e} 4$ & $9.8 \mathrm{e} 4$ & Lognormal & \\
\hline${ }^{94} \mathrm{Nb}$ & $6.5 \mathrm{e}-1$ & $9.9 \mathrm{e}-1$ & Lognormal & \\
\hline${ }^{99} \mathrm{Tc}$ & $4.9 \mathrm{e} 2$ & $6.3 \mathrm{e} 2$ & Lognormal & \\
\hline${ }^{126} \mathrm{Sn}$ & $2.4 \mathrm{e}-1$ & $2.9 \mathrm{e}-1$ & Lognormal & \\
\hline${ }^{137} \mathrm{Cs}$ & $1.4 \mathrm{e} 5$ & $1.4 \mathrm{e} 5$ & Lognormal & \\
\hline${ }^{210} \mathrm{~Pb}$ & $3.2 \mathrm{e} 1$ & $7.1 \mathrm{e} 1$ & Lognormal & \\
\hline${ }^{226} \mathrm{Ra}$ & $4.5 \mathrm{el}$ & $1.0 \mathrm{e} 2$ & Lognormal & \\
\hline${ }^{228} \mathrm{Ra}$ & $2.2 \mathrm{e} 0$ & $8.4 \mathrm{e} 0$ & Lognormal & \\
\hline${ }^{227} \mathrm{Ac}$ & $5.7 \mathrm{e}-1$ & $8.6 \mathrm{e}-1$ & Lognormal & \\
\hline${ }^{228} \mathrm{Th}$ & $5.1 \mathrm{e} 0$ & $8.9 \mathrm{e} 0$ & Lognormal & \\
\hline${ }^{229} \mathrm{Th}$ & $4.5 e-3$ & $1.0 \mathrm{e}-2$ & Lognormal & " \\
\hline${ }^{230} \mathrm{Th}$ & $2.3 \mathrm{e} 0$ & $5.2 \mathrm{e} 0$ & Lognormal & \\
\hline${ }^{232} \mathrm{Th}$ & $7.0 \mathrm{e} 0$ & $1.2 \mathrm{e} 1$ & Lognormal & \\
\hline${ }^{231} \mathrm{~Pa}$ & $3.4 \mathrm{e}-1$ & $6.2 \mathrm{e}-1$ & Lognormal & \\
\hline${ }^{233} \mathrm{U}$ & $1.2 \mathrm{e} 0$ & $9.7 e-1$ & Lognormal & \\
\hline${ }^{234} \mathrm{U}$ & $2.7 \mathrm{e} 3$ & $3.6 \mathrm{e} 3$ & Lognormal & \\
\hline${ }^{235} \mathrm{U}$ & $1.7 \mathrm{e} 2$ & $2.0 \mathrm{e} 2$ & Lognormal & \\
\hline${ }^{236} \mathrm{U}$ & $6.1 \mathrm{e} 1$ & $6.9 \mathrm{e} 1$ & Lognormal & \\
\hline${ }^{238} \mathrm{U}$ & $5.7 \mathrm{e} 3$ & $6.9 \mathrm{e} 3$ & Lognormal & \\
\hline${ }^{237} \mathrm{~Np}$ & $6.3 \mathrm{e} 0$ & $4.0 \mathrm{e} 0$ & Lognormal & \\
\hline${ }^{238} \mathrm{Pu}$ & $5.3 \mathrm{e} 2$ & $8.4 \mathrm{e} 2$ & Lognormal & - \\
\hline
\end{tabular}


Table A2.3 (continued)

\begin{tabular}{lcclll}
\hline Nuclide & Mean (Ci) & $\begin{array}{c}\text { Standard } \\
\text { Deviation }\end{array}$ & Distribution & Source \\
\hline${ }^{239} \mathrm{Pu}$ & $6.3 \mathrm{e} 2$ & $6.9 \mathrm{e} 2$ & Lognormal & \\
${ }^{240} \mathrm{Pu}$ & $1.6 \mathrm{e} 2$ & $1.4 \mathrm{e} 2$ & Lognormal & \\
${ }^{241} \mathrm{Pu}$ & $5.0 \mathrm{e} 2$ & $8.0 \mathrm{e} 2$ & Lognormal & \\
${ }^{241} \mathrm{Am}$ & $1.7 \mathrm{e} 2$ & $2.0 \mathrm{e} 2$ & Lognormal \\
\hline
\end{tabular}

\section{A2.1.2 Estimation of First-Order Rate Constants}

The model assumes that the transfer of nonvolatile radionuclides between model compartments can be estimated using first-order rate constants. Rate constants represent the fractional loss of activity per unit time from the source compartment to the receiving compartment. Each constant is estimated as the ratio of the rate of change of the activity in the compartment divided by the total activity in the compartment.

\section{A2.1.2.1 Advective Transport Rate Constants}

The advective transport rate constants (from one compartment to the compartment immediately above) are derived as the upward advective velocity divided by the compartment thickness. The advective velocity is radionuclide-specific, and is derived as the advective liquid flux divided by the retardation factor and the effective pore water content. Combining, the advective rate constants are calculated as:

$$
L_{m, m+1}=\left\{\begin{array}{cc}
v & \text { for } m<3 \\
\frac{\left(d_{m}-d_{m+1}\right)\left(\theta_{v}+\rho_{m} K_{d}\right)}{0} & \text { for } m=3
\end{array}\right.
$$

where

$$
\begin{aligned}
& \mathrm{L}_{\mathrm{m}, \mathrm{m}+1}=\text { advective transport rate constant from compartment } \mathrm{m} \text { to overlying } \\
& \text { compartment } \mathrm{m}+1, \mathrm{yr}^{-1} \text {; } \\
& v \quad=\quad \text { advective liquid flux, } \mathrm{m} / \mathrm{yr} \text {; } \\
& \mathrm{d}_{\mathrm{m}} \quad=\quad \text { depth of compartment } \mathrm{m}, \mathrm{m} \text {; } \\
& \theta_{\mathrm{v}}=\text { volumetric water content biomass, where transport is assumed to } \\
& \text { be upward only, } \mathrm{m}^{3} / \mathrm{m}^{3} \text {; } \\
& \rho_{\mathrm{m}} \quad=\quad \text { bulk density of medium in compartment } \mathrm{m}, \mathrm{g} / \mathrm{cm}^{3} \text {; and } \\
& \mathrm{K}_{\mathrm{d}}=\text { distribution coefficient, } \mathrm{cm}^{3} / \mathrm{g} \text {. }
\end{aligned}
$$


Parameter Selection. There are no direct measurements of the steady-state net upward liquid flux at the site. Chapman $(1995,1997)$ used stable isotope data to estimate the upward liquid flux at the Area 3 and Area 5 RWMSs. The Area 5 RWMS upward flux estimate was revised in 1998 to account for the upward vapor flux (Chapman, 1998). Chapman's (1998) rate estimates for water loss from the vadose zone (including both liquid and vapor) range from 0.11 to 0.55 millimeter (mm)/yr (4e-3 to $2 \mathrm{e}-2 \mathrm{inch}[\mathrm{in}] / \mathrm{yr})$, with a mean of $0.27 \mathrm{~mm} / \mathrm{yr}(1 \mathrm{e}-2 \mathrm{in} / \mathrm{yr})$ and standard deviation of $0.14 \mathrm{~mm} / \mathrm{yr}(5 \mathrm{e}-3 \mathrm{in} / \mathrm{yr})$. The advective flux is treated as a lognormally distributed random variable with the above parameter values in the arithmetic space. Parameter values are listed in Table A2.4.

Table A2.4 Advective Transport Parameters

\begin{tabular}{llll}
\hline \multicolumn{1}{c}{ Parameter } & \multicolumn{1}{c}{ Parameter Values } & Distribution & \multicolumn{1}{c}{ Source } \\
\hline Advective Flux, $\mathrm{v}$ & $\begin{array}{l}\text { Mean: } 2.7 \mathrm{e}-4 \mathrm{~m} / \mathrm{yr} \\
\text { Stand. Dev.: } 1.4 \mathrm{e}-4 \mathrm{~m} / \mathrm{yr}\end{array}$ & Lognormal & $\begin{array}{l}\text { Chapman's (1995) corrected } \\
\text { estimate of long-term flux } \\
\text { including liquid and vapor flux. }\end{array}$ \\
$\begin{array}{l}\text { Volumetric Water } \\
\text { Content, } \theta_{\mathrm{v}}\end{array}$ & 0.18 & Fixed & $\begin{array}{l}\text { Conservative value for moist } \\
\text { alluvium based on observations of } \\
\end{array}$ \\
& & $\begin{array}{l}\text { subsidence craters receiving run- } \\
\text { on. }\end{array}$ \\
\hline
\end{tabular}

The radionuclide retardation factor is computed from bulk density, volumetric pore water content $(0.18)$, and a radionuclide-specific distribution coefficient, assuming that radionuclides partition between water and solids linearly. The bulk density of alluvium or waste is used depending on the compartment contents. The distribution coefficients are from data for sand reported by $\mathrm{Yu}$ et al. (1993) and are shown in Table A2.5.

\section{A2.1.2.2 Burrowing Animal Rate Constants}

The rate of removal of activity from a given compartment by animal burrowing is assumed to be proportional to the rate of burrow excavation. The constant of proportionality is the fraction of burrow volume in the compartment. The distribution of burrow volume with depth is poorly known and is likely to vary with species. The volume of invertebrate burrows is assumed to be distributed uniformly with depth. In general, the fraction of burrow volume in a compartment is then:

$$
f_{b m}= \begin{cases}\frac{d_{m}-d_{m+1}}{x_{2}} & \text { for } d_{m} \leq x_{2} \\ 0 & \text { for } d_{m}>x_{2}\end{cases}
$$


Table A2.5 Geometric Mean Distribution Coefficients for Sandy Soil Type (from Yu et al., 1993)

\begin{tabular}{cc|cc}
\hline Element & $\begin{array}{c}\text { Distribution Coefficient } \\
\left(\mathbf{m}^{3} / \mathbf{k g}\right)\end{array}$ & Element & $\begin{array}{c}\text { Distribution Coefficient } \\
\left(\mathbf{m}^{3} / \mathbf{k g}\right)\end{array}$ \\
\hline $\mathrm{H}$ & 0 & $\mathrm{Cs}$ & 0.28 \\
$\mathrm{C}$ & 0.005 & $\mathrm{Sm}$ & 0.245 \\
$\mathrm{Cl}$ & 0.0017 & $\mathrm{Eu}$ & 0.24 \\
$\mathrm{~K}$ & 0.015 & $\mathrm{Gd}$ & 0.24 \\
$\mathrm{Ca}$ & 0.005 & $\mathrm{Ho}$ & 0.25 \\
$\mathrm{Co}$ & 0.06 & $\mathrm{~Pb}$ & 0.27 \\
$\mathrm{Ni}$ & 0.4 & $\mathrm{Ra}$ & 0.5 \\
$\mathrm{Sr}$ & $\mathrm{Ac}$ & 0.45 \\
$\mathrm{Zr}$ & 0.015 & $\mathrm{Th}$ & 3.2 \\
$\mathrm{Nb}$ & 0.6 & $\mathrm{~Pa}$ & 3.2 \\
$\mathrm{Tc}$ & 0.16 & $\mathrm{U}$ & 0.035 \\
$\mathrm{Pd}$ & 0.0001 & $\mathrm{~Np}$ & 0.005 \\
$\mathrm{Cd}$ & 0.055 & $\mathrm{Pu}$ & 0.55 \\
$\mathrm{Sn}$ & 0.08 & $\mathrm{Am}$ & 1.9 \\
$\mathrm{I}$ & 0.13 & $\mathrm{Cm}$ & 4 \\
\hline
\end{tabular}

where

$\begin{array}{lll}\mathrm{f}_{\mathrm{bm}} & = & \text { fraction of burrow volume in compartment } \mathrm{m} \text {, dimensionless; } \\ \mathrm{d}_{\mathrm{m}} & = & \text { depth of compartment } \mathrm{m}, \mathrm{m} ; \text { and } \\ \mathrm{x}_{2} & = & \text { maximum depth of biological activity, } \mathrm{m} .\end{array}$

The excavated material is assumed to be distributed proportionally among the overlying compartments based on the thickness of each compartment. In general, the rate of removal of activity from a compartment, $\mathrm{m}$, to an overlying compartment, $\mathrm{n}$, attributable to burrowing animal transport to shallow soils is calculated as:

$$
\frac{d A_{m, j}}{d t}=\frac{C_{m, j} M_{b} D_{b} A f_{b m}}{\rho_{m}} \frac{\left(d_{n}-d_{n+1}\right)}{d_{m+1}}
$$


and the activity in compartment $\mathrm{m}$ is given by:

$$
A_{m, j}=C_{m, j} V_{m}
$$

where

$\begin{array}{lll}\mathrm{A}_{\mathrm{m}, \mathrm{j}} & = & \text { activity of radionuclide } \mathrm{j} \text { in compartment } \mathrm{m}, \mathrm{Ci} \\ \mathrm{C}_{\mathrm{m}, \mathrm{j}} & = & \text { radionuclide } \mathrm{j} \text { concentration in compartment } \mathrm{m}, \mathrm{Ci} / \mathrm{m}^{3} ; \\ \mathrm{M}_{\mathrm{b}} & = & \text { burrow excavation rate, } \mathrm{g} /(\text { colony } \mathrm{yr}) \\ \mathrm{D}_{\mathrm{b}} & = & \text { colony density, colony } / \mathrm{m}^{2} ; \\ \mathrm{A} & = & \text { disposal unit area, } \mathrm{m}^{2} ; \text { and } \\ \mathrm{V}_{\mathrm{m}} & = & \text { volume of compartment } \mathrm{m}, \mathrm{m}^{3} .\end{array}$

Dividing Equation A2.4 with Equation A2.5 and substituting Equation A2.3 for $\mathrm{f}_{\mathrm{bm}}$ gives the general burrowing animal rate constant for transfer from a compartment to any overlying compartment as:

$$
B_{m, n}=\left\{\begin{array}{cl}
\frac{M_{b} D_{b}}{\rho_{m} x_{2}} \frac{d_{n}-d_{n+1}}{d_{m+1}} & \text { for } d_{m} \leq x_{2} \\
0 & \text { for } d_{m}>x_{2}
\end{array}\right.
$$

where

$$
\begin{aligned}
& \mathrm{B}_{\mathrm{m}, \mathrm{n}}=\quad \begin{array}{l}
\text { the burrowing animal transfer rate constant for transfer from } \\
\text { compartment } \mathrm{m} \text { to compartment } \mathrm{n}, \mathrm{yr}^{-1} \text {. }
\end{array}
\end{aligned}
$$

Considering where the depth of biological activity falls relative to the cap thickness, the burrowing animal rate constants for the three cases become:

$$
B_{2,4}=\left\{\begin{aligned}
0 & \text { for Case 1: } x_{2} \leq x_{3} \\
\frac{M_{b} D_{b} d_{4}}{\rho_{w} x_{2} d_{3}} & \text { for Cases } 2 \text { and } 3: x_{2}>x_{3}
\end{aligned}\right.
$$




$$
B_{2,3}=\left\{\begin{array}{cc}
0 & \text { for Case 1: } x_{2} \leq x_{3} \\
\frac{M_{b} D_{b}\left(d_{3}-d_{4}\right)}{\rho_{w} x_{2} d_{3}} & \text { for Cases } 2 \text { and } 3: x_{2}>x_{3}
\end{array}\right.
$$

and for Cases 1 through 3:

$$
B_{3,4}=\frac{M_{b} D_{b}}{\rho_{s} x_{2}} \text { for all cases }
$$

where

$$
\begin{array}{lll}
\rho_{\mathrm{w}} & = & \text { waste bulk density, } \mathrm{g} / \mathrm{m}^{3} ; \text { and } \\
\rho_{\mathrm{s}} & = & \text { soil bulk density, } \mathrm{g} / \mathrm{m}^{3} .
\end{array}
$$

Parameter Selection. The burrowing animal rate constants are estimated using Equations A2.7 through A2.9. All input parameters are random variables (Tables A2.1 and A2.6). It is assumed that only invertebrates burrow below the depth of the shallow surface layer. Invertebrate burrow depth corresponds approximately with maximum plant rooting depths (Fitzner et al., 1979; and Cline et al., 1980). Site-specific data are not available for the burrow excavation rate and colony density. Parameter values are estimated from several studies of ants and termites in arid sites in the western United States (Fitzner et al., 1979; Whitford et al., 1982; Nutting et al., 1985; Blom et al., 1991). The termite data are used to estimate the upper limit excavation rates, which are considered extremely conservative.

\section{A2.1.2.3 Plant Uptake Rate Constants}

The plant uptake rate constant assumes that the rate of removal of activity from a compartment by plant growth and senescence is proportional to biomass production. The proportionality constant is the product of the plant-soil concentration ratio and the mass fraction of plant roots in the source compartment. The activity removed is proportionally divided among the receiving compartments based on the mass fraction of production occurring in each compartment. The surface compartment receives all aboveground production and underground production occurring in this compartment. 
The density of plant roots is observed to decline rapidly with depth at arid sites (Tabler, 1964; Sturges, 1977; Wallace et al., 1980; Foxx et al., 1984; Klepper et al., 1985; Link et al., 1994). The upper few centimeters of soil may have reduced root density because of high temperatures and low water content. Below a few centimeters, plant root density rapidly peaks and then decreases rapidly. The distribution with depth varies with species and location, but can be reasonably represented by an exponentially decreasing function. Assuming root biomass decreases exponentially with depth, the fractional biomass present in any compartment is:

$$
f_{r m}=\left\{\begin{array}{cc}
\frac{e^{-\beta d_{m+1}}-e^{-\beta d_{m}}}{1-e^{-\beta x_{2}}} \text { for } d_{m} \leq x_{2} \\
0 \quad \text { for } d_{m}>x_{2}
\end{array}\right.
$$

where

$$
\begin{array}{lll}
\mathrm{f}_{\mathrm{rm}} & = & \text { mass fraction of root biomass in compartment } \mathrm{m}, \text { dimensionless; } \\
\beta & = & \text { and } \\
\beta & \text { inverse biological transport length, } \mathrm{m}^{-1} .
\end{array}
$$

The inverse biological transport length is estimated assuming the depth of the biological transport region, $x_{2}$, includes 99 percent of the root biomass. The inverse biological transport length is then estimated as:

$$
\beta=\frac{-\ln 0.01}{x_{2}}
$$

In general, the rate of change of activity in a compartment, $\mathrm{m}$, due to plants transferring activity to the surface compartment, $\mathrm{n}$, is given by:

$$
\frac{d A_{m, j}}{d t}=\frac{C_{m, j} B_{j, v} B_{p} A f_{r m}}{\rho_{m}}\left(1+f_{r m} B_{r s}\right)
$$

where

$$
\begin{aligned}
& \mathrm{B}_{\mathrm{j}, \mathrm{v}}=\text { plant-soil concentration ratio for radionuclide } \mathrm{j}, \mathrm{pCi} / \mathrm{g} \text { dry plant per } \\
& \mathrm{pCi} / \mathrm{g} \text { dry soil; } \\
& \mathrm{B}_{\mathrm{p}} \quad=\quad \text { net annual aboveground primary production, } \mathrm{g} /\left(\mathrm{m}^{2} \mathrm{yr}\right)(\mathrm{dry}) ;
\end{aligned}
$$


$\mathrm{f}_{\mathrm{rm}}=$ fraction of root biomass in source compartment $\mathrm{m}$, dimensionless;

$\mathrm{f}_{\mathrm{rn}} \quad=\quad$ fraction of root biomass in receiving compartment $\mathrm{n}$; and

$\mathrm{B}_{\mathrm{rs}}=$ ratio of underground to aboveground primary production, $\mathrm{g} /\left(\mathrm{m}^{2} \mathrm{yr}\right)$ underground per $\mathrm{g} /\left(\mathrm{m}^{2} \mathrm{yr}\right)$ aboveground.

Because subsurface compartments do not receive aboveground production, the general expression for the derivative in subsurface compartments becomes:

$$
\frac{d A_{m, j}}{d t}=\frac{C_{m, j} B_{j, v} B_{p} A f_{r m} f_{r n} B_{r s}}{\rho_{m}}
$$

Dividing Equations A2.12 and A2.13 by the expression for compartment volume, general expressions for the root uptake rate constants are obtained as:

$$
R_{m, n}=\left\{\begin{array}{cl}
\frac{B_{j, v} B_{p} f_{r m}}{\left(d_{m}-d_{m+1}\right) \rho_{m}}\left(1+f_{r n} B_{r s}\right) & \text { for } d_{m} \leq x_{2} \text { and } n=4 \\
\frac{B_{j, v} B_{p} f_{r m} f_{r m} B_{r s}}{\left(d_{m}-d_{m+1}\right) \rho_{m}} & \text { for } d_{m} \leq x_{2} \text { and } n \neq 4 \\
0 & \text { for } d_{m}>x_{2}
\end{array}\right.
$$

Considering the depth of biological activity relative to the cap and waste thickness, the plant root uptake rate constants for a four compartment model become:

$$
R_{2,4}=\left\{\begin{array}{c}
0 \quad \text { for Case } 1: x_{2} \leq x_{3} \\
\frac{B_{j, v} B_{p}\left(e^{-\beta d_{3}}-e^{-\beta d_{2}}\right)}{\left(d_{2}-d_{3}\right) \rho_{w}\left(1-e^{-\beta x_{2}}\right)}\left[1+B_{r s} \frac{\left(1-e^{-\beta d_{4}}\right)}{\left(1-e^{-\beta x_{2}}\right)}\right] \text { for Cases } 2 \text { and } 3: x_{2}>x_{3}
\end{array}\right.
$$




$$
R_{2,3}=\left\{\begin{array}{c}
0 \quad \text { for Case } 1: x_{2} \leq x_{3} \\
\frac{B_{j, v} B_{p}\left(e^{-\beta d_{3}}-e^{-\beta d_{2}}\right)\left(e^{-\beta d_{4}}-e^{-\beta d_{3}}\right) B_{r s}}{\left(d_{2}-d_{3}\right) \rho_{w}\left(1-e^{-\beta x_{2}}\right)^{2}} \text { for Cases } 2 \text { and } 3: x_{2}>x_{3}
\end{array}\right.
$$

and

$$
R_{3,4}=\frac{B_{j, v} B_{p}\left(e^{-\beta d_{4}}-e^{-\beta d_{3}}\right)}{\left(d_{3}-d_{4}\right) \rho_{w}\left(1-e^{-\beta x_{2}}\right)}\left[1+B_{r s} \frac{\left(1-e^{-\beta d_{4}}\right)}{\left(1-e^{-\beta x_{2}}\right)}\right] \text { for Case 2: } x_{2} \geq x_{1}
$$

where

$$
\begin{array}{lll}
\mathrm{R}_{2,4} & = & \begin{array}{l}
\text { root uptake rate constant for transfer from compartment (2) to } \\
\text { compartment }(4), \mathrm{yr}^{-1} ;
\end{array} \\
\mathrm{R}_{2,3} & = & \begin{array}{l}
\text { root uptake rate constant for transfer from compartment (2) to } \\
\text { compartment }(3), \mathrm{yr}^{-1} \text {; and }
\end{array} \\
\mathrm{R}_{3,4} & = & \begin{array}{l}
\text { root uptake rate constant for transfer from compartment (3) to } \\
\text { compartment (4), } \mathrm{yr}^{-1} .
\end{array}
\end{array}
$$

Parameter Selection. The root uptake rate constants are estimated using Equations A2.15 through A2.17. All input parameters are random variables (Tables A2.7 and A2.8). All data were selected to represent disposal units at the Area 5 RWMS under current biotic and climatic conditions.

The aboveground primary productivity was estimated from values reported in the literature for arid sites, including several sites on the NTS. The primary productivity data are assumed to be lognormally distributed because the data are skewed toward lower values. The mean of the data was $63 \mathrm{~g} /\left(\mathrm{m}^{2} \mathrm{yr}\right)$ and the standard deviation $38 \mathrm{~g} /\left(\mathrm{m}^{2} \mathrm{yr}\right)$. The root-to-shoot production ratio is based on literature values of the root/shoot biomass ratio for mature plants in arid environments. Again, the data are skewed and a lognormal distribution is assumed. The root-to-shoot production ratio has a mean of 1.5 and standard deviation of 1.4 .

The selected plant-soil concentration ratios are geometric means derived from the International Union of Radioecologists' data set by Kennedy and Strenge (1992). The geometric mean value was calculated using the geometric mean for root, fruit, and grain data. The data required are plant-soil concentration ratios for root uptake. The plant-soil concentration ratios for leafy 


\begin{tabular}{|c|c|c|c|}
\hline Parameter & Parameter Values & Distribution & Source \\
\hline $\begin{array}{l}\text { Aboveground Primary } \\
\text { Productivity, } B_{p}\end{array}$ & $\begin{array}{l}\text { Mean: } 63 \mathrm{~g} /\left(\mathrm{m}^{2} \mathrm{yr}\right) \\
\text { Stand. Dev.: } 38 \mathrm{~g} /\left(\mathrm{m}^{2} \mathrm{yr}\right)\end{array}$ & Lognormal & $\begin{array}{l}\text { The aboveground primary productivity data are from the } \\
\text { literature for arid sites including the NTS (Chew and Chew, } \\
1965 \text {; Wallace and Romney, 1972; Bamberg } \text { et al. } 1976 \text {; } \\
\text { Caldwell et al., 1977; Strojan et al. 1979; Turner and } \\
\text { Randall, 1989). The data are skewed toward lower values. } \\
\text { The data were fit to a lognormal distribution with a mean } \\
\text { of } 63 \mathrm{~g} /\left(\mathrm{m}^{2} \mathrm{yr}\right) \text { and a standard deviation of } 38 \\
(\text { Kolmogorov-Smirnov Goodness of Fit Test } \mathrm{D}=0.13, \mathrm{p}= \\
0.40, \mathrm{n}=26) \text {. The lower limit of the distribution was set to } \\
\text { zero. }\end{array}$ \\
\hline $\begin{array}{l}\text { Root-to-Shoot Production } \\
\text { Ratio, } B_{\mathrm{rb}}\end{array}$ & $\begin{array}{l}\text { Mean: } 1.5 \\
\text { Stand. Dev.: } 1.4\end{array}$ & Lognormal & $\begin{array}{l}\text { The ratio of root-to-shoot production data are derived from } \\
\text { the ratio of root biomass to shoot biomass. The data set is } \\
\text { obtained from the literature for mature plants in arid } \\
\text { environments (Wallace and Romney, 1972; Barbour, } 1973 \text {; } \\
\text { Wallace et al. 1974). The data were fit to a lognormal } \\
\text { distribution with a mean of } 1.5 \text { and a standard deviation of } \\
1.4 \text { (Kolmogorov-Smirnov Goodness of Fit } \mathrm{D}=0.09, \mathrm{p}= \\
0.54, \mathrm{n}=57 \text { ). The lower limit of the distribution was set to } \\
\text { zero. }\end{array}$ \\
\hline
\end{tabular}




\begin{tabular}{|c|c|c|c|c|c|}
\hline \multirow[b]{2}{*}{ Element } & \multicolumn{4}{|c|}{ Concentration Ratio, $\mathbf{B}_{\mathrm{j}, \mathrm{v}}$} & \multirow[b]{2}{*}{ Source } \\
\hline & $\begin{array}{c}\text { Arithmetic } \\
\text { Mean }\end{array}$ & $\begin{array}{l}\text { Standard } \\
\text { Deviation }\end{array}$ & Distribution & Units & \\
\hline $\mathrm{C}$ & $3.2 \mathrm{e} 0$ & $1.4 \mathrm{e} 1$ & lognormal & $\mathrm{pCi} / \mathrm{g}$ dry plant per $\mathrm{pCi} / \mathrm{g}$ dry soil & \multirow{17}{*}{$\begin{array}{l}\text { The plant-soil concentration ratios are assumed to } \\
\text { be lognormally distributed based on previous reports } \\
\text { (Ng et al., 1982; NCRP, 1984; Sheppard and } \\
\text { Evenden, 1997). The mean value is derived from } \\
\text { the International Union of Radioecologists' } \\
\text { compilation as reported by Kennedy and Strenge } \\
\text { (1992). The arithmetic mean is calculated from the } \\
\text { geometric mean of the root, fruit, and grain } \\
\text { geometric means reported by Kennedy and Strenge } \\
\text { (1992). The arithmetic standard deviation is based } \\
\text { on an assumed geometric standard deviation of } 5.7 \\
\text { as recommended by Sheppard and Evenden (1997) } \\
\text { for nonspecific plants and soil conditions. } \\
\text { Plutonium and americium data are based on root } \\
\text { uptake experiments conducted with contaminated } \\
\text { NTS soil (Au et al., } 1977 ; \text { Romney } \text { et al., 1982). } \\
\text { The Pu data were fit to a lognormal distribution } \\
\text { (Kolmogorov-Smirnov D }=0.12, \mathrm{p}=0.11, \mathrm{n}=77 \text { ). } \\
\text { The Am data were fit to a lognormal distribution } \\
\text { (Kolmogorov-Smirnov D =0.069, } \mathrm{p}=0.48, \mathrm{n}=77 \text { ). }\end{array}$} \\
\hline $\mathrm{Cl}$ & $3.2 \mathrm{e} 2$ & $1.4 \mathrm{e} 3$ & lognormal & $\mathrm{pCi} / \mathrm{g}$ dry plant per $\mathrm{pCi} / \mathrm{g}$ dry soil & \\
\hline $\mathrm{K}$ & $2.5 \mathrm{e} 0$ & $1.1 \mathrm{el}$ & lognormal & $\mathrm{pCi} / \mathrm{g}$ dry plant per $\mathrm{pCi} / \mathrm{g}$ dry soil & \\
\hline $\mathrm{Ca}$ & $1.6 \mathrm{e} 0$ & $7.1 \mathrm{e} 0$ & lognormal & pCi/g dry plant per pCi/g dry soil & \\
\hline $\mathrm{Sr}$ & $1.2 \mathrm{e} 0$ & $5.3 \mathrm{e} 0$ & lognormal & $\mathrm{pCi} / \mathrm{g}$ dry plant per $\mathrm{pCi} / \mathrm{g}$ dry soil & \\
\hline $\mathrm{Nb}$ & $2.2 \mathrm{e}-2$ & $1.0 \mathrm{E}-1$ & lognormal & $\mathrm{pCi} / \mathrm{g}$ dry plant per $\mathrm{pCi} / \mathrm{g}$ dry soil & \\
\hline $\mathrm{Tc}$ & $4.8 \mathrm{e} 0$ & $2.1 \mathrm{e} 1$ & lognormal & $\mathrm{pCi} / \mathrm{g}$ dry plant per $\mathrm{pCi} / \mathrm{g}$ dry soil & \\
\hline Sn & $2.7 \mathrm{e}-2$ & $1.2 \mathrm{e}-1$ & lognormal & $\mathrm{pCi} / \mathrm{g}$ dry plant per $\mathrm{pCi} / \mathrm{g}$ dry soil & \\
\hline Cs & $3.0 \mathrm{e}-1$ & $1.3 \mathrm{e} 0$ & lognormal & pCi/g dry plant per pCi/g dry soil & \\
\hline $\mathrm{Pb}$ & $2.3 \mathrm{e}-2$ & $1.0 \mathrm{e}-1$ & lognormal & $\mathrm{pCi} / \mathrm{g}$ dry plant per $\mathrm{pCi} / \mathrm{g}$ dry soil & \\
\hline $\mathrm{Ra}$ & $1.3 \mathrm{e}-2$ & $5.8 \mathrm{e}-2$ & lognormal & $\mathrm{pCi} / \mathrm{g}$ dry plant per $\mathrm{pCi} / \mathrm{g}$ dry soil & \\
\hline Ac & $1.6 \mathrm{e}-3$ & $7.1 e-3$ & lognormal & $\mathrm{pCi} / \mathrm{g}$ dry plant per $\mathrm{pCi} / \mathrm{g}$ dry soil & \\
\hline $\mathrm{Pa}$ & $1.1 \mathrm{e}-3$ & $5.0 \mathrm{e}-3$ & lognormal & $\mathrm{pCi} / \mathrm{g}$ dry plant per $\mathrm{pCi} / \mathrm{g}$ dry soil & \\
\hline Th & $3.2 \mathrm{e}-4$ & $1.4 \mathrm{e}-3$ & lognormal & $\mathrm{pCi} / \mathrm{g}$ dry plant per $\mathrm{pCi} / \mathrm{g}$ dry soil & \\
\hline $\mathrm{U}$ & $1.9 \mathrm{e}-2$ & $8.4 \mathrm{e}-2$ & lognormal & $\mathrm{pCi} / \mathrm{g}$ dry plant per $\mathrm{pCi} / \mathrm{g}$ dry soil & \\
\hline $\mathrm{Pu}$ & $6.2 e-3$ & $1.1 \mathrm{e}-1$ & lognormal & $\mathrm{pCi} / \mathrm{g}$ dry plant per $\mathrm{pCi} / \mathrm{g}$ dry soil & \\
\hline $\mathrm{Np}$ & $2.9 \mathrm{e}-2$ & $1.3 e-1$ & lognormal & $\mathrm{pCi} / \mathrm{g}$ dry plant per $\mathrm{pCi} / \mathrm{g}$ dry soil & \\
\hline
\end{tabular}


vegetables were not used because they are expected to include a large contribution from foliar absorption. The data were assumed to be lognormally distributed based on previous reports $(\mathrm{Ng}$ et al., 1982; National Council on Radiation Protection [NCRP], 1984; Sheppard and Evenden, 1997). Because it is unknown how well these data represent plant species and soil conditions at the Area 5 RWMS, a geometric standard deviation of 5.7 was selected based on the recommendations of Sheppard and Evenden (1997). Plutonium and americium (Am) plant-soil concentration ratios were derived from NTS experiments designed to measure root uptake (Au et al., 1977; Romney et al., 1982).

\section{A2.1.2.4 Resuspension Rates}

Radionuclides transported to the shallow soil compartment are lost by resuspension and radioactive decay. Resuspension rates have been estimated for nuclear weapon testing sites and safety test sites on the NTS (Shinn and Homan, 1985; Shinn et al., 1986). The resuspension rates for nonnuclear sites are assumed for the Area 5 RWMS because these best represent the contamination expected to be released from the disposal units. At the nuclear sites, radioactivity may be fused into large silicate glass particulates that are not readily resuspended. Resuspension rates at nonnuclear sites have been reported to range from $8 \mathrm{e}-5$ to $1 \mathrm{e}-2 \mathrm{yr}^{-1}$ (Anspaugh et al., 1975; Shinn et al., 1986). The mean value for the two studies is estimated to be $4 \mathrm{e}-4 \mathrm{yr}^{-1}$. The soil resuspension rate was assumed to be uniformly distributed from $8 \mathrm{e}-5$ to $1 \mathrm{e}-2 \mathrm{yr}^{-1}$.

The NTS resuspension rates are calculated by dividing the measured plutonium aerosol flux by the plutonium soil activity per unit area. The plutonium soil activity per unit area is calculated assuming a 5-centimeter (cm)- (2-inch [in])-thick uniformly distributed soil contamination layer (Shinn and Homan, 1985; Shinn et al., 1986). The depth of the surface soil compartment in the nonvolatile radionuclide release model varies randomly. Therefore, the resuspension rates must be corrected for the changing depth of the surface layer selected in each realization. The NTS resuspension rates are corrected by multiplying by the ratio of the depth used to estimate NTS resuspension, $0.05 \mathrm{~m}$ ( 2 in), to the depth selected for the given realization or $0.05 \mathrm{~m} / \mathrm{d}_{4}$.

\section{A2.1.2.5 Soil Concentration and Surface Emission Rates}

The estimated activity in each compartment is converted into a soil concentration. The soil concentration in the surface soil compartment is obtained by dividing the activity by the mass of soil in the compartment as:

$$
C_{s, j}(t)=\frac{A_{m, j}(t)}{A\left(d_{m}-d_{m+1}\right) \rho_{s}}
$$


where

$$
\begin{aligned}
& \mathrm{C}_{\mathrm{s}, \mathrm{j}}(\mathrm{t})=\quad \begin{array}{l}
\text { activity concentration of radionuclide } \mathrm{j} \text { in the surface soil } \\
\text { compartment, } \mathrm{Ci} / \mathrm{g} \text {. }
\end{array}
\end{aligned}
$$

The surface soil concentration is used to estimate the total effective dose equivalent (TEDE) to individuals living at the Area 5 RWMS and the emission rate to the atmosphere.

The emission rate of radionuclides from the surface soil compartment was estimated using the resuspension factors as:

$$
Q_{s, j}(t)=\frac{A_{m, j}(t) r(0.05 \text { meters })}{A d_{4}}
$$

where

$$
\begin{array}{lll}
\mathrm{Q}_{\mathrm{s}, \mathrm{j}}(\mathrm{t}) & = & \text { surface soil emission rate of radionuclide } \mathrm{j}, \mathrm{Ci} /\left(\mathrm{m}^{2} \mathrm{yr}\right) ; \text { and } \\
\mathrm{r} & = & \text { resuspension rate for } 0.05-\mathrm{m} \text { contamination layer, } \mathrm{yr}^{-1}
\end{array}
$$

The surface soil emission rate is used to estimate airborne radionuclide concentrations and deposition rates at off-site locations.

\section{A2.1.3 Model Implementation}

A FORTRAN computer code was developed to solve the differential equations described in Equation A2.1, and to perform Monte Carlo simulation of the transfer rate constants. The input parameters include a seed number for the random number generator, the number of parameters with input probability distributions, the number of Monte Carlo simulations to be performed, the number of years of the simulation, and the time step for the simulation. The model selects random parameter values from statistical distributions, dimensions the model compartments, and calculates the transfer rate constants.

The code uses a fourth-order Runge-Kutta method to solve the differential equations. The radioactive decay chains were shortened to simplify the numerical solution. Progeny with halflives less than one year and a long-lived parent are assumed to be in equilibrium with the parent. Mass balance expressions were written and solved only for the long-lived parents. The decay chains can have more than one parent feeding the chain. These cases were run as two independent chains and the results summed. An exception was the $4 n+2$ chain originating from ${ }^{238} U$ and ${ }^{238} \mathrm{Pu}$. The progeny activity produced by decay of ${ }^{238} \mathrm{Pu}$ is negligible compared to the progeny from ${ }^{238} \mathrm{U}$ and can be ignored. 
The code converts the radionuclide concentrations in the upper soil compartment into TEDE using scenario dose conversion factors (SDCFs) described in Appendix 3. The SDCFs give the dose per unit concentration of the long-lived parent plus the dose from any short-lived progeny assumed to be in equilibrium. The mean and 95 th percentile of the soil concentrations, surface soil emissions, and TEDE at the Area 5 RWMS were estimated from 1,000 Monte Carlo simulations. The off-site airborne concentration and soil deposition rates were estimated with the Industrial Source Code Long-Term (ISCLT) as described in Section A2.3.

\section{A2.2 Release of Volatile Radionuclides}

The release of volatile radionuclides is assumed to occur by gaseous diffusion through the air-filled pore space of the waste and cap. The gaseous diffusion model used to estimate volatile radionuclide release makes the following assumptions.

- The radionuclide inventory is homogeneously distributed throughout the waste.

- Gaseous radionuclides are immediately and completely released from the waste form to the air-filled pore space. The release of tritiated water (HTO) is limited by the vapor pressure of water in the pore space.

- The soil pore gas concentration at the waste-cap interface is equal to the concentration in the air-filled waste pore space. The gas concentration in the air-filled waste pore space decreases over time by radioactive decay. All radioactive gases decay to stable nuclides.

- Gases are transported through the air-filled pore spaces of the cap and cracks in the cap by gaseous diffusion.

- Diffusion is assumed to be retarded by the tortuous path and water content of the porous medium.

- The gas concentration at the cap-atmosphere interface is zero.

- Tritium releases may be enhanced by plant transpiration.

- Steady-state conditions exist in the waste and cap.

- There are no gas sources in the cap. Gases are lost in the cap by radioactive decay.

The flux density at the cap-air interface is calculated as:

$$
J_{j}(z, t)=-D_{e, j} \varepsilon_{c} \frac{\partial C_{g j}(z, t)}{\partial z}
$$

where

$$
\begin{aligned}
& \mathrm{J}_{\mathrm{j}}(\mathrm{z}, \mathrm{t})=\text { the flux density of radionuclide } \mathrm{j} \text { per unit area of the bulk medium, } \\
& \mathrm{Ci} /\left(\mathrm{m}^{2} \mathrm{yr}\right) \text {; } \\
& \mathrm{D}_{\mathrm{e}, \mathrm{j}}=\text { effective gas diffusion coefficient of radionuclide } \mathrm{j} \text { in the porous } \\
& \text { medium, } \mathrm{m}^{2} / \mathrm{yr} \text {; } \\
& \varepsilon_{c} \quad=\quad \text { air-filled cap porosity, } \mathrm{m}^{3} / \mathrm{m}^{3} ; \text { and } \\
& \mathrm{C}_{\mathrm{g}, \mathrm{j}}=\text { gas concentration in pore gas of radionuclide } \mathrm{j}, \mathrm{Ci} / \mathrm{m}^{3} \text {. }
\end{aligned}
$$


The effective diffusion coefficient is defined after Culot et al. (1976) as the diffusion coefficient corrected for the effects of increased path length in the porous medium. Consistent with the above definition, the effective gas diffusion coefficient is calculated as (Jury et al., 1991):

$$
D_{e, j}=D_{a, j} \varepsilon_{c}^{0.33}(1-S)^{2}
$$

where

$$
\begin{array}{ll}
\mathrm{D}_{\mathrm{a}, \mathrm{j}} & =\text { diffusion coefficient in free air of radionuclide } \mathrm{j}, \mathrm{m}^{2} / \mathrm{yr} \text {; and } \\
\mathrm{S} & =
\end{array}
$$

The concentration profile in the cap is obtained from an analytical solution to a one-dimensional mass balance expression considering gaseous diffusion and radioactive decay. The equation of continuity for a radioactive gas without a radioactive parent diffusing through a closure cap is given as:

$$
\frac{\partial C_{g, j}(z, t)}{\partial t}=D_{e, j} \frac{\partial^{2} C_{g, j}(z, t)}{\partial z^{2}}-\lambda_{j} C_{g, j}(z, t)
$$

where

$$
\lambda_{\mathrm{j}}=\text { radioactive decay constant of radionuclide } \mathrm{j}, \mathrm{yr}^{-1} .
$$

The equation of continuity is solved assuming steady-state conditions and two boundary conditions. Gaseous radionuclides are assumed to be completely and immediately released to the pore space and to be lost only by radioactive decay. This gives the maximum release that could occur by diffusion at any time. The assumed boundary conditions can be written as:

$$
\begin{gathered}
C_{g, j}(0, t)=C_{g, j}(0,0) e^{-\lambda_{j} t} \\
C_{g, j}(x, t)=0
\end{gathered}
$$


where

$$
\begin{array}{lll}
\mathrm{C}_{\mathrm{g}, \mathrm{j}}(0,0) & = & \text { initial pore gas concentration in the waste of radionuclide } \mathrm{j}, \mathrm{Ci} / \mathrm{m}^{3} \\
\mathrm{C}_{\mathrm{g}, \mathrm{j}}(\mathrm{x}, \mathrm{t}) & = & \text { soil pore gas concentration at cap-air interface }(\mathrm{z}=\mathrm{x}), \mathrm{Ci} / \mathrm{m}^{3} ; \\
\mathrm{x} & =\quad \text { cap thickness, } \mathrm{m} ; \text { and } \\
\mathrm{t} & =\quad \text { elapsed time since closure, } \mathrm{yr} .
\end{array}
$$

With the assumptions above, a particular solution can be obtained as:

$$
C_{g, j}(z, t)=C_{g, j}(0,0) e^{-\lambda_{j} t} \frac{\sinh \left|(x-z) \sqrt{\lambda_{j} / D_{e, j}}\right|}{\sinh \left(x \sqrt{\lambda_{j} / D_{e, j}}\right)}
$$

The cap is assumed to subside at closure, causing cracking of the cap. Cracks are assumed to create preferential pathways for gas release. The concentration profile in a crack is assumed to be given by Equation (A2.24) assuming the diffusion coefficient is equivalent to the free-air diffusion coefficient, or that the porosity is 1.0 and the saturated fraction is zero. The flux density from cracks is given by:

$$
j_{j}(z, t)=-D_{a, j} \frac{\partial C_{g_{j} j}(z, t)}{\partial z}
$$

where

$$
\mathrm{j}_{\mathrm{j}}(\mathrm{z}, \mathrm{t})=\text { the flux density of radionuclide } \mathrm{j} \text { per unit area of cracks, } \mathrm{Ci} /\left(\mathrm{m}^{2} \mathrm{yr}\right) \text {. }
$$

Assuming a percentage of the cap area is open cracks, $\mathrm{f}_{\mathrm{c}}$, the weighted mean flux density at the cap-air interface $(z=x)$ is given by:

$$
\begin{aligned}
J_{j}(x, t) & =C_{g_{j}}(0,0) e^{-\lambda_{j} t}\left[f_{c} \sqrt{\lambda_{j} D_{a, j}} \operatorname{csch}\left(x \sqrt{\frac{\lambda_{j}}{D_{a_{j}}}}\right)\right. \\
& \left.+\left(1-f_{c}\right) \varepsilon_{c} \sqrt{\lambda_{j} D_{e, j}} \operatorname{csch}\left(x \sqrt{\frac{\lambda_{j}}{D_{e, j}}}\right)\right]
\end{aligned}
$$


where

$$
\begin{aligned}
& \mathrm{J}_{\mathrm{j}}(\mathrm{x}, \mathrm{t})=\quad \begin{array}{l}
\text { the mean flux density at the cap-air interface of radionuclide } \mathrm{j} \text { per } \\
\mathrm{f}_{\mathrm{c}}
\end{array} \quad \begin{array}{l}
\text { unit area of the bulk medium, } \mathrm{Ci} /\left(\mathrm{m}^{2} \mathrm{yr}\right) ; \text { and } \\
\text { the fraction of the cap area as open cracks, dimensionless. }
\end{array}
\end{aligned}
$$

Tritium is assumed to be present predominantly as HTO. The plant transpiration loss of HTO is assumed to be equal to the flux density from the bare waste. The weighted mean flux density of ${ }^{3} \mathrm{H}$ is given by:

$$
\begin{gathered}
J_{H 3}(x, t)=C_{g, H 3}(0,0) e^{-\lambda_{H 3} t}\left[f_{c} \sqrt{\lambda_{H 3} D_{H 3}} \operatorname{csch}\left(x \sqrt{\frac{\lambda_{H 3}}{D_{H 3}}}\right)\right. \\
\left.+\left(1-f_{c}\right) \varepsilon_{c} \sqrt{\lambda_{H 3} D_{e, H 3}} \operatorname{csch}\left(x \sqrt{\frac{\lambda_{H 3}}{D_{e, H 3}}}\right)+\varepsilon_{w} \sqrt{\lambda_{H 3} D_{e, H 3}} \operatorname{coth}\left(x \sqrt{\frac{\lambda_{H 3}}{D_{e, H 3}}}\right)\right]
\end{gathered}
$$

where

$$
\varepsilon_{\mathrm{w}} \quad=\quad \text { air-filled waste porosity, dimensionless. }
$$

As a mass balance constraint, it is assumed that the flux density, integrated over one year and the disposal site area, cannot exceed the total waste inventory. Therefore, an upper limit on the steady-state flux density that can occur in any year is set as:

$$
J_{j, \max }(x, t)=\frac{C_{w j}(0) x_{w} e^{-\lambda_{j} t}}{\Delta t}
$$

where

$$
\begin{aligned}
& \mathrm{J}_{\mathrm{j}, \max }(\mathrm{x}, \mathrm{t})=\text { upper limit of gaseous flux density for radionuclide } \mathrm{j} \text { per unit area } \\
& \mathrm{C}_{\mathrm{w}, \mathrm{j}}(0)=\begin{array}{l}
\text { of the bulk medium, } \mathrm{Ci} /\left(\mathrm{m}^{2} \mathrm{yr}\right) ; \\
\text { waste concentration at closure for radionuclide } \mathrm{j}, \mathrm{Ci} / \mathrm{m}^{3} ;
\end{array} \\
& \mathrm{x}_{\mathrm{w}}=\text { unsubsided waste cell thickness, } \mathrm{m} \text {; } \\
& \mathrm{t}=\text { time elapsed since closure, yrs; and } \\
& \Delta \mathrm{t}=\text { regulatory interval, } 1 \mathrm{yr} \text {. }
\end{aligned}
$$


The initial concentration in the waste pore gas is calculated assuming the entire inventory is released to the gas-filled pore spaces. For all nuclides, excluding ${ }^{3} \mathrm{H}$, the pore gas concentration is given by:

$$
C_{g, j}(0,0)=\frac{C_{w_{2} j}(0)}{\varepsilon_{w}}
$$

The ${ }^{3} \mathrm{H}$ pore gas concentration is calculated assuming that the specific activity of ${ }^{3} \mathrm{H}$ in waste pore water is equal to the specific activity of vapor in the waste air-filled pore space. The ${ }^{3} \mathrm{H}$ concentration of the waste pore gas is given by:

$$
C_{g, H 3}(0,0)=10^{3} \frac{C_{w, j}(0) P_{v} M W}{\varepsilon_{T, w} S R T \rho_{H_{2} O}}
$$

where

$\begin{array}{lll}10^{3} & = & \text { unit conversion factor, } 1 \mathrm{e} 3 \mathrm{~L} / \mathrm{m}^{3} \\ \mathrm{P}_{\mathrm{v}} & = & \text { vapor pressure of water, } 1.2 \mathrm{e}-2 \text { atmospheres }(\mathrm{atm}) \\ \mathrm{MW} & = & \text { molecular weight of water, } 18 \mathrm{~g} / \mathrm{mole} ; \\ \varepsilon_{\mathrm{T}, \mathrm{w}} & = & \text { total waste porosity, } \mathrm{m}^{3} / \mathrm{m}^{3} \\ \mathrm{R} & = & \text { gas constant }(0.082 \mathrm{liter}-\text { atmospheres per mole-Kelvin }[\mathrm{L} \mathrm{atm} / \mathrm{mole} \\ \mathrm{T} & \mathrm{K}]) ; \\ \rho_{\mathrm{H} 2 \mathrm{O}} & =\text { temperature }(283 \mathrm{~K}) ; \text { and } \\ & & \text { density of water, } 1 \mathrm{e} 6 \mathrm{~g} / \mathrm{m}^{3}\end{array}$

The atmospheric concentration of volatile radionuclides directly over the disposal site was estimated assuming steady-state mixing of the flux into a compartment. The concentration of volatile gases direct above the disposal site was calculated as:

$$
C_{a v, j}(t)=\frac{J_{j}(x, t) \sqrt{A}}{H U}
$$

where

$$
\begin{array}{lll}
\mathrm{C}_{\mathrm{av}, \mathrm{j}}(\mathrm{t}) & =\text { atmospheric concentration of volatile radionuclide } \mathrm{j}, \mathrm{Ci} / \mathrm{m}^{3} ; \\
\mathrm{A} & = & \text { disposal unit area, } \mathrm{m}^{2} ; \\
\mathrm{U} & = & \text { annual mean wind speed, } \mathrm{m} / \mathrm{yr} ; \text { and } \\
\mathrm{H} & = & \text { height of the mixing zone, } \mathrm{m} .
\end{array}
$$


The off-site concentration of volatile radionuclides was estimated using the ISCLT model as described in Section A2.3 below.

Parameter Selection. All parameters are assumed to be variable except for the radiological decay constants, free-air diffusion coefficients, mixing zone height, and physical constants used to estimate water vapor pressure (Tables A2.9 and A2.10). The effective diffusion coefficient varies randomly with the relative moisture content and porosity.

The total cap porosity is based on measurements of fine-grained alluvium from Pit 6 (Reynolds Electrical \& Engineering Co., Inc. [REECo], 1993; Istok et al., 1994). Fine-grained alluvium is assumed to best represent the screened alluvium used to construct the closure cap. Porosity was assumed to be normally distributed, with a mean of 0.37 and standard deviation of 0.02 . Total waste porosity was assumed to be uniformly distributed between 0.3 and 0.7 . The lower limit represents a soil- like material and the upper limit is believed to be a physically reasonable value for waste. The air-filled porosity is estimated as the product of total porosity and the air-filled fraction or $(1-\mathrm{S})$. The relative moisture content is assumed to be triangularly distributed with a range between the lowest soil residual water content observed and saturated conditions. The mode is representative of the average Area 5 borehole volumetric water content, 0.09 .

A conservative conceptual model of crack formation was assumed to be that 2-cm (0.8-in) cracks formed every $30 \mathrm{~cm}$ (12 in) over the cap. This corresponds to a total area for open cracks equal to approximately 10 percent of the cap. Crack area was assumed to vary uniformly from 0 to 10 percent.

The height of the mixing zone directly over the site is assumed to be $2 \mathrm{~m}(6 \mathrm{ft})$. The annual mean wind speed is derived from data collected at the Area 5 RWMS meteorology station.

The estimated inventories of volatile radionuclides are described in Appendix 1 and listed in Table A2.3. The ${ }^{3} \mathrm{H}$ inventory is the sum of the shallow pits and trenches inventory and the GCD inventory. The randomly sampled radionuclide inventories are assumed to be correlated with a correlation coefficient of 1.0. The radionuclide concentrations are obtained by dividing by the waste volume. The waste volume is estimated as the product of waste disposal unit area and thickness. The radionuclide inventories are assumed to be correlated with disposal site area with a correlation coefficient of 0.5 .

Model Implementation. The gaseous release model was implemented with an Excel $^{\circ}$ spreadsheet. Monte Carlo calculations were implemented with the Crystal Ball (Ver. 4.0c) package (Decisioneering, 1996). The mean and 95th percentile volatile radionuclide fluxes were estimated from 10,000 Monte Carlo realizations. 


\begin{tabular}{|c|c|c|c|}
\hline Paramete & ues for Random & the Volatil & uclide Release Model \\
\hline Parameter & Parameter Value & Distribution & Source \\
\hline Cap Total Porosity, $\varepsilon_{\mathrm{T}, \mathrm{c}}$ & $\begin{array}{c}\text { Mean: } 0.37 \\
\text { Stand. Dev.: } 0.02\end{array}$ & Normal & $\begin{array}{l}\text { Total porosity is calculated from bulk densities and } \\
\text { particle densities measured in shallow alluvium taken } \\
\text { from the wall of Pit } 6 \text { (REECo, } 1993 \text {; Istok } \text { et al., } \\
\text { 1994). The distribution was assumed to be normal } \\
\text { (Kolmogorov-Smirnov D }=0.08, p=0.97, n=49 \text { ). } \\
\text { Porosity was assumed to range from } 0.25 \text { to } 0.45 \text {, based } \\
\text { on the observed range of the data set, } 0.27 \text { to } 0.41 \text {. }\end{array}$ \\
\hline Waste Total Porosity, $\varepsilon_{\mathrm{T}, \mathrm{w}}$ & 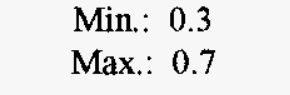 & Uniform & $\begin{array}{l}\text { Assumed to be physically reasonable range of } \\
\text { parameter. }\end{array}$ \\
\hline $\begin{array}{l}\text { Annual Mean Wind Speed, } \\
\mathrm{H}\end{array}$ & $\begin{array}{l}\text { Mean: } 2.6 \mathrm{~m} / \mathrm{s} \\
\text { Stand. Dev.: } 0.09\end{array}$ & Normal & Area 5 RWMS Meteorology Station \\
\hline $\begin{array}{l}\text { Relative Moisture Content, } \\
\text { S }\end{array}$ & $\begin{aligned} \text { Min.: } & 0.1 \\
\text { Mode: } & 0.25 \\
\text { Max.: } & 1.0\end{aligned}$ & Triangular & $\begin{array}{l}\text { The lower limit represents the residual water content of } \\
\text { alluvium. The mode assumes the mean volumetric } \\
\text { water content observed for Area } 5 \text { boreholes, } 0.09 \text {, and } \\
\text { the maximum represents saturated conditions. }\end{array}$ \\
\hline $\begin{array}{l}\text { Fraction of Cap Area as } \\
\text { Cracks, } f_{c}\end{array}$ & $\begin{array}{l}\text { Min: } 0 \\
\text { Max.: } 0.1\end{array}$ & Uniform & Assumed to be physically reasonable range of values. \\
\hline
\end{tabular}


Table A2.10 Fixed Parameter Values for the Volatile Radionuclide Release Model

\begin{tabular}{|c|c|c|c|c|c|}
\hline \multirow[b]{2}{*}{ Parameter } & \multicolumn{4}{|c|}{ Value } & \multirow[b]{2}{*}{ Source } \\
\hline & ${ }^{3} \mathbf{H}$ & ${ }^{14} \mathrm{C}$ & ${ }^{39} \mathrm{Ar}$ & ${ }^{85} \mathbf{K}$ & \\
\hline$\lambda_{\mathrm{j}, \mathrm{k}}\left(\mathrm{yr}^{-1}\right)$ & 0.0541 & $1.21 \mathrm{e}-4$ & $2.58 \mathrm{e}-3$ & 0.0646 & Kocher (1981) \\
\hline$D_{a, j, k}\left(m^{2} / y r\right)$ & 754 & 440 & 630 & 280 & CRC (1981); Am.. Inst. of Physics (1972) \\
\hline
\end{tabular}

\section{A2.3 Atmospheric Dispersion Model}

The ISCLT atmospheric dispersion model is used to estimate the airborne concentration and deposition rate of radionuclides beyond the boundaries of the Area 5 RWMS and contaminated soil sites.

\section{A2.3.1 Contaminated Soil Site Emissions}

The emission rates from contaminated soil sites was calculated using resuspension rates derived from NTS measurements. The calculation of the emission rates assumes:

- The resuspension rate is constant over time.

- The inventory of radioactive material changes over time by radioactive decay only.

- The inventory of short-lived fission and activation products decay to negligible levels during institutional control.

- The ingrowth of progeny over 1,000 years is negligible, except for production of ${ }^{241} \mathrm{Am}$ from ${ }^{241} \mathrm{Pu}$.

The emission rate of all radionuclides except ${ }^{241} \mathrm{Am}$ from surface soil contamination areas is estimated as:

$$
Q_{j}(t)=\frac{\operatorname{Ir} e^{-\lambda t}}{A}
$$

where

$\begin{array}{ll}\mathrm{Q}_{\mathrm{j}}(\mathrm{t}) & =\text { the flux density at time } \mathrm{t}, \mathrm{Ci} /\left(\mathrm{m}^{2} \mathrm{~s}\right) \\ \mathrm{I} & =\text { the inventory, } \mathrm{Ci} \\ \mathrm{r} & =\text { the resuspension rate, } \mathrm{s}^{-1} \\ \lambda & =\text { the radiological decay constant, } \mathrm{yr}^{-1} \\ \mathrm{t} & =\text { the elapsed time, yr; and } \\ \mathrm{A} & =\text { the area of the soil contamination area, } \mathrm{m}^{2} .\end{array}$


For ${ }^{241} \mathrm{Am}$, the emission rate was calculated as:

$$
Q_{A m 24 I}(t)=\frac{r}{A}\left[I_{2} e^{-\lambda_{2} t}+\frac{I_{1} \lambda_{2}}{\lambda_{2}-\lambda_{1}}\left(e^{-\lambda_{1} t}-e^{-\lambda_{2} t}\right)\right]
$$

where

$$
\begin{array}{lll}
\mathrm{I}_{1} & = & \text { the } \\
\mathrm{I}_{2} & = & \text { 241 } \mathrm{Pu} \text { inventory, } \mathrm{Ci} ; \\
\lambda_{1} & = & \text { the } \\
\lambda_{2} & = & \text { the }{ }^{241} \mathrm{Pu} \text { inventory }, \mathrm{Ci} ;
\end{array}
$$

The soil site inventories are based on the inventories reported by McArthur (1991) for Frenchman Flat playa; Gadgets, Mechanics, and Explosives (GMX); PIN STRIPE; and by Gilbert (1977) for Plutonium Valley (Table A2.11). Based on the subjective uncertainty in the inventory reported by McArthur (1991), the inventories are assumed to be normally distributed with 5th and 95th percentiles equal to one-half and two times the inventory values, respectively. The total ${ }^{239+240} \mathrm{Pu}$ activity reported by McArthur (1991) is partitioned assuming an isotopic composition characteristic of PU-52 weapons-grade plutonium after 36 years of radioactive decay (Shott et al., 1997a), as shown in Table A2.12. The inventory of ${ }^{241} \mathrm{Pu}$ is also estimated from the ${ }^{239+240} \mathrm{Pu}$ inventory based on the PU-52 composition. The soil site areas are taken from McArthur (1991) and Gilbert (1977) as those corresponding to the measured inventories.

The resuspension rate is the fraction of the inventory that is resuspended per unit time. Plutonium resuspension rates have been measured for some NTS contamination areas, including the GMX soil site and the Plutonium Valley soil site. The resuspension rates for the GMX soil site and the Plutonium Valley soil site are assumed to be loguniformly distributed about the values reported by Shinn et al. (1986), 2e-5 yr $\mathrm{yr}^{-1}$ and $1 \mathrm{e}-3 \mathrm{yr}^{-1}$, respectively. The resuspension rates at Frenchman Flat playa and PIN STRIPE were estimated from nuclear testing sites. Shinn et al. (1986) reported plutonium resuspension factors of $2 \mathrm{e}-5 \mathrm{yr}^{-1}$ for the LITTLE FELLER II site. This site has a low resuspension rate because the radioactive material is fused into large silicate glass particulates that are distributed throughout a crater ejecta blanket. The resuspension rates were assumed to be loguniformly distributed with limits an order of magnitude above and below the values reported by Shinn et al. (1986) (Table A2.13).

The contaminated soil site inventories will change as a function of time. The assumed institutional control period of 250 years allows the inventories of ${ }^{60} \mathrm{Co},{ }^{90} \mathrm{Sr},{ }^{137} \mathrm{Cs},{ }^{152} \mathrm{Eu}$, and ${ }^{154} \mathrm{Eu}$ to decay to negligible levels. Therefore, these nuclides were not included in the analysis. Because the PIN STRIPE soil site inventory contains only short-lived fission products, it will be an insignificant source after 250 years and can be eliminated. Screening of the radioactive decay chains included in the inventory indicates that the amount of ingrowth of progeny in 1,000 years 
Table A2.11 Soil Contamination Site Areas and Inventories as of 1990 Reported by McArthur (1991) and Gilbert (1977)

\begin{tabular}{ccccc}
\hline & $\begin{array}{c}\text { Frenchman Flat } \\
\text { Playa }\end{array}$ & GMX & PIN STRIPE & Pu Valley \\
\hline Area $\left(\mathrm{mi}^{2}\right)$ & 2.2 & 0.7 & 0.6 & 3.4 \\
\cline { 2 - 5 } & 1 & Inventory (Ci) & & \\
\hline${ }^{60} \mathrm{Co}$ & 1.1 & 0 & 0 & 0 \\
${ }^{90} \mathrm{Sr}$ & 0.4 & 0 & 0.2 & 0.2 \\
${ }^{137} \mathrm{Cs}$ & 12.1 & 0 & 0.2 & 0.4 \\
${ }^{152} \mathrm{Eu}$ & 0.8 & 0 & 0 & 0 \\
${ }^{154} \mathrm{Eu}$ & 0.1 & 0 & 0 & 0 \\
${ }^{238} \mathrm{Pu}$ & 3.4 & 0 & 0 & 0.5 \\
${ }^{239,240} \mathrm{Pu}$ & 0.4 & 1.4 & 0 & 29 \\
${ }^{241} \mathrm{Am}$ & 0.2 & 0 & 3.3 \\
\hline
\end{tabular}

Table A2.12 Assumed Radionuclide Composition of PU-52 Scrape Plutonium and Activity from $1 \mathrm{~g}$ After 36 Years of Decay (after Shott $e t$ al., 1997a)

\begin{tabular}{llc}
\hline Radionuclide & \multicolumn{1}{c}{ Mass Abundance at $\mathbf{t}=\mathbf{0}$} & Activity (Ci) at 36 Years from $\mathbf{1}$ g of PU-52 \\
\hline${ }^{238} \mathrm{Pu}$ & Fixed: $1 \mathrm{e}-4$ & $1.2 \mathrm{e}-3$ \\
${ }^{239} \mathrm{Pu}$ & Uniform: 1.0 - Mass Abundance of ${ }^{240} \mathrm{Pu}$ & $5.8 \mathrm{e}-2-5.9 \mathrm{e}-2$ \\
${ }^{240} \mathrm{Pu}$ & Uniform: $4 \mathrm{e}-2-7 \mathrm{e}-2$ & $9.0 \mathrm{e}-3-1.6 \mathrm{e}-2$ \\
${ }^{241} \mathrm{Pu}$ & Fixed: $3.6 \mathrm{e}-3$ & $4.9 \mathrm{e}-2$ \\
${ }^{242} \mathrm{Pu}$ & Fixed: $3 \mathrm{e}-4$ & $1.2 \mathrm{e}-6$ \\
${ }^{241} \mathrm{Am}$ & Fixed: 0 & $1.0 \mathrm{e}-2$ \\
\hline
\end{tabular}


Table A2.13 Assumed Resuspension Factors for Soil Sites (after Shinn et al., 1986)

\begin{tabular}{lc}
\hline \multicolumn{1}{c}{ Soil Site } & Resuspension Factor (yr) \\
\hline Frenchman Flat Playa & Loguniform: $2 \mathrm{e}-6-2 \mathrm{e}-4$ \\
GMX & Loguniform: $2 \mathrm{e}-6-2 \mathrm{e}-4$ \\
PIN STRIPE & Loguniform: $2 \mathrm{e}-6-2 \mathrm{e}-4$ \\
Plutonium Valley & Loguniform: $1 \mathrm{e}-4-1 \mathrm{e}-2$ \\
\hline
\end{tabular}

is negligible except for ${ }^{241} \mathrm{Am}$ produced by the decay of ${ }^{241} \mathrm{Pu}$. Therefore, ${ }^{241} \mathrm{Am}$ is the only radioactive progeny included in the estimate of the contaminated soil site emissions.

Other physical processes, such as erosion, weathering, and leaching of contamination into the soil column, might reduce resuspension over time. Resuspension of plutonium at the NTS has been observed to decrease over time (Anspaugh et al., 1975). Because these processes have not been quantified for 1,000 years in the future, they have conservatively been ignored.

Preliminary results obtained from the ISCLT model indicated that Plutonium Valley soil site was a major source of airborne plutonium at the Area $5 \mathrm{RWMS}$. The model estimated plutonium concentrations, however, were significantly higher than measured concentrations. The ISCLT model assumes a flat topography. There are several mountain ridges between Plutonium Valley and the Area 5 RWMS. These mountain ranges may reduce the atmospheric transport between the two sites. Model results excluding the Plutonium Valley soil site emissions yield results in better agreement with measured concentrations. Therefore, the Plutonium Valley soil site source term was not included in the final atmospheric dispersion modeling.

\section{A2.3.2 Atmospheric Dispersion Modeling}

The atmospheric dispersion modeling was performed with the U.S. Environmental Protection Agency's (EPA) ISCLT dispersion model (EPA, 1995a,b). The ISCLT model uses meteorological data and emission source data to simulate atmospheric dispersion and dry deposition at preassigned discrete receptor locations. The model description and the parameters selected for the analysis are presented below. The source documents should be consulted for further information on the model algorithms. (See the User's Guide for the Industrial Source Complex [ISC3] Dispersion Models, Volume I-User Instructions; and Volume II - Description of Model Algorithms.)

The ISCLT model uses the Gaussian plume equation to derive the air concentrations at receptor locations given the emission rates from multiple sources. The model accounts for:

- advection in the downwind direction;

- dispersion in crosswind (lateral) direction and vertical direction; 
- removal of contaminants from the plume by physical and chemical processes; and

- effects of source elevation, receptor elevation, plume rise, mixing in the vertical, and the gravitational and dry deposition of particulates with diameters greater than about 0.1 micrometers.

The model divides a given source area into sectors of equal angular width corresponding to the sectors of the annual frequency distributions of wind direction, wind speed, and stability. For the present application, there are 16 sectors for wind directions, 6 wind speed categories, and 6 stability classes. Annual emissions from the source are partitioned among the sectors according to the frequencies of wind blowing toward the sectors. The concentration fields calculated for each source (translated to a common coordinate system, polar or Cartesian) are summed to obtain the total due to all sources. ISCLT computes air concentrations at a receptor located downwind of all or a portion of the source area, by performing a double integration in the upwind and crosswind directions. Because the integration is performed over the area upwind of the receptor location, receptors may be located within the source area itself, downwind of the area, or adjacent to the area.

In addition to air concentrations of radionuclides at receptor locations, deposition rates are also calculated to estimate the accumulation of radionuclides in surface soil. The dry deposition model calculates the amount of material deposited (deposition flux) at the surface from a particle plume through dry deposition processes. The deposition flux is calculated as the product of the air concentration and a deposition velocity at a reference height. The effect of deposition on the depleted plume is also accounted for. For the current application, the plume was assumed not to deplete due to deposition. The deposition velocity is computed using a resistance method, which accounts for the effects of Brownian motion, inertial impact, and gravitational settling. The deposition rates were converted to surface soil concentrations as:

$$
C_{s, j}(t)=\frac{D_{j,} t}{x_{s} \rho_{s}}
$$

where

$\begin{array}{lll}\mathrm{C}_{\mathrm{s}, \mathrm{j}} & = & \text { surface soil concentration of radionuclide } \mathrm{j}, \mathrm{Ci} / \mathrm{g} ; \\ \mathrm{D}_{\mathrm{j}} & = & \text { deposition rate of radionuclide } \mathrm{j}, \mathrm{Ci} /\left(\mathrm{m}^{2} \mathrm{yr}\right) ; \\ \mathrm{t} & = & \text { time over which deposition occurs, } \mathrm{yr} ; \\ \mathrm{x}_{\mathrm{s}} & = & \text { depth of mixing of deposited radionuclide, } \mathrm{m} ; \text { and } \\ \rho_{\mathrm{s}} & = & \text { soil bulk density, } \mathrm{g} / \mathrm{m}^{3}\end{array}$


The mean and 95th percentile soil concentrations were estimated at 1,000 years using the 1,000-year deposition rate. Under the assumptions made to estimate the soil site emission rates, the emission rates and deposition rates vary little during the compliance period. Deposited contamination was assumed to be mixed to a depth of $0.15 \mathrm{~m}(0.5 \mathrm{ft})$.

\section{Model Setup and Parameter Selection}

The model was set up for three contaminated soil sites (the GMX soil site, the Frenchman Flat playa soil sites, and the Area 5 RWMS), and 204 receptor locations defined over a grid covering a portion of the Frenchman Flat where air concentrations and deposition rates were simulated. The locations of the sources are shown in Table A2.14. A source area in the model is a rectangular area defined by the coordinates of the lower left corner of the rectangular area, and its length and width. A mean and 95th percentile emission rate was assigned to each source for each radionuclide simulated using the method in the previous section. The surface soil concentrations for the GMX soil site and Frenchman Flat playa soil site were taken from site characterization data. The surface soil concentrations for the Area 5 RWMS were obtained from the nonvolatile radionuclide release models.

Table A2.14 Soil Source Emission Areas Used in the ISCLT Model

\begin{tabular}{lcccc}
\hline \multicolumn{1}{c}{ Soil Site } & Easting $(\mathbf{m})$ & Northing $(\mathbf{m})$ & Length $(\mathbf{m})$ & Area $\left(\mathbf{m}^{2}\right)$ \\
\hline Frenchman Flat playa soil site & 216,560 & 226,009 & 2,387 & $5.7 \mathrm{e} 6$ \\
GMX soil site & 217,383 & 232,197 & 1,346 & $1.8 \mathrm{e} 6$ \\
Area 5 RWMS & 215,581 & 233,477 & 344 & $1.2 \mathrm{e} 5$ \\
\hline
\end{tabular}

The ISCLT model uses joint frequency distributions of wind speed class, by wind direction sector, and by stability category, known as STAR (Stability Array) summaries. The average annual STAR summary data for the meteorological station Well 5B near the RWMS, obtained from the National Climatic Data Center in Asheville, North Carolina, was used in the air transport simulations.

The parameters for settling and deposition calculations included particle diameter and particle density. Particle diameter was taken conservatively (to increase deposition) as 20 microns for the dry deposition calculations. The particle density is assumed to be $2.43 \mathrm{~g} / \mathrm{cm}^{3}$. The surface roughness parameter for the dry deposition calculations was taken as $0.01 \mathrm{~m}(0.03 \mathrm{ft})$. Rural option default dispersion parameters were used in the model. Default values of wind-speed categories, wind profile exponents, and vertical temperature gradients were also used. The average annual ambient air temperature used in the model was $290 \mathrm{~K}$. The model assumed that the receptors were on a flat terrain, and the mixing height was taken as $1,000 \mathrm{~m}(3,300 \mathrm{ft})$. 


\section{A2.4 Screening Analysis of Upward Advection for Deep Waste Source Terms}

A screening analysis was performed to determine if upward advection is likely to transport radionuclides from the deep sources in P06U and GCD to the plant rooting zone in 1,000 years. The upward liquid flux rates, which drive the radionuclides, needed to be estimated because there were no direct measurements available. Chapman (1995) developed upward flux rates using deuterium and ${ }^{18} \mathrm{O}$ isotope data. An alternative estimate of upward flux was derived using soil physics data, presented below. Advective transport for radionuclides in P06U and GCD was then performed using the maximum upward flux rate derived from the isotope and soil physics data.

\section{A2.4.1 Method}

The upward water flux was calculated using Darcy's law:

$$
q=-k(\theta)\left(\frac{d \psi}{d z}-1\right)
$$

where

$$
\begin{array}{lll}
\mathrm{q} & = & \text { upward water flux, } \mathrm{m} / \mathrm{yr} ; \\
\theta & = & \text { volumetric water content, } \mathrm{m}^{3} / \mathrm{m}^{3} ; \\
\mathrm{k}(\theta) & = & \text { moisture-dependent (isotropic) hydraulic conductivity, } \mathrm{m} / \mathrm{yr} \text {; and } \\
\psi & = & \text { matric potential, } \mathrm{m} .
\end{array}
$$

In Equation A2.35, the vertical axis, $\mathrm{z}$, points downwäd. A negative flux indicates an upward flux.

In general, the flux is both nonuniform and non-steady-state. At the depths of the deep source terms at the Area $5 \mathrm{RWMS}, 10$ to $20 \mathrm{~m} \mathrm{(33}$ to $66 \mathrm{ft}$ ), the flux can be assumed to be constant. The flux was calculated assuming a matric potential gradient from a depth of about $21 \mathrm{~m}(69 \mathrm{ft})$ below the ground surface, which corresponds to the top of the waste in the GCD boreholes.

The van Genuchten-Mualem expressions were used to calculate the hydraulic conductivity:

$$
\theta=\theta_{r}+\left(\theta_{s}-\theta_{r}\right)\left[1+(-\alpha \psi)^{n}\right]^{-m}
$$


where

$\begin{array}{lll}\theta_{\mathrm{r}} & = & \text { residual water content, } \mathrm{m}^{3} / \mathrm{m}^{3} ; \\ \theta_{\mathrm{s}} & = & \text { saturated water content, } \mathrm{m}^{3} / \mathrm{m}^{3} ; \\ \alpha & = & \text { fitted parameter, } \mathrm{m}^{-1} ; \\ \mathrm{n} & = & \text { fitted parameter, dimensionless; and } \\ \mathrm{m} & = & \text { calculated parameter, dimensionless. }\end{array}$

The calculated parameter $m$ is related to $n$ by $m=1-1 / n$. The van Genuchten parameters were substituted into the Mualem expression to calculate the unsaturated hydraulic conductivity as:

$$
k(\theta)=k_{s} \sqrt{S}\left|1-\left(1-S^{1 / m}\right)^{m}\right|^{2}
$$

where

$$
\begin{gathered}
\mathrm{k}_{\mathrm{s}} \quad=\quad \begin{array}{l}
\text { saturated hydraulic conductivity, } \mathrm{m} / \mathrm{yr} ; \\
\mathrm{S}
\end{array} \quad \begin{array}{c}
\text { relative moisture content, dimensionless; and } \\
S=\frac{\theta-\theta_{r}}{\theta_{s}-\theta_{r}}
\end{array}
\end{gathered}
$$

The matric potential gradient with respect to depth, $\mathrm{d} \psi / \mathrm{dz}$, was calculated as follows. A curve was fit to the observed variation of matric potential with depth, and the slope of the curve d $\psi / d z$, at a depth of $21 \mathrm{~m}(61 \mathrm{ft})$, was calculated. The curve that best fit the data had the following form:

$$
z=\frac{a}{\psi}+b
$$

where ' $a$ ' and ' $b$ ' are the 'best-fit' parameters.

Once the advective flux is estimated, the distance a nonadsorbing radionuclide would travel in 1,000 years is estimated as:

$$
l=\frac{q t}{\theta}
$$


where

$$
\mathrm{t}=\quad \text { length of the compliance period, } 1,000 \text { years. }
$$

\section{A2.4.2 Model Implementation}

A Monte Carlo simulation approach was used in the analysis to account for uncertainty. Seventy retention curves (matric potential versus moisture content) and saturated hydraulic conductivities were generated for 70 core samples from six boreholes at the Area 5 RWMS (NN-1, AP-1, AP-2, RP-1, RP-2, and NW-1) (Blout et al., 1995). Each retention curve has an associated set of van Genuchten parameters that are required for the calculation of unsaturated hydraulic conductivity. Rather than prescribe distributions to the various van Genuchten parameters and sample them, the retention curve and saturated hydraulic conductivity were sampled randomly from the set of 70 samples. This has the advantage of preserving any correlations that might exist among the parameters.

Matric potential (as well as its gradient) were sampled from uniform distributions. The range of values for matric potential was chosen based on measurements at the depths of interest in the six boreholes. Likewise, the range of values for the gradient was based on values for the six boreholes.

In the Monte Carlo process, a retention curve was first randomly selected. This yielded the associated set of values for the van Genuchten parameters and the saturated hydraulic conductivity for that sample. Next, the matric potential was sampled from a uniform distribution ranging from -300 to $-200 \mathrm{~m}$. The distribution is biased toward lower suction pressures, yielding higher unsaturated hydraulic conductivities, and consequently conservatively higher upward advection. With the values of the van Genuchten parameters and matric potential in hand, the relative moisture content, $\mathrm{S}$, was calculated using Equations A2.36 and A2.38. The unsaturated hydraulic conductivity was calculated using Equation A2.37.

The gradient of matric potential with respect to depth was sampled from a uniform distribution ranging from -32 to -10 . The distribution is biased toward higher upward gradients, yielding conservatively higher upward advections. The advective flux was calculated using Equation A2.35. The distance a conservative radionuclide would travel in 1,000 years was then computed using Equation A2.40. This completes one realization. A total of 10,000 realizations were made, from which significant statistics for upward advective flux and travel distance were extracted.

\section{A2.4.3 Results}

Results of 10,000 Monte Carlo simulations exhibit a distribution of flux rates ranging from zero to a maximum of $4.3 \mathrm{e}-5 \mathrm{~m} / \mathrm{yr}(1.7 \mathrm{e}-3 \mathrm{in} / \mathrm{yr})$, with a mean of $1 \mathrm{e}-6 \mathrm{~m} / \mathrm{yr}(4 \mathrm{e}-5 \mathrm{in} / \mathrm{yr})$ and a standard deviation of $3 \mathrm{e}-6 \mathrm{~m} / \mathrm{yr}$ (1.2e-4 in/yr). Chapman's (1995) rates, based on stable isotope data, 
ranged from $1.1 \mathrm{e}-4$ to $5.5 \mathrm{e}-4 \mathrm{~m} / \mathrm{yr}(4 \mathrm{e}-3$ to $2 \mathrm{e}-2 \mathrm{in} / \mathrm{yr})$, with a mean of $2.7 \mathrm{e}-4$ (1e-2 in/yr) and a standard deviation of $1.4 \mathrm{e}-4 \mathrm{~mm} / \mathrm{yr}(5 \mathrm{e}-3 \mathrm{in} / \mathrm{yr})$.

Using the maximum flux rate from the stable isotope analysis, the distance that radionuclides would be transported upward in 1,000 years are computed and summarized in Table A2.15.

Table A2.15 Upward Advective Transport from Deep Waste Source Terms

\begin{tabular}{|c|c|c|c|c|}
\hline Element & $\begin{array}{c}K_{d} \\
\left(\mathbf{m}^{3} / \mathbf{k g}\right)\end{array}$ & Retardation Factor & $\begin{array}{l}\text { Mean Velocity } \\
\text { with Adsorption } \\
(\mathrm{m} / \mathrm{yr})\end{array}$ & $\begin{array}{c}\text { Mean 1,000-Year } \\
\text { Travel Length with } \\
\text { Adsorption (m) }\end{array}$ \\
\hline $\mathrm{Sr}$ & $1.5 \mathrm{e}-02$ & $1.3 \mathrm{e}+02$ & $2.3 \mathrm{e}-05$ & $2.3 \mathrm{e}-02$ \\
\hline $\mathrm{Tc}$ & $1.0 \mathrm{e}-04$ & $2.0 \mathrm{e}+00$ & $1.6 \mathrm{e}-03$ & $1.6 \mathrm{e}+00$ \\
\hline Cs & $2.8 \mathrm{e}-01$ & $2.4 \mathrm{e}+03$ & $1.3 \mathrm{e}-06$ & $1.3 \mathrm{e}-03$ \\
\hline $\mathrm{Ra}$ & $5.0 \mathrm{e}-01$ & $9.4 \mathrm{e}+03$ & $7.0 \mathrm{e}-07$ & $7.0 \mathrm{e}-04$ \\
\hline Ac & $4.5 \mathrm{e}-01$ & $3.9 \mathrm{e}+03$ & $7.8 \mathrm{e}-07$ & $7.8 \mathrm{e}-04$ \\
\hline Th & $3.2 \mathrm{e}+00$ & $2.8 \mathrm{e}+04$ & $1.1 \mathrm{e}-07$ & $1.1 \mathrm{e}-04$ \\
\hline $\mathrm{U}$ & $3.5 \mathrm{e}-02$ & $3.1 \mathrm{e}+02$ & $1.0 \mathrm{e}-05$ & $1.0 \mathrm{e}-02$ \\
\hline $\mathrm{Pu}$ & $5.5 \mathrm{e}-01$ & $4.8 \mathrm{e}+03$ & $6.4 \mathrm{e}-07$ & $6.4 \mathrm{e}-04$ \\
\hline
\end{tabular}

The advective velocity is computed by dividing the flux rate of water by the effective porosity and the retardation factor, which is computed as:

$$
R=1+\frac{\rho_{s} K_{d}}{\theta_{c}}
$$

where

$$
\begin{array}{ll}
\mathrm{R} & =\text { retardation factor, dimensionless, and; } \\
\theta_{\mathrm{c}} & =\text { effective moisture content, } \mathrm{m}^{3} / \mathrm{m}^{3} .
\end{array}
$$

The bulk density was $1,570 \mathrm{~kg} / \mathrm{m}^{3}$, and the effective porosity was 0.18 . The distribution coefficients $\left(\mathrm{K}_{\mathrm{d}}\right)$ are shown in the Table A2.15. The analysis indicates that upward advection is unlikely to transport radionuclides from P06U and GCD to the plant rooting zone in 1,000 years. 


\section{A2.5 Quality Assurance}

The Composite Analysis (CA) is prepared under the policies and procedures of the Bechtel Nevada Performance Assurance Management Plan (PAMP) (Bechtel Nevada [BN], 1996a). The PAMP implements the requirements of Title 10 Code of Federal Regulations (CFR) 830.120, "Quality Assurance Rule for Nuclear Facilities" (DOE, 1997); and DOE Order 5700.6C, "Quality Assurance Order" (DOE, 1991). The PAMP requirements are divided among 10 criteria: Program, Training and Qualification, Management Oversight and Quality Improvement, Management Assessment, Documents and Records, Work Processes, Design, Procurement, Inspection and Acceptance Testing, and Independent Assessment.

Many of the quality commitments above are implemented in BN Procedure L-F11.003, "Engineering Analysis/Calculations" (BN, 1996b), which describes the responsibilities and methods for review and approval of engineering calculations used in the $\mathrm{CA}$. The procedure includes requirements for:

- Defining a complete engineering calculation package.

- Verification of the computer software, input and output data, and calculation results.

- Procedures for approval, control, and retention of completed engineering calculations.

All CA calculation packages record the preparer, the computer software and hardware used, input data, and results, and are reviewed and approved by a qualified and independent reviewer. Calculation packages are numbered and retained for future review.

Computer software validation is interpreted to be the process of assuring that a computer model is a correct representation of the process or system being modeled. As the CA evaluates processes that can occur over a 1,000-year period, validation is considered a long-term goal. Computer software verification is defined as the process of assuring that computer software correctly performs a specified mathematical model. In some instances, software was found to have been adequately verified by the software developer. For these software packages, an installation verification was performed to determine that the installed software can reproduce results provided by the developer. All CA software has been verified.

\section{A2.5.1 Computer Code Implementation and Verification}

The verification status of computer codes is reviewed before use. Verification of computer codes used in the CA is described below.

\section{A2.5.1.1 Nonvolatile Radionuclide Release Model}

A FORTRAN computer code was written to solve the set of differential equations which describe the transfer of radionuclides from waste into the cap layers; and to perform the Monte Carlo simulations. A spreadsheet calculation using an analytical solution to the differential equations 
was performed to check the algorithms implemented in the code according to the "Engineering Analysis/Calculation procedure (BN, 1996b). Verification was performed for the fourth-order Runge-Kutta method used to solve the set of differential equations, and the random numbergenerating algorithms used to generate various probability distributions. It was assured that the random number generators preserved the parameters of the input distributions.

\section{A2.5.1.2 Volatile Radionuclide Release Model}

The volatile radionuclide release model consists of an analytical solution to a one-dimensional differential equation. The solution is implemented with an $\operatorname{Excel}^{\circ}$ spreadsheet. Monte Carlo uncertainty analyses are performed with the Crystal Ball package (Version 4.0c) (Decisioneering, 1996). The spreadsheet results are verified by hand calculation using the analytical solution.

\section{A2.5.1.3 Radiological Assessment Model}

The radiological assessment model follows the methods of Kennedy and Strenge (1992). The calculations are performed with an Excel $^{\circ}$ spreadsheet. Monte Carlo uncertainty analyses are performed with the Crystal Ball package (Version 4.0c) (Decisioneering, 1996). The spreadsheet calculations are verified by comparison with RESRAD (Version 5.61) (Yu et al., 1993) and by hand calculation. RESRAD is a DOE-developed and -supported code designed to develop guidelines for the cleanup of residual radioactive materials. The spreadsheet is also benchmarked against RESRAD for an intruder agriculture scenario. Results of the verification and benchmark are described in Shott et al. (1997b).

\section{A2.5.1.4 The ORIGEN2 Computer Code}

The ORIGEN2.1 computer code is used to calculate the radioactive ingrowth and decay of the disposal unit inventory. The ORIGEN2 code is a computer code developed by Oak Ridge National Laboratory for the calculation of the buildup, processing, and decay of radioactive materials (Croff, 1983). The ORIGEN2 code was verified by comparing its results to results obtained by hand calculation using well-known analytical solutions to the Bateman equations.

\section{A2.5.1.5 The ISCLT Computer Code}

The ISCLT computer code was used to model atmospheric dispersion from multiple sources within Frenchman Flat. The ISCLT code was developed and verified by the EPA (EPA, $1995 \mathrm{a}, \mathrm{b})$. The installation of the code was verified by comparing the results of sample problems with results reported by the developer.

\section{A2.6 References}

American Institute of Physics, 1972. American Institute of Physics Handbook. D. E. Gray (ed.). McGraw-Hill Book Co., New York, New York. 
Anderson, A. O., and D. M. Allred, 1964. "Kangaroo Rat Burrows at the Nevada Test Site." Great Basin Naturalist 24:93-101.

Anspaugh, L. R., J. H. Shinn, P. L. Phelps, and N. C. Kennedy, 1975. "Resuspension and Redistribution of Plutonium in Soils." Health Physics 29: 571-582.

Au, F. H. F, V. D. Leavitt, W. F. Beckert, and J. C. McFarlane, 1977. "Incorporation of Transuranics into Vegetation and Field Crops Grown at the Nevada Test Site." pp. 1-15. In: M. G White, P. B. Dunaway, and D. L. Wireman (eds.), Transuranics is Desert Ecosystems. NVO-181. U.S. Department of Energy/Nevada Operations Office, Las Vegas, Nevada.

Bamberg, S. A., A. T. Vollmer, G. E. Kleinkopf, and T. L. Ackerman, 1976. "A Comparison of Seasonal Primary Productivity of Mojave Desert Shrubs During Wet and Dry Years." The American Midland Naturalist 95(2): 398-405.

Barbour, M. G., 1973. "Desert Dogma Reexamined: Root/Shoot Productivity and Plant Spacing." Am. Mid. Nat. 89(1):41-57.

Bechtel Nevada, 1996a. Procedure B-A20/96.01, "Performance Assurance Management Plan." Bechtel Nevada, Las Vegas, Nevada.

_, 1996b. Procedure L-F11.003, "Engineering Analysis/Calculations." Bechtel Nevada, Las Vegas, Nevada.

Blom, P. E., W. H., Clark, and J. B. Johnson, 1991. "Colony Densities of the Seed- Harvesting Ant Pogonomyrmex salinus (Hymenoptera: Formicidae) in Seven Plant Communities on the Idaho National Engineering Laboratory." J. Idaho Acad. Science 27(1): 28-36.

Blout, D. O., W. S. Birchfield, D. P. Hammermeister, and K. A. Zukosky, 1995. Site Characterization Data From the Area 5 Science Boreholes, Nevada Test Site, Nye County, Nevada. DOE/NV/11432--170. U.S. Department of Energy/Nevada Operations Office, Las Vegas, Nevada.

Caldwell, M. M., R. S. White, R. T. Moore, and L. B. Camp, 1977. "Carbon Balance, Productivity, and Water Use of Cold-Winter Desert Shrub Communities Dominated by $\mathrm{C}_{3}$ and $\mathrm{C}_{4}$ Species." Oecologia 29: 275-300.

Chapman, J. B., 1995. "Evaporation Calculations at the Area 5 Radioactive Waste Management Site Based on Stable Isotope Data." Letter Report from Desert Research Institute to T. Brown, Sandia National Laboratories, November 14, 1995. 
— 1997. "Evaporation Calculations at the Area 3 Radioactive Waste Management Site Based on Stable Isotope Data." Letter Report from Desert Research Institute to B. Moore, Department of Energy, Nevada Operations Office, March 13, 1997.

— 1998. Personal Communication from J. B. Chapman to S. C. Mehrotra, April 16, 1998.

Chew, R. M., and A. E. Chew, 1965. "The Primary Productivity of a Desert-Shrub (Larrea Tridentata) Community." Ecological Monographs 35(4): 355-375.

Cline, J. F., K. A. Gano, and L. E. Rogers, 1980. "Loose Rock as Biobarriers in Shallow Land Burial." Health Physics 39: 497-504.

Croff, A. G., 1983. "ORIGEN2: A Versatile Computer Code for Calculating the Nuclide Compositions and Characteristics of Nuclear Materials." Nuclear Technology 62:335-352.

CRC Press, Inc., 1981. CRC Handbook of Chemistry and Physics. Robert C. Weast and Melvin J. Astle (eds.). Boca Raton, Florida.

Culot, M. J., H. G. Olson, and K. J. Shiager, 1976. "Effective Diffusion Coefficient of Radon in Concrete, Theory and Method for Field Measurements." Health Physics 30: 263-270.

Decisioneering, 1996. Crystal Ball (Version 4.0), User Manual. Decisioneering, Inc., Denver, Colorado.

DOE, 1998. Consequences of Subsidence for the Area 3 and Area 5 Radioactive Waste Management Sites, Nevada Test Site. DOE/NV--502, UC-600. U.S. Department of Energy/Nevada Operations Office, Las Vegas, Nevada.

_ 1997. "Quality Assurance Rule for Nuclear Facilities." Title 10 CFR 830. U.S. Government Printing Office, Washington, D.C.

— 1991. Order 5700.6C, "Quality Assurance Order." Washington, D.C., August 21.

EPA, 1995a. User's Guide for the Industrial Source Complex (ISC3) Dispersion Models Volume I - User Instructions. EPA-454/B-95-003a. U.S. Environmental Protection Agency, Research Triangle Park, North Carolina.

1995b. User's Guide for the Industrial Source Complex (ISC3) Dispersion Models Volume II-Description of Model Algorithms. EPA-454/B-95-003b, Research Triangle Park, North Carolina. 
Gilbert, R. O., 1977. "Revised Total Amounts of ${ }^{239,240} \mathrm{Pu}$ in Surface Soil at Safety-Shot Sites." pp. 423-430. In: M. G. White, P. B. Dunaway, and D. L. Wireman, (eds)., Transuranics in Desert Ecosystems. NVO-181. U.S. Department of Energy/Nevada Operations Office, Las Vegas, Nevada.

Fitzner, R. E., K. A. Gano, W. H. Rickard, and L. E. Rogers, 1979. Characterization of the Hanford 300 Area Burial Grounds: Task IV - Biological Transport. PNL-2774. Pacific Northwest Laboratory, Richland, Washington.

Foxx, T. S., G. D. Tierney, and J. M. Williams, 1984. Rooting Depths of Plants on Low-Level Waste Disposal Sites. LA-10253-MS. Los Alamos National Laboratory, Los Alamos, New Mexico.

Healy, J. W., 1980. "Review of Resuspension Models." pp. 209-235. In: W. C. Hanson (ed.), Transuranic Elements in the Environment. DOE/TIC-22800. U.S. Technical Information Service, Springfield, Virginia.

Istok, J. D., D. O. Blout, L. Barker, K. R. Johnejack, and D. P. Hammermeister, 1994. "Spatial Variability in Alluvium Properties at a Low-Level Nuclear Waste Site." Soil Science Society of Am. J. 58(4): 1040 - 1051.

Jury, W. A., W. R. Gardner, and W. H. Gardner, 1991. Soil Physics. John Wiley and Sons, New York, New York.

Kennedy, W. E., Jr., and D. L. Strenge, 1992. Residual Radioactive Contamination from Decommissioning, Vol. 1. NUREG/CR-5512. Pacific Northwest Laboratory, Richland Washington.

Kennedy, W. E., Jr., L. L. Cadwell, and D. H. McKenzie, 1985. "Biotic Transport of Radionuclides from Low-Level Radioactive Waste Site." Health Physics 49(1):11-24.

Klepper, E. L., K. A. Gano, and L. L. Cadwell, 1985. Rooting Depth and Distributions of DeepRooted Plants in the 200 Area Control Zone of the Hanford Site. PNL-5247. Pacific Northwest Laboratory, Richland, Washington.

Kocher, D. C., 1981. Radioactive Decay Data Tables: A Handbook of Decay Data for Application to Radiation Dosimetry and Radiological Assessments. DOE/TIC-11026. U.S. Department of Energy, Washington D.C.

Link, S. O., W. J. Waugh, J. L. Downs, M. E. Thiede, J. C. Chatters, and G. W. Gee, 1994. "Effects of Coppice Dune Topography and Vegetation on Soil Water Dynamics in a ColdDesert Ecosystem." J. of Arid Environments 27: 265-278. 
Manning, S. J., and D. P. Groeneveld, 1989. Shrub Rooting Characteristics and Water Acquisition on Xeric Sites in the Western Great Basin. Symposium on Cheatgrass Invasion, Shrub Die-Off, and Other Aspects of Shrub Biology and Management, Las Vegas, Nevada, April 5-7, 1989.

McArthur, R. D., 1991. Radionuclides in Surface Soil at the Nevada Test Site. DOE/NV/10845--02. Desert Research Institute, Water Resources Center, University of Nevada, Las Vegas, Nevada.

McGrew, J. C., 1979. "Vulpes macrotis." Mammalian Species 123: 1-6.

NCRP, 1984. Radiological Assessment: Predicting the Transport, Bioaccumulation, and Uptake by Man of Radionuclides Released to the Environmental. NCRP Report No. 76. National Council on Radiation Protection and Measurements, Bethesda, Maryland.

Ng, Y. C., C. S. Colsher, and S. E. Thompson, 1982. Soil-to-Plant Concentration Factors for Radiological Assessments. NUREG/CR-2975. Lawrence Livermore National Laboratory, Livermore, California.

Nutting, W. L., M. I. Haverty, and J. P. LaFage, 1985. "Physical and Chemical Alteration of Soil by Two Subterranean Termite Species in Sonoran Desert Grassland." J. of Arid Environ. 12:233-239.

Prudic, D. E., 1994. Estimates of Percolation Rates and Ages of Water in Unsaturated Sediments at Two Mojave. Desert Sites, California-Nevada. U.S. Geological Survey, Water-Resources Investigations Report 94-4160. U.S. Geological Survey, Denver, Colorado.

REECo, 1993. Hydrogeologic Data for Existing Excavations at the Area 5 Radioactive Waste Management Site, Nevada Test Site, Nye County, Nevada. DOE/NV/11432--40, UC 721. Reynolds Electrical \& Engineering Co., Inc., Las Vegas, Nevada.

Reynolds, T. D., and J. W. Laundre, 1988. "Vertical Distribution of Soil Removed by Four Species of Burrowing Rodents in Disturbed and Undisturbed Soils." Health Physics 54(4): 445-450.

Reynolds, T. D., and W. L. Wakkinen, 1987. "Characteristics of the Burrows of Four Species of Rodents in Undisturbed Soils in Southwestern Idaho." Am. Mid. Nat. 118(2): 245-250.

Romney, E. M., A. Wallace, J. E. Kinnear, and R. A. Wood, 1982. "Plant Root Uptake of Plutonium and Americium." pp. 185-199. In: W. A. Howard, P. B. Dunaway, and R. G. Fuller (eds.), The Radioecology of Transuranics and Other Radionuclides in Desert Ecosystems. NVO-224. U.S. Department of Energy/Nevada Operations Office, Las Vegas, Nevada. 
Sheppard, S. C., and W. G. Evenden, 1997. "Variation in Transfer Factors for Stochastic Models: Soil-to-Plant Transfer." Health Physics 72(5): 727-733.

Shinn, J. H., D. N. Homan, and C. B. Hoffman, 1986. A Summary of Plutonium Aerosol Studies: Resuspension at the Nevada Test Site. UCRL-90746. Lawrence Livermore National Laboratory, Livermore, California.

Shinn, J. H., and D. N. Homan, 1985. "Plutonium-Aerosol Emission Rates and Human Pulmonary Deposition Calculations for Nuclear Site 201, Nevada Test Site." pp. 261-278. In: W. A. Howard and R. G. Fuller (eds.), The Dynamic of Transuranics and Other Radionuclides in Natural Environments. NVO-272. U.S. Department of Energy/Nevada Operations Office, Las Vegas, Nevada.

Shott, G. J., L. E. Barker, S. E. Rawlinson, and M. J. Sully, 1997a. Performance Assessment for the Area 5 Radioactive Waste Management Site at the Nevada Test Site, Nye County, Nevada (Rev. 2.1). Bechtel Nevada, Las Vegas, Nevada.

Shott. G. J., V. Yucel, M. J. Sully, L. E. Barker, S. E. Rawlinson, and B. A. Moore, $1997 \mathrm{~b}$. Performance Assessment/Composite Analysis for the Area 3 Radioactive Waste Management Site at the Nevada Test Site, Nye County Nevada. DOE/NV--491. Bechtel Nevada, Las Vegas, Nevada.

Strojan, C. L., F. B. Turner, and R. Casetter, 1979. "Litter Fall from Shrubs in the Northern Mojave Desert." Ecology 60(5): 891-900.

Sturges, D. L., 1977. "Soil Water Withdrawal and Root Characteristics of Big Sagebrush." The American Midland Naturalist 98(20): 258-273.

Tabler, R. D., 1964. "The Root System of Artemisia Tridentata at 9,500 Feet in Wyoming." Ecology 45(3): 633-636.

Turner, F. B., and D. C. Randall, 1989. "Net Production by Shrubs and Winter Annuals in Southern Nevada." J. of Arid Environments 17: 23-36.

US Ecology, 1989. California Low-Level Radioactive Waste Disposal Facility License Application. US Ecology, Newport Beach, California.

Wallace, A., E. M. Romney, and J. W. Cha, 1980. "Depth Distribution of Roots of Some Perennial Plants in the Nevada Test Site Area of the Northern Mojave Desert." Great Basin Nat. Mem. 4:301-207.

Wallace, A., S. A. Bamberg, and J. W. Cha, 1974. "Quantitative Studies of Roots of Perennial Plants in the Mojave Desert." Ecology 55: 1160- 1162. 
Wallace, A., and E. M. Romney, 1972. Radioecology and Ecophysiology of Desert Plants at the Nevada Test Site. TID-25954. National Technical Information Center, U.S. Department of Commerce, Springfield, Virginia.

Whitford, W. G., Y. Steinberger, and G. Ettershank, 1982. Contributions of Subterranean Termites to the "Economy" of Chihuahuan Desert Ecosystems. Oecologia 55:298-302.

Winsor, T. F., and F. W. Whicker, 1980. "Pocket Gophers and Redistribution of Plutonium in Soil." Health Physics 39: 257-262.

Yu, C., C. Loureiro, J. J. Cheng, L. G. Jones, Y. Y. Wang, Y. P. Chia, and E. Faillace, 1993. Data Collection Handbook to Support Modeling the Impacts of Radioactive Material in Soil. ANL/EIAIS-8. Argonne National Laboratory, Argonne, Illinois. 


\section{APPENDIX 3}

\section{RADIOLOGICAL ASSESSMENT METHOD}




\section{CONTENTS}

A3.0 RADIOLOGICAL ASSESSMENT METHOD . . . . . . . . . . . . . A3-1

A3.1 Calculation of Pathway Dose Conversion Factors . . . . . . . . . . . A3-1

A3.1.1 Atmospheric Pathways $\ldots \ldots \ldots \ldots \ldots \ldots \ldots \ldots \ldots \ldots$ A3-1

A3.1.1.1 Soil Inhalation PDCF $\ldots \ldots \ldots \ldots \ldots \ldots \ldots \ldots \ldots$ A3-1

A3.1.1.2 Gas Inhalation PDCF $\ldots \ldots \ldots \ldots \ldots \ldots \ldots \ldots$ A3-3

A3.1.2 External Exposure Pathways $\ldots \ldots \ldots \ldots \ldots \ldots \ldots \ldots \ldots$ A3-3

A3.1.2.1 Gas Immersion PDCF . . . . . . . . . . . . A $3-3$

A3.1.2.2 External Irradiation PDCF $\ldots \ldots \ldots \ldots \ldots \ldots \ldots$ A3-4

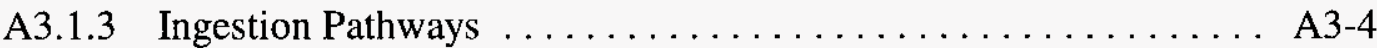

A3.1.3.1 Soil Ingestion PDCF $\ldots \ldots \ldots \ldots \ldots \ldots \ldots \ldots \ldots$ A3-5

A3.1.3.2 Plant Ingestion PDCF ................. A3-5

A3.1.3.3 Animal Product Ingestion PDCF . . . . . . . A3-6

A3.1.4 Converting Radionuclide Concentrations into Total Effective Dose Equivalent ....................... A3-10

A3.1.4.1 Calculation of the Scenario Dose Conversion Factors ...................... A3-10

A3.1.4.2 Calculation of the Total Effective Dose

Equivalent ..................... A3-11

A3.1.5 Selection of Parameter Values $\ldots \ldots \ldots \ldots \ldots \ldots \ldots \ldots$ A3-13

A3.1.5.1 Soil Inhalation Pathway $\ldots \ldots \ldots \ldots \ldots \ldots \ldots$ A3-13

A3.1.5.2 Gas Inhalation Pathway . . . . . . . . . . . A3-23

A3.1.5.3 Air Immersion Pathway .............. A3-23

A3.1.5.4 External Irradiation Pathway .............. A3-23

A3.1.5.5 Inadvertent Soil Ingestion Pathway . . . . . . . . A3-23

A3.1.5.6 Agricultural Pathways . . . . . . . . . . . . A3-24

A3.1.6. Model Implementation $\ldots \ldots \ldots \ldots \ldots \ldots \ldots \ldots \ldots$ A3-25

A3.1.6.1 Uncertainty and Sensitivity of Pathway Dose

Factors .................... A3-25

A3.1.6.2 Verification and Benchmarking $\ldots \ldots \ldots \ldots \ldots$ A3-25

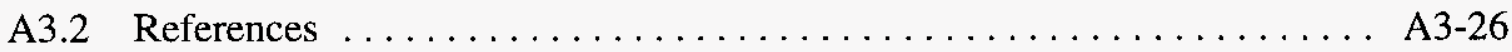




\section{List of Tables}

A3.1 Parameter Values for Nonagricultural Pathways . . . . . . . . . . . . . . A3-14

A3.2 Agricultural Pathway Parameters for Water-Independent Pathways . . . . . . . . A3-15

A3.3 Dry Plant-Soil Concentration Ratios and Animal Product Transfer Factors . . . . . A3-17

A3.4 Dose Conversion Factors . . . . . . . . . . . . . . . . . . . . . . A3-19

A3.5 Mean and Standard Deviation of the SDCFs for Soil $\ldots \ldots \ldots \ldots \ldots \ldots \ldots \ldots$ A3-21

A3.6 Mean and Standard Deviation of the SDCFs for Nonvolatile and Volatile

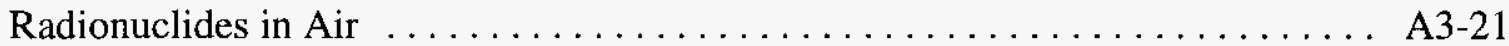




\section{ACRONYMS}

$\begin{array}{ll}\text { GMX } & \text { Gadgets, Mechanics, and Explosives } \\ \text { ISCLT } & \text { Industrial Source Code Long-Term } \\ \text { PDCF } & \text { Pathway Dose Conversions Factors } \\ \text { RIDP } & \text { Radionuclide Inventory and Distribution Program } \\ \text { RWMS } & \text { Radioactive Waste Management Site } \\ \text { SDCF } & \text { Scenario Dose Conversion Factor } \\ \text { TEDE } & \text { Total Effective Dose Equivalent }\end{array}$




\section{This Page Intentionally Left Blank}




\section{A3.0 RADIOLOGICAL ASSESSMENT METHOD}

The radiological assessment method calculates total effective dose equivalent (TEDE) as the product of a scenario dose conversion factor (SDCF) and the concentration of the radionuclide in soil and air obtained from external transport models. The SDCFs are calculated as the sum of individual pathway dose conversions factors (PDCFs). The PDCFs are derived from the method of Kennedy and Strenge (1992) for converting residual contamination into TEDE. They estimate the TEDE expected per unit concentration of a radionuclide through a single pathway such as inhalation of resuspended soil. The objective of the calculation is to derive a best estimate of the SDCF rather than a worst-case value, and is based on U.S. Department of Energy (DOE) guidance (Wood et al., 1994). This Appendix describes the derivation of the SCDFs, PDCFs, and the calculation of the TEDEs.

\section{A3.1 Calculation of Pathway Dose Conversion Factors}

The PDCF is the radionuclide- and pathway-specific ratio of TEDE to unit concentration in soil or air. The calculation of the PDCF has been derived algebraically from the radiological assessment methods of Kennedy and Strenge (1992) for a residential scenario, with exceptions and modifications as noted. The only consistent change is that radioactive decay during the period of assessment is ignored. Radioactive decay during the one-year exposure period or between harvest and intake will be minor for the long-lived radionuclides considered in a waste inventory and can be neglected (Wood et al., 1994).

\section{A3.1.1 Atmospheric Pathways}

Residents may be exposed to radionuclides in air as gases or attached to suspended soil particulates. Exposure to atmospheric radioactivity may occur through inhalation, dermal absorption, and external irradiation.

\section{A3.1.1.1 Soil Inhalation PDCF}

The PDCF for inhalation of suspended soil particulates is calculated as:

$$
P D C F_{H, j}=D F H_{j} \sum_{m=1}^{P}\left[\left(C D_{i, m}+C D_{o, m}\right) E F V_{m} t_{m}\right]
$$

where

$$
\begin{array}{lll}
\mathrm{PDCF}_{\mathrm{H}, \mathrm{j}} & = & \text { soil inhalation PDCF for radionuclide } \mathrm{j} \text { in soil, }(\mathrm{mrem} \mathrm{g}) /(\mathrm{Ci} \mathrm{yr}) \\
\mathrm{DFH}_{\mathrm{j}} & = & \text { inhalation dose factor }(\mathrm{DF}) \text { for radionuclide } \mathrm{j}, \mathrm{mrem} / \mathrm{Ci} ; \\
\mathrm{P} & = & \text { number of time intervals with different ventilation rates and mass } \\
& & \text { loading levels, dimensionless; }
\end{array}
$$




$\begin{array}{lll}\mathrm{CD}_{\mathrm{o}, \mathrm{m}} & = & \text { outdoor mass loading during time interval } \mathrm{m}, \mathrm{g} / \mathrm{m}^{3} ; \\ \mathrm{EF} & = & \text { enrichment factor, dimensionless; } \\ \mathrm{V}_{\mathrm{m}} & = & \text { ventilation rate during interval } \mathrm{m}, \mathrm{m}^{3} / \mathrm{hr} ; \text { and } \\ \mathrm{t}_{\mathrm{m}} & = & \text { hours of exposure per year for interval } \mathrm{m}, \mathrm{hr} / \mathrm{yr}\end{array}$

The PDCF is calculated as the product of the inhalation DF and the annual intake of soil particulates by inhalation. The summation in Equation A3.1 gives the annual intake of soil particulates. The day is assumed to be divided into several intervals with different ventilation rates and mass loading values. Kennedy and Strenge (1992) assumed an indoor interval, an outdoor interval, and a gardening interval. The model allows for an indoor resting interval, an indoor active interval, an outdoor interval, and a gardening interval. Ventilation rates are assumed to vary in each interval with activity level. Also different from the model of Kennedy and Strenge (1992) is the use of an enrichment factor. The enrichment factor is the ratio of the activity concentration of airborne soil particulates to the activity concentration of soil in the contamination area. Enrichment factors have been used to assess inhalation doses at sites on the Nevada Test Site (NTS) contaminated by atmospheric weapon testing (Layton et al., 1993; and Shinn and Homan, 1985). Intense heat from the nuclear explosion has fused soil contamination at these sites into large soil particulates that are not readily resuspended (Shinn et al., 1986; and Shinn and Homan, 1985). The enrichment factor is assumed to be 1.0 for all analyses in the Composite Analysis (CA).

Mass loading is assumed to vary with location and the activity being performed. Outdoor mass loading describes the concentration of particulates in air from wind resuspension and mechanical resuspension. Indoor mass loading describes resuspension of soil in the residence. While indoors, mass loading is calculated as the sum of indoor and outdoor mass loading. This is a conservative assumption that reflects the uncertainty of indoor mass loading. The soil inhalation PDCF is calculated for all radionuclides except the noble gases, which are always present in a gaseous form.

An additional soil particulate inhalation PDCF in units of mrem $/ \mathrm{yr}$ per $\mathrm{Ci} / \mathrm{m}^{3}$ of air is calculated for use with the atmospheric dispersion model (Industrial Source Code Long-Term [ISCLT]) that estimate atmospheric concentrations. The PDCF for inhalation of airborne soil particulates is calculated as:

$$
P D C F_{A, j}=D F H_{j} \sum_{m=1}^{P}\left[E F V_{m} t_{m}\right]
$$

where

$$
\begin{aligned}
\mathrm{PDCF}_{\mathrm{A}, \mathrm{j}}=\quad \begin{array}{l}
\text { airborne soil inhalation PDCF for radionuclide } \mathrm{j} \text { in air, (mrem } \\
\left.\mathrm{m}^{3}\right) /(\mathrm{Ci} \text { yr). }
\end{array} &
\end{aligned}
$$


The PDCF is calculated as the product of the inhalation DF and the annual volume of contaminated air inhaled.

\section{A3.1.1.2 Gas Inhalation PDCF}

The PDCF for inhalation of gases is calculated as:

$$
P D C F_{G H_{j}}=D F G_{j} \sum_{m=1}^{P}\left(V_{m} t_{m}\right)
$$

where

$$
\begin{array}{lll}
\mathrm{PDCF}_{\mathrm{GH}, \mathrm{j}} & =\text { gas inhalation PDCF for radionuclide } \mathrm{j} \text { in air, }\left(\mathrm{mrem} \mathrm{m} \mathrm{m}^{3}\right) /(\mathrm{Ci} \mathrm{yr}) \\
\mathrm{DFG}_{\mathrm{j}} & =\text { inhalation DF for radionuclide } \mathrm{j}, \mathrm{mrem} / \mathrm{Ci} ; \\
\mathrm{V}_{\mathrm{m}} & =\text { ventilation rate during interval } \mathrm{m}, \mathrm{m}^{3} / \mathrm{hr} ; \text { and } \\
\mathrm{t}_{\mathrm{m}} & =\text { hours of exposure per year for interval } \mathrm{m}, \mathrm{hr} / \mathrm{yr} .
\end{array}
$$

The PDCF is calculated as the product of the inhalation DF and the total volume of contaminated air inhaled annually. The summation gives the annual intake of the gas. The exposure period is assumed to be divided into several intervals with varying ventilation rates. The gas inhalation PDCF was calculated for ${ }^{3} \mathrm{H}$ and ${ }^{14} \mathrm{C}$ only. The ${ }^{3} \mathrm{H}$ DF has been multiplied by a factor of 1.5 to account for dermal absorption of tritiated water vapor (HTO) (International Commission on Radiation Protection [ICRP], 1979). Tritium, ${ }^{14} \mathrm{C}$, and noble gases are the only gases in the inventory. The immersion dose from noble gases, excluding radon and thoron, exceeds the inhalation dose (ICRP, 1979). Therefore, inhalation DFs for noble gases are not commonly available.

\section{A3.1.2 External Exposure Pathways}

External exposure is considered from sources in the ground, gases in the atmosphere, and suspended particulates. External irradiation from suspended particulates was found to be insignificant and was ignored.

\section{A3.1.2.1 Gas Immersion PDCF}

The PDCF for immersion in gases is calculated as:

$$
P D C F_{I M, j}=D F I_{j} \sum_{m=1}^{P} t_{m}
$$


where

$$
\begin{array}{ll}
\mathrm{PDCF}_{\mathrm{IM}, \mathrm{j}} & =\text { gas immersion PDCF for radionuclide } \mathrm{j} \text { in soil, }\left(\mathrm{mrem} \mathrm{m} \mathrm{m}^{3}\right) /(\mathrm{Ci} \mathrm{yr}) \\
\mathrm{DFI}_{\mathrm{j}} & =\text { air immersion DF for radionuclide } \mathrm{j},\left(\mathrm{mrem} \mathrm{m} \mathrm{m}^{3}\right) /(\mathrm{Ci} \mathrm{hr}) ; \text { and } \\
t_{\mathrm{m}} & =\text { hours of exposure per year for interval } \mathrm{m}, \mathrm{hr} / \mathrm{yr} .
\end{array}
$$

The gas immersion PDCF is calculated as the product of the immersion DF and the time of exposure. Indoor and outdoor exposure are assumed to be equivalent.

The immersion dose can also be calculated for suspended soil particulates. Screening of this pathway indicates that the dose from inhalation or external exposure from the ground surface is much greater. For all radionuclides, the dose from immersion was less than 0.1 percent of the dose from inhalation and external exposure. Therefore, this pathway can be ignored for nonvolatile radionuclides. The PDCFs are calculated for gaseous radionuclides only.

\section{A3.1.2.2 External Irradiation PDCF}

The PDCF for external irradiation is calculated as:

$$
P D C F_{E X_{j}}=D F E_{j} \rho_{s} \sum_{m=1}^{P}\left(S F_{m} t_{m}\right)
$$

where

$$
\begin{array}{lll}
\mathrm{PDCF}_{\mathrm{EX}, \mathrm{j}} & =\text { external PDCF for radionuclide } \mathrm{j} \text { in soil, }(\mathrm{mrem} \mathrm{g}) /(\mathrm{Ci} \mathrm{yr}) \\
\mathrm{DFE}_{\mathrm{j}} & =\text { external DF for radionuclide } \mathrm{j},\left(\mathrm{mrem} \mathrm{m} \mathrm{m}^{3}\right) /(\mathrm{Ci} \mathrm{hr}) \\
\rho_{\mathrm{s}} & =\text { soil bulk density, } \mathrm{g} / \mathrm{m}^{3} ; \\
\mathrm{SF}_{\mathrm{m}} & =\text { transmission factor during interval m, dimensionless; and } \\
\mathrm{t}_{\mathrm{m}} & =\text { hours of exposure per year for interval } \mathrm{m}, \mathrm{hr} / \mathrm{yr}
\end{array}
$$

The external irradiation PDCF is the product of the geometry-specific DF and the weighted time of exposure. The external DFs are for soil contaminated to a depth of $0.15 \mathrm{~m}(0.5 \mathrm{ft})$. The time of exposure is weighted by a transmission factor accounting for attenuation provided by the residence.

\section{A3.1.3 Ingestion Pathways}

Ingestion is assumed to occur through inadvertent ingestion of soil and through ingestion of vegetables, beef, poultry, milk, and eggs. 


\section{A3.1.3.1 Soil Ingestion PDCF}

The soil ingestion PDCF is calculated as:

$$
P D C F_{G S, j}=D F G_{j} G R \frac{1}{8766} \sum_{m=1}^{P} t_{m}
$$

where

$\begin{array}{lll}\mathrm{PDCF}_{\mathrm{GS}, \mathrm{j}} & = & \text { soil ingestion PDCF for radionuclide } \mathrm{j} \text { in soil, (mrem g)/(Ci yr); } \\ \mathrm{DFG}_{\mathrm{j}} & = & \text { ingestion DF for radionuclide } \mathrm{j}, \mathrm{mrem} / \mathrm{Ci} ; \\ \mathrm{GR} & = & \text { annual soil intake, } \mathrm{g} / \mathrm{yr} ; \\ 8766 & = & \text { total hours per year; and } \\ \mathrm{t}_{\mathrm{m}} & = & \text { hours of exposure per year for interval } \mathrm{m}, \mathrm{hr} / \mathrm{yr} .\end{array}$

The soil ingestion PDCF is the product of the ingestion DF and the annual intake of soil. The soil intake accounts for incidental intake of soil from hand-to-mouth contact and contamination of food and drink. Intake is weighted with the fractional time of exposure in the contaminated area. Intake of soil from ingestion of plants grown in contaminated soil is modeled with the plant ingestion PDCF.

\section{A3.1.3.2 Plant Ingestion PDCF}

The plant ingestion PDCF is calculated as:

$$
P D C F_{V G, j}=1000 D I E T_{p} D F G_{j} \sum_{p=1}^{Q}\left[U_{v, p}\left(M L_{v, p}+B_{j, v, p}\right) W_{v, p}\right]
$$

where

$$
\begin{array}{lll}
\mathrm{PDCF}_{\mathrm{VG}, \mathrm{j}} & =\text { plant ingestion PDCF for radionuclide } \mathrm{j} \text { in soil, (mrem } \mathrm{g}) /(\mathrm{Ci} \mathrm{yr}) \\
1000 & \mathrm{~g} / \mathrm{kg} ; \\
\mathrm{DIET}_{\mathrm{p}} & =\text { fraction of annual plant diet produced at home, dimensionless; } \\
\mathrm{DFG}_{\mathrm{j}} & =\text { ingestion DF for radionuclide } \mathrm{j}, \text { mrem } / \mathrm{Ci} ; \\
\mathrm{Q} & =\text { number of plant varieties in model (leafy vegetables, root } \\
& & \text { vegetables, fruit, and grain), dimensionless; } \\
\mathrm{U}_{\mathrm{v}, \mathrm{p}} & = & \text { annual consumption rate of plant type } \mathrm{p}, \mathrm{kg}(\mathrm{wet}) / \mathrm{yr} ; \\
\mathrm{ML}_{\mathrm{v}, \mathrm{p}} & = & \text { soil mass loading on plant } \mathrm{p} \text { surfaces, } \mathrm{Ci} / \mathrm{kg} \text { plant }(\mathrm{dry}) \text { per } \mathrm{Ci} / \mathrm{kg} \\
& & \text { soil (dry); }
\end{array}
$$




$$
\begin{aligned}
& \mathrm{B}_{\mathrm{j}, \mathrm{v}, \mathrm{p}}=\text { plant-to-soil concentration ratios for radionuclide } \mathrm{j} \text { and plant } \mathrm{p} \text {, } \\
& \mathrm{Ci} / \mathrm{kg} \text { plant (dry) per } \mathrm{Ci} / \mathrm{kg} \text { soil (dry); and } \\
& \mathrm{W}_{\mathrm{v}, \mathrm{p}}=\text { dry-to-wet mass ratio for plant type } \mathrm{p} \text {, dimensionless; }
\end{aligned}
$$

The PDCF is the product of the ingestion DF, the fraction of ingested plants grown in the contaminated area, the total plant ingestion rate, and the concentration ratio of the radionuclide in the plant to the soil. The plant-to-soil concentration ratio is calculated as the sum of the dry soil mass loading and a root uptake-derived dry weight concentration ratio.

The plant-to-soil concentration ratio for ${ }^{3} \mathrm{H}$ is calculated using a specific activity model as:

$$
B_{H 3, v, p}=\frac{9 f_{H v, p} S A_{s v H}}{S_{H}}
$$

where

$\begin{array}{lll}9 & = & \mathrm{kg} \mathrm{H} \\ 2 & \mathrm{O} / \mathrm{kg} \mathrm{H} ; \\ \mathrm{f}_{\mathrm{Hv}, \mathrm{p}} & = & \mathrm{H} \text { mass fraction of plant } \mathrm{p}, \mathrm{kg} \mathrm{H} \text { in plant } / \mathrm{kg} \text { plant (wet); } \\ \mathrm{SA}_{\mathrm{svH}} & = & \begin{array}{l}\text { specific activity ratio, } \mathrm{Ci} / \mathrm{kg} \mathrm{H} \text { in plant per Ci/kg H in soil } \\ \text { (assumed to be unity); and }\end{array} \\ \mathrm{S}_{\mathrm{H}} & = & \text { gravimetric water content of soil, } \mathrm{kg} \mathrm{H}_{2} \mathrm{O} / \mathrm{kg} \text { soil. }\end{array}$

The model assumes that the specific activity of plant material is equivalent to the specific activity of $\mathrm{H}$ in soil water.

Uptake of ${ }^{14} \mathrm{C}$ from soil by plants has been shown to include a gaseous pathway, which may be the predominant pathway under certain circumstances (Amiro et al., 1991). However, modeling the uptake of gaseous ${ }^{14} \mathrm{C}$ requires estimating the concentration in air. Rather than attempt to model gaseous uptake, concentration ratios based on lysimeter experiments which include both root and $\mathrm{CO}_{2}$ uptake have been chosen (Sheppard et al., 1991).

\section{A3.1.3.3 Animal Product Ingestion PDCF}

The animal product ingestion PDCF is calculated as:

$$
\begin{aligned}
P D C F_{A G, j}=1000 D I E T_{a} D F G_{j} \sum_{q=1}^{R} & {\left[U _ { a , q } F _ { a , j , q } \left\{\sum_{p=1}^{S}\left[Q_{p} x_{p}\left(M L_{v, p}+B_{j, v, p}\right) W_{v, p}\right]\right.\right.} \\
& \left.\left.+Q_{d} W_{f} Q_{f} x_{f}\right\}\right]
\end{aligned}
$$


where

\begin{tabular}{|c|c|c|}
\hline $\mathrm{PDCF}_{\mathrm{AG}, \mathrm{j}}$ & $=$ & animal ingestion PDCF for radionuclide $\mathrm{j}$ in soil, $(\mathrm{mrem} \mathrm{g}) /(\mathrm{Ci} \mathrm{yr})$ \\
\hline 1000 & $=$ & $\mathrm{g} / \mathrm{kg}$ \\
\hline DIET $_{a}$ & $=$ & fraction of annual animal diet produced at home, dimensionless; \\
\hline $\mathrm{DFG}_{\mathrm{j}}$ & $=$ & ingestion $\mathrm{DF}$ for radionuclide $\mathrm{j}, \mathrm{mrem} / \mathrm{Ci}$; \\
\hline $\mathrm{R}$ & $=$ & $\begin{array}{l}\text { number of animal products in model (beef, milk, poultry, and } \\
\text { eggs), dimensionless; }\end{array}$ \\
\hline $\mathrm{U}_{\mathrm{a}, \mathrm{q}}$ & $=$ & $\begin{array}{l}\text { annual consumption rate of animal product } \mathrm{q}, 1 / \mathrm{yr} \text { for milk and } \mathrm{kg} \\
\text { (wet)/yr for all other animal products; }\end{array}$ \\
\hline $\mathrm{F}_{\mathrm{a}, \mathrm{j}, \mathrm{q}}$ & $=$ & $\begin{array}{l}\text { food-to-animal transfer factor for radionuclide } \mathrm{j} \text { and animal } \mathrm{q}, \mathrm{d} / \mathrm{l} \\
\text { (wet) for milk and } \mathrm{d} / \mathrm{kg} \text { (wet) for all other animal products; }\end{array}$ \\
\hline $\mathrm{S}$ & $=$ & $\begin{array}{l}\text { number of animal feeds in model (forage, hay, and grain), } \\
\text { dimensionless; }\end{array}$ \\
\hline$Q_{p}$ & $=$ & animal consumption rate of plant $\mathrm{p}, \mathrm{kg}$ (wet)/d; \\
\hline $\mathrm{x}_{\mathrm{p}}$ & $=$ & $\begin{array}{l}\text { fraction of animal intake of plant } \mathrm{p} \text { that is contaminated, } \\
\text { dimensionless; }\end{array}$ \\
\hline $\mathrm{ML}_{\mathrm{v}, \mathrm{p}}$ & $=$ & $\begin{array}{l}\text { soil mass loading on plant p surfaces, } \mathrm{Ci} / \mathrm{kg} \text { plant (dry) per } \mathrm{Ci} / \mathrm{kg} \\
\text { soil (dry); }\end{array}$ \\
\hline$B_{j, v, p}$ & $=$ & $\begin{array}{l}\text { plant-to-soil concentration ratios for radionuclide } \mathrm{j} \text { and plant } \mathrm{p} \text {, } \\
\mathrm{Ci} / \mathrm{kg} \text { plant (dry) per } \mathrm{Ci} / \mathrm{kg} \text { soil (dry); }\end{array}$ \\
\hline$W_{v, p}$ & $=$ & dry-to-wet mass ratio for plant type $\mathrm{p}$, dimensionless; \\
\hline$Q_{d}$ & $=$ & $\begin{array}{l}\text { fraction of animal forage intake that is soil, } \mathrm{kg} \text { (dry) soil/kg (dry) } \\
\text { forage; }\end{array}$ \\
\hline $\mathrm{W}_{\mathrm{f}}$ & $=$ & dry-to-wet mass ratio for forage, dimensionless; \\
\hline $\mathrm{Q}_{\mathrm{f}}$ & $=$ & animal consumption rate of forage, $\mathrm{kg}$ (wet)/d; and \\
\hline$x_{f}$ & $=$ & $\begin{array}{l}\text { fraction of animal intake of forage that is contaminated, } \\
\text { dimensionless. }\end{array}$ \\
\hline
\end{tabular}

The animal product ingestion pathway DF is calculated as the product of the fraction of the diet that is home produced, the ingestion DF, the annual consumption rate, and the fractional transfer of soil contamination to the animal product. Soil contamination is transferred to the animal product through the ingestion of forage, hay, grain, and soil. Forage, hay, and grain accumulate contamination from root uptake and soil deposition.

The animal product ingestion pathway DF for ${ }^{3} \mathrm{H}$ is calculated using a specific activity model as:

$$
\begin{gathered}
P D C F_{A G, H 3}=1000 D I E T_{a} D F G_{H 3} \sum_{q=1}^{R}\left[U_{a, q} f_{H, q} S A_{T a \ddot{H}}\right. \\
\left.\times\left\{\frac{\sum_{p=1}^{S}\left[Q_{p} x_{p}\left(B_{H 3, v, p}+M L_{v, p} W_{v, p}\right) t_{f, p}\right]+Q_{d} W_{f} Q_{f} x_{f} t_{f, f}}{\sum_{p=1}^{S}\left(f_{H, p} Q_{p} t_{f, p}\right)+f_{H, d} Q_{f} W_{f} Q_{d} t_{f, f}}\right\}\right]
\end{gathered}
$$


where

$$
\begin{aligned}
& \mathrm{PDCF}_{\mathrm{AG}, \mathrm{H} 3}=\text { animal product ingestion } \mathrm{PDCF} \text { for }{ }^{3} \mathrm{H}, \mathrm{mrem} / \mathrm{yr} \text { per Ci/g soil; } \\
& 1000=\mathrm{g} / \mathrm{kg} \text {; } \\
& \text { DIET }_{\mathrm{a}} \quad=\quad \text { fraction of annual animal diet derived from contaminated area, } \\
& \text { dimensionless; } \\
& \mathrm{DFG}_{\mathrm{H} 3} \quad=\quad \text { ingestion } \mathrm{DF} \text { for }{ }^{3} \mathrm{H}, \mathrm{mrem} / \mathrm{Ci} \text {; } \\
& \mathrm{U}_{\mathrm{a}, \mathrm{q}} \quad=\quad \text { annual consumption rate of animal product } \mathrm{q}, 1 / \mathrm{yr} \text { for milk and } \mathrm{kg} \\
& \text { (wet)/yr for all other animal products; } \\
& \mathrm{f}_{\mathrm{H}, \mathrm{q}} \quad=\quad \text { mass fraction of } \mathrm{H} \text { in animal product, } \mathrm{kg} \mathrm{H} / \mathrm{kg} \text { (wet) animal } \\
& \text { product; } \\
& \mathrm{SA}_{\mathrm{TaH}}=\text { specific activity equivalence, } \mathrm{Ci} / \mathrm{kg} \mathrm{H} \text { in animal per } \mathrm{Ci} / \mathrm{kg} \mathrm{H} \text { in } \\
& \text { food intake (assumed to be } 1.0 \text { ); } \\
& \mathrm{Q}_{\mathrm{p}} \quad=\quad \text { animal consumption rate of plant } \mathrm{p}, \mathrm{kg} \text { (wet)/d; } \\
& \mathrm{x}_{\mathrm{p}} \quad=\quad \text { fraction of animal intake of plant } \mathrm{p} \text { that is contaminated, } \\
& \text { dimensionless; } \\
& \mathrm{B}_{\mathrm{H} 3, \mathrm{v}, \mathrm{p}}=\text { plant-to-soil concentration ratios for }{ }^{3} \mathrm{H} \text { and plant } \mathrm{p}, \mathrm{Ci} / \mathrm{kg} \text { plant } \\
& \text { (dry) per } \mathrm{Ci} / \mathrm{kg} \text { soil (dry); } \\
& \mathrm{ML}_{\mathrm{v}, \mathrm{p}} \quad=\quad \text { soil mass loading on plant } \mathrm{p} \text { surfaces, } \mathrm{Ci} / \mathrm{kg} \text { plant (dry) per } \mathrm{Ci} / \mathrm{kg} \\
& \text { soil (dry); } \\
& \mathrm{W}_{\mathrm{v}, \mathrm{p}} \quad=\quad \text { dry-to-wet mass ratio for plant type } \mathrm{p} \text {, dimensionless; } \\
& \mathrm{t}_{\mathrm{f}, \mathrm{p}} \quad=\quad \text { time per year animal consumes plant } \mathrm{p}, \mathrm{d} \text {; } \\
& \mathrm{Q}_{\mathrm{d}} \quad=\quad \text { fraction of animal forage intake that is soil, } \mathrm{kg} \text { (dry) soil } / \mathrm{kg} \text { (dry) } \\
& \text { forage; } \\
& \mathrm{W}_{\mathrm{f}} \quad=\quad \text { dry-to-wet mass ratio for forage, dimensionless; } \\
& \mathrm{Q}_{\mathrm{f}} \quad=\quad \text { animal consumption rate of forage, } \mathrm{kg}(\mathrm{wet}) / \mathrm{d} \text {; } \\
& \mathrm{x}_{\mathrm{f}}=\text { fraction of animal intake of forage that is contaminated, } \\
& \text { dimensionless; } \\
& \mathrm{t}_{\mathrm{f}, \mathrm{f}} \quad=\quad \text { time per year animal consumes forage, } \mathrm{d} \text {; } \\
& \mathrm{f}_{\mathrm{H}, \mathrm{p}} \quad=\quad \text { mass fraction of } \mathrm{H} \text { in plant } \mathrm{P}, \mathrm{kg} \mathrm{H} / \mathrm{kg} \text { (wet plant); and } \\
& \mathrm{f}_{\mathrm{H}, \mathrm{d}} \quad=\quad \text { mass fraction of } \mathrm{H} \text { in soil, } \mathrm{kg} \mathrm{H} / \mathrm{kg} \text { (dry) soil. }
\end{aligned}
$$

The animal product ${ }^{3} \mathrm{H}$ ingestion pathway DF is calculated as the product of the fraction of the diet that is home produced, the ingestion DF, the annual consumption rate, the fractional transfer of ${ }^{3} \mathrm{H}$ to plants, and the fraction of tissue $\mathrm{H}$ derived from plant intake. Soil contamination is transferred to the animal product through the ingestion of forage, hay, grain, and soil. Forage, hay, and grain accumulate contamination from root uptake and soil deposition.

The animal product ingestion pathway DF for ${ }^{14} \mathrm{C}$ is calculated using a specific activity model as: 


$$
\begin{gathered}
P D C F_{A G, C 14}=1000 D I E T_{a} D F G_{C l 4} \sum_{q=1}^{R}\left[U_{a, q} f_{C, q} S A_{T a C}\right. \\
\left.\times\left\{\frac{\sum_{p=1}^{S}\left[Q_{p} x_{p}\left(M L_{v, p}+B_{C I 4, v, p}\right) W_{v, p} t_{f, p}\right]+Q_{d} W_{f} Q_{f} x_{f} t_{f, f}}{\sum_{p=1}^{S}\left(f_{C, p} Q_{p} t_{f, p}\right)+f_{C, d} Q_{f} W_{f} Q_{d} t_{f, f}}\right\}\right]
\end{gathered}
$$

where

$$
\begin{aligned}
& \mathrm{PDCF}_{\mathrm{AG}, \mathrm{C} 14}=\quad \text { animal product ingestion } \mathrm{PDCF} \text { for }{ }^{14} \mathrm{C} \text {, in soil, (mrem g) } /(\mathrm{Ci} \mathrm{yr}) ; \\
& 1000=\mathrm{g} / \mathrm{kg} \text {; } \\
& \mathrm{DIET}_{\mathrm{a}}=\text { fraction of annual animal diet derived from contaminated area, } \\
& \text { dimensionless; } \\
& \mathrm{DFG}_{\mathrm{C} 14}=\text { ingestion } \mathrm{DF} \text { for }{ }^{14} \mathrm{C}, \mathrm{mrem} / \mathrm{Ci} \text {; } \\
& \mathrm{U}_{\mathrm{a}, \mathrm{q}} \quad=\quad \text { annual consumption rate of animal product } \mathrm{q}, 1 / \mathrm{yr} \text { for milk and } \mathrm{kg} \\
& \text { (wet)/yr for all other animal products; } \\
& \mathrm{f}_{\mathrm{C}, \mathrm{q}}=\text { mass fraction of } \mathrm{C} \text { in animal product, } \mathrm{kg} \mathrm{C} / \mathrm{kg} \text { (wet) animal } \\
& \text { product; } \\
& \mathrm{SA}_{\mathrm{TaC}}=\text { specific activity equivalence, } \mathrm{Ci} / \mathrm{kg} \mathrm{C} \text { in animal per } \mathrm{Ci} / \mathrm{kg} \mathrm{C} \text { in } \\
& \text { food intake (assumed to be 1.0); } \\
& \mathrm{Q}_{\mathrm{p}} \quad=\quad \text { animal consumption rate of plant } \mathrm{p}, \mathrm{kg}(\mathrm{wet}) / \mathrm{d} \text {; } \\
& \mathrm{x}_{\mathrm{p}} \quad=\quad \text { fraction of animal intake of plant } \mathrm{p} \text { that is contaminated, } \\
& \text { dimensionless; } \\
& \mathrm{ML}_{\mathrm{v}, \mathrm{p}} \quad=\quad \text { soil mass loading on plant } \mathrm{p} \text { surfaces, } \mathrm{Ci} / \mathrm{kg} \text { plant (dry) per } \mathrm{Ci} / \mathrm{kg} \\
& \text { soil (dry); } \\
& \mathrm{B}_{\mathrm{Cl} 14, \mathrm{v}, \mathrm{p}}=\text { plant-to-soil concentration ratios for }{ }^{14} \mathrm{C} \text { and plant } \mathrm{p}, \mathrm{Ci} / \mathrm{kg} \text { plant } \\
& \text { (dry) per } \mathrm{Ci} / \mathrm{kg} \text { soil (dry); } \\
& \mathrm{W}_{\mathrm{v}, \mathrm{p}} \quad=\quad \text { dry-to-wet mass ratio for plant type } \mathrm{p} \text {, dimensionless; } \\
& \mathrm{t}_{\mathrm{f}, \mathrm{p}} \quad=\quad \text { time per year animal consumes plant } \mathrm{p}, \mathrm{d} \text {; } \\
& \mathrm{Q}_{\mathrm{d}} \quad=\quad \text { fraction of animal forage intake that is soil, } \mathrm{kg} \text { (dry) soil } / \mathrm{kg} \text { (dry) } \\
& \text { forage; } \\
& \mathrm{W}_{\mathrm{f}} \quad=\quad \text { dry-to-wet mass ratio for forage, dimensionless; } \\
& \mathrm{Q}_{\mathrm{f}} \quad=\quad \text { animal consumption rate of forage, } \mathrm{kg}(\mathrm{wet}) / \mathrm{d} \text {; } \\
& \mathrm{x}_{\mathrm{f}}=\text { fraction of animal intake of forage that is contaminated, } \\
& \text { dimensionless; } \\
& t_{f, f} \quad=\quad \text { time per year animal consumes forage, } d \text {; } \\
& \mathrm{f}_{\mathrm{C}, \mathrm{p}} \quad=\quad \text { mass fraction of } \mathrm{C} \text { in plant } \mathrm{p}, \mathrm{kg} \mathrm{H} / \mathrm{kg} \text { (wet) plant; and } \\
& \mathrm{f}_{\mathrm{C}, \mathrm{d}}=\text { mass fraction of } \mathrm{C} \text { in soil, } \mathrm{kg} \mathrm{C} / \mathrm{kg} \text { (dry) soil. }
\end{aligned}
$$


The animal product ${ }^{14} \mathrm{C}$ ingestion pathway $\mathrm{DF}$ is calculated as the product of the fraction of the diet that is home-produced, the ingestion DF, the annual consumption rate, the fractional transfer of ${ }^{14} \mathrm{C}$ to plants, and the fraction of tissue $\mathrm{C}$ derived from plant intake. Soil contamination is transferred to the animal product through the ingestion of forage, hay, grain, and soil. Forage, hay, and grain accumulate contamination from root uptake, $\mathrm{CO}_{2}$ fixation, and soil deposition.

\section{A3.1.4 Converting Radionuclide Concentrations into Total Effective Dose Equivalent}

The TEDE is calculated as the product of the SDCF and the environmental concentration of the radionuclide. The SDCF is the sum of all the individual PDCFs for the same contaminated environmental medium. The SDCF is specific to a radionuclide, exposure medium, and exposure scenario.

\section{A3.1.4.1 Calculation of the Scenario Dose Conversion Factors}

The CA uses a single exposure scenario that assumes a residential exposure of a member of a small rural community. Scenario dose conversions factors must be calculated for a single exposure scenario (residential), two exposure media (soil and air), and each radionuclide.

The SDCF for soil is the sum of the PDCFs for inhalation of soil particulates, external irradiation, soil ingestion, vegetable ingestion, and animal product ingestion. The soil SDCF is calculated as:

$$
S D C F_{s, j}=P D C F_{H, j}+P D C F_{E X, j}+P D C F_{G S, j}+P D C F_{V G, j}+P D C F_{A G, j}
$$

where

$$
\mathrm{SDCF}_{\mathrm{s}, \mathrm{j}}=\begin{aligned}
& \text { scenario dose conversion factor for radionuclide } \mathrm{j} \text { in soil, } \\
& (\mathrm{mrem} \mathrm{g}) /(\mathrm{Ci} \mathrm{yr}) .
\end{aligned}
$$

The SDCF for nonvolatile radionuclides in air is equal to the PDCF for airborne soil inhalation. The SDCF for nonvolatile radionuclides in air is calculated as:

$$
S D C F_{A N, j}=P D C F_{A, j}
$$

where

$$
\begin{aligned}
\mathrm{SDCF}_{\mathrm{AN}, \mathrm{j}}=\quad \begin{array}{l}
\text { scenario dose conversion factor for nonvolatile radionuclide } \mathrm{j} \text { in } \\
\text { air, } \left.(\mathrm{mrem} \mathrm{m})^{3}\right) /(\mathrm{Ci} \mathrm{yr}) .
\end{array}
\end{aligned}
$$


The SDCF for volatile radionuclides in air is equal to the sum of the PDCFs for gas immersion and inhalation. The SDCF for volatile radionuclides in air is calculated as:

$$
S D C F_{A V, j}=P D C F_{G H, j}+P D C F_{I M, j}
$$

where

$$
\begin{aligned}
\mathrm{SDCF}_{\mathrm{AV}, \mathrm{j}}=\quad \begin{array}{l}
\text { scenario dose conversion factor for volatile radionuclides } \mathrm{j} \text { in air, } \\
\left(\mathrm{mrem} \mathrm{m} \mathrm{m}^{3}\right) /(\mathrm{Ci} \mathrm{yr}) .
\end{array}
\end{aligned}
$$

\section{A3.1.4.2 Calculation of the Total Effective Dose Equivalent}

Members of the public are assumed to be exposed as residents of a small rural community in Frenchman Flat. The TEDE for a resident of Frenchman Flat is calculated as:

$T E D E(t)=\sum_{j=1}^{M}\left[C_{s, j}(t) S D C F_{s, j}+C_{A N_{j}}(t) S D C F_{A N_{j} j}+C_{A V_{j}}(t) S D C F_{A V, j}\right]$

where

$$
\begin{aligned}
& \operatorname{TEDE}(\mathrm{t})=\text { annual total effective dose equivalent at time } \mathrm{t} \text {, } \mathrm{mrem} / \mathrm{yr} \text {; } \\
& \mathrm{C}_{\mathrm{s}, \mathrm{j}}(\mathrm{t})=\text { soil concentration of radionuclide } \mathrm{j}, \mathrm{Ci} / \mathrm{g} \text {; } \\
& \mathrm{C}_{\mathrm{AN}, \mathrm{j}}(\mathrm{t})=\text { atmospheric concentration of nonvolatile radionuclide } \mathrm{j}, \mathrm{Ci} / \mathrm{m}^{3} \text {, } \\
& \text { and; } \\
& \mathrm{C}_{\mathrm{AV}, \mathrm{j}}(\mathrm{t})=\text { atmospheric concentration of volatile radionuclide } \mathrm{j}, \mathrm{Ci} / \mathrm{m}^{3} \text {. }
\end{aligned}
$$

The media concentrations are derived from transport models described in Appendix 2 and vary with location and time. Concentrations are calculated for four sites: the Area 5 Radioactive Waste Management Site (RWMS), Frenchman Flat playa soil site; Gadgets, Mechanics, and Explosives (GMX) soil site; and all other off-site locations that are not a source term.

The nonvolatile radionuclide concentrations in air are calculated by the ISCLT model at all locations. The Area 5 RWMS is the only source of volatile radionuclides. The volatile radionuclide concentrations at the Area 5 RWMS are calculated using the volatile radionuclide 
release model as described in Appendix 2. The volatile radionuclide fluxes from the Area 5 RWMS are used with the ISCLT model to estimate volatile radionuclide concentrations at all locations beyond the Area 5 RWMS.

The soil concentration at locations not in a contaminated source term are calculated from the ISCLT deposition rates and Equation A2.34 in Appendix 2. The soil concentration at the Area 5 RWMS is obtained from the nonvolatile radionuclide transport model. The soil concentrations at Frenchman Flat playa soil site and the GMX soil site are calculated from the Radionuclide Inventory and Distribution Program (RIDP) site characterization data (McArthur, 1991) described in Chapter 4. The RIDP inventory data, for all nuclides except ${ }^{241} \mathrm{Am}$, were converted to concentration as:

$$
C_{s, j}(t)=\frac{I_{j} \alpha e^{-\lambda_{j} t}}{A \rho_{s}}
$$

where

$$
\begin{array}{lll}
\mathrm{C}_{\mathrm{s}, \mathrm{j}}(\mathrm{t}) & = & \text { soil concentration of radionuclide } \mathrm{j}, \mathrm{Ci} / \mathrm{g} ; \\
\mathrm{I}_{\mathrm{j}} & = & \text { soil inventory of radionuclide } \mathrm{j}, \mathrm{Ci} ; \\
\alpha & = & \text { inverse relaxation length, } \mathrm{m}^{-1} ; \\
\lambda_{\mathrm{j}} \mathrm{t} & = & \text { radioactive decay constant of radionuclide } \mathrm{j}, \mathrm{yr}^{-1} ; \\
\mathrm{A} & = & \text { contamination area, } \mathrm{m}^{2} ; \text { and } \\
\rho_{\mathrm{s}} & = & \text { soil density, } \mathrm{g} / \mathrm{m}^{3} .
\end{array}
$$

For ${ }^{241} \mathrm{Am}$, the soil concentration was calculated as:

$$
C_{s, A m 24 I}(t)=\frac{\alpha}{A \rho_{s}}\left\lfloor I_{2} e^{-\lambda_{2} t}+\frac{I_{1} \lambda_{2}}{\lambda_{2}-\lambda_{1}}\left(e^{-\lambda_{1} t}-e^{-\lambda_{2} t}\right) \mid\right.
$$

where

$$
\begin{array}{ll}
\mathrm{I}_{1} & =\text { the } \\
\mathrm{I}_{2} & =\text { the } \\
\lambda_{1} & =\text { the } \mathrm{e}^{241} \mathrm{Am} \text { inventory }, \mathrm{Ci} ; \\
\lambda_{2} & =\quad \text { the decay constant, } \mathrm{yr}^{-1} ; \text { and }
\end{array}
$$

The equations above estimate the area weighted mean concentration averaged over the characterized area. The model assumes that the only process affecting soil concentration over 
time is radioactive decay. The ingrowth of progeny is assumed to be negligible for all nuclides except ${ }^{241} \mathrm{Pu}$. Ingrowth of ${ }^{241} \mathrm{Am}$ from ${ }^{241} \mathrm{Pu}$ is calculated explicitly.

\section{A3.1.5 Selection of Parameter Values}

The parameter values selected are described in Tables A3.1 through A3.4. Three sets of SDCFs are estimated in Tables A3.5 and A3.6 for the three media: soil, nonvolatile radionuclides in air, and volatile radionuclides in air.

Variables having significant uncertainty are treated as random variables below, except for those used in the agricultural pathways. In most cases, there is insufficient data to determine the statistical distribution of the parameter. Parameters where only a range could be identified were assigned uniform distributions. Parameters with sufficient data to estimate an expected value and a range were assigned triangular distributions.

\section{A3.1.5.1 Soil Inhalation Pathway}

Mass loading is estimated for three locations (outdoors, indoors, and in the garden). The distribution of outdoor particulate mass loading is based on observed $\mathrm{PM}_{10}$ values for the Las Vegas Valley (Clark County Health District, 1997). The data are annual mean $\mathrm{PM}_{10}$ values for the Las Vegas Valley. The $\mathrm{PM}_{10}$ is the concentration of particulate matter with an aerodynamic diameter less than or equal to $10 \mu \mathrm{m}$. The inhalation DF assumes particulate matter with an activity median aerodynamic diameter of $1 \mu \mathrm{m}$. Under this assumption, $\mathrm{PM}_{10}$ is likely to be a conservative estimate of the particulate matter available for deposition in the deep pulmonary region. Particulates greater than $10 \mu \mathrm{m}$ will be deposited mostly in the nasopharyngeal $(\mathrm{N}-\mathrm{P})$ region (ICRP, 1979). Adsorption of the greater-than-10 $\mu \mathrm{m}$ fraction may occur in the N-P region or after transport through the gut. Radionuclides in these larger particulates will be absorbed in accordance with the $f_{1}$ value assumed for the element...The $f_{1}$ value is the fraction of the ingested element that is transferred to the body fluids (ICRP, 1979). The mass of soil that may be deposited in the N-P region from inhalation and ultimately absorbed is very small compared to the quantity inadvertently ingested. Therefore, inhalation of particulates greater than $10 \mu \mathrm{m}$ can be ignored. Mass loading in Las Vegas is higher than in surrounding rural areas. Shinn et al. (1986) reported mass loading values for several locations on the NTS ranging from 7e-6 to $4.1 \mathrm{e}-5$ $\mathrm{g} / \mathrm{m}^{3}$, which are slightly less than the $\mathrm{PM}_{10}$ data for Las Vegas. The Las Vegas data are assumed for the analysis and are assumed to include the effects of mechanical resuspension that will occur with development. The distribution is assumed to be approximated by a normal distribution. The mean and standard deviation of the data set are $4.58 \mathrm{e}-5$ and $7.20 \mathrm{e}-6 \mathrm{~g} / \mathrm{m}^{3}$, respectively. The enrichment factor is assumed to be 1.0 for all sites.

Indoor mass loading has been calculated as the product of indoor soil contamination derived from outdoor sources and a resuspension factor. Layton et al. (1993) has reported that the loading of soil-derived dust in dwellings ranges from 0.136 to $0.870 \mathrm{~g} / \mathrm{m}^{2}$, with a geometric mean of $0.42 \mathrm{~g} / \mathrm{m}^{2}$. A fixed resuspension factor of $5 \mathrm{e}-5 \mathrm{~m}^{-1}$ is assumed (Kennedy and Strenge, 1992). 


\section{Table A3.1 Parameter Values for Nonagricultural Pathways}

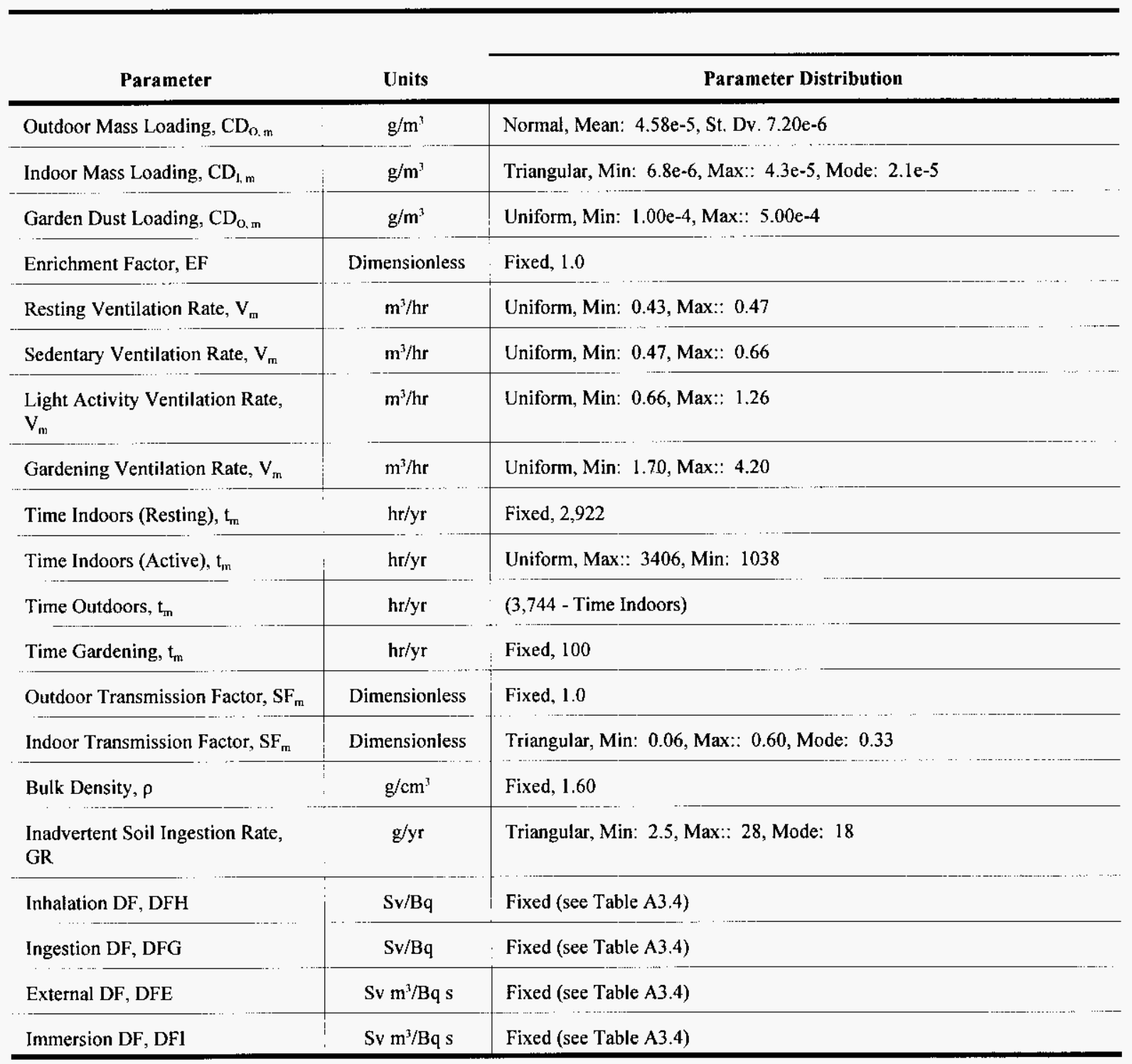


Table A3.2 Agricultural Pathway Parameters for Water-Independent Pathways

\begin{tabular}{|c|c|c|c|}
\hline Parameter & Units & Value & Source \\
\hline Gravimetric Moisture Content, $\mathrm{S}_{\mathrm{H}}$ & $\mathrm{g} / \mathrm{g}$ & $\therefore \quad 0.13$ & Bechtel Nevada (1996a,b; 1997) \\
\hline Leafy Plant Mass Loading, $M_{v, p}$ & kg (dry) soil/kg (dry) plant & 0.1 & Martin and Bloom (1980) \\
\hline Other Plant Mass Loading, $\mathrm{ML}_{\mathrm{r}, \mathrm{p}}$ & $\mathrm{kg}$ (dry) soil/kg (dry) plant & 0.01 & $\begin{array}{l}\text { Martin and Bloom (1980), Kennedy and } \\
\text { Strenge (1992) }\end{array}$ \\
\hline Leafy Veg. Dry/Wet Ratio, $W_{v, p}$ & $\mathrm{~kg}($ dry $) / \mathrm{kg}$ (wet) & 0.2 & Kennedy and Strenge (1992) \\
\hline Other Veg. Dry/Wet Ratio, $W_{v, p}$ & $\mathrm{~kg}$ (dry) $/ \mathrm{kg}$ (wet) & 0.25 & Kennedy and Strenge (1992) \\
\hline Fruit Dry/Wet Ratio, $\mathrm{W}_{\mathrm{v}, \mathrm{p}}$ & $\mathrm{kg}($ dry $) / \mathrm{kg}($ wet $)$ & 0.18 & Kennedy and Strenge (1992) \\
\hline Grain Dry/Wet Ratio, $W_{v, p}$ & $\mathrm{~kg}(\mathrm{dry}) / \mathrm{kg}($ wet $)$ & 0.91 & Kennedy and Strenge (1992) \\
\hline Leafy Veg. Fraction $\mathrm{H}, \mathrm{f}_{1 \mathrm{l}, \mathrm{p}}$ & $\mathrm{kg} \mathrm{H} / \mathrm{kg}$ (wet) plant & 0.1 & Kennedy and Strenge (1992) \\
\hline Other Veg. Fraction $\mathrm{H}, \mathrm{f}_{\mathrm{Hi}, \mathrm{p}}$ & $\mathrm{kg} \mathrm{H} / \mathrm{kg}$ (wet) plant & 0.1 & Kennedy and Strenge (1992) \\
\hline Fruit Fraction $\mathrm{H}, \mathbf{f}_{\mathrm{IL} . \mathrm{p}}$ & $\mathrm{kg} \mathrm{H} / \mathrm{kg}$ (wet) plant & 0.1 & Kennedy and Strenge (1992) \\
\hline Grain Fraction $\mathbf{H}, \mathrm{f}_{\mathrm{II}, \mathrm{p}}$ & $\mathrm{kg} \mathrm{H} / \mathrm{kg}$ (wet) plant & 0.068 & Kennedy and Strenge (1992) \\
\hline Soil Fraction $\mathrm{H}, \mathbf{f}_{\mathrm{Fl} . \mathrm{d}}$ & $\mathrm{kg} \mathrm{H} / \mathrm{kg}$ wet soil & 0.014 & Gravimetric Water Content/9 \\
\hline Forage/Hay Fraction $\mathrm{C}, \mathrm{f}_{\mathrm{C}, \mathrm{p}}$ & $\mathrm{kg} \mathrm{C} / \mathrm{kg}$ (wet) forage & 0.09 & Kennedy and Strenge (1992) \\
\hline Grain Fraction $\mathrm{C}, \mathbf{f}_{\mathrm{c}, \mathrm{p}}$ & $\mathrm{kg} \mathrm{C} / \mathrm{kg}$ (wet) grain & 0.4 & Kennedy and Strenge (1992) \\
\hline Cattle Forage Consumption Rate, $\mathrm{Q}_{\mathrm{p}}$ & $\mathrm{kg}$ (wet)/day & 30 & Martin and Bloom (1980) \\
\hline Cattle Grain Consumption Rate, $\mathrm{Q}_{\mathrm{p}}$ & $\mathrm{kg}$ (wet)/day & 3 & Kennedy and Strenge (1992) \\
\hline Cattle Hay Consumption Rate, $Q_{p}$ & $\mathrm{~kg}$ (wet)/day & 14 & Kennedy and Strenge (1992) \\
\hline Fraction of Cattle Forage as Soil, $\mathrm{Q}_{\mathrm{d}}$ & $\mathrm{kg}$ (dry)soil/kg (dry) forage & 0.063 & Smith (1977) \\
\hline Poultry Forage Consumption Rate, $\mathrm{Q}_{\mathrm{p}}$ & $\mathrm{kg}$ (wet)/day & 0.13 & Kennedy and Strenge (1992) \\
\hline Poultry Grain Consumption Rate, $\mathrm{Q}_{\mathrm{p}}$ & $\mathrm{kg}(\mathrm{wet}) / \mathrm{day}$ & 0.09 & Kennedy and Strenge (1992) \\
\hline Poultry Hay Consumption Rate, $\mathrm{Q}_{\mathrm{p}}$ & $\mathrm{kg}($ wet $) /$ day & 0 & Kennedy and Strenge (1992) \\
\hline Fraction of Poultry Forage as Soil, $\mathrm{Q}_{\mathrm{d}}$ & $\mathrm{kg}$ (dry)soil/kg (dry) forage & 0.1 & Kennedy and Strenge (1992) \\
\hline Days Cattle Consume Forage, $t_{f, f}$ & days/yr & 365.25 & Kennedy and Strenge (1992) \\
\hline Days Cattle Consume Grain, $t_{c_{1}}$ & days/yr & 365.25 & Kennedy and Strenge (1992) \\
\hline Days Cattle Consume Hay, $\mathrm{t}_{\mathrm{t}, \mathrm{p}}$ & days/yr & 365.25 & Kennedy and Strenge (1992) \\
\hline Days Poultry Consume Forage, $t_{t, i}$ & days/yr & 365.25 & Kennedy and Strenge (1992) \\
\hline Days Poultry Consume Grain, $t_{t_{\text {. }}}$ & days/yr & 365.25 & Kennedy and Strenge (1992) \\
\hline Days Poultry Consume Hay, $t_{f, p}$ & days/yr & 365.25 & Kennedy and Strenge (1992) \\
\hline $\begin{array}{l}\text { Fraction of Cattle Forage Intake } \\
\text { Contaminated, } x_{f}\end{array}$ & Dimensionless & 0.04 & Richard-Haggard (1983) \\
\hline
\end{tabular}


Table A3.2 (continued)

\begin{tabular}{|c|c|c|c|}
\hline Parameter & Units & Value & Source \\
\hline $\begin{array}{l}\text { Fraction of Cattle Grain Intake } \\
\text { Contaminated, } x_{p}\end{array}$ & Dimensionless & 0 & Scenario Assumption \\
\hline $\begin{array}{l}\text { Fraction of Cattle Hay Intake } \\
\text { Contaminated, } x_{p}\end{array}$ & Dimensionless & 0 & Scenario Assumption \\
\hline $\begin{array}{l}\text { Fraction of Poultry Forage Intake } \\
\text { Contaminated, } x_{i}\end{array}$ & Dimensionless & 1 & Scenario Assumption \\
\hline $\begin{array}{l}\text { Fraction of Poultry Grain Intake } \\
\text { Contaminated, } x_{p}\end{array}$ & Dimensionless & 0 & Scenario Assumption \\
\hline $\begin{array}{l}\text { Fraction of Poultry Hay Intake } \\
\text { Contaminated, } x_{p}\end{array}$ & Dimensionless & 0 & Scenario Assumption \\
\hline Fraction of Beef as $\mathrm{H}, \mathrm{f}_{1 \mathrm{in}, 4}$ & $\mathrm{~kg} \mathrm{H} / \mathrm{kg}$ (wet) product & 0.1 & Kennedy and Strenge (1992) \\
\hline Fraction of Milk as $\mathrm{H}, \mathrm{f}_{\mathrm{H}, \mathrm{q}}$ & $\mathrm{kg} \mathrm{H} / \mathrm{kg}$ (wet) product & 0.11 & Kennedy and Strenge (1992) \\
\hline Fraction of Poultry as $\mathrm{H}, \mathrm{f}_{\mathrm{H}, \mathrm{q}}$ & $\mathrm{kg} \mathrm{H} / \mathrm{kg}$ (wet) product & 0.1 & Kennedy and Strenge (1992) \\
\hline Fraction of Eggs as $\mathrm{H}, \mathrm{f}_{\mathrm{H}, \mathrm{q}}$ & $\mathrm{kg} \mathrm{H} / \mathrm{kg}$ (wet) product & 0.11 & Kennedy and Strenge (1992) \\
\hline Fraction of Beef as $\mathrm{C}, \mathrm{f}_{\mathrm{c} \cdot \mathrm{q}}$ & $\mathrm{kg} \mathrm{C} / \mathrm{kg}$ (wet) product & 0.24 & Kennedy and Strenge (1992) \\
\hline Fraction of Milk as $\mathrm{C}, \mathrm{f}_{\mathrm{C}, \mathrm{q}}$ & $\mathrm{kg} \mathrm{C} / \mathrm{kg}$ (wet) product & $\therefore \quad 0.07$ & Kennedy and Strenge (1992) \\
\hline Fraction of Poultry as $\mathrm{C}, \mathrm{f}_{\mathrm{C}, 4}$ & $\mathrm{~kg} \mathrm{C} / \mathrm{kg}$ (wet) product & 0.2 & Kennedy and Strenge (1992) \\
\hline Fraction of Eggs as $\mathrm{C}, \mathrm{f}_{\mathrm{C}, \mathrm{q}}$ & $\mathrm{kg} \mathrm{C} / \mathrm{kg}$ (wet) product & 0.15 & Kennedy and Strenge (1992) \\
\hline Soil Fraction $\mathrm{C}, \mathrm{f}_{\mathrm{c}, \mathrm{d}}$ & $\mathrm{kg} \mathrm{C} / \mathrm{kg}$ (wet) soil & 0.03 & Kennedy and Strenge (1992) \\
\hline $\begin{array}{l}\text { Resident Leafy Veg. Consumption, } \\
\mathrm{U}_{\mathrm{v}, \mathrm{p}}\end{array}$ & $\mathrm{kg}($ wet $) / \mathrm{yr}$ & 18 & Rupp (1980) \\
\hline Resident Other Veg. Consumption, $\mathrm{U}_{\mathrm{v}, \mathrm{p}}$ & $\mathrm{kg}($ wet $) / \mathrm{yr}$ & 73 & Rupp (1980) \\
\hline Resident Fruit Consumption, $\mathrm{U}_{\mathrm{v}, \mathrm{p}}$ & $\mathrm{kg}($ wet $) / \mathrm{yr}$ & 68 & Rupp (1980) \\
\hline Resident Grain Consumption, $\mathrm{U}_{v, \mathrm{p}}$ & $\mathrm{kg}(\mathrm{wet}) / \mathrm{yr}$ & 0 & Rupp (1980) \\
\hline Resident Beef Consumption, $\mathrm{U}_{\mathrm{a}, \mathrm{q}}$ & $\mathrm{kg}(\mathrm{wet}) / \mathrm{yr}$ & 31 & Rupp (1980) \\
\hline Resident Milk Consumption, $\mathrm{U}_{\mathrm{a}, \mathrm{4}}$ & $\mathrm{kg}$ (wet)/yr & 95 & Rupp (1980) \\
\hline Resident Poultry Consumption, $\mathrm{U}_{\mathrm{a}, q}$ & $\mathrm{~kg}($ wet $) / \mathrm{yr}$ & 9.5 & Rupp (1980) \\
\hline Resident Eggs Consumption, $\mathrm{U}_{\mathrm{a}, \mathrm{q}}$ & $\mathrm{kg}($ wet $) / \mathrm{yr}$ & 15 & Rupp (1980) \\
\hline $\begin{array}{l}\text { Fraction of Veg. Diet Produced on Site, } \\
\text { DIET }_{r}\end{array}$ & Dimensionless & $\begin{array}{l}\text { Uniform, } \\
\text { Min.: } 0.0 \\
\text { Max.: } 0.2\end{array}$ & $\begin{array}{l}\text { U.S. Environmental Protection Agency } \\
\text { (EPA) (1989) }\end{array}$ \\
\hline $\begin{array}{l}\text { Fraction of Animal Products Produced on } \\
\text { Site, DIET }\end{array}$ & Dimensionless & $\begin{array}{cc}\text { Uniform } \\
\text { Min.: } 0.0 \\
\text { Max.: } & 0.4\end{array}$ & EPA (1989) \\
\hline
\end{tabular}


Table A3.3 Dry Plant-Soil Concentration Ratios and Animal Product Transfer Factors (from Kennedy and Strenge, 1992)

\begin{tabular}{|c|c|c|c|c|c|c|c|c|}
\hline Element & $\begin{array}{c}\text { B }_{\text {jv Leafy Veg. }} \\
\mathrm{Ci} / \mathrm{kg} \text { (dry) Plant } \\
\text { per Ci/kg (dry) } \\
\text { Soil }\end{array}$ & $\begin{array}{c}B_{\text {jv }} \text { Root } \\
\text { Ci/kg (dry) } \\
\text { Plant per } \\
\text { Ci/kg (dry) } \\
\text { Soil } \\
\end{array}$ & $\begin{array}{c}\text { B }_{\text {jy }} \text { Fruit } \\
\text { Ci/kg (dry) } \\
\text { Plant per } \\
\text { Ci/kg (dry) } \\
\text { Soil } \\
\end{array}$ & $\begin{array}{c}\text { B }_{\text {jv }} \text { Grain } \\
\text { Ci/kg (dry) } \\
\text { Plant per } \\
\text { Ci/kg (dry) } \\
\text { Soil } \\
\end{array}$ & $\begin{array}{c}\text { F }_{\mathrm{a}, \mathrm{j}, \mathrm{q}} \text { Beef } \\
\text { Transfer } \\
\text { Factor } \\
(\mathrm{d} / \mathrm{kg})\end{array}$ & $\begin{array}{c}\text { F }_{\mathrm{a}, \mathrm{j}, \mathrm{u}} \text { Poultry } \\
\text { Transfer } \\
\text { Factor } \\
(\mathbf{d} / \mathbf{k g})\end{array}$ & $\begin{array}{c}\text { F }_{\mathrm{a}, \mathrm{j}, \mathrm{q}} \text { Milk } \\
\text { Transfer Factor } \\
(\mathbf{d} / \mathbf{)})\end{array}$ & $\begin{array}{c}\mathbf{F}_{\mathrm{a}, \mathrm{j}, \mathrm{q}} \mathbf{E g g} \\
\text { Transfer Factor } \\
(\mathbf{d} / \mathbf{k g}) \\
\end{array}$ \\
\hline $\mathbf{H}^{\dagger}$ & $6.92 \mathrm{e}+00$ & $6.92 \mathrm{e}+00$ & $6.92 \mathrm{e}+00$ & $4.71 e+00$ & $\ddagger$ & $\ddagger$ & $\ddagger$ & $\ddagger$ \\
\hline $\mathrm{Be}$ & $1.00 \mathrm{e}-02$ & $1.50 \mathrm{e}-03$ & $1.50 \mathrm{e}-03$ & $1.50 \mathrm{e}-03$ & $1.00 \mathrm{e}-03$ & $4.00 \mathrm{e}-01$ & $9.00 \mathrm{e}-07$ & $2.00 \mathrm{e}-02$ \\
\hline $\mathrm{C}$ & $7.00 \mathrm{e}-01$ & $7.00 \mathrm{e}-01$ & $7.00 \mathrm{e}-01$ & $7.00 \mathrm{e}-01$ & $\ddagger$ & + & $\ddagger$ & $\ddagger$ \\
\hline $\mathrm{Al}^{8}$ & $4.00 \mathrm{e}-03$ & $4.00 \mathrm{e}-03$ & $4.00 \mathrm{e}-03$ & $4.00 \mathrm{e}-03$ & $5.00 \mathrm{e}-04$ & $3.00 \mathrm{e}-01$ & $2.00 \mathrm{e}-04$ & $8.00 \mathrm{e}-01$ \\
\hline $\mathrm{Cl}$ & $7.00 \mathrm{e}+01$ & $7.00 \mathrm{e}+01$ & $7.00 \mathrm{e}+01$ & $7.00 \mathrm{e}+01$ & $8.00 \mathrm{e}-02$ & $3.00 \mathrm{e}-02$ & $1.50 \mathrm{e}-02$ & $2.00 \mathrm{e}+00$ \\
\hline $\mathrm{Ar}$ & $0.00 \mathrm{e}+00$ & $0.00 \mathrm{e}+00$ & $0.00 \mathrm{e}+00$ & $0.00 \mathrm{e}+00$ & $0.00 \mathrm{e}+00$ & $0.00 \mathrm{e}+00$ & $0.00 \mathrm{e}+00$ & $0.00 \mathrm{e}+00$ \\
\hline $\mathrm{K}$ & $1.00 \mathrm{e}+00$ & $5.50 \mathrm{e}-01$ & $5.50 \mathrm{e}-01$ & $5.50 \mathrm{e}-01$ & $2.00 \mathrm{e}-02$ & $4.00 \mathrm{e}-01$ & $7.00 \mathrm{e}-03$ & $7.00 \mathrm{e}-01$ \\
\hline $\mathrm{Ca}$ & $3.50 \mathrm{e}+00$ & $3.50 \mathrm{e}-01$ & $3.50 \mathrm{e}-01$ & $3.50 \mathrm{e}-01$ & $7.00 \mathrm{e}-04$ & $4.40 \mathrm{e}-02$ & $1.00 \mathrm{e}-02$ & $4.40 \mathrm{e}-01$ \\
\hline $\mathrm{Ni}$ & $2.80 \mathrm{e}-01$ & $6.00 \mathrm{e}-02$ & $6.00 \mathrm{e}-02$ & $3.00 \mathrm{e}-02$ & $6.00 \mathrm{e}-03$ & $1.00 \mathrm{e}-03$ & $1.00 \mathrm{e}-03$ & $1.00 \mathrm{e}-01$ \\
\hline $\mathrm{Co}$ & $8.10 \mathrm{e}-02$ & $4.00 \mathrm{e}-02$ & $7.00 \mathrm{e}-03$ & $3.70 \mathrm{e}-03$ & $2.00 \mathrm{e}-02$ & $5.00 \mathrm{e}-01$ & $2.00 \mathrm{e}-03$ & $1.00 \mathrm{e}-01$ \\
\hline $\mathrm{Kr}$ & $0.00 \mathrm{e}+00$ & $0.00 \mathrm{e}+00$ & $0.00 \mathrm{e}+00$ & $0.00 \mathrm{e}+00$ & $0.00 \mathrm{e}+00$ & $0.00 \mathrm{e}+00$ & $0.00 \mathrm{e}+00$ & $0.00 \mathrm{e}+00$ \\
\hline $\mathrm{Se}$ & $2.50 \mathrm{e}-02$ & $2.50 \mathrm{e}-02$ & $2.50 \mathrm{e}-02$ & $2.50 \mathrm{e}-02$ & $1.50 \mathrm{e}-02$ & $8.50 \mathrm{e}+00$ & $4.00 \mathrm{e}-03$ & $9.30 \mathrm{e}+00$ \\
\hline $\mathrm{Rb}$ & $1.50 \mathrm{e}-01$ & $7.00 \mathrm{e}-02$ & $7.00 \mathrm{e}-02$ & $7.00 \mathrm{e}-02$ & $1.50 \mathrm{e}-02$ & $2.00 \mathrm{e}+00$ & $1.00 \mathrm{e}-02$ & $3.00 \mathrm{e}+00$ \\
\hline $\mathrm{Sr}$ & $1.60 \mathrm{e}+00$ & $8.10 \mathrm{e}-01$ & $1.70 \mathrm{e}-01$ & $1.30 \mathrm{e}-01$ & $3.00 \mathrm{e}-04$ & $3.50 \mathrm{e}-02$ & $1.50 \mathrm{e}-03$ & $3.00 \mathrm{e}-01$ \\
\hline $\mathrm{Zr}$ & $2.00 \mathrm{e}-03$ & $5.00 \mathrm{e}-04$ & $5.00 \mathrm{e}-04$ & $5.00 \mathrm{e}-04$ & $5.50 \mathrm{e}-03$ & $6.40 \mathrm{e}-05$ & $3.00 \mathrm{e}-05$ & $1.90 \mathrm{e}-04$ \\
\hline $\mathrm{Nb}$ & $2.00 \mathrm{e}-02$ & $5.00 \mathrm{e}-03$ & $5.00 \mathrm{e}-03$ & $5.00 \mathrm{e}-03$ & $2.50 \mathrm{e}-01$ & $3.10 \mathrm{e}-04$ & $2.00 \mathrm{e}-02$ & $1.30 \mathrm{e}-03$ \\
\hline $\mathrm{Tc}$ & $4.40 \mathrm{e}+01$ & $1.10 \mathrm{e}+00$ & $1.50 \mathrm{e}+00$ & $7.30 \mathrm{e}-01$ & $8.50 \mathrm{e}-03$ & $3.00 \mathrm{e}-02$ & $1.00 \mathrm{e}-02$ & $3.00 \mathrm{e}+00$ \\
\hline $\mathrm{Pd}$ & $1.50 \mathrm{e}-01$ & $4.00 \mathrm{e}-02$ & $4.00 \mathrm{e}-02$ & $4.00 \mathrm{e}-02$ & $4.00 \mathrm{e}-03$ & $3.00 \mathrm{e}-04$ & $1.00 \mathrm{e}-02$ & $4.00 \mathrm{e}-03$ \\
\hline $\mathrm{Cd}$ & $5.50 \mathrm{e}-01$ & $1.50 \mathrm{e}-01$ & $1.50 \mathrm{e}-01$ & $1.50 \mathrm{e}-01$ & $5.50 \mathrm{e}-04$ & $8.40 \mathrm{e}-01$ & $1.00 \mathrm{e}-03$ & $1.00 \mathrm{e}-01$ \\
\hline $\mathrm{Sn}$ & $3.00 \mathrm{e}-02$ & $6.00 \mathrm{e}-03$ & $6.00 \mathrm{e}-03$ & $6.00 \mathrm{e}-03$ & $8.00 \mathrm{e}-02$ & $2.00 \mathrm{e}-01$ & $1.00 \mathrm{e}-03$ & $8.00 \mathrm{e}-01$ \\
\hline I & $3.40 \mathrm{e}-03$ & $5.00 \mathrm{e}-02$ & $5.00 \mathrm{e}-02$ & $5.00 \mathrm{e}-02$ & $7.00 \mathrm{e}-03$ & $1.80 \mathrm{e}-02$ & $1.00 \mathrm{e}-02$ & $2.80 \mathrm{e}+00$ \\
\hline $\mathrm{Cs}$ & $1.30 \mathrm{e}-01$ & $4.90 \mathrm{e}-02$ & $2.20 \mathrm{e}-01$ & $2.60 \mathrm{e}-02$ & $2.00 \mathrm{e}-02$ & $4.40 \mathrm{e}+00$ & $7.00 \mathrm{e}-03$ & $4.90 \mathrm{e}-01$ \\
\hline $\mathrm{Ba}$ & $1.50 \mathrm{e}-01$ & $1.50 \mathrm{e}-02$ & $1.50 \mathrm{e}-02$ & $1.50 \mathrm{e}-02$ & $1.50 \mathrm{e}-04$ & $8.10 \mathrm{e}-04$ & $3.50 \mathrm{e}-04$ & $1.50 \mathrm{e}+00$ \\
\hline $\mathrm{Sm}$ & $1.00 \mathrm{e}-02$ & $4.00 \mathrm{e}-03$ & $4.00 \mathrm{e}-03$ & $4.00 \mathrm{e}-03$ & $5.00 \mathrm{e}-03$ & $4.00 \mathrm{e}-03$ & $2.00 \mathrm{e}-05$ & $7.00 \mathrm{e}-03$ \\
\hline $\mathrm{Eu}$ & $1.00 \mathrm{e}-02$ & $4.00 \mathrm{e}-03$ & $4.00 \mathrm{e}-03$ & $4.00 \mathrm{e}-03$ & $5.00 \mathrm{e}-03$ & $4.00 \mathrm{e}-03$ & $2.00 \mathrm{e}-05$ & $7.00 \mathrm{e}-03$ \\
\hline $\mathrm{Gd}$ & $1.00 \mathrm{e}-02$ & $4.00 \mathrm{e}-03$ & $4.00 \mathrm{e}-03$ & $4.00 \mathrm{e}-03$ & $3.50 \mathrm{e}-03$ & $4.00 \mathrm{e}-03$ & $2.00 \mathrm{e}-05$ & $7.00 \mathrm{e}-03$ \\
\hline Ho & $1.00 \mathrm{e}-02$ & $4.00 \mathrm{e}-03$ & $4.00 \mathrm{e}-03$ & $4.00 \mathrm{e}-03$ & $4.50 \mathrm{e}-03$ & $4.00 \mathrm{e}-03$ & $2.00 \mathrm{e}-05$ & $7.00 \mathrm{e}-03$ \\
\hline
\end{tabular}


Table A3.4 Dose Conversion Factors (from Eckerman and Ryman, 1993; Eckerman et al., 1989)

\begin{tabular}{|c|c|c|c|c|c|}
\hline Nuclide & $\begin{array}{c}\text { Inhalation DF } \\
(\mathrm{Sv} / \mathrm{Bq})\end{array}$ & $\begin{array}{c}\text { Gas Inhalation DF } \\
(\mathrm{Sv} / \mathrm{Bq})\end{array}$ & $\begin{array}{c}\text { Air Immersion DF } \\
\left(\mathrm{Sv} / \mathrm{s} \text { per } \mathrm{Bq} / \mathrm{m}^{3}\right)\end{array}$ & $\begin{array}{c}\text { Ingestion DF } \\
(\mathrm{Sv} / \mathrm{Bq})\end{array}$ & $\begin{array}{c}\text { External DF } \\
\left(\mathrm{Sv} / \mathrm{s} \text { per } \mathrm{Bq} / \mathrm{m}^{3}\right) 15 \mathrm{~cm}\end{array}$ \\
\hline${ }^{3} \mathrm{H}$ & $1.73 \mathrm{e}-11$ & $2.59 \mathrm{e}-11$ & $3.310 \mathrm{e}-19$ & $1.73 \mathrm{e}-11$ & $0.00 \mathrm{e}+00$ \\
\hline${ }^{10} \mathrm{Be}$ & $9.58 \mathrm{e}-08$ & $0.00 \mathrm{e}+00$ & $1.120 \mathrm{e}-17$ & $1.26 \mathrm{e}-09$ & $5.67 \mathrm{e}-21$ \\
\hline${ }^{14} \mathrm{C}$ & $5.64 \mathrm{e}-10$ & $6.36 \mathrm{e}-12$ & $2.240 \mathrm{e}-19$ & $5.64 \mathrm{e}-10$ & $7.20 \mathrm{e}-23$ \\
\hline${ }^{26} \mathrm{Al}$ & $2.15 \mathrm{e}-08$ & $0.00 \mathrm{e}+00$ & $1.360 \mathrm{e}-13$ & $3.94 \mathrm{e}-09$ & $7.73 \mathrm{e}-17$ \\
\hline${ }^{36} \mathrm{Cl}$ & $6.06 \mathrm{e}-10$ & $0.00 \mathrm{e}+00$ & $2.230 \mathrm{e}-17$ & $8.18 \mathrm{e}-10$ & $1.22 \mathrm{e}-20$ \\
\hline${ }^{39} \mathrm{Ar}$ & $0.00 \mathrm{e}+00$ & $0.00 \mathrm{e}+00$ & $9.100 \mathrm{e}-18$ & $0.00 \mathrm{e}+00$ & $0.00 \mathrm{e}+00$ \\
\hline${ }^{401} \mathrm{~K}$ & $3.34 \mathrm{e}-09$ & $0.00 \mathrm{e}+00$ & $8.050 \mathrm{e}-15$ & $5.02 \mathrm{e}-09$ & $4.57 \mathrm{e}-18$ \\
\hline${ }^{41} \mathrm{Ca}$ & $3.64 \mathrm{e}-10$ & $0.00 \mathrm{e}+00$ & $0.00 \mathrm{e}+00$ & $3.44 \mathrm{e}-10$ & $0.00 \mathrm{e}+00$ \\
\hline${ }^{57} \mathrm{Ni}$ & $2.48 \mathrm{e}-10$ & $0.00 \mathrm{e}+00$ & $0.00 \mathrm{e}+00$ & $5.67 \mathrm{e}-11$ & $0.00 \mathrm{e}+00$ \\
\hline${ }^{6.3} \mathrm{Ni}$ & $6.22 \mathrm{e}-10$ & $0.00 \mathrm{e}+00$ & $0.00 \mathrm{e}+00$ & $1.56 \mathrm{e}-10$ & $0.00 \mathrm{e}+00$ \\
\hline${ }^{610} \mathrm{Co}$ & $5.91 \mathrm{e}-08$ & $0.00 \mathrm{e}+00$ & $1.260 \mathrm{e}-13$ & $7.28 \mathrm{e}-09$ & $7.25 \mathrm{e}-17$ \\
\hline${ }^{85} \mathrm{Kr}$ & $0.00 \mathrm{e}+00$ & $0.00 \mathrm{e}+00$ & $1.190 \mathrm{e}-16$ & $0.00 \mathrm{e}+00$ & $0.00 \mathrm{e}+00$ \\
\hline${ }^{79} \mathrm{Se}$ & $2.66 \mathrm{e}-09$ & $0.00 \mathrm{e}+00$ & $3.030 \mathrm{e}-19$ & $2.35 \mathrm{e}-09$ & $9.96 \mathrm{e}-23$ \\
\hline${ }^{87} \mathrm{Rb}$ & $8.74 \mathrm{e}-10$ & $0.00 \mathrm{e}+00$ & $1.820 \mathrm{e}-18^{-}$ & $1.33 \mathrm{e}-09$ & $7.52 \mathrm{e}-22$ \\
\hline${ }^{90} \mathrm{Sr}+\mathrm{D}$ & $6.68 \mathrm{e}-08$ & $0.00 \mathrm{e}+00$ & $1.980 \mathrm{e}-16$ & $4.14 \mathrm{e}-08$ & $1.24 \mathrm{e}-19$ \\
\hline${ }^{93} \mathrm{Zr}$ & $2.25 \mathrm{e}-08$ & $0.00 \mathrm{e}+00$ & $0.00 \mathrm{e}+00$ & $4.48 \mathrm{e}-10$ & $0.00 \mathrm{e}+00$ \\
\hline${ }^{93 \mathrm{~m}} \mathrm{Nb}$ & $7.90 \mathrm{e}-09$ & $0.00 \mathrm{e}+00$ & $4.440 \mathrm{e}-18$ & $1.41 \mathrm{e}-10$ & $5.57 \mathrm{e}-22$ \\
\hline${ }^{94} \mathrm{Nb}$ & $1.12 \mathrm{e}-07$ & $0.00 \mathrm{e}+00$ & $7.700 \mathrm{e}-14$ & $1.93 \mathrm{e}-09$ & $4.53 \mathrm{e}-17$ \\
\hline${ }^{\mathrm{NY}} \mathrm{Tc}$ & $2.25 \mathrm{e}-09$ & $0.00 \mathrm{e}+00$ & $1.620 \mathrm{e}-18$ & $3.95 \mathrm{e}-10$ & $6.70 \mathrm{e}-22$ \\
\hline${ }^{167} \mathrm{Pd}$ & $3.45 \mathrm{e}-09$ & $0.00 \mathrm{e}+00$ & $0.00 \mathrm{e}+00$ & $4.04 \mathrm{e}-11$ & $0.00 \mathrm{e}+00$ \\
\hline${ }^{113} \mathrm{Cd}$ & $4.51 \mathrm{e}-07$ & $0.00 \mathrm{e}+00$ & $1.450 \mathrm{e}-18$ & $4.70 \mathrm{e}-08$ & $6.05 \mathrm{e}-22$ \\
\hline${ }^{113 \mathrm{~m}} \mathrm{Cd}$ & $4.13 \mathrm{e}-07$ & $0.00 \mathrm{e}+00$ & $6.940 \mathrm{e}-18$ & $4.35 \mathrm{e}-08$ & $3.42 \mathrm{e}-21$ \\
\hline${ }^{121} \mathrm{Sn}$ & $3.11 \mathrm{e}-09$ & $0.00 \mathrm{e}+00$ & $6.020 \mathrm{e}-17$ & $4.19 \mathrm{e}-10$ & $1.05 \mathrm{e}-20$ \\
\hline${ }^{126} \mathrm{Sn}+\mathrm{D}$ & $2.38 \mathrm{e}-08$ & $0.00 \mathrm{e}+00$ & $9.630 \mathrm{e}-14$ & $5.70 \mathrm{e}-09$ & $5.66 \mathrm{e}-17$ \\
\hline${ }^{129} \mathbf{I}$ & $4.69 \mathrm{e}-08$ & $0.00 \mathrm{e}+00$ & $3.800 \mathrm{e}-16$ & $7.46 \mathrm{e}-08$ & $6.93 \mathrm{e}-20$ \\
\hline${ }^{135} \mathrm{Cs}$ & $1.23 \mathrm{e}-09$ & $0.00 \mathrm{e}+00$ & $5.650 \mathrm{e}-19$ & $1.91 \mathrm{e}-09$ & $2.05 \mathrm{e}-22$ \\
\hline${ }^{137} \mathrm{Cs}+\mathrm{D}$ & $8.63 \mathrm{e}-09$ & $0.00 e+00$ & $2.730 \mathrm{e}-14$ & $1.35 \mathrm{e}-08$ & $1.62 \mathrm{e}-17$ \\
\hline${ }^{133} \mathrm{Ba}$ & $2.11 \mathrm{e}-09$ & $0.00 \mathrm{e}+00$ & $1.780 \mathrm{e}-14$ & $9.19 \mathrm{e}-10$ & $9.88 \mathrm{e}-18$ \\
\hline${ }^{151} \mathrm{Sm}$ & $8.10 \mathrm{e}-09$ & $0.00 \mathrm{e}+00$ & $3.610 \mathrm{e}-20$ & $1.05 \mathrm{e}-10$ & $5.27 \mathrm{e}-24$ \\
\hline${ }^{150} \mathrm{Eu}$ & $7.25 \mathrm{e}-08$ & $0.00 \mathrm{e}+00$ & $7.170 \mathrm{e}-14$ & $1.72 \mathrm{e}-09$ & $4.18 \mathrm{e}-17$ \\
\hline${ }^{152} \mathrm{Eu}$ & $5.97 \mathrm{e}-08$ & $0.00 \mathrm{e}+00$ & $5.650 \mathrm{e}-14$ & $1.75 \mathrm{e}-09$ & $3.22 \mathrm{e}-17$ \\
\hline${ }^{152} \mathrm{Gd}$ & $6.58 \mathrm{e}-05$ & $0.00 \mathrm{e}+00$ & $0.00 \mathrm{e}+00$ & $4.34 \mathrm{e}-08$ & $0.00 \mathrm{e}+00$ \\
\hline${ }^{154} \mathrm{Eu}$ & $7.73 \mathrm{e}-08$ & $0.00 \mathrm{e}+00$ & $6.140 \mathrm{e}-14$ & $2.58 \mathrm{e}-09$ & $3.52 \mathrm{e}-17$ \\
\hline${ }^{166} \mathrm{Ho}$ & $8.48 \mathrm{e}-10$ & $0.00 \mathrm{e}+00$ & $1.420 \mathrm{e}-15$ & $1.51 \mathrm{e}-09$ & $7.18 \mathrm{e}-19$ \\
\hline${ }^{216} \mathrm{~Pb}+\mathrm{D}$ & $6.26 \mathrm{e}-06$ & $0.00 \mathrm{e}+00$ & $8.970 \mathrm{e}-17$ & $1.97 \mathrm{e}-06$ & $3.19 \mathrm{e}-20$ \\
\hline${ }^{2017} \mathrm{Bi}$ & $5.41 \mathrm{e}-09$ & $0.00 \mathrm{e}+00$ & $7.540 \mathrm{e}-14$ & $1.48 \mathrm{e}-09$ & $4.34 \mathrm{e}-17$ \\
\hline${ }^{226} \mathrm{R} a+\mathrm{D}$ & $2.32 \mathrm{e}-06$ & $0.00 \mathrm{e}+00$ & $8.860 \mathrm{e}-14$ & $3.58 \mathrm{e}-07$ & $5.05 \mathrm{e}-17$ \\
\hline${ }^{228} \mathrm{Ra}+\mathrm{D}$ & $1.37 \mathrm{e}-06$ & $0.00 \mathrm{e}+00$ & $4.780 \mathrm{e}-14$ & $3.89 \mathrm{e}-07$ & $2.76 \mathrm{e}-17$ \\
\hline${ }^{227} \mathrm{Ac}+\mathrm{D}$ & $1.82 \mathrm{e}-03$ & $0.00 \mathrm{e}+00$ & $1.850 \mathrm{e}-14$ & $3.99 \mathrm{e}-06$ & $1.01 \mathrm{e}-17$ \\
\hline${ }^{228} \mathrm{Th}+\mathrm{D}$ & $9.32 \mathrm{e}-05$ & $0.00 \mathrm{e}+00$ & $8.030 \mathrm{e}-14$ & $2.18 \mathrm{e}-07$ & $4.41 \mathrm{e}-17$ \\
\hline${ }^{229} \mathrm{Th}+\mathrm{D}$ & $4.71 \mathrm{e}-04$ & $0.00 \mathrm{e}+00$ & $1.500 \mathrm{e}-14$ & $1.09 \mathrm{e}-06$ & $7.90 \mathrm{e}-18$ \\
\hline${ }^{2311} \mathrm{Th}$ & $7.07 \mathrm{e}-05$ & $0.00 \mathrm{e}+00$ & $1.740 \mathrm{e}-17$ & $1.48 \mathrm{e}-07$ & $6.39 \mathrm{e}-21$ \\
\hline${ }^{232} \mathrm{Th}$ & $3.11 \mathrm{e}-04$ & $0.00 \mathrm{e}+00$ & $8.720 e-18$ & $7.38 \mathrm{e}-07$ & $2.78 \mathrm{e}-21$ \\
\hline${ }^{23} \mathrm{~Pa}$ & $2.32 \mathrm{e}-04$ & $0.00 \mathrm{e}+00$ & $1.720 \mathrm{e}-15$ & $2.86 \mathrm{e}-06$ & $9.62 \mathrm{e}-19$ \\
\hline${ }^{232} \mathrm{U}$ & $1.78 \mathrm{e}-04$ & $0.00 \mathrm{e}+00$ & $1.420 \mathrm{e}-17$ & $3.54 \mathrm{e}-07$ & $4.77 \mathrm{e}-21$ \\
\hline
\end{tabular}


Table A3.4 (continued)

\begin{tabular}{|c|c|c|c|c|c|}
\hline Nuclide & $\begin{array}{c}\text { Inhalation DF } \\
(\mathrm{Sv} / \mathrm{Bq})\end{array}$ & $\begin{array}{c}\text { Gas Inhalation DF } \\
(\mathrm{Sv} / \mathrm{Bq})\end{array}$ & $\begin{array}{c}\text { Air Immersion DF } \\
\left(\mathrm{Sv} / \mathrm{s} \text { per } \mathrm{B} q / \mathrm{m}^{3}\right)\end{array}$ & $\begin{array}{c}\text { Ingestion DF } \\
(\mathrm{Sv} / \mathbf{B q})\end{array}$ & $\begin{array}{c}\text { External DF } \\
\left(\mathrm{Sv} / \mathrm{s} \text { per } \mathrm{Bq} / \mathrm{m}^{3}\right) 15 \mathrm{~cm}\end{array}$ \\
\hline${ }^{233} \mathrm{U}$ & $3.66 \mathrm{e}-05$ & $0.00 \mathrm{e}+00$ & $1.630 \mathrm{e}-17$ & $7.81 \mathrm{e}-08$ & $7.24 \mathrm{e}-21$ \\
\hline${ }^{2: 4} \mathrm{U}$ & $3.58 \mathrm{e}-05$ & $0.00 \mathrm{e}+00$ & $7.630 \mathrm{e}-18$ & $7.66 \mathrm{e}-08$ & $2.14 \mathrm{e}-21$ \\
\hline${ }^{235} \mathrm{U}+\mathrm{D}$ & $3.32 \mathrm{e}-05$ & $0.00 \mathrm{e}+00$ & $7.720 \mathrm{e}-15$ & $7.23 \mathrm{e}-08$ & $3.94 \mathrm{e}-18$ \\
\hline${ }^{29.6} \mathrm{U}$ & $3.39 \mathrm{e}-05$ & $0.00 \mathrm{e}+00$ & $5.010 \mathrm{e}-18$ & $7.26 \mathrm{e}-08$ & $1.14 \mathrm{e}-21$ \\
\hline${ }^{238} U+D$ & $3.20 \mathrm{e}-05$ & $0.00 \mathrm{e}+00$ & $1.210 \mathrm{e}-15$ & $7.25 \mathrm{e}-08$ & $6.36 \mathrm{e}-19$ \\
\hline${ }^{237} \mathrm{~Np}+\mathrm{D}$ & $1.46 \mathrm{e}-04$ & $0.00 \mathrm{e}+00$ & $1.040 \mathrm{e}-14$ & $1.20 \mathrm{e}-06$ & $5.58 \mathrm{e}-18$ \\
\hline${ }^{238} \mathrm{Pu}$ & $7.79 \mathrm{e}-05$ & $0.00 \mathrm{e}+00$ & $4.880 \mathrm{e}-18$ & $1.34 \mathrm{e}-08$ & $8.07 \mathrm{e}-22$ \\
\hline${ }^{239} \mathrm{Pu}$ & $8.33 e-05$ & $0.00 \mathrm{e}+00$ & $4.240 \mathrm{e}-18$ & $1.40 \mathrm{e}-08$ & $1.52 \mathrm{e}-21$ \\
\hline${ }^{240} \mathrm{Pu}$ & $8.33 \mathrm{e}-05$ & $0.00 \mathrm{e}+00$ & $4.750 \mathrm{e}-18$ & $1.40 \mathrm{e}-08$ & $7.84 \mathrm{e}-22$ \\
\hline${ }^{241} \mathrm{Pu}$ & $1.34 \mathrm{c}-06$ & $0.00 \mathrm{e}+00$ & $7.250 \mathrm{e}-20$ & $2.07 \mathrm{e}-10$ & $3.15 \mathrm{e}-23$ \\
\hline${ }^{242} \mathrm{Pu}$ & $7.92 \mathrm{e}-05$ & $0.00 \mathrm{e}+00$ & $4.010 \mathrm{e}-18$ & $1.33 \mathrm{e}-08$ & $6.85 \mathrm{e}-22$ \\
\hline${ }^{244} \mathrm{Pu}+\mathrm{D}$ & $7.82 \mathrm{e}-05$ & $0.00 \mathrm{e}+00$ & $1.630 \mathrm{e}-14$ & $1.70 \mathrm{e}-08$ & $9.54 \mathrm{e}-18$ \\
\hline${ }^{241} \mathrm{Am}$ & $1.20 \mathrm{e}-04$ & $0.00 \mathrm{e}+00$ & $8.180 \mathrm{e}-16$ & $9.84 \mathrm{e}-07$ & $2.34 \mathrm{e}-19$ \\
\hline${ }^{243} \mathrm{Am}+\mathrm{D}$ & $1.19 \mathrm{e}-04$ & $0.00 \mathrm{e}+00$ & $9.870 \mathrm{e}-15$ & $9.80 \mathrm{e}-07$ & $4.66 \mathrm{e}-18$ \\
\hline${ }^{242} \mathrm{Cm}$ & $4.67 \mathrm{e}-06$ & $0.00 \mathrm{e}+00$ & $5.690 \mathrm{e}-18$ & $3.10 \mathrm{e}-08$ & $9.07 \mathrm{e}-22$ \\
\hline${ }^{24.3} \mathrm{Cm}$ & $8.30 \mathrm{e}-05$ & $0.00 \mathrm{e}+00$ & $5.880 \mathrm{e}-15$ & $6.79 \mathrm{e}-07$ & $3.02 \mathrm{e}-18$ \\
\hline${ }^{244} \mathrm{Cm}$ & $6.70 \mathrm{e}-05$ & $0.00 \mathrm{e}+00$ & $4.910 \mathrm{e}-18$ & $5.45 \mathrm{e}-07$ & $6.74 \mathrm{e}-22$ \\
\hline${ }^{245} \mathrm{Cm}$ & $1.23 \mathrm{e}-04$ & $0.00 \mathrm{e}+00$ & $3.960 \mathrm{e}-15$ & $1.01 \mathrm{e}-06$ & $1.80 \mathrm{e}-18$ \\
\hline${ }^{246} \mathrm{Cm}$ & $1.22 \mathrm{e}-04$ & $0.00 \mathrm{e}+00$ & $4.460 \mathrm{e}-18$ & $1.00 \mathrm{e}-06$ & $6.22 \mathrm{e}-22$ \\
\hline${ }^{247} \mathrm{Cm}+\mathrm{D}$ & $1.12 \mathrm{e}-04$ & $0.00 \mathrm{e}+00$ & $1.600 \mathrm{e}-14$ & $9.24 \mathrm{e}-07$ & $9.22 \mathrm{e}-18$ \\
\hline${ }^{248} \mathrm{Cm}$ & $4.47 \mathrm{e}-04$ & $0.00 \mathrm{e}+00$ & $3.390 \mathrm{e}-18$ & $3.68 \mathrm{e}-06$ & $4.70 e-22$ \\
\hline
\end{tabular}


Table A3.5 Mean and Standard Deviation of the SDCFs for Soil

\begin{tabular}{|c|c|c|c|}
\hline Nuclide & Mean SDCF & S. Dev. & mrem/yr per unit below \\
\hline${ }^{14} \mathrm{C}$ & $6.23 \mathrm{e} 9$ & $3.02 \mathrm{e} 9$ & $\mathrm{Ci} / \mathrm{g}$ soil \\
\hline${ }^{36} \mathrm{Cl}$ & $7.96 \mathrm{e} 11$ & $4.19 \mathrm{e} 11$ & $\mathrm{Ci} / \mathrm{g}$ soil \\
\hline${ }^{40} \mathrm{~K}$ & $3.65 \mathrm{e} 11$ & $7.45 \mathrm{e} 10$ & $\mathrm{Ci} / \mathrm{g}$ soil \\
\hline${ }^{41} \mathrm{Ca}$ & $3.45 \mathrm{e} 9$ & $1.77 \mathrm{e} 9$ & $\mathrm{Ci} / \mathrm{g}$ soil \\
\hline${ }^{91} \mathrm{Sr}+\mathrm{D}$ & $3.76 \mathrm{e} 11$ & $2.06 \mathrm{e} 11$ & $\mathrm{Ci} / \mathrm{g}$ soil \\
\hline${ }^{94} \mathrm{Nb}$ & $3.20 \mathrm{e} 12$ & $7.04 \mathrm{e} 11$ & Ci/g soil \\
\hline${ }^{99} \mathrm{Tc}$ & $4.79 \mathrm{e} 10$ & $1.99 \mathrm{e} 10$ & $\mathrm{Ci} / \mathrm{g}$ soil \\
\hline${ }^{126} \mathrm{Sn}$ & $4.01 \mathrm{e} 12$ & $8.79 \mathrm{e} 11$ & $\mathrm{Ci} / \mathrm{g}$ soil \\
\hline${ }^{137} \mathrm{Cs}+\mathrm{D}$ & $1.17 \mathrm{e} 12$ & $2.52 \mathrm{e} 11$ & $\mathrm{Ci} / \mathrm{g}$ soil \\
\hline${ }^{210} \mathrm{~Pb}+\mathrm{D}$ & $8.34 \mathrm{e} 11$ & $3.67 \mathrm{el} 1$ & $\mathrm{Ci} / \mathrm{g}$ soil \\
\hline${ }^{226} \mathrm{Ra}+\mathrm{D}$ & $3.73 \mathrm{e} 12$ & $7.89 \mathrm{e} 11$ & $\mathrm{Ci} / \mathrm{g}$ soil \\
\hline${ }^{22 \times} \mathrm{Ra}+\mathrm{D}$ & $2.13 \mathrm{e} 12$ & $4.38 \mathrm{e} 11$ & $\mathrm{Ci} / \mathrm{g}$ soil \\
\hline${ }^{227} \mathrm{Ac}+\mathrm{D}$ & $4.16 \mathrm{e} 12$ & $7.95 \mathrm{e} 11$ & $\mathrm{Ci} / \mathrm{g}$ soil \\
\hline${ }^{228} \mathrm{Th}+\mathrm{D}$ & $3.30 \mathrm{e} 12$ & $6.87 \mathrm{e} 11$ & $\mathrm{Ci} / \mathrm{g}$ soil \\
\hline${ }^{229} \mathrm{Th}+\mathrm{D}$ & $1.47 \mathrm{e} 12$ & $2.43 \mathrm{e} 11$ & $\mathrm{Ci} / \mathrm{g}$ soil \\
\hline${ }^{230} \mathrm{Th}$ & $1.33 \mathrm{e} 11$ & $2.95 \mathrm{e} 10$ & $\mathrm{Ci} / \mathrm{g}$ soil \\
\hline${ }^{212} \mathrm{Th}$ & $6.08 \mathrm{e} 11$ & $1.40 \mathrm{e} 11$ & $\mathrm{Ci} / \mathrm{g}$ soil \\
\hline${ }^{231} \mathrm{~Pa}$ & $1.21 \mathrm{e} 12$ & $4.25 \mathrm{e} 11$ & $\mathrm{Ci} / \mathrm{g}$ soil \\
\hline${ }^{233} \mathrm{U}$ & $8.78 \mathrm{e} 10$ & $2.06 \mathrm{e} 10$ & $\mathrm{Ci} / \mathrm{g}$ soil \\
\hline${ }^{2: 34} \mathrm{U}$ & $8.56 \mathrm{e} 10$ & $2.02 \mathrm{e} 10$ & $\mathrm{Ci} / \mathrm{g}$ soil \\
\hline${ }^{233} \mathrm{U}+\mathrm{D}$ & $3.59 \mathrm{e} 11$ & $6.42 \mathrm{e} 10$ & Ci/g soil \\
\hline${ }^{236} \mathrm{U}$ & $8.11 \mathrm{e} 10$ & $1.92 \mathrm{e} 10$ & $\mathrm{Ci} / \mathrm{g}$ soil \\
\hline${ }^{238} U+D$ & $1.24 \mathrm{e} 11$ & $2.14 \mathrm{e} 10$ & $\mathrm{Ci} / \mathrm{g}$ soil \\
\hline${ }^{237} \mathrm{~Np}+\mathrm{D}$ & $1.08 \mathrm{e} 12$ & $2.76 \mathrm{ell}$ & $\mathrm{Ci} / \mathrm{g}$ soil \\
\hline${ }^{238} \mathrm{Pu}$ & $1.00 \mathrm{e} 11$ & $2.16 \mathrm{e} 10$ & $\mathrm{Ci} / \mathrm{g}$ soil \\
\hline${ }^{239} \mathrm{Pu}$ & $1.07 \mathrm{e} 11$ & $2.31 \mathrm{e} 10$ & $\mathrm{Ci} / \mathrm{g}$ soil \\
\hline${ }^{240} \mathrm{Pu}$ & $1.07 \mathrm{e} 11$ & $2.31 \mathrm{e} 10$ & $\mathrm{Ci} / \mathrm{g}$ soil \\
\hline${ }^{24} 1 \mathrm{Pu}$ & $1.72 \mathrm{e} 9$ & $3.71 \mathrm{e} 8$ & $\mathrm{Ci} / \mathrm{g}$ soil \\
\hline${ }^{241} \mathrm{Am}$ & $4.57 \mathrm{e} 11$ & $1.48 \mathrm{e} 11$ & $\mathrm{Ci} / \mathrm{g}$ soil \\
\hline
\end{tabular}

Table A3.6 Mean and Standard Deviation of the SDCFs for Nonvolatile and Volatile Radionuclides in Air

\begin{tabular}{c|c|c|c}
\hline Nuclide & Mean PDCF & S. Dev. & mrem/yr per unit below \\
\hline & \multicolumn{3}{c}{ Nonvolatile Radionuclides } \\
\hline${ }^{14} \mathrm{C}$ & $9.05 \mathrm{e} 9$ & $1.19 \mathrm{e} 9$ & $\mathrm{Ci} / \mathrm{m}^{3}$ air \\
\hline${ }^{36} \mathrm{Cl}$ & $9.72 \mathrm{e} 9$ & $1.27 \mathrm{e} 9$ & $\mathrm{Ci} / \mathrm{m}^{3}$ air \\
\hline${ }^{40} \mathrm{~K}$ & $5.36 \mathrm{e} 10$ & $7.02 \mathrm{e} 9$ & $\mathrm{Ci} / \mathrm{m}^{3}$ air \\
\hline${ }^{90} \mathrm{Sr}+\mathrm{D}$ & $1.07 \mathrm{e} 12$ & $1.40 \mathrm{e} 11$ & $\mathrm{Ci} / \mathrm{m}^{3}$ air \\
\hline${ }^{94} \mathrm{Nb}$ & $1.80 \mathrm{e} 12$ & $2.35 \mathrm{e} 11$ & $\mathrm{Ci} / \mathrm{m}^{3}$ air \\
\hline${ }^{49} \mathrm{Tc}$ & $3.61 \mathrm{e} 10$ & $4.73 \mathrm{e} 9$ & $\mathrm{Ci} / \mathrm{m}^{3}$ air \\
\hline${ }^{126} \mathrm{Sn}$ & $3.82 \mathrm{e} 11$ & $5.00 \mathrm{e} 10$ & $\mathrm{Ci} / \mathrm{m}^{3}$ air \\
\hline${ }^{137} \mathrm{Cs}+\mathrm{D}$ & $1.38 \mathrm{e} 11$ & $1.81 \mathrm{el} 10$ & $\mathrm{Ci} / \mathrm{m}^{3}$ air \\
\hline${ }^{216} \mathrm{~Pb}+\mathrm{D}$ & $1.00 \mathrm{e} 14$ & $1.32 \mathrm{e} 13$ & $\mathrm{Ci} / \mathrm{m}^{3}$ air \\
\hline${ }^{226} \mathrm{Ra}+\mathrm{D}$ & $3.72 \mathrm{e} 13$ & $4.88 \mathrm{e} 12$ & $\mathrm{Ci} / \mathrm{m}^{3}$ air \\
\hline${ }^{228} \mathrm{Ra}+\mathrm{D}$ & $2.20 \mathrm{e} 13$ & $2.88 \mathrm{e} 12$ & $\mathrm{Ci} / \mathrm{m}^{3}$ air \\
\hline
\end{tabular}


Table 3.6 (continued)

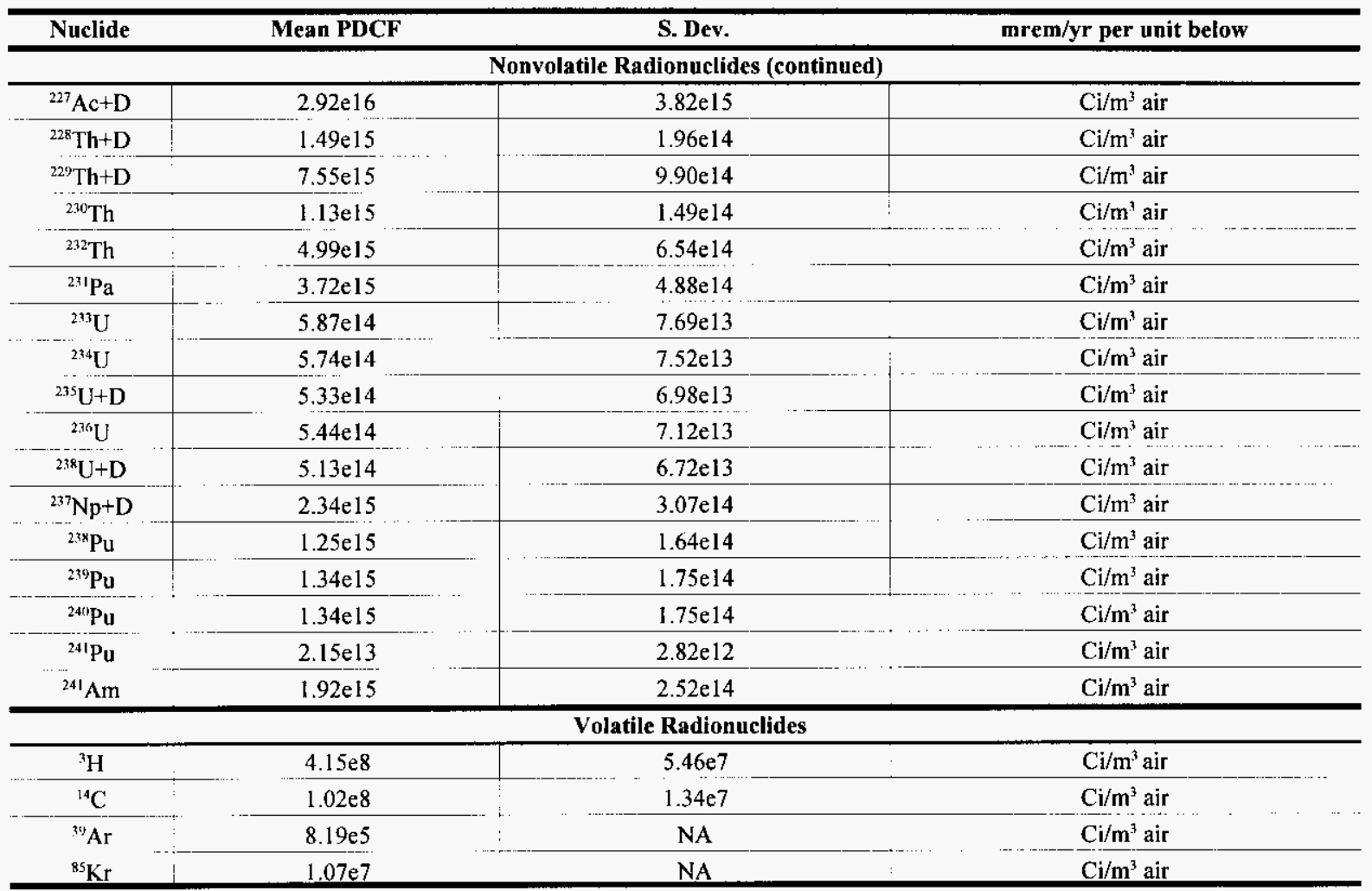

NA - Not available; fixed value assumed.

Indoor mass loading was calculated as the product of the indoor soil loading and the resuspension factor. The distribution is assumed to be triangular. While indoors, residents are assumed to be exposed to the outdoor mass loading plus the indoor mass loading. The indoor and outdoor mass loading factors were assumed to be correlated with a correlation coefficient of 1.0.

Mass loading while gardening is very dependent on the activity being performed and the properties of the soil. A value of $5 \mathrm{e}-4 \mathrm{~g} / \mathrm{m}^{3}$ is commonly recommended for radiological assessment (Nuclear Regulatory Commission [NRC], 1981; Kennedy and Strenge, 1992). This is considered a conservative upper limit. The parameter is assumed to vary uniformly between a high background level of $1 \mathrm{e}-4 \mathrm{~g} / \mathrm{m}^{3}$ and an upper limit of $5 \mathrm{e}-4 \mathrm{~g} / \mathrm{m}^{3}$.

Ventilation rates are selected based on assumed physical activity levels for each time period. The ventilation rates for various activity levels have been estimated by Layton (1993), based on metabolic oxygen requirements. The distributions are assumed to be uniform, with ranges bracketing the reported ventilation rate for the assumed level of physical activity. The sleeping period assumes a resting ventilation rate, the indoor period assumes a sedentary ventilation rate, the outdoor ventilation rate assumes light activity, and the gardening period assumes moderate to heavy work. The ventilation rates are assumed to be correlated with a correlation coefficient of 1.0 . 
The scenarios assume that the resident commutes to a remote work location. The resident is assumed to spend 2,000 hours per year at work and a fixed 8 hours per day sleeping in the residence, or 2,922 hours per year. All remaining time is assumed to be spent at the residence. Surveys of activity patterns of adults have suggested that most individuals are outside from 5 to 40 percent of the time that they are at home (Layton et al., 1993; and National Council on Radiation Protection [NCRP], 1984). Therefore, the time spent indoors is assumed to vary uniformly between 60 and 95 percent of the total time at home. The time spent outdoors is calculated as the remaining time. The resident is assumed to spend a fixed time of 100 hours per year in the garden.

\section{A3.1.5.2 Gas Inhalation Pathway}

All parameters for the gas inhalation pathway are the same as in the soil inhalation pathway, except for the dose conversion factors.

\section{A3.1.5.3 Air Immersion Pathway}

All parameters for the air immersion pathway are the same as in the soil inhalation pathway, except for the dose conversion factors.

\section{A3.1.5.4 External Irradiation Pathway}

All parameters for the external irradiation pathway common with the soil inhalation pathway are unchanged, except for the dose conversion factors. Members of the public are assumed to be 100 meters $(\mathrm{m})(330$ feet $[\mathrm{ft}])$ from the site. The scenarios assume an external DF for a $0.15-\mathrm{m}-$ $(0.50-\mathrm{ft})$-thick contaminated soil layer. The soil bulk density is assumed to be $1.6 \mathrm{~g} / \mathrm{cm}^{3}$ as required by the dose conversion factor.

The transmission factor is assumed to be fixed at 1.0 for all time periods spent outdoors. Transmission factors for indoor occupancy are dependent on the construction materials used in the residence and its design. Transmission factors for one-story residences have been reported to range from 0.06 to 0.27 (NCRP, 1984). Motor vehicles, which may approximate a mobile home, have been reported to have factors ranging from 0.15 to 0.6 (NCRP, 1984). Kennedy and Strenge (1992) recommend 0.33 as a representative value for a residence. The indoor transmission factor is assumed to be triangular, with a mode of 0.33 and a range from 0.06 to 0.6 .

\section{A3.1.5.5 Inadvertent Soil Ingestion Pathway}

Adults have been reported to ingest from 0.005 to $0.077 \mathrm{~g} /$ day of soil (Kennedy and Strenge, 1992). A value of $0.05 \mathrm{~g} /$ day has been reported as a representative mean value. Accordingly, the distribution is assumed to be triangular with a mode of $0.05 \mathrm{~g} / \mathrm{day}$ and range from 0.005 to $0.077 \mathrm{~g} /$ day. 


\section{A3.1.5.6 Agricultural Pathways}

Based on current land use in southern Nevada, the occurrence of agriculture at the Area 5 RWMS is expected to be a low-probability event. All agricultural parameters are assigned fixed parameter values, except for the fraction of the diet that is produced in the contaminated area. The scenario assumes that the resident or the intruder works full time at a remote location and is therefore not engaged in agriculture on a full-time basis. Gardening or livestock production in Frenchman Flat would be difficult. However, production of home-grown vegetables and fruits does occur in areas surrounding the NTS (EPA, 1984). Intense sunlight, arid conditions, infertile soil, and extreme temperatures make cultivation of some crops infeasible or shortens the growing season for others. Therefore, the resident is assumed to engage in small-scale, noncommercial agriculture at the site because of the poor conditions and limited time spent on site.

The resident is assumed to cultivate a small vegetable garden. Regional data on the production of home-grown vegetables are not available. The EPA (1989) has suggested that individuals cultivating a home garden typically produce 20 percent of their vegetable intake. Given the difficulties of vegetable gardening in southern Nevada, the typical vegetable production is assumed to be an upper limit for this site. A 30-square-meter $\left(\mathrm{m}^{2}\right)\left(322\right.$-square-foot $\left.\left[\mathrm{ft}^{2}\right]\right)$ garden plot would be sufficient to support 20 percent of the vegetable intake for a typical household of 2.3 persons. Crops produced are assumed to be limited to leafy vegetables, root crops, and fruits. Production of grains is assumed to be beyond the scope of part-time, noncommercial agriculture.

The plant uptake model uses an effective plant-soil concentration ratio that is the sum of a root uptake factor and a soil mass loading factor. Root uptake plant-soil concentration ratios are listed in Table A3.3. The soil mass loading factor has been estimated as the product of soil mass loading and a translocation factor. Martin and Bloom (1980) have estimated that uptake of Pu by native plants at the NTS is 99 percent attributable to soil deposition. They have reported that the mean plant-soil concentration ratio for 506 paired samples is 0.096 . This concentration ratio is assumed to estimate soil mass loading because root uptake of $\mathrm{Pu}$ is generally insignificant. Assuming a translocation factor of 1.0 for leafy vegetables and forage, and a translocation factor of 0.1 for all other plants (Kennedy and Strenge, 1992), soil mass loading factors of 0.1 and $0.01 \mathrm{~kg}$ dry soil $/ \mathrm{kg}$ dry plant can be assumed.

The resident is also assumed to maintain livestock at the site. Livestock is assumed to include beef cattle and poultry. Milk and eggs from livestock are also assumed to be available. Cultivation of an irrigated hay crop is assumed to be beyond the scope of noncommercial agriculture. Therefore, the cattle and poultry are assumed to have a diet consisting of contaminated natural forage, uncontaminated natural forage, and uncontaminated grain and hay purchased off site. Livestock are assumed to ingest soil while foraging. The area of the contaminated zone is assumed to limit the availability of contaminated forage for cattle. Larrea communities in Frenchman Flat have been estimated to have a grazing capacity of 0.07 animal unit months (AUM) per hectare (ha) (Richard-Haggard, 1983). The contaminated area is assumed to be capable of supporting all the forage requirements of poultry. Residents producing beef and dairy products have been reported to typically produce 40 percent of their 
annual consumption (EPA, 1989). This level of consumption by a household of 2.3 persons can be supported by a single beef cow and nine chickens. This is assumed as an upper limit for this site.

\section{A3.1.6 Model Implementation}

The radiological assessment was implemented on an $\operatorname{Excel}^{\circ}$ (Version 5.0) spreadsheet. Monte Carlo simulations were implemented with the Crystal Ball package (Version 4.0c) (Decisioneering, 1988). The PDCF values are the arithmetic mean of 10,000 Monte Carlo realizations (Tables A3.5 and A3.6).

\section{A3.1.6.1 Uncertainty and Sensitivity of Pathway Dose Factors}

Nine parameters in the nonagricultural pathways are evaluated as random variables. The DFs, perhaps the greatest source of uncertainty in the PDCF, are treated as fixed values. In most cases, the most conservative DFs have been selected. Exceptions are the inhalation DF for ${ }^{36} \mathrm{Cl}$, the inhalation DF for ${ }^{90} \mathrm{Sr}$, and the ingestion and inhalation DFs for Pu isotopes. The DFs were selected based on the chemical form of the inventory. The ${ }^{36} \mathrm{Cl}$ and ${ }^{90} \mathrm{Sr}$ SDCFs are relatively insensitive to the assumptions. Using the most conservative $\mathrm{DF}$ for ${ }^{36} \mathrm{Cl}$ has no effect on the SDCFs. For ${ }^{90} \mathrm{Sr}$, the more conservative inhalation DF has no effect on the SDCFs. The SDCFs are sensitive to the assumed Pu DFs. Using the most conservative lung clearance class (class W) and the intermediate ingestion DF $\left(f_{1}=1 \mathrm{e}-4\right)$ the SDCFs increase by about a factor of 2 . The DFs were chosen to represent a low-fired Pu oxide waste source term, which is consistent with waste derived from weapons production and testing. If the chemical form were to change in the future, the Pu dose could increase at most by a factor of 2 .

The estimated SDCFs generally vary over an order of magnitude range. In most cases, the maximum value of the SDCF is within an order of magnitude of the mean value. The sensitivity of the SDCFs is controlled by the largest DF. Radionuclides with large external irradiation DFs tend to be most sensitive to the indoor transmission factor and the amount of time spent outdoors. Radionuclides with large inhalation DFs tend to be most sensitive to indoor and outdoor mass loading. Radionuclides with large ingestion DFs are most sensitive to the amount of soil inadvertently ingested or the amount of vegetables produced.

\section{A3.1.6.2 Verification and Benchmarking}

The radiological assessment spreadsheet calculations have been verified and benchmarked using the RESRAD 5.61 radiological assessment code. RESRAD is a DOE-supported radiological assessment code used to develop guidelines for cleanup of residual radioactive material ( $\mathrm{Yu}$ et al., 1993). Verification provides assurance that a code performs a specified numerical model. Benchmarking is a comparison with established or previously tested codes and provides a comparison between the results of an accepted code and the spreadsheet for an assumed exposure scenario. Complete details of the verification and benchmarking were reported by Shott et al., (1997). 
Verification tests were generally able to reproduce spreadsheet results to within 1 to 3 percent. Benchmark results for the external irradiation pathways were equivalent to spreadsheet results; benchmark results for the inhalation and soil ingestion pathways were within 3 to 4 percent of the spreadsheet results. The differences were attributable to different DFs. The vegetable and animal product ingestion pathways had the largest differences which were attributable to different DFs, plant-soil concentration ratios, and transfer factors.

\section{A3.2 References}

Amiro, B. D., Y. Zhuang, and S. C. Sheppard, 1991. "Relative Importance of Atmospheric and Root Uptake Pathways for ${ }^{14} \mathrm{CO}_{2}$ Transfer From Contaminated Soil to Plants." Health Physics 61(6):825-829.

Bechtel Nevada, 1997. "Hydrogeologic Characterization of U-3at Collapse Zone: Data Report." January, 1997. Report to U.S. Department of Energy/Nevada Operations Office, Las Vegas, Nevada.

_ 1996a. "Hydrogeologic Characterization of U-3bh Collapse Zone." August 1996. Report to U.S. Department of Energy/Nevada Operations Office, Las Vegas, Nevada.

_ 1996b. "Hydrogeologic Characterization of U-3bl Collapse Zone." November 1996. Report to U.S. Department of Energy/Nevada Operations Office, Las Vegas, Nevada.

Clark County Health District, 1997. Particulate Matter Data for Clark County, Nevada. Personal communication, L. Femi Durosinmi, Air Pollution Control District, Las Vegas, Nevada; to Greg Shott, Bechtel Nevada, July 7, 1997.

Decisioneering, 1988. Crystal Ball User's Manual (Version 4.0). Decisioneering, Denver, Colorado.

Eckerman, K. F., and J. C. Ryman, 1993. External Exposure to Radionuclides in Air, Water, and Soil. Federal Guidance Report 12. U.S. Environmental Protection Agency, Washington, D.C.

Eckerman, K. F., A. B. Wolbarst, and A. C. B. Richarson, 1989. Limiting Values of Radionuclide Intake and Air Concentrations and Dose Conversion Factors for Inhalation, Submersion, and Ingestion. Federal Guidance Report No. 11. U.S. Environmental Protection Agency, Washington, D.C.

EPA, 1989. Exposure Factors Handbook. EPA 600.0-89-043. U.S. Environmental Protection Agency, Washington, D.C.

—_ 1984. Population Distribution Around the Nevada Test Site. EPA-600/4-84-067. Environmental Monitoring Systems Laboratory, Las Vegas, Nevada. 
ICRP, 1979. Limits for Intakes of Radionuclides by Workers, Part 1. ICRP Publication 30. Pergamon Press, New York, New York.

Kennedy, W. E. Jr, and D. L. Strenge, 1992. Residual Radioactive Contamination From Decommissioning, Vol. 1. NUREG/CR-5512. Pacific Northwest Laboratory, Richland, Washington.

Layton, D. W., 1993. "Metabolically Consistent Breathing Rates for Use in Dose Assessments." Health Physics 64(1):23-36.

Layton, D. W., L. R. Anspaugh, K. T. Bogen, and T. Straume, 1993. "Risk Assessment of SoilBased Exposures to Plutonium at Experimental Sites Located on the Nevada Test Site and Adjoining Areas." pp. 19-59. In: J. I. Daniels (ed.), Pilot Risk Assessment for Selected Problems at the Nevada Test Site. UCRL-LR-113891. Lawrence Livermore National Laboratory, Livermore, California.

Martin, W. E., and S. G. Bloom, 1980. "Nevada Applied Ecology Group Model for Estimating Plutonium Transport and Dose to Man." pp 459-512. In: W.C. Hanson (ed.), Transuranic Elements in the Environment. DOE/TIC-22800. Technical Information Center, U.S. Department of Energy, Washington, D.C.

McArthur, R. D., 1991. Radionuclides in Surface Soil at the Nevada Test Site. DOE/NV/10845--02, Publication \#45077. Desert Research Institute, University of Nevada System, Las Vegas, Nevada.

NCRP, 1984. Radiological Assessment: Predicting the Transport, Bioaccumulation, and Uptake by Man of Radionuclides Released to the Environment. NCRP Report 76. NCRP, Bethesda, Maryland.

NRC, 1981. Draft Environmental Impact Statement on 10 CFR Part 61, "Licensing Requirements for Land Disposal of Radioactive Waste." Appendices G-Q. NUREG-0782, Vol. 4. U.S. Nuclear Regulatory Commission, Washington, D.C.

Richard-Haggard, K., 1983. Economic Potential of Alternative Land and Natural Resources at the Nevada Test Site, Nye County, Nevada. Pub. 45030, Water Resources Center, Desert Research Institute, University of Nevada, Las Vegas, Nevada.

Rupp, E. M., 1980. "Age-Dependant Values of Dietary Intake for Assessing Human Exposures to Environmental Pollutants." Health Physics 39:151-163.

Sheppard, M. I., S. C. Sheppard, and B. D. Amiro, 1991. "Mobility and Plant Uptake of Inorganic ${ }^{14} \mathrm{C}$ and ${ }^{14} \mathrm{C}$-Labeled PCB in Soils of High and Low Retention." Health Physics 61(4): 481-492. 
Shinn, J. H., D. N. Homan, and C. B. Hofmann, 1986. A Summary of Plutonium Aerosol Studies: Resuspension at the Nevada Test Site. UCRL-90746. Lawrence Livermore National Laboratory, Livermore, California.

Shinn, J. H, and D. N. Homan, 1985. "Plutonium-Aerosol Emission Rates and Human Pulmonary Deposition Calculations for Nuclear Site 201, Nevada Test Site." pp 261-278. In: W. A. Howard and D. G. Fuller (eds.), The Dynamic of Transuranics and Other Radionuclides in Natural Environments. NVO-272. U.S. Department of Energy/Nevada Operations Office, Las Vegas, Nevada.

Shott, G. J., V. Yucel, M. J. Sully, L. E. Barker, and S. E. Rawlinson, 1997. Performance Assessment/Composite Analysis for the Area 3 Radioactive Waste Management Site at the Nevada Test Site, Nye County, Nevada (Revision 2.0). Bechtel Nevada, Las Vegas, Nevada.

Smith, D. D., 1977. "Grazing Studies on a Contaminated Range of the Nevada Test Site." pp. 139-149. In: M. G. White, P. B. Dunaway, and W. A. Howard (eds.), Environmental Plutonium on the Nevada Test Site and Environs. NVO-171, UC-2. Energy Research and Development Administration, Las Vegas, Nevada.

Wood, D. E., R. U. Curl, D. R. Armstrong, J. R. Cook, M. R. Dolenc, D. C. Kocker, K. W. Owens, E. P. Regnier, G. W. Roles, R. R. Seitz, and M. I. Wood, 1994. Performance Assessment Task Team Progress Report. DOE/LLW-157. Idaho National Engineering Laboratory, Idaho Falls, Idaho.

Yu, C., A. J. Zielen, J. J. Cheng, Y. C. Yuan, L. G. Jones, D. J. LePoire, Y. Y. Wang, C. O. Loureiro, E. Gnanapragasam, E. Faillace, A. Wallo III, W. A. Williams, and H. Peterson, 1993. Manual for Implementing Residual Radioactive Material Guidelines Using RESRAD (Version 5.0). ANL/EAD/LD-2. Argonne National Laboratory, Argonne, Illinois. 